\title{
THE BOOK
}

\author{
OF \\ DUCK DECOYS
}

Sir Ralph Payne-Gallwey

BART. 



$$
\begin{aligned}
& \text { L. H we tadkes } \\
& \text { 2) } 110 / 15
\end{aligned}
$$

$$
\text { O. Wrtmore } \quad z-6
$$

THE

\section{BOOK OF DUCK DECOYS}






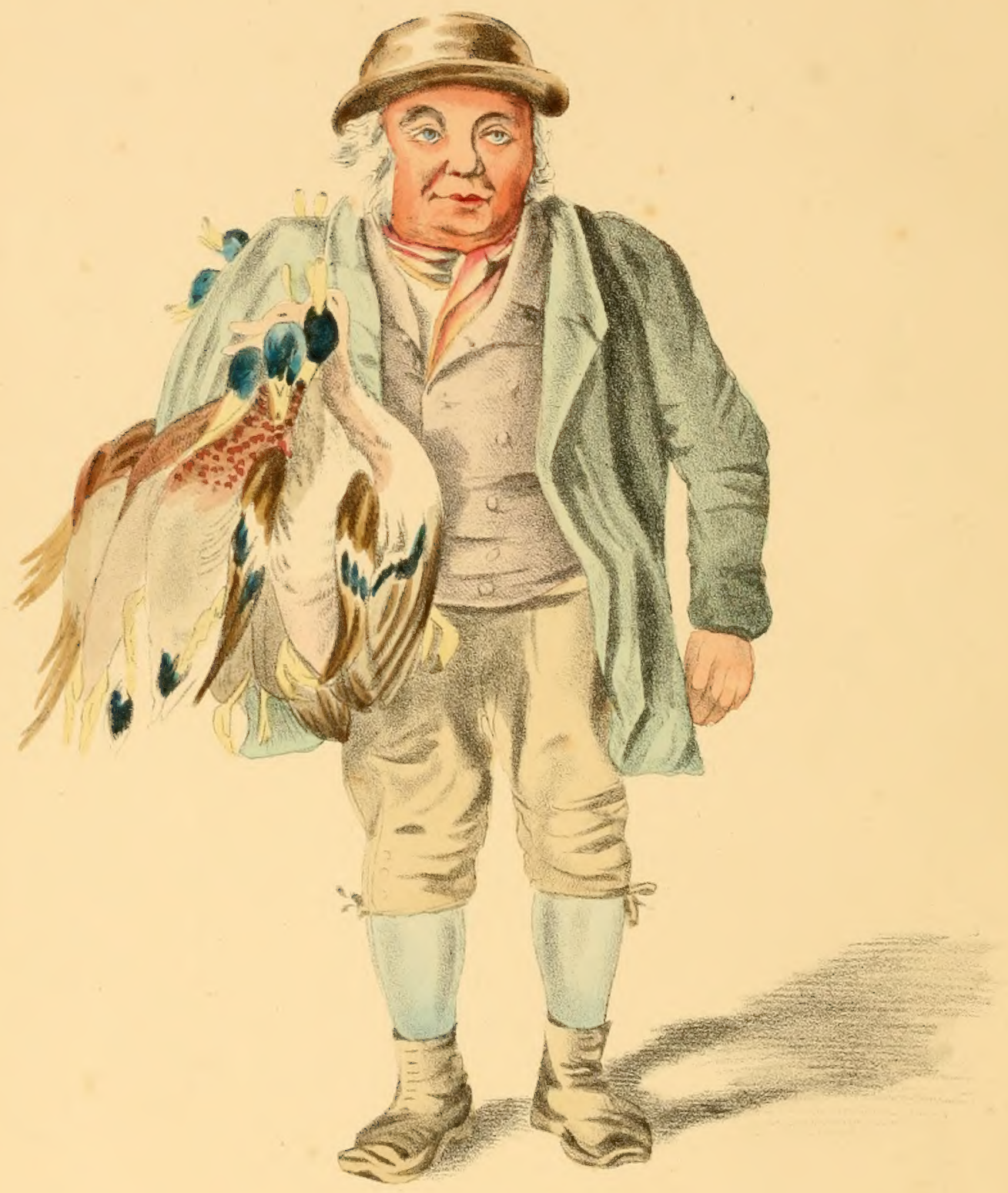

G. SKELTON. 


\section{BOOK OF DUCK DECOYS}

THEIR

\section{CONSTRUCTION, MANAGEMENT, ANI) \\ HISTORY}

Sir RALPH PAYNE-GALLWEY, BART.

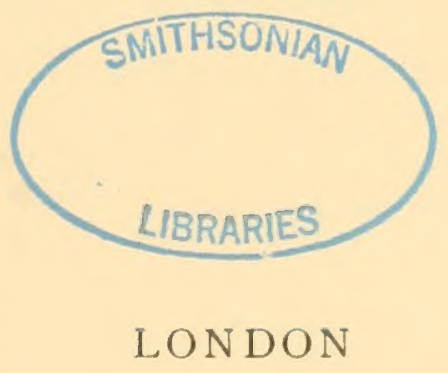

JOHN VAN VOORST, PATERNOSTER ROW MDCCCLXXXVI. 
LONDON :

PKINTED BY WOODFALL AND KINDER, MILFORD LANE, STKAND, W.C. 


\title{
LINES ON ANDREW WILLIAMS,
}

\author{
WHO DIED IN I 776, AGED 84,
}

And who Served the Lloyds of Aston, in Shropshire, for Sixty Years as Decoyman. (Page i5o.)

"Here lies the Decoyman who lived like an otter, Dividing his time betwixt land and water; His hide he oft soaked in the waters of Perry,* Whilst Aston old beer his spirits kept cheery. Amphibious his life, Death was puzzled to say How to dust to reduce such well-moistened clay. So Death turned Decoyman, and 'coyed him to land, Where he fixed his abode till quite dried to the hand. He then found him fitting for crumbling to dust; And here he lies mouldering as you and I must."

\footnotetext{
* The river that passed near the Decoy.
} 



\section{P R E F A C E.}

Ix launching this Book about Decoys, I hope to supply a want and afford information to those who are interested in this special and peculiar branch of Fowling. To the Naturalist and Irildfowler, as well as to the Toposrapher and Antiquarian, I chicfly appeal. But whether the title, one of unknown import probably to nine out of ten people, will attract the attention of Sportsmen at large remains to be proved. My object, con amore, is to place on record the Method of constructing Decoys, as well as the manner of taking Wildfowl therein.

I shall include also all obtainable data and notes connected with the History of Decoys past and present, before such are for ever lost.

With this object in view I have taken much trouble in acquiring all possible information on this sport-one rapidly being forgotten; and one that, for amusement and instruction to all lovers of wild birds, has no equal. That the history of Decoys without some such effort as the present would speedily have been lost, could not fail to be the case, as the old Decoymen die off, and Decoys annually cease to exist.

No book of any kind has yet been published on the subject, and lest none should appear the present work has been undertaken.

It may be an interesting matter of surprise, even to those who have some little knowledge of Decoys, to read of the enormous number of Wilclfowl taken in them in former days, when Decoying was a trale of astonishing dimensions in England, and the capture of Itildfowl was carried on to an extent little suspected of by the present generation.

As an example, I may state that in our Eastern Counties alone there formerly cxisted some roo I ceoys, which, at a moderate estimate for those days, took on an average 5,000 I lucks apiece yearly; in other worts, con- 
tributing to the markets the enormous total of half a million birds, of a purely wild and valuable nature, and this too without firing a shot.

During the last dozen years I have waged constant warfare against Wildfowl, with all imaginable contrivances in the way of yachts, punts, and guns, in various parts of the world, as well as at home, at a cost ofI should be afraid to say how much time and money-yet I can account for but six or seven thousand Ducks. Now, in one winter alone, it was in our grandfathers' days a usual thing for a Decoyman to catch from five to ten thousand birds, at an annual outlay of perhaps $\mathscr{E} 50$ spent in keeping up a pond and its netting, its pipes and its reed screens.

England and Ireland, as well as many parts of Scotland, are still admirably suited for Decoys; not, it is true, as a means of profit as of yore, but as a constant source of amusement. For surely a Decoy, however small it may be, haunted by numbers of beautiful Wildfowl, affords a fund of interesting instruction that may always be resorted to with advantage by both sportsmen and naturalists.

It may be said with confidence, that there is scarcely a park or property in Great Britain where a moderate venture in the shape of a Decoy, costing from $\mathscr{L}$ ioo to $\mathscr{E}$ i 50 , could not be constructed. Its annual cxpense might be $£ 30$ to $£ 40$. Any fairly intelligent keeper could work it well enough to supply its owner claily during the winter with a dainty dish for his table, besides now and again plenty of birds to spare for friendly presents as well.

There may possibly exist some few unworked and almost forgotten Decoys of which I have not heard. Should this be the case, I shall be grateful to know of them, in order, if possible, to rectify such omissions.

\section{Ralph Payne-Galliney.}

THIRKLEBY I'ARK,

THIRSK.

May, I 886. 


\section{SUMMARY OF CONTENTS.}

CHAPTER I.

Decoymen-Derivation of Word Decoy-Origin and Age of Decoys-Driving DucksPACE Works relating to Decoys - The Position of Decoys - The Skeltons-The Law of Decoys-Phraseology of a Decoy-What a Decoy consists of

CHAPTER II.

The System of Catching the Birds when in the Decoy Pipes-The Methods used to Decoy the Ducks into the Pipes-Dogging-Feeding-The Effect of the Food, and of the Dog, on the Ducks-How the Decoyman drives the Birds up the Pipe, both when Dogging and Feeding .

\section{CHAPTER III.}

The Construction of a Decoy-The Pipes-The Hoops-The Netting-The Tunnelnet-The Pond-The Water Supply-The Landings and Banks-Fencing-The Screens-The Tame Decoy Ducks-The Decoy Dog-The Food .

CHAPTER IV.

General Directions in the Management of a Decoy-'The Wind--The Time most suitable for Decoying-Ice-breaking-Killing Birds-Criticism of Decoys illustrated in the Book-Description of a Decoy and a Decoy Pipe, with Folding Plans-A List of Decoys, Past and Present, in the British Islands

CHAPTER V.

A History of Decoys, Past and Present:-Berkshire-Buckinghamshire-Cambridgeshire-Cornwall-Derbyshire-Dorsetshire .

CHAPTER VI.

A History of Decoys, Past and Present (continued) :-Fssex

CHAPTER VII.

A History of Decoys, Past and Present (continued) :-Glamorganshire-Gloucestershire - Hampshire - Herefordshire - Huntingdonshire - Hertfordshire - KentI.ancaster 
CHAPTER VIII.

A History of Decoys, Past and Present (continued) :-Lincolnshire

CHAPTER IX.

A History of Decoys, Past and Present (contimued) :-Middlesex-MonmouthshireMontgomeryshire.

CHAPTER $X$.

A History of Decoys, Past and Present (continued):-Norfolk

\section{CHAPTER XI.}

A History of Decoys, Past and Present (continued) :-Northamptonshire-Nottinghanshire-Oxfordshire-Pembrokeshire-Shropshire . . . . . . . I42

CHAP'TER XII.

A History of Decoys, Past and Present (continued) :--Somerset--Staffordshire . . I52 CHAP'TER XIII.

A History of Decoys, Past and Present (continued) :-Suffolk . . . . . I6r

\section{CHAPTER XIV.}

A History of Decoys, Past and Present (continued):-Surrey-Sussex-Warwickshire-

Westmoreland-Wiltshire . . . . . . . . . . 1699

CHAPTER XV.

A History of Decoys, Past and Present (continued):-Yorkshire . . . . . I 76

CHAPTER XVI.

A History of Decoys, Past and Present (continued) :-Scotland . . . . . IS8

CHAPTER XVII.

A History of Decoys, Past and Present (concluded) :-Ireland . . . . . ISo

CHAPTER XVIII.

Decoys and Decoying in Holland . . . . . . . . . $\quad$. 197 


\section{LIST OF ILLUSTRATIONS.}

I. Old George Skelton

Frontispicie

2. Driving Wildfowl.

4. The Man who kills the Ducks outside the Decoys . . . . . . I6

5. View of a Decoy Pipe as seen from the Head Show Place . . . facing I 7

6. Decoyman taking Birds out of Tunnel-net . . . . . . . . 22

7. Decoyman enticing Wildfowl up the Decoy Pipe by the use of a Dog . facing 26

S. Entrance to a Decoy Pipe, with Dog at Work, and Vildfowl following him up the Pipe.

facing $\quad$;o

9. Decoyman driving Wildfowl up the Pipe

facing $\quad 3 \cdot 7$

ro. How to Cut the Ditch of a Decoy Pipe

facing $3^{6}$

I 1. Entrance to a Decoy Pipe

12. 'Tunnel-net .

13. Construction of Screens

I 4. Plan of a Three-pipe Decoy

fixims 55

I5. Plan of a Decoy Pipe.

facing $5 i$

r6. Plan of a Five-pipe Decoy .

fucing $5^{\text {s }}$

I7. Plan of a Cage Decoy

facing $\rightarrow$

IS. Plan of a Cage Decoy

. $\quad 72$

I 9. Morden Decoy, Dorsetshire.

. 73

20. Berkeley Decoys, Gloucestershire

facing 93

21. Ashby Decoy, Lincolnshire.

22. Friskney Decoy, Lincolnshire

facing

122

23. Didlington Decoy, Norfolk .

2.4. Sharpham and Sedgemoor 1)ecoys, Somerset

25. Lakenheath Decoy, Suffolk .

facing 93

facing 167

26. Combe Abbey Decoy, Warwickshire

facing 174

27. Hornby Decoy, Yorkshire

facing 9j

28. Escrick Decoy, Yorkshire

29. Meaux Decoy, Yorkshire

182

30. Watton Decoy, Yorkshire

3. Trap at End of Dutch Decoy I'ipe 



\section{T H E}

\section{BOOK OF DUCK DECOYS; \\ пиеке}

CONSTRUCTION, MANAGEMENT, AND HISTORY.

\section{CHAPTER I.}

TuE History of Tuck Decoys is surrounded by difficulties of no ordinary kind, for the art of constructing and working them was carefully concealed in former times, so as to prevent as much as possible any addition to the number already existing, which otherwise would necessitate a division of the spoil, that spoil being the myrials of willfowl which formerly haunted the fenlands of England. The Decoymen kept their secrets well, and were indeed forced to do so in their own interests, for it stood to reason they knew that the greater the number of Decoys in use the less would be each owner's proportionate share of birds. A Decoy was private property, was well protected by a wide ditch or high fence, and was as a rule in a retired and even remote situation. It was usually worked by one man, or perhaps by a father and son, and the owner purposely shrouded its management with mystery, and spiead absurdly inaccurate reports as to his manner of Decoying and of the accessories of the Decoy. He was always on the watch for intrulers and would on no account give them the slightest reliable information. He kept his successes as secret as he could in a day when it was a matter of a livelihoud to him to conceal them; for was he not fearful of an increased rent, or of some coretous neighbour setting up a I lecoy for himsclf harel ly, and so robbing him perchance of half his profits?

A Decoyman lived a lonely, quiet life, seldom attending fairs or markets; he conversed in a low tone, and his appeance and manncr was inoffensive and reserved; always as though groing stealthily for fear of 
alarming the ducks. He rented a considerable extent of land, mostly marsh and low wet meadow, in the vicinity of his Decoy, so as to keep off curious trespassers and to assist the natural solitude of its surroundings. He helped to support his home by grazing a few sheep or cattle on the dryer portions of the small oasis of fenland he occupied.

In the summer he cleaned out his Decoy, mended the banks and screens, and put his nets and pipes in order. His harvest of birds began in October and ended in March. During this period he was ever on the watch both outside and inside his Desoy; he lived, as it were, in a glass house, so that he could see on all sides and at all times what was going on. He matched his brains and experience against the cunning and wildness of the fowl he sought, and he usually won the contest.

When he dicd all he knew was handed down to his assistant in the Decoy, most likely a near relative.

All his successor learnt was izini inoce, or by watching his manouvres as he attended him in the Decoy from year to year.

So from father to son were the Decoymen of past generations. Is it, then, to be wondered that, under these circumstances, so little is now generally known of ancient Decoys and Decoying?

We do not expect a conjurer to divulge his tricks, yet as loth would an old Decoyman be to disclose his artifices of Decoying.

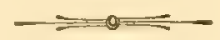

\section{The Derivation of the Word Decoy.}

Sir Henry Spelman, who died in 164I, says, "Sir W. Wodehouse (who lived in the reign of James I., $1603^{-25}$ ) made among us the first device for catching Ducks, known by the foreign name of a koye."

Though the statement that Sir W. Wodehouse made the first Decoy in England is without other authorization, it is a very probable one as regards its truth, and it is one that has been frequently copied from that day to this.

Although the name Decoy had been previously long in use in England, it was applied only to the tunnels of net resembling cares or pipes used for driving fowl into as afterwards clescribed, 
All writers agree - and there is no question - that the word Decoy came from Holland, where Decoys originated. It is an abbreviation of "endekooy," i.e., in Dutch, "the Duck Cage," and not merely of the word "Kooy," as stated by our lexicographers.

Some old writers speak of the Duck-Coy, a word which would also soon be shortened into Decoy; others allucle to the I )uck traps, i.c., Duck cages, the latter being a truthful rendering of the Dutch word.

There is no doubt that at first the word "kooy," otherwise "coy" (the cage), was used to represent the cage of net into which the fowl were driven in the early years of fowling, and in the later enticed.

I have no hesitation in saying that the first Decoys made, at all resembling in principle those at present in use, were ponds or lakes furnished with tunnels or cages of network into which latter the fowl were enticed by food and, when in, secured by a dropping framework of netting that was lowered by a cord, and closed the entrance.

One of our most ancient Decoys is precisely on this principle-that at Haughton, Notts. It is essentially a kooy or cage for catching ducks. Though doubtless such a cage was highly successful with hordes of wildfowl on all siles as in clay's of yore, still the more perfected pipe Decoy as at present in use is an immense improvement on it, though maybe suygrested by its forerumner the cage Decoy: The cage I Decoy' was, I consider, a simple device (driving the Ducks having gone out of fashion or being prohibited) in use by the Fenmen before they tock leseons from the Dutch in the formation of a better contrivance. ( $S c c$ plans of a Cage Decoy, pages 71, 72.)

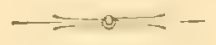

\section{The Origin and Age of Decoys.}

The first and most reliable description of a I ecoy in England for catching ducks by enticing them, is, in my opinion, that referred to by Evelyn which Charles II. made in St. James's Park. Evelyn writes in his Memoirs, March 29th, 1665, "His Majesty is now finishing the Decoy in the Park." It is highly probable that this was one of the first real Decoys made in England, and that "Sydrach Iilcus," who constructed it, was a Dutchman imperted from Holland for the pumpose. 
Full particulars of this Decoy will be found under its name, including the cost of the nets, reeds, poles, etc. used in its construction, and which, by the way, closely resemble the requirements of a Decoy of the present day.

I consider this the most valuable historical allusion to a Decoy extant. It is spoken of as a small Decoy in an island, and it is evident that it was a Decoy for catching ducks by alluring them into pipes or cages, and that reed screens were used as now. All published descriptions of Decoys previous to this date, except the somewhat vague allusions by Spelman, speak of Decoys into which ducks were driven and not enticed.

In former times vast hosts of wildfowl bred in England, especially in the fens that covered so much of our eastern counties, and which, though flooded in winter, partially dried during the summer. The guns of those days were powerless to thin their numbers, or to supply the markets. It is only natural that the peasantry should have set to work as best they could to obtain the birds for food and sale. We have, however, no reliable evidence that Decoys, as now known, were, even in a primitive form, in use before the micldle of the seventeenth century. Doubtless Decoys were generally established in the East of England soon after the first drainage of the Fens by the Bedford Level scheme in I653. Before that date the annual winter floods would by necessity have destroyed any chance of constructing Decoys in the Fen lands, though the said floods would favour the driving of Ducks as after described. This is quite borne out by Ray, who, writing in 1678 , speaks of a Decoy at that date as a "ncw artifice" latcly introduced by the Dutch, and he then proceeds to describe a Decoy for enticing wildfowl (much the same as now used). He also alludes to the great number of fowl caught in a Decoy in the winter.

It is true Decoys (so named) were said to have existed in the time of King John; mention is also made of them as having given rise to litigation as carly as 1280 , and again in 1415 and 1432 . At the last-named date a mob armed with swords and sticks took 600 wildfowl out of the Abbot's Decoy at Crowland monastery, infringing the rights of private property. Daniel, in his "Rural Sports," speaks of near 3,000 mallards being taken at one drive at Spalding. Willughby writes that sometimes as many as 400 boats were used in this driving of the ducks, and that he 
knew of as many as 4,000 birds being taken at one drive at Deeping Fien. Gough, in his edition of Camden, mentions that about 17203,000 ducks were to his knowledge driven into a single net at one time.

There are many accounts extant of this drieing of the ducks into nets in summer, and the birds are distinctly described as young or moulting at the time they were taken, and so were driven and hustled into nets by an advancing line of men and boats behind them. We also have a descrip-

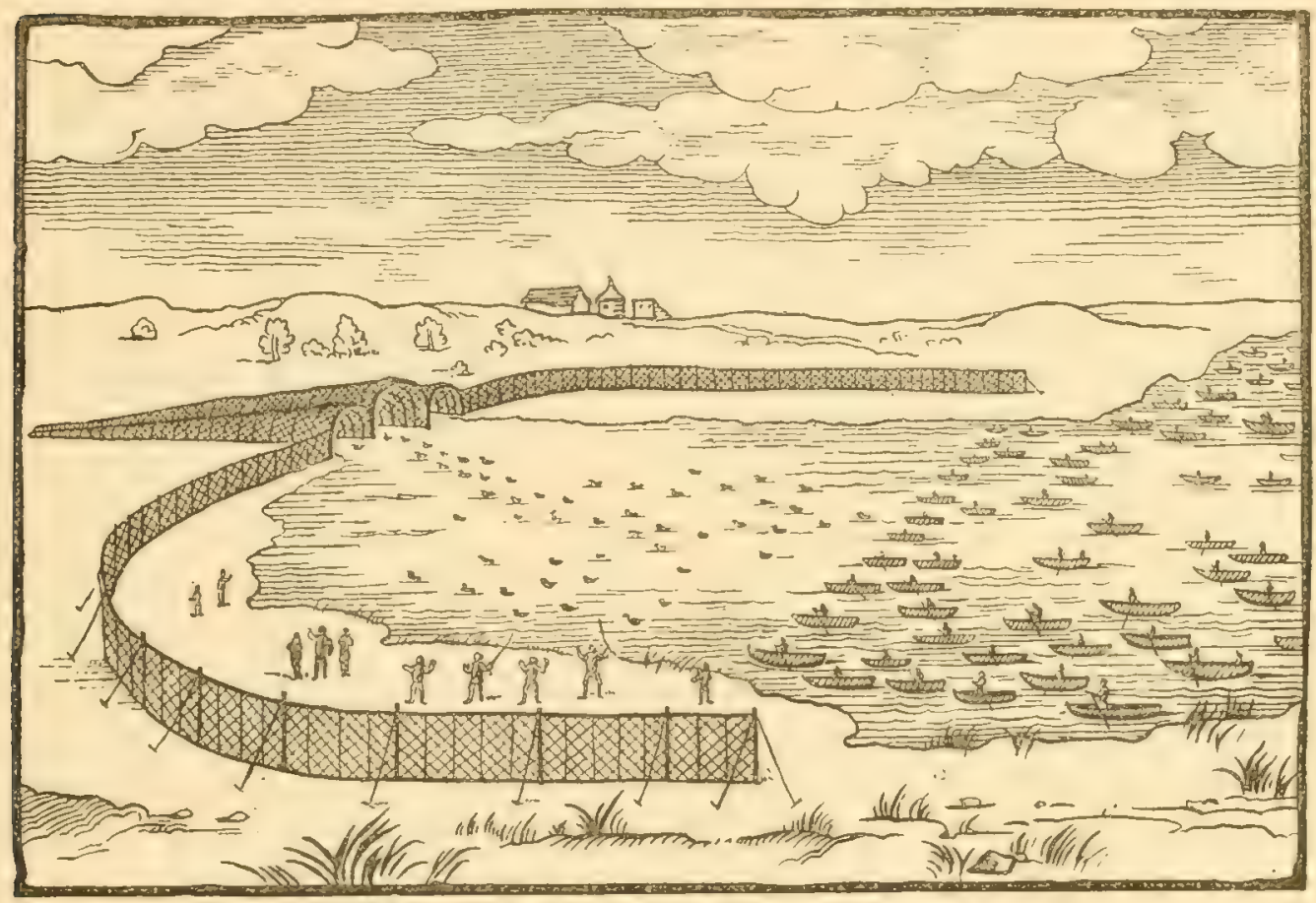

DRIVING WILPFOWL IN THE SIXTEENTH CENTURY.

(From an Old Print in the Author's possession.)

tion of the nets used. These were $V^{\text {- }}$-shaped and placed at a narrow end or point of a mere. They were long and strong, and similar in shape to our modern Decoy pipes, though necessarily much larger. 'The ducks were beaten out of the reeds and marsh into the water, and then the young birds, being unable to fly at all, and the old ones but little, owing to their "moultines" condition, all were easily edged on to their capture by a compact line of men and boats, just as a nct surrouncls a shoal of fish.

The actual nets the birds were taken in were llanked by other nets 
on either side of them, all of course tending to guide the fowl toward the net they were subsequently driven into as a huddled crowd. Sec illustration, page 5 .

As, however, this method of taking fowl swept them off wholesale, they naturally decreased in certain localities. As years went on the habit became generally common, till at last an Act was passed prohibiting it. This Act came in force in 1534 , and debarred fow being taken between the 3 rst of May and the 3 ist of August in every year.

Still willfowl protection" was not strictly enforced in those days, we may be sure, for the fen country, where this driving used principally to take place was well-nigh a toma incognitr. Driving ducks, however, was continued down to 1676 , as at that date Willughby alludes to it, as also does Gough still later, in 1720, when he speaks of the 3,000 ducks being taken at Croyland at one time in a single net. This might not be an infringement of the law, as the latter writer speaks of the ouncrs of the Decoy having had this large take of fowl. By owners, I consider were meant the people who were proprictors of, or paid taxes on, some particular piece of water which they reserved for wildfowl, as a Decoy is now.

There can be no doubt that driving ducks into a tunnel of net closed at one end was the original method by which they were caught, and that it suggested the formation in the first instance of the "cage," and later of the modern Decoy as now worked and constructed. For as the fens were drained, land apportioned, and the fowl became less abundant and tame, and firearms were improved and more used, people found they could not succeed in taking the birds as in days past.

If the ducks were not in sufficient numbers or had learnt to avoid the

* I find this protection was afterwards withdrawn, which no doubt accounts for the practice of driving ducks being alluded to in more recent times. For it appears that in the fourth year of the reign of Edward VI. (155I) the Act was repealed, but it was at the same time provided that no person should destroy or take away the eggs of any wildfowl. The recital of this latter Act is as follows, and for its quaint wording and allusions is worthy of insertion:- "Whereas in the xxy year of the reign of your Majestie's father of most famous memory, King Henry the Eighth, an Act was made containing two branches, whereof the one was against the taking of wildfowl between May 3 I and August 3 I with any nets or engines upon a pain limited therefor as in the second statute more largely doth appear: and forasmuch as the occasion of the second branch appeareth sithen to have risen but on a private case, and that no manner of common commodity is sithen perceived to have grown of the same, being notably by daily experience, found and known, that there is at this present less plenty of fowl brought into the markets than there was before the making of the said Act, which is taken to come of the punishment of God, whose benefit was thereby taken away from the poor people that were wont to live by their skill in taking of the said fowl, wherebye they were wont at that time to sustain themselves with their poor houscholds, to the great saving of other kinds of victual, of which aid they are now destitute, to their great and extreme impoverishing." 
nets, or the mere on which the nets were placed was not at the disposal of the fenmen, or the law forbacle the catching of wildfow in summer when young or moulting, then they set to work to cutice what fowl they could into the nets during the ainter, and so substituted trickery for brute force:

How completely they succeeded is well known. Instead of driving the fowl with a moly of assistants into a net at the end of a larece lake, they now preserved the ducks on a small pool, from which one man could lure them into a pipe or pipes attached to it, and take all the profit to himself in a quiet and methodical manner.

\section{WORKS RELATING TO Decoys.}

I possess numberless quotations from early and later writers who, whilst professing to (lescribe a l)ecoy, knew nothing whaterer of the sul)ject. All they were aware of was, that the eluclis were in some way caurht in nets connected with a small piece of water.

The operation of catching, and the arrangement of the Decoy, they never saw. But as they could not ignore the subject in the sporting and topographical works of the day, they drew upon their imasinations, or eagerly copied one another's statements.

Some of their conjectures were ludicrous in the extreme. One writer affrmed that the whole 1 tecoy and its enclosure was surounded and corered in with a huge net. Another, that a dog was sent into the water at clusk to allure the ducks by swimming among them, and that the ducks swam at the dog to cat him, thinking he was a shoal of fish, and were so led into at net. A third contended that a dog was required to alarm the fow off the: water in the first instance, and afterwards to drive them into the net liks a flock of sheep.

The earliest attempt at a true description of a Decoy for enticing ducks occurs in the ('nie'rsal Mergaine of April, 1752. The writer really. narrates with tolerable accuracy the general outline of a Decoy and its manasement. He evidently on one occasion paid a visit to a l)ecoy, but doubtless was rather puzzled to remember arisht all he saw therein when he wrote up his notes at home. Still his account has a vein of truth throughout. Blome in I696, Bewick in ISo4, Pennant in IS I 2 , and Oliver Goldsmith in 1816, also each give some sort of an idea of a Decoy, as does Nicholson in "The British Encyclopedia" (I 809 ). 
Naxwell in 1830 is as good as any, and being an energetic sportsman and favoured writer, no doubt had means of personally inspecting a Decoy.

In the "London Encyclopredia," I 839 , is a short but accurate notice of a Decoy, and how it is worked.

Some other references to Decoys are as follows: "England Illustrated" (R. \& J. Dodsley, London, I 764). “Itinerarium Curiosum " (William Stukeley, M.D. Second edition, 1776). This author gives an excellent account of a Decoy, togrether with an accurate plan of a five-pipe Decoy' almost exactly similar to one given herein. "Bradley on Gardening" ( 1 ₹26). "A Natural History" (John Bigland, I 806).

In more modern times came Lubbock with his charming account of the "Fauna of Norfolk" $\left(1 s_{45}\right)$. He clescribed a Decoy as he knew it and saw it, the one that belonged to his friend Mr. Kerrison at Ranworth Broad. He simply gave the result of his own observations and borrowed from nobody. Next we have Folkard, who, devoting several pages to the subject in his "Wildfowler" (first edition, 1859), epitomized and criticized many previous writers about Decoys, collected information as to their history and construction, and faithfully described them in a general way from his personal acquaintance therewith.

Then we have Mr. Thomas Southwell of Norwich, who contributed to "The Transactions of the Norfolk and Norwich Naturalists' Society" in I $S S I$ an excellent paper on the Decoys of his own county. He took great pains to gain particulars of the Norfolk Decoys, and I am much indebted to him for the privilege of using the results of his researches in Norfolk, as well as for his interesting notes of the "Skelton Family."

Next, in I883, Mr. C. Davies published a work on the "Norfolk Rivers and Broads," with some excellent sketches of the Decoy pipes at Fritton Lake, reproduced in "Peter Penniless," by the same author (1884).

In "Yarrell's British Birds" (fourth edition, I 885) is a faithful though brief description of a Decoy, furnished by the Rev. Richard Lubbock, author of the "Fauna of Norfolk," for the first edition of the "History of British Birds."

As I have said, many other references to Decoys exist in various works which I have not quoted, but they are one and all either too absurd or too meagre to deserve mention.*

* A long and curiously ridiculous plan and description of a Decoy nzcurs in "Loudon's 
It is an interesting fact that the very curious engraving of a Decoy here given should coincide in date ( 1665 ) with the one alluded to by Evelyn (page 3). This is the carliest skcteh of a I ecoy and its pipes as now' used in existence. It is from "The Iables of . Isop", l'araphrased in Verse, adorned with Sculpture and illustrated with Annotations. By John

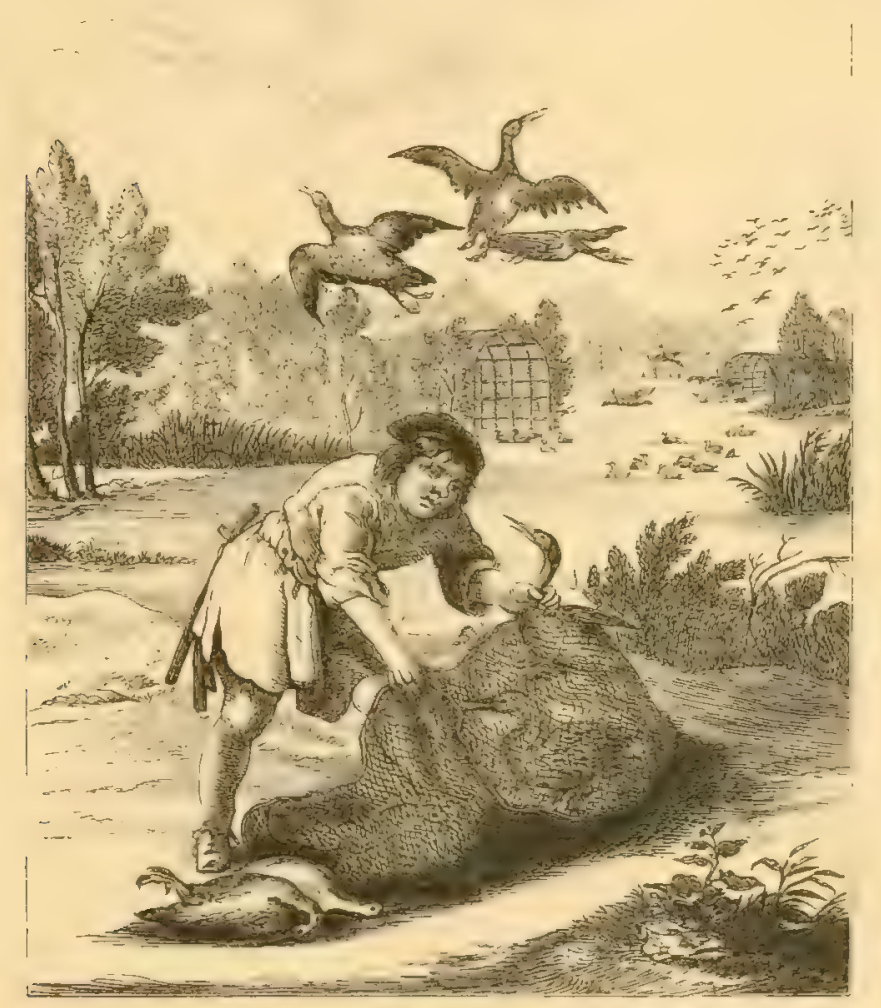

OLD ENGRATIAG OF A DECOY (1665).

Ogilby, Lsq., Master of His Majesty's Revells in the Kingdom of Ireland. London: Printed by T. Roycroft for the Author, anclxv." Fable Lxxix., "The Husbandman and the Stork," page 200.

Encyclopædia of Agriculture," 5th edition, I844, page 1,092 ; and one which is partially copied into "A Dictionary of Science and Art," by Brande and Cox (I865). 


\section{The Position of Decoys in the British Islands.}

It is pretty certain that Decors for catiking ducks were first used in Lincolnshire and Essex. and that the neighbouring counties of Northampton. Cambridge, Xorfolk. Suffulk, and Yorkshire followed suit.

The stronghold of Decoys was at and near Holland Fen. Spalding, Crowland. and Lincoln, and more than anywhere tlse between Wainfleet and Boston, some of the best being at Friskney.

This is not a matter of surprise when we consider the intercourse that formerly- existed between Holland and the harbours of the II'ash by means of small trading ressels, as related by local historians of the day.

So it was also with Eseer and Suffilk, for the I Dutch were continually. trading to the rivers and ports of thnse counties long ayn, both as smugglers, fishermen, and merchants.

On seeing the immense number of wildfowl that haunted the fens of Lincoln, both near the coast as well as inland, the Dutch naturally either suggested the making of Decoys in their own interests. or for the friends they risited. They doubtless saw that the wholesale method of driving the ducks was through various calsess such as drainage and protective laws soing out of use-a methol no doubt originally tuught by themsetres. as the name implied. But they had given up the system too. probably on account of its only bein feasible occasionally: it also required a host of men and bouts, the profits were hared by a mob: in addition to this, the fowl were taken when not full-grown or in groul cundition. They therefore twught, or at all events assisted, the fenmen to construct Decoys on a much improved principle, and a far more remunerative one to their individual owners.

But unlike the compact Lincolnshire Decors, the Decors of Norfolk till the end of the last century consisted of extensive lakes. To these were attached several pipres, according to the success expected. or afterwards encountered.

These large stragyling lakes were, however, ill adapted for Decoys. Very likely they had leen previously used for driving fowl, as was the case in Lincolnshire, and that the pipes, when the people took to enticing ducks up them in winter, instead of driving them into them in late summer. had by degrees been greatly reduced in size. 
But at last came a radical change. An old man named George Skelton emigrated from Friskney, the home of Decoys, to Norfolk. He at once condemned the large Norfolk lakes as Decoys; he plainly showed that on such extensive waters the fowl were out of reach of the Decoyman and his allurements, that the birds had not sufficient shelter thereon, and that from their size it was not possible to keep them clear of ice. He put his words to grood proof, for Lubbock tells us that "Mrr. Huntingrelon of Somerton being about to form a Decoy out of a low and overgrown part of his marshes at Winterton, engaged an elderly man named George Skelton from Friskney, in Lincolnshire, and desired him to state the size which he preferred for his Decoy. To every one's amazement, from two to two acres and a half was the space wished for: workmen were put on, and the Decoy in miniature, as compared to others in Norfolk, was soon completed. Other Decoymen laughed when told of the petty puddle in which Mr. Skelton chose to exercise his skill. But laughter ceased and amazement began, when, in the second year of his superintendence, Skelton took I, Ioo teal in seven consecutive day's."

Till the end of the last century, Lincolnshire was certainly the county most famous for Decoys, and in which a greater number existed than elsewhere. Pennant records that 31,000 ducks were callyht in one season in ten Decoys in the neighbourhood of W'ainfleet, Lincolnshire, and adds that the Decoymen "would be slad to contract for years to sell their ducks at 5 d. apiece."

At the Ashby Decoy, in Lincolnshire, even in comparatively recent times $(1834-1868)$, the Decoy Book accounts for just 100,000 duclis in thirty-four seasons of catching.

Now, though Lincolnshire had great returns, other countics did wonderfully well, particularly Essex, with its immense estuaries and their feeding grounds to attract the fowl.

The Essex Decoys were individually famous ones, and rivalled in number those of Lincolnshire and Norfolk. Suffolk contained a fair number, but Cambridgeshire and other adjoining counties only a few.

Yorkshire boasted several in its eastern division, about the great marshes of Holderness. Dorset and Hampshire had one or two each. Kent a couple. There were a scorc or so in Ireland, none in Scotland, and but few in Wales. In Somerset, especially about the vast morasses 
of Glastonbury, Decoys have long existed - a dozen or more. The wild moorlands and fluoded marshes formerly so numerous in that county were highly favourable for attracting wildfowl. But later on I shall treat of the Decoyss and their respective counties in alphabetical order, and shall give the history and position of each as distinctly as possible.

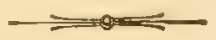

\section{The Skeltons.}

This was a famous family of Decoymen who came from Friskney, in Lincolnshire, at the beginning of the present century, the various members of which constructed or remodelled nearly all our best Decoys, past and present, and a few of their descendants are still in active work as Decoymen to this day.

The Skeltons were unrivalled in their knowledge of Decoying and skill in the construction of Decoys, and were, as I have said, the first to introduce into Norfolk the small pools of their native district in lieu of the large lakes previously used as Decoys in that county.

The first of the name to leave Lincolnshire was "Old George Skelton"; he was brought to Somerton in 1 So 7 by Mr. Huntington, to design a Decoy for him on his estate, an account of which transaction I have given.

Old George was accompanied or soon followed by his four sons, George, William, Richard, and Henry.

Old George, as stated, made, and till his death worked, the Winterton Decoy in Norfolk. He died in 1840 , aged eighty, and was buried in Winterton Churchyard.

His son William removed to Combe Abbey, Warwickshire, where he made a Decoy for Lord Craven, and worked it till his death in I867, at the age of seventy-eight: he also made several others, including Lord Caledon's in Ireland. William had two sons, of whom one, T. Gilbert Skelton, lately constructed ( 1885 ) Lord Lilford's Decoy' near Thrapstone, and the other holds a large farm under Lord Powerscourt in Ireland.

Richard Skelton was for many years Decoyman for the Gurney family at Hempstead. He left that place and took a Decoy at Methwold shortly before his death, which occurred in I $S_{4 y}$, at the agre of fifty-three years. 
He had five sons, three of whom died young. His son Richard, now in the service of Lord Lilford, was many years 1)ecoyman to Mr. R. Page at the Marsh House Decoy in Essex, and Henry is ganckeeper at Wooley Park, Nantage. There was also a daughter, who married a Mr. Kegister, and who is now living at Southery, near Downham Market, in Norfolk.

Henry Skelton, the fourth son of old George, succeeded his father at the Winterton I ecoy. He died in I\$61, aged fifty-two years, and was buried near his father at Winterton.

Old George, and equally so his four sons, were skilled in all connected with Decoys to a degree no one has since attained, or perhaps, for that matter, ever equalled in days previous.

I will now speak of the eldest son of "Old George," who, after his father's death, was always himself alluded to as "Old George Skelton."

In I 806 "Old George" the second, with his brothers William and Richard, erected the Methwold I)con, and worked it for fifteen years. He then removed to Dersingham, where, about $18 \mathrm{~s} s$, he set up a Decoy: This he worked till his death in 1857 . In the meantime, howerer, he had worked the Irormegry Decoy for a short time, and constructed one at Narford Lake and another at South Acre, both for the Rer. Mr. Fountaine. He also made one for Lord Bateman at Shoblen, in Herefordshire, besides assisting in constructing one at I Lornby Castle, for the seventh Duke of Leeds. In remodelling the Wretham I)ecoy in Norfolk for Mr. Birch he caught a severe cold, from which he never recorered, and died at Dersingham on February 14th, I 857 , at the age of sixty-seven years.

This George Skelton is described as a "very peculiar man," short of stature, web-footed like a duck (see Frontispiect), very strongly built, particularly kind in disposition, perfectly indifferent to cold and hardship, well-informed, and unequalled in skill in the construction and management of Decoys.

With all these adrantagres he might have died in comfort and even affluence, but unhappily late in life he gave way to a passion for drink, probably engendered by the cold and hardships he underwent in his profession. This greatly impoverished him. A gentleman who visited him on his deathbed thus described his visit to Mr. Southwell :- "The house Skelton lived in stood quite alone in the marshes, no great distance from the seashore, and was at that time at ieast two miles from any other dwell- 
ing. It consisted of a long, low, and gloomy room. On asking for him, his wife pointed to a corner of the room. On looking there I could see nothing but ducks and wildfowl hanging on strings. On repeating the question where Skelton was, some of these strings of wildfowl were taken down, and I found him lying on a four-post bed. These strings of wildfowl were stretched from one post to another all round the bed, so as to form regular curtains, that shut him in completely from view." He died from a thickening of the membrane of the throat, brought on by exposure to damp and cold, and greatly aggravated by his habits of intemperance. George Skelton was twice married, and left one child by his first wife, and five by his second. He had more experience of Decoys and Decoying than any other member of his family, not even excepting his father.

The likeness of him in the frontispiece I am able to give through the kindness of the Duke of Leeds, who possesses the original picture. On it is written, "Old George Skelton appearing with the first fruits of the South Acre Decoy, Nov., I854."

\section{The Law of Decoys.}

This need only occupy a page or two.

A Decoy is considered to be a private preserve containing wildfowl valuable to its owner for food or sale.

The Decoy owner expends money and employs skill in taking that which is of use to the public. It is a profitable mode of employing his land, and was considered by Lord Holt as a description of trade. He depends upon his Decoy as a source of profit; if a poor man, for his livelihood. Though he can lay no claim to the ducks, when flying outside his Decoy, he is protected by the law from injury to them when within the precincts of the Decoy. Though Decoys have no special Act for their safety, yet they are protected by Common Law from wilful damage, whether it be to the Decoy, its nets and fences and other accessories, or to the ducks in it.

Any wilful act intended to deteriorate the value of the Decoy, can be prevented, or the owner recover damages for, just as he would in any ordinary system of trade, if he were annoyed and suffered loss thereby. 
A neighbour may on his own land, however near it, fire a gun at wildfowl passing over him, whether they be going toward the Decoy or otherwise, but he cannot fire a bullet or shot actually into or over the Decoy to wilfully disturb it, whether his object be to raise the ducks so that he may get shots at them as they pass near him, or merely to satisfy a grudge against the Decoyman by hindering his successes.

Such conduct is actionable, because it is malicious injury to valuable property, as it would be did he light a fire to stink the ducks out of the Decoy, as has been sometimes done.

If a man invade the Decoy he can, of course, be sued for a trespass by its owner in the ordinary way.

If he, from outside the Decoy, though he be on his ow' land, wilfully cause damage to the Inecoy by alaming the ducks in it with an eirdent malicious intent, he can be prevented by law, and the Decoy owner can recover compensation. For though the owner of a Decoy has no property in the wildfowl that frequent it, yet an action is maintainable at the suit of the Decoy owner if a person, in order to scare away the fowl and in the exercise of no reasonable right of his own, wilfully shoot even on his own land, because such an act is within the rule laid down that no man is to be injured in his trade.

There are several well-known cases affecting the rights of Decoys, two of which I will briefly refer to.

In 1706 an important test action was tried concerning the rights of a Decoy. Two Decoys were situated close to one another. One owner was jealous of the other's successes.

He therefore went to the immediate vicinity of his rival's Decoy, and on two occasions fired off a gun repeatedly to damage it, and to frighten away the ducks in his neighbour's Decoy. This case was twice argued before the Court of King's liench, and the arguments are fully given in "A Report of all the Cases determined by L. C. J. Holt," p. I4.

The judgment of the Court was griven in favour of the plaintiff, and was to this effect :-

"That the plaintiff had learned the art of alluring wild ducks to a pond on his private property, and that he did so for his own pleasure and profit, as he had every right to do.

"That in doing so he was put to considerable expense and trouble, in 
order that he might supply the markets with valuable produce, and so be recompensed by the sale thereof.

"That the person who made the Decoy should benefit by the skill, outlay, and care requisite to construct and manage it.

"Thus the owner of a Decoy had every reason to expect the law to protect him from wilful injury to it."

The compensation allowed was $£ 20$, not for the actual loss of the fowl, as such could not well be calculated, but for the disturbance of the Decoy, which really means the same thing.

This case was known as Keeble $v$. Hickeringall.

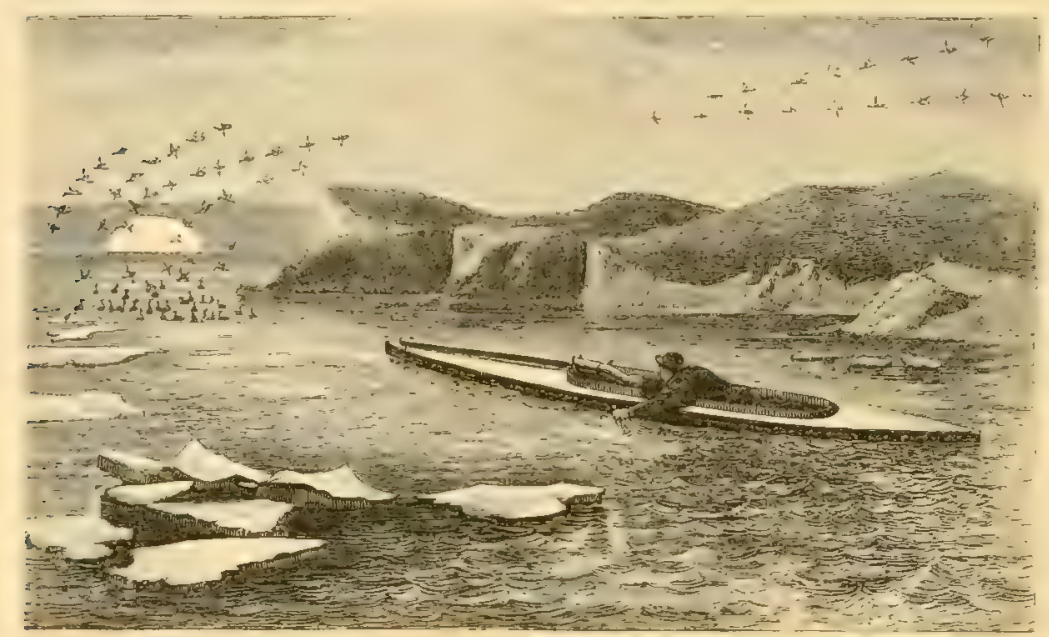

THE MAN WHO KILLS THE DUCKS OUTSIDE THE DECOY.

Another case of the kind occurred afterwards - an interesting one, as it was shown that no one had a right to wilfully disturb a Decoy even from the distance of several hundred yards, or when in a boat on tidal water.

The action arose from a wildfowl shooter on a tidal creek near the Decoy, firing a gun from his boat on purpose to disturb the ducks. After alarming, and so driving the fowl from the shelter of the Decoy, the shooter shot several as they passed near him. He did not approach the Decoy nearer than 200 yards.

The defendant reasoned that he had every right to fire at wildfowl 



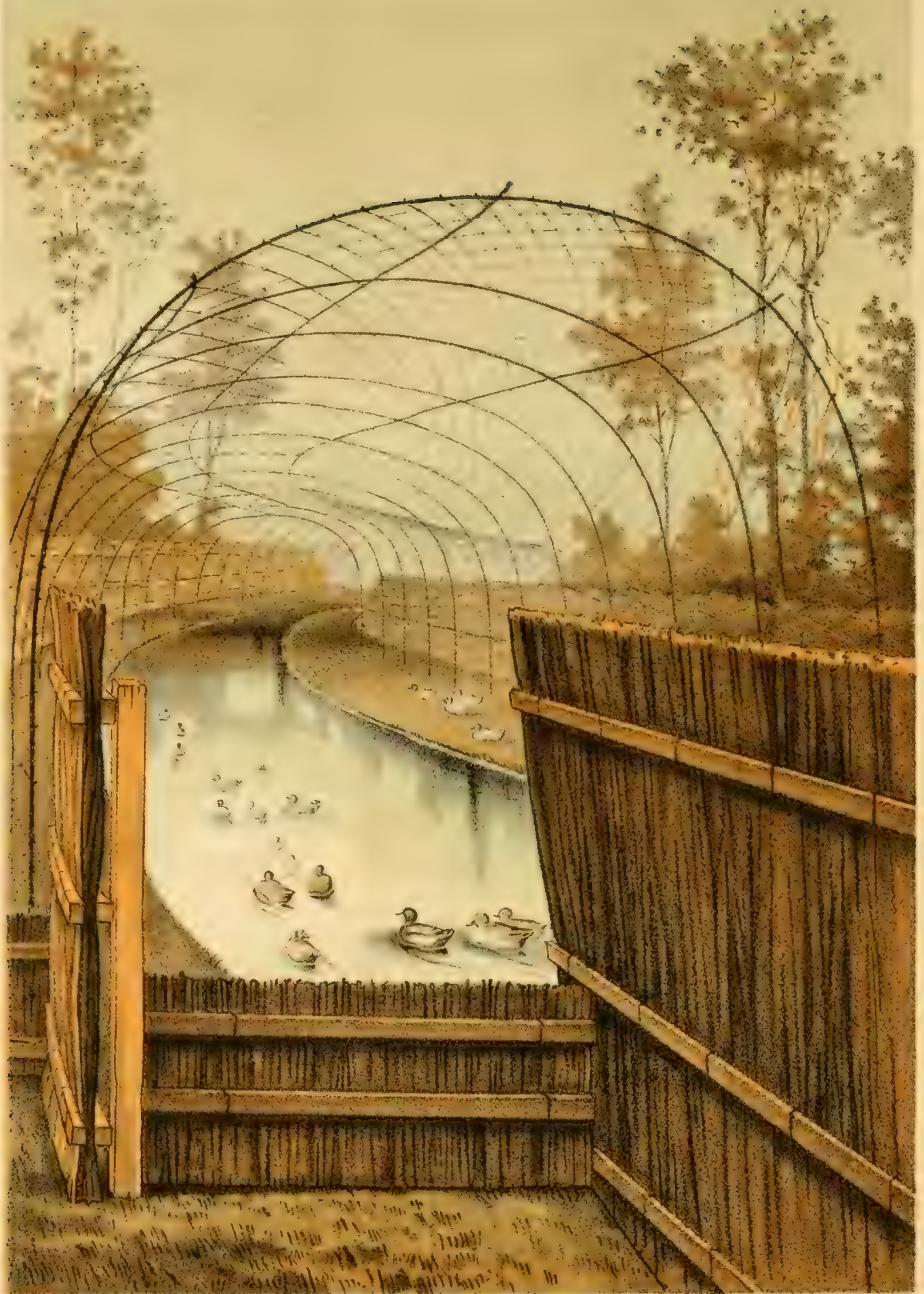


in an arm or creek of the sea wherein the tide ebbed and flowed, and that was free to every one; and, further, that he had not ventured upon the land near the Decoy.

But the Court held that a Decoy was protected by law, as were various other properties that required guarding against wilful damage. This case was also quoted in favour of the plaintiff.

It is known as Carrington $\%$ Taylor, is reported in II East, 571; 2 Camp. $25^{8}$; and the Decoy it occurred at was the one at Beaumont cum Mose in Essex in 1810.

\section{The Phraseology of a Decoy.}

A Decoy is a cunning and clever combination of water, nets, and screens, by means of which wildfowl, such as IVigeon, MIallard, and Teal, are caught alive.

A Decoyman is the man who works and manages the Decoy, and who by his art, as well as by his knowledgre of the birds and their surroundings when in the waters of the Decoy, entraps them.

The Piper is the dog used in Decoying.

The Pipes are the long, curving, net-covered ditches in which the actual capture of the ducks takes place.

The Screcus are the reed shelters from behind which the Decoyman, unseen by the birds, practises his allurements on them.

The Hoops are the curved rods of wood or iron, half circular in shape, that span the ditches like arches, and support the netting.

The Head Shew is the spot at which the Decoyman first appears, when he gets behind the ducks to frighten them up the pipe they have been lured into. (See opposite page.)

The Breast-wall is formed by the one or usually two screens that flank the right-hand entrance to a pipe on looking down it, and which shelter the Breast-wall Landing.

The Draught of a Pipe is the part of the pond that, getting narrower as it leaves the main water of the Decoy, leads to the pipe's entrance.

Recd Edges are the small beds of reed usually placed about halfway between the mouth of each pipe for the fowl to hide in, as is their custom at times. 
Dow Fumps The low short screens, that connect the ends of the high screens, placed for the dog to jump over when decoying.

The Yackoop (from Wake up) is the dog-jump between the breast-wall screens.

Tunnel Net. The extreme end of the pipe, and which is detachable when it contains birds.

Landing-places are the smooth banks that flank the mouth of each pipe, to tempt the fowl to rest thereon, and which are called the Breastwall and the Back-wing Landings. When so resting the fowl are said to be "banked," and are then at a negotiable distance for decoying up the pipe near which they happen to sit.

Decoy Ducks are the tame birds always kept in a Decoy to assist in luring the wild ones up the pipes, as well as to attract them to, and by their fellowship keep them in, the Decoy.

Food. The grain used for feeding the fowl up the pipes.

Turf consists of a piece of burning turf or peat, which, with a piece of sharp stick stuck into it as a handle, is kept near the mouth, and breathed on to destroy any smell of the breath or clothes of the operator, when the Decoy is visited or worked.

I will next describe the aspect of a Decoy, then the construction and working of it.

I will be as concise as the subject allows, and in order to make my description as useful and comprehensive as possible; will print the instructions and remarks as distinct as I can.

For a plan of a pipe illustrating its phraseology see illustration facing page 57 .

\section{What a Decoy CONSISTS OF.}

A piece of open water of from one to three acres, of a uniform depth of two to three feet, though shelving shallower to the sides, and surrounded by trees and shrubs.

Attached to this open water are from one to eight curving ditches; the usual number being three to six, seldom less or more.

Each ditch has a width at its mouth, under the first hoop, of from 
18 to 2 I feet; rarely more than 2 I feet, though in some cases a foot or two less than 18 feet.

These ditches are 60 to 70 yards long on the outside of their curves, and by degrees they taper away from their wide or pond ends to a width of only 2 feet at their extremities or tail ends.

The depth of the ditches is I foot to Is inches at their entrances, and shallowing to a few inches only at their narrow ends. They twist away from the pond into the brushwood and trees out of sight, so that any one looking in at the mouth of a pipe could only see up about half way, owing to the way the ditch curves.

Over each ditch, and fixed on its banks, are placed arched iron hoops, in former times wooden, 5 feet apart, the first one of which, near the mouth of the ditch, is from 12 to 15 feet high from the top of the arch to the water beneath.

These hoops get lower and lower, and also of course narrower and narrower, as they follow at short intervals the course of the ditch they span, till at the end of the latter they are only 2 feet high.

Over the hoops is stretched netting, making all appear like a huge serpent-shaped cage. The ditch and net-covered hoops form a Decoy Pipe.

Along each pipe, for two-thirds of its length on the outside of its curve, and 2 to 3 feet distant from its bank, are placed ten to twelve overlapping reed screens, each 12 feet long and 6 feet high, hesides a much longer one outside the mouth of the net-covered pipe, known as the head end screen, and two others beyond this, called the breast-wall screens.

These screens are so arranged in echelon that the Decoyman can pass along them out of sight of the pipe. Nor can any fowl on the pond, or any birds he is decoying up the pipe, see him or his actions.

The posts of the 12 -feet screens are 3 feet apart where they overlap at their ends, and the spaces between them are joined by lower screens, 2 feet 6 inches high, called dog-jumps.

At various parts of the pond edge are the smooth banks called "Landings."

The pond itself, as well as the mouths of the pipes, are also more or less surrounded by screens or "banking;" judiciously placed, so that the Decoyman can, through small peep-holes, observe the birds from behind 
shelter, or move from one part of the Decoy to another unobserved by them.

With a quiet neighbourhood of meadow, wood and water, and sometimes marsh, for a quarter of a mile or more on all sides, to add to the sceming security of the ducks, we have in this description the general outline of a Decoy.

For a sketch of a Decoy illustrating its formation see plan facing page 55 ; and for an enlarged plan of a Decoy Pipe refer to cut opposite page 57 . 


\title{
CHA PTER I I.
}

\author{
DECOYING.
}

The System of Catching the Birds when in the Decoy Piles.

In all Decoys, the sole object of the Decoyman is to induce the wild ducks to enter under the netting of a pipe, and then to swim up its ditch to such a distance that he can cut off their retreat back to the pond.

This latter maneure the Decoyman achieves by getting behind the birds when he has enticed them far enough up the pipe, and then, by suddenly showing himself, first at the entrance of the pipes, and afterwards over the dog-jumps between the screens as he quiclily passes along their rear, he frightens them up it.

This feat is the backbone of I lecoying. The surprised fowl having no time to consider, and sooner than pass by the Decoyman, who, so to speak, bars their way back to the pond argain, they dash away from him up the pipe.

Such a course they would never take but that the bend or twist of the pipe, which hides its fatal closed end, deludes them into thinking, in their hurry and confusion, that it leads round its curve to open space and so to freedom.

It is an act that when suddenly alarmed they cannot weigh the wisdom of, though in their cooler moments they are with difficulty induced to swim even a few yards up a pipe for fear of a snare.

As they follow one another pell-mell and wild with fright, rebounding against the net of the pipe as they drive along, they become more and more confused and crowded, and still less able to judge whither they are speeding.

Yet on they so, for are they not conscious of the dreadful form of the 
Decoyman ever bchind and even approaching them?* (Sce illustration facing page 34.)

Finally, instead of escaping, poor deluded bircls! they are taken in the tunnel net that forms the tail of the pipe, panting and exhausted.

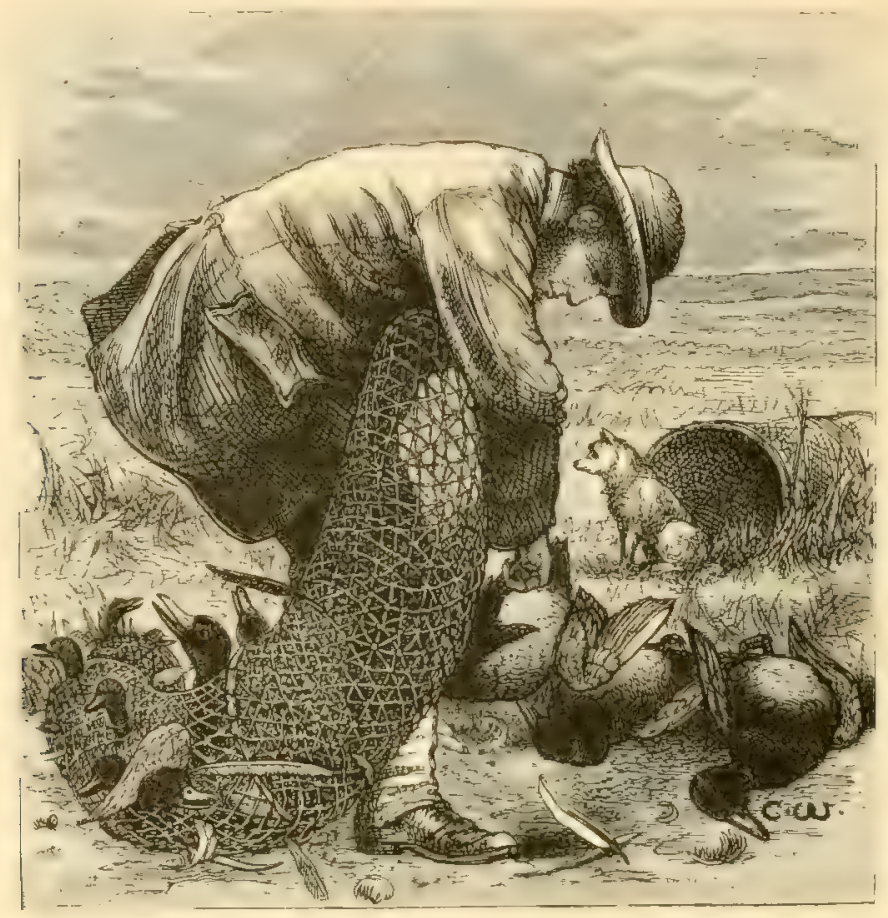

I) HCOYMAN TAKING BIRDS OUT OF TUNNEL NHT.

How all this is achieved without another bird in the Decoy being alarmed will presently be seen.

Thie Methods used by the Decoyman to Decoy the Ducks out of the Decoy Pond into the Pipes, and the Reasons why he is ABLE TO BRING ABOUT THIS RESUI,T.

We have just seen what occurs when the ducks are enticed far enough up the pipe for the Dicoyman to drive them into the tunnel net

* It was the custom long ago for a Decoyman to sport a scarlet coat, believing that therein he was an object of greater terror to the fowl when driving them. 
successfully. I have yet to explain why and hoze the birds are induced to go the necessary distance under the net to find themselves in such an unpleasant dilemma.

The actual decoying or luring of the fowl up a pipe, and well under its net, is achieved by two methods only: Though the means used are quite distinct, they both tend to the same end, and that end, by the way, is the tail end of a pipe.

The wished-for result is brought about by either dogging or feeding. as Decoymen call it, or both systems combined; that is by using a dog, or else by the use of food, such as wheat, oats, or barley.

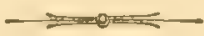

\section{DOGGING.}

A dog is brought into play to attract the fowl far enough up the pipe to enable the Decoyman to cut off their retreat back again to the pond.

Here I will digress a little, and say it is pretty well known how curious birds, and especially wildfowl, are.

They are likewise great braggarts.

So are sheep and other animals.

So are cattle and geese.

If a dog chases sheep, cattle, or geese, they run from him in alarm; should he hesitate or turn tail, they in their turn go after lim. This they will do, with every expression of courage, as well as of defiance.

Anything that appears strange or unusual in their eyes is a great attraction to a bird or animal, and in this consists their curiosity. I have seen tame Decoy ducks almost peck a fox curled up asleep, or seemingly so, on the bank of a Decoy.

So with the wild ducks, if they see a dog hopping about near them, now close by, now lost to view, their curiosity and excitement cannot hold them. They must follow to know more about it, and so they do too, necks craned and eyes brightly inquisitive.

Their courage and curiosity last just as long as the dog retreats before them, as they think he does.

They know nothing. of course, about the Decoyman hidden from 
their view behind the screens, who is really beckoning the dog up the side of the pipe and from the ducks.

Should the dog turn about and face them with a whine, or even look over his shoulder, off they all splash in a flutter, till he once more retires before them, when they follow him as before, and are thus gradually enticed on to their fate.

The natural instinct against a fox is very strong in all birds, but especially so in regard to ducks; for is he not always ready to pounce upon them unawares when enjoying a siesta, or even when sitting on their eggs?

Should a fox sneak along the banks of a Decoy, every duck is on the alert at once. They rush after him. I have seen them.

They take good care, however, to keep at a safe distance; and as with a dog, should he turn towards them, they tumble over one another in anxious flight.

I consider the ducks believe a dog to be in some sort a fox, or nearly related.

A fox-coloured dog, with a good brush, is always a successful Decoy dog, if he otherwise does his work well.

Ducks therefore follow dogs and foxes from curiosity, from hatred, as well as from braggadocio, and also because when he retires from them they imagine that for once in a way they are driving off a cruel oppressor-a natural enemy. They flatter themselves that their bold looks and assembled numbers bring about this satisfactory result.

I know a curious instance of this ; it is as follows :-

A friend of mine who owns a Decoy observed one day a fine tox sitting upon the ice, during a hard frost, in the centre of his Decoy Pond. The wild ducks literally crowded round him in a ring, just as if he were haranguing them, or were a politician at an electoral meeting.

When the inquisitive ducks edged up, as Reynard judged, within his reach, he would slowly gather his hind quarters together and then suddenly spring at them.

But owing to the slippery ice his foothold failed, and a ludicrous somersault was the result of his efforts.

The ducks rushed off in dire alarm, half scrambling, half flying, only to face about and gradually draw with inquiring looks and low interrogative 
"quacks" towards the fox agrain, as he once more recorered his composure and sat up on his haunches as before.

The fox made sereral futile attempts at a capture, only to get an absurel sprawling fall every time he tried to spring.

Finally, he left the ice looking sulky and supperless, the ducks following him to the bank as he retired. This very fox my friend once caught in the tunnel net of a pipe, whither he unadvisably let himself be driven. He had just previously been seen sneaking about the inside of the pipe after the Decoy ducks. He was caught and well whipped with a light twigr, as a warning to him to leave the Decoy and its ducks alone. This was at a time when the pond was covercel with ice. By the next morning the fox had well avenged the insult to his person, for at daylight not one out of seventeen Decoy ducks was left alive. Heads in one direction, bodies in another, and blood and feathers all over the ice of the I)ecoy. I need scarcely add that the fox-hunting folk, when they heard of the affair, were greatly amused, and hinted at a " just retribution."

I have said a good deal about ahy the ducks follow the dog, I will now explain how' they are induced to do so, and describe the part the dog takes in the pantomime of decoying the ducks.

His master, the Decoyman, whom he knows well and obey's implicitly; whether the order be griven by a whisper or by a move of the hand, signals him to the mouth of the pipe and bids him by a sign lie down behind a screen.

The Decoyman next cautiously reconnoitres, throughl the peepholes in the screens, the ducks swimming about the pond; and near the mouth of the pipe he las decided, owing to favourable circumstances, to work. He has, of course, selected a pipe that suits the wind, and about the mouth of which, and on the banks near, the birds are gathered.

After noting the position of the fowl, he, by a sign, directs his dog to bound over one of the doy-jumps near the month of the pipe. He takes care that the dog has no birds above him up the pipe, but that they are always on the pond side of him, so as to follow, not to meet him. In the latter case they would not Decoy.

The dog having jumped into view from the corner of the screen, runs 
round its front between it and the ditch of the pipe, and pops back over the next dog-jump behind the same screen.

He repeats the mancuvre, springing into view of the ducks again from the jump he just disappeared over, and so encompassing screen number two.

This alternate jumping into sight, followed by a short, frisking run, and then the vanishing again on the part of the dog, is continued from screen to screen till the ducks have followed the enticer well under the net and too far for their safety.

The Decoyman, hidden himself, also moves from screen to screen towards the tail of the pipe, keeping pace with his dog, and taking a quick look now and then through the peep-hole in each screen in order to see how the ducks are progressing up the pipe after the dog. (See opposite page.)

The latter he encourages by gestures to be smart and cheerful in his movements, rewarding him from time to time with titbits of cheese, meat, or cake.

If he sees the ducks hang at one spot and hesitate to proceed, he puts his dog quickly round the scree.s just above them, two or three times in succession. This will usually bring them on. It sometimes happens that the landing under the Breast-wall screens has fowl on it that cannot see or will not follow the doy as the latter appears from behind the screens near the pipe.

In this case the Decoyman puts his dog over the "Yackoop" between these two screens and right among the birds, when, though apparently very alarmed at first, they usually, some of them, end by following their disturber up the pipe.

The sprightlier the don works, the better, so long as he is absolutely mute and obedient.

I need scarce note that the dog, starting at or near the mouth of the pipe, continues his erratic course invariably towards its tail end, taking each screen and its jump in succession. 
To face page 26

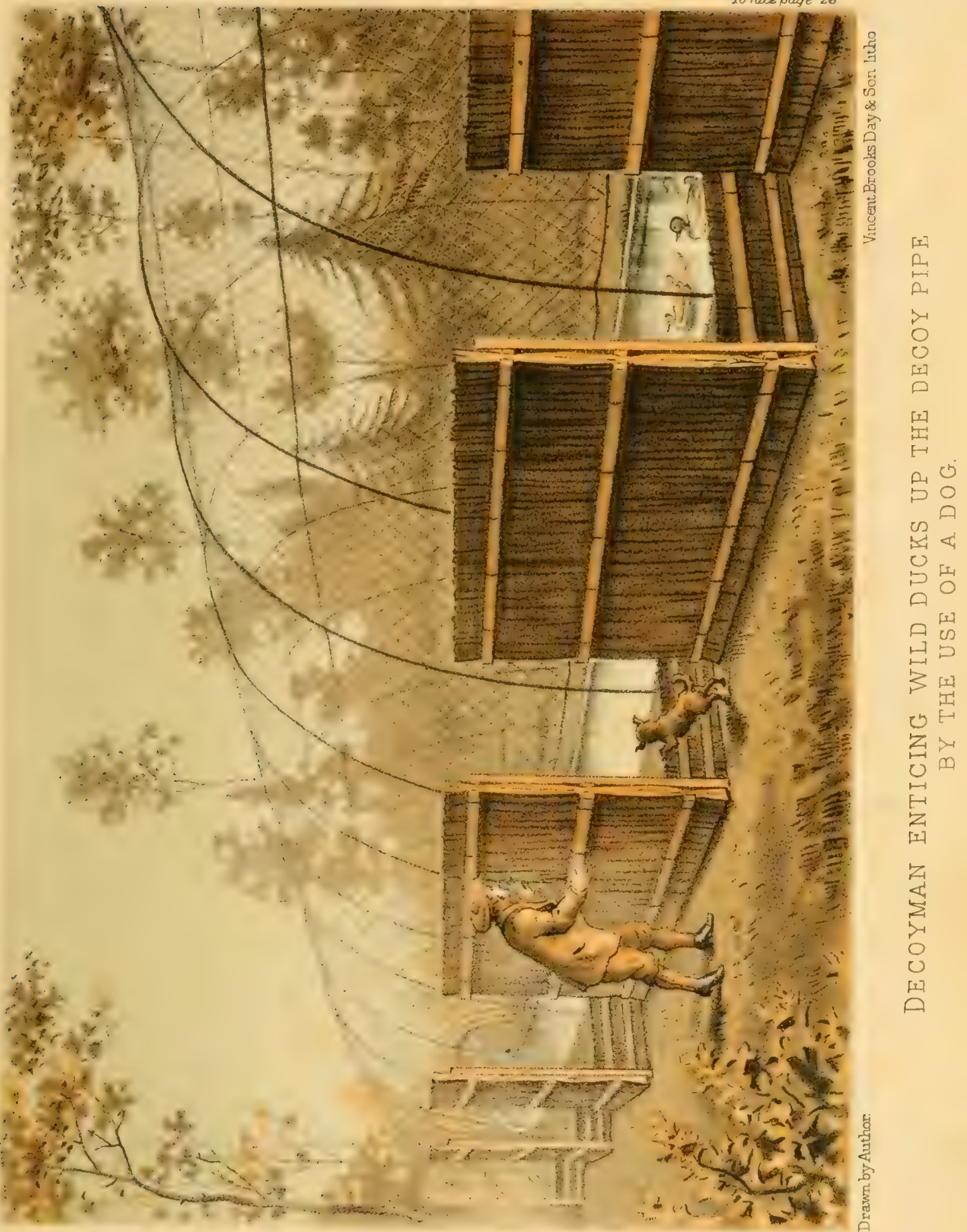





\section{FEeding.}

Food is also used to attract the fowl far enough up the pipe to enable the Decoyman to cut off their retreat back again to the pond.

Feeding is one of the cleverest arts of the Decoyman, and one only learnt by long experience. The secret of it consists in just knowing how to give both the tame ducks, and the wild ones that are following them, as much grain as appeases their hunger for the moment, and the XEXT moment makes them wish for more. As long as the Decoyman can keep the bircls exactly in the right state of hunger, he has them, so to speak, under his thumb.

If too hungry, the tame ducks will rush away from the wild ones up) the pipe (who will then fail to follow). If not hungry to a certain extent, they will not come up, at all, or if they do, so slowly as to be of little use.

If the wild ducks get 100 much grain thrown them they will not follow with the tame birds up the pipe, but cluster round the foud and remain stationary: All this has to be attended to by the Decoyman when in the act of feeding.

Tame ducks and wild ducks shotild be so fed that they mingle together if possible, or at all erents swim stcadily up the pipe, whether together or separate.

So that the Decoyman as he wallis away from the birds towards the tail of the pipe and behind the screens, gradually, and inch by inch, by juclicious throwing of grain over the top of each screen in succession-not too much and not too little-draws the fowl after him. He continually peeps through the screens as he passes along their rear to see how matters are progressing in the pipe. Finally, he leads the birds a few yards under the net to the spot in the pipe at which he knows their retreat can be barred by his showing himself at its entrance.

If wild ducks are very hungry they will now and then swim up a pipe after the food without the Decoyman using the tame birds to lead the way, as the latter may be out of reach of his whistle across the pond.

- But usually some of the tame 1.)ecoys, who are generally paddling about the mouths of the pipes, swim up first, and first commence feeding on the grain thrown into the water, near the entrance of the pipe, by the Decoyman. But should there be none about, they soon catch sight of 
the falling grain, or see a wild duck feeding on it, else hear the Decoyman's low whistle, and so draw up from all directions.

The wild birds, after clue caution and a little consultation, begin feeding too, though at first very reservedly.

But they see the Decoy ducks regaling on good store, and in fact getting more than their share-why should they not join the feast?

So they do, timidly at first, it is true; then they wax bolder, for the food is unusual and good, and they are hungry.

Somehow or other the Decoy ducks and the grain are always just a little in front of them; they find they invariably have to paddle a few feet now and then to get their share, or else they are left out in the cold.

They do not feed very comfortably though, for the further they swim up the curious-looking cage, which is apparently open at both ends, the more they hesitate and drop backwards when the grain is eaten, and till it next appears.

However 'tis but a few yards behind them to open sky and water and assured safety. But their suspicions being ever latent, and now slightly aroused, they had better, they decide, retire, and let those foolish ducks (the tame ones), suffer any consequences that may ensue from so boldly exploring a place that does not at its best seem one a cautious duck should venture in so far.

Alas, it is too late! Retreat there is none. Forward! forward! anyhow and anywhere, rather than back to the pond and past the Decoyman, who has now suddenly appeared in their rear at the entrance to the pipe.

So on they drive into the fatal tunnel net, wherein they are taken just as before told, when a dog was lately used to the destruction of some of their relatives in another pipe hard by.

On the coast many more fowl are taken by feeding than by dogging. This is especially the case in regard to Wigeon. Wigeon visit the tidal banks nightly, that is if the Decoy they frequent by day is within a few miles of the sea or its estuaries.

If the tides cover the ooze banks longer than usual owing to an onshore wind, or they are much disturbed $b y$ the gunners through the night, they are unusually hungry the next day.

This is all in the Decoyman's favour, and he will more often feed tide- 
frequenting birds up the pipes owing to such causes than make them follow the dog. They are then too hungry to be curious. Wigeon at all times feed up a pipe better than they follow a dog.

On the other hand, if fowl are not hungry, as is commonly the case with inland Duck and Teal, when marshes and rivers and rich water meadows are near, then the $\operatorname{dog}$ is the most certain means of attracting their notice.

When feeding, throw the food from behind the screens over their tops, not only into the middle of the ditch, but as far also under the opposite bank of the pipe as possible, as the fowl will swim up more readily the further they are away from the screens.

On bright, fine diys fowl are brisk and on the qui aive. In dull, wet, or misty weather much the reverse. In the latter it often happens neither dog nor food will move them.

I have shown now both $\mathrm{dog}$ and food are used to entice the fowl up the pipes, I will now describe the effect the dog has on the birds themselves. Why they follow the food I have already explained.

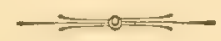

\section{The Effect of the Dog on the Ducks.}

Let us glance through the peep-hole of the screen that flanks the mouth of a pipe, on the sheltered side of the pond. See, the fowl are sleeping! Some idly jerking their bodies round and round in irregular twists, with an occasional stroke of one foot as they float on the water.

Some are sitting just beneath us on the banks near the entrance of the pipe with their heads tucked in, giving a wriggle of the bill now and then, as though to divide the feathers of the back, and so pillow their heads more cosily. Their eyes just show. Are they shut or open? or half open? 'Tis hard to say.

Never was there a more peaceful, innocent scene ; for surely, consider the ducks, this is pure, unalloyed happiness; no guns banging off, no foxes, no human destroyers. No, nothing, absolutely nothing, to disturb their repose so well earned after a toilsome night spent far away in search of food.

No cares of any kind, no need even of their usual sentries. Yet, 
perchance, they cannot help sadly reflecting on the fate of those poor ducks in distant places, who are forever pursued by men with dogs and guns; who, alas! can never enjoy real peace of mind, whether eating or sleeping, who .... . but what, in Fortune's name, was that? Up goes every head in an instant. The birds fastest asleep of all are on the alert as soon as any.

I saw nothing-did you? did you? Did you hear anything? is what, judging from their looks, fancy shapes into words for them as they stand or swim with stretched necks and glistening eyes peering towards the pipe and its screens.

Some even swim inquiringly a few feet in the direction of the supposed but doubtful "something moving."

Save a few suspicious old Mallards, who stand motionless and erect on the bank, all berin to settle to rest and sleep as before. Perhaps it was only a leaf settling down after all, or a harmless, though restless and so troublesome rabbit, or else.... There! there it is again-a fox! a fox !-no, a dog! Not a moment is to be lost, or we shall not see him plainly, or know what he is about.

The birds, poor silly creatures for this once! - not at any other time, rest assured-rush, yes scramble, through the water up the pipe right under the fatal netting. They must see what it means; a dog whisking into view, and then frisking out of sight again the next moment in such an extraordinary manner, must be examined at once. Such a chance may never occur again in a lifetime. Besides, it is such impudence on his part, and if all go together the disturber may be frightened farther away.

So think the ducks, especially as they see the tame Decoys swimming up the pipe also towards the dog, for they know that the appearance of the dog means food thrown to them by the Decoyman; thus they swim up in expectation of a meal.

The wild ducks pursue the dog with indignant rushes when he is in view; when he is out of sight they hesitate, and half turn round to go back.

But he constantly reappears, and is going farther and farther up alongside the pipe; so are the ducks in its ditch, both tame and wild. (Sce opposite page.)

But the wild birds have found out he is a very harmless kind of dog 


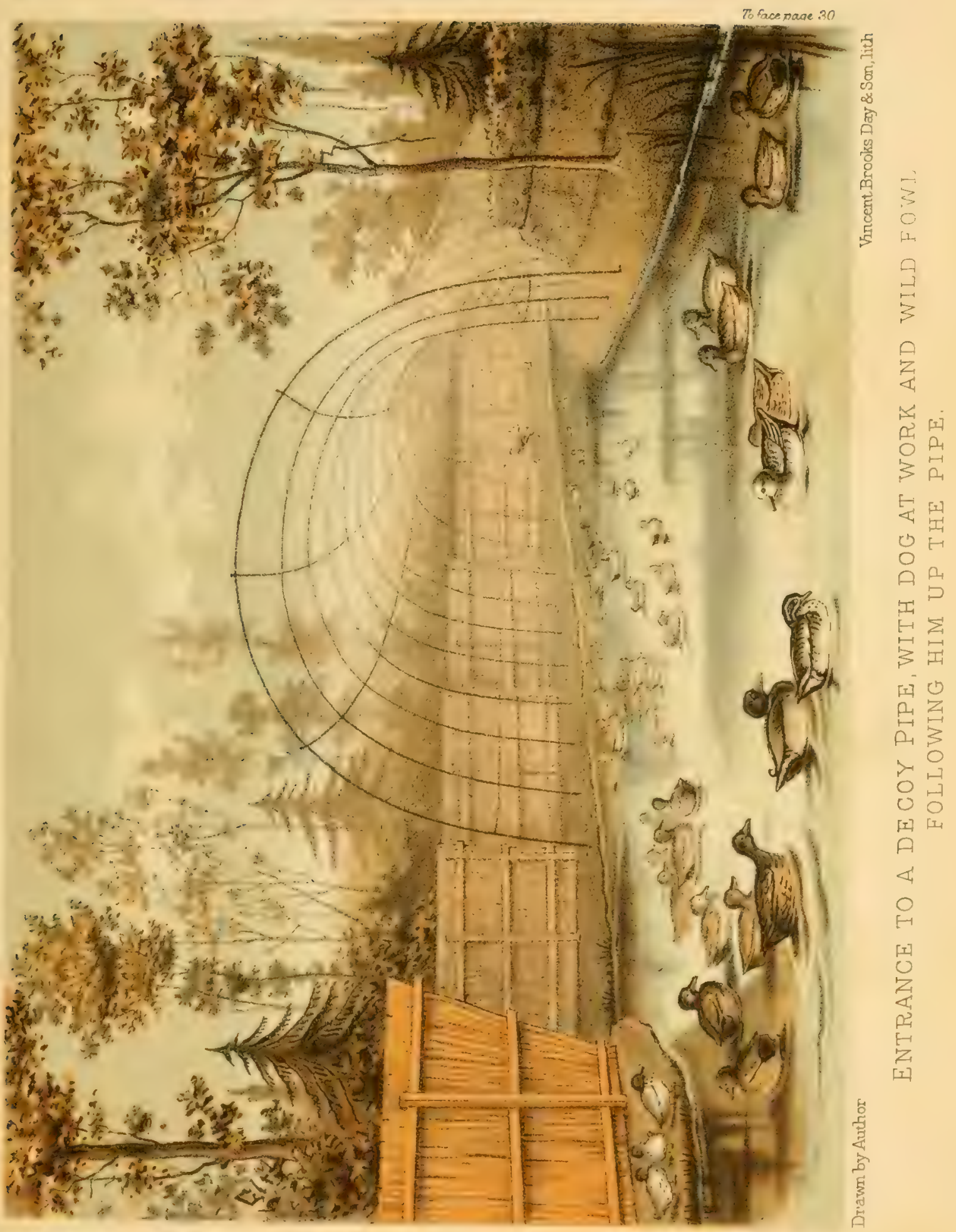


after all, certainly not a fox, so they decide to bother their heads no more about him. But -all of a moment, and as soon as their attention to and interest in the dog ceases, they realize that instead of clear sky above them, there is a netting that appears all round like a cage to their perplexed vision.

No time is to be lost, not a second. They see the open water some dozen yards or more behind them, from which they were allured by their curiosity, as well as by their indignation at that foolish little animal hopping about.

A trap! a trap! is the cry ; they instantly face about to return; a few seconds only and they are safe. No such luck-for what is this?

Between them and the entrance to the pond stands an awful form, and one that stops the way.

Death is to them preferable to passing within a few feet of a visible, a mortal danger, and one that every bird and beast shrinks from by instinct-" a human being!"

Yet there is one fortunate chance left, that is to fly up the pipe; for, after all, it is but a covered ditch, and to their eyes appears open at its far end. They, poor things! cannot see round the deceiving bend to where the pipe ends in the tunnel net, for aperture or escape there is none.

So within a few minutes of their sitting and swimining in safety outside the pipe, the unfortunate ducks are laid out in a row-dead--the result of a variety of passions, taken a cruel but useful advantage of by their enemy-man!

How the Decoyman drives the Birds up the Pipe, both when Dogging AND FEeding.

We have seen how the fowl follow the doy or the food up the pipes. As also described, the Decoyman suddenly appears, when the birds have reached a certain distance, and getting between them and the main pond, frightens them towards and into the tumnel net, wherein they are captured.

How the Decoyman reaches his station, that is the head shew, at the pipe's mouth without being perceived by the ducks he has lured into the pipe, has yet to be explained. 
I need scarcely say; did the ducks see him move past the openings between the screens, they would be out of the pipe in an instant. Nor would all the Lecoymen alise (ver persuade them into it again that day, perhaps not for a week, likely enough never.

There are two methods by which this important feat of driving up the fowl is managed.

Ist. A few feet behind the screens and dog-jumps, and in a line with them on the same curve,--that being the curve of the pipe-are back screens, 30 feet long.

These back screens consist of three only, and at their ends they also overlap.

The divisions between them allow a man to pass to their rear easily and quickly.

These openings are just opposite the spots in the ditch at which, when the ducks have been lured so far, they are far enough to drive up the pipe.

When the Decoyman has succeeded in enticing them this very necessary distance, he that instant steps backwards between the back screens and so races unobserved to the shew place at the mouth of the pipe. Just as he turns to leave the pipe, he throws into it, over the screen in front of him, his last handful of grain, or urges his dog over the jump and round its front, according as he happens to be dogying or feeding. If, when the Decoyman reaches his show place, the fowl are still above him, as of course they should be, up the pipe they are sure to go, as they think to save their lives. If the birds are a good way up the pipe the Decoyman need not go all the way to the hearl shew place, but can appear behind the fowl at one of the dog-jumps.

But the Decoyman has to be very quick, for the moment the dog ceases working round the screens, or the supply of grain stops falling into the water, the birds very often are liable to beat a retreat by swimming down the pipe towards the pond from whence they came.

However, unless really alarmed, they can nearly always be intercepted in time and with their heads still pointing up the pipe, and consequently in the right direction for them to take wing.

2nd. The other method is precisely similar in its effect, and differs only in respect to the way the I ecoyman gets behind the birds when in the pipe. Instead of back screens a concealed path that leads circuitously to the head 
show place is formed a few yards in the rear of the screens. Along this path the Decoyman can run to the head show without his being cletected by the birds he is about to drive up the pipe (sce plan facing page 57).

As this is the more modern and simplest method, I will adhere to it in preference to the former one described, though the other arrangement may be sometimes necessary owing to the nature of the ground.

There is one serious and frequent error made in Decoys by inexperienced Decoymen.

That is just not to lure the fowl quite far enough.

The extra yard or two is of the greatest value, and tells a clever manipulator at once. Such a one will alwaj's lure the fowl three or four yards under the net before attempting to drive them.

If the fowl are brought up the pile a I.ITTIE short of the necessary distance, the effect is, that when the Decoyman arrives at the head show place, they are often almost out of the pipe again. Some of them will then fly back to the pond, as it appears so close, at any hazard, and so spread alarm right and left to what have hitherto bec'n unsuspecting fowl.

As already said, the Decoyman endeavours to decoy the birds up the pipe step by step, inch by inch, inspecting them as they progress, through his peep-holes in the screens. Sometimes, however, he has to gallop, as it were, behind the screens to keep forward of the ducks, so furiously will now and again eagrer, unsuspicious fowl follow up the food or chase the dog.

But at most times it is only by very judicious management that he persuades them to follow dog or food up the pipe, and even then they are always on the point of retiring.

It is just at the moment they hesitate he always uses his best efforts to make them come but one yard farther, and that one yard may be all he wants to ensure their capture.

It is a question of a difficult and disputed persuasion from first to last - a much discussed argument between man and birds.

"Are we safe in coming so far into this cage?" quoth the ducks. "You are," says the Decoyman behind the screens; "so do come a little farther, I entreat you."

If the Decoyman has an assistant, the latter lies well concealed within easy reach of the head show place. On the fowl being enticed far enough 
under the net, the Decoyman that moment, and without stopping his manœuvres, makes a signal by raising his arm.

His assistant then shows himself instantly, first at the head show place, and up go the birds, and next as he runs from screen to screen, appearing over the dog-jumps between each as he does so, thus he finally urges them on into the tunnel net.

This is the quickest and safest way to act if large takes of fowl are on hand, or the birds are very shy. Should the Decoyman, however, be alone, he, as before shown, runs along the concealed path to the head show, or till he gets well behind the birds in the pipe. He then acts as above described of his assistant, and as seen in the illustration opposite.

At all times two men are necessary if the Decoy be a large one, as the assistant's services come in useful in many ways. In a small Decoy, such as that given facing page 55, any intelligent keeper can work and keep it in order singlehanded. 
To face page 34

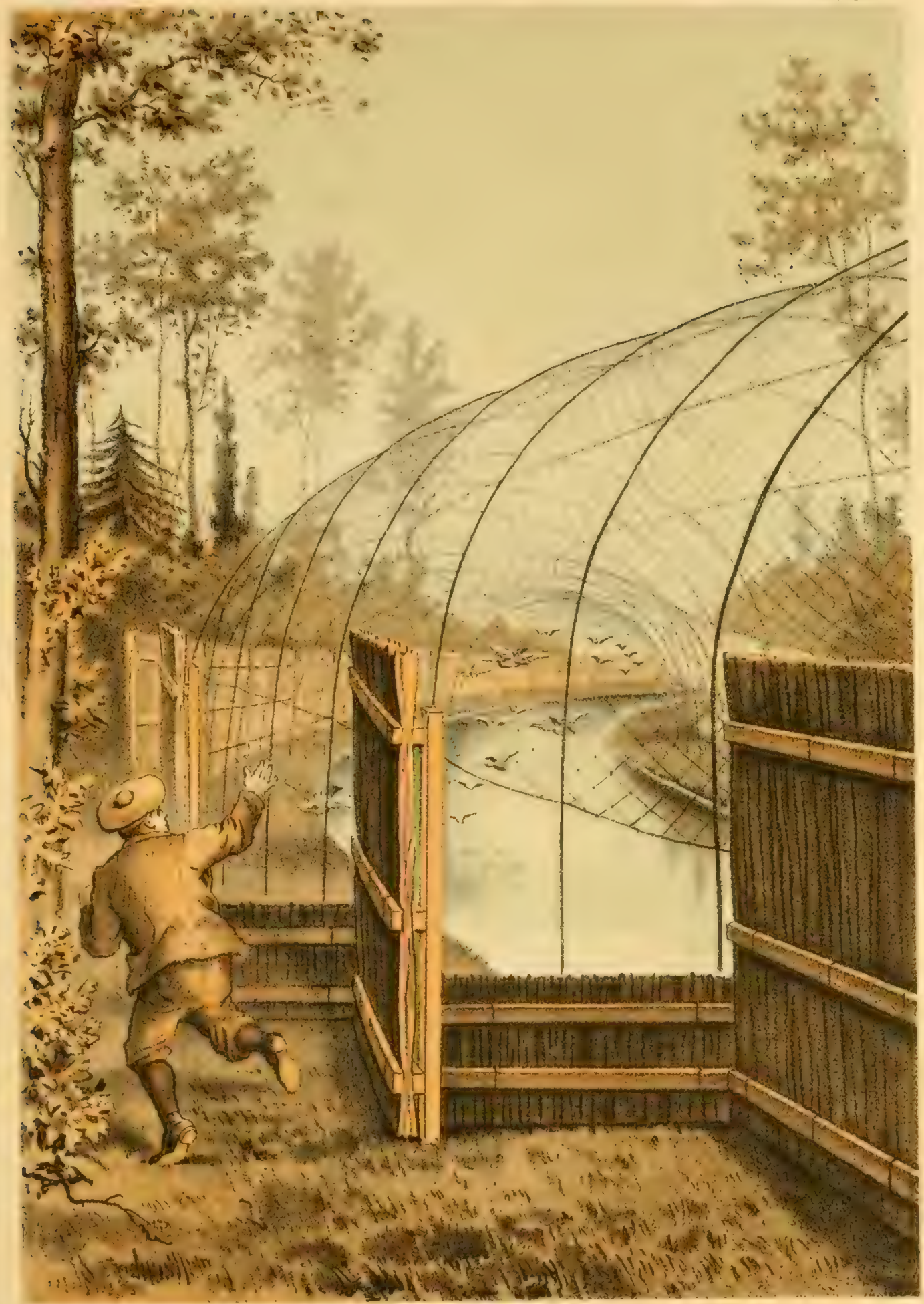

Drawn by Author.

Vincent Brooks Day \& Sorluth

DECOYMAN DRIVING WILD DUCK UP THE PIPE 



\section{CHAPTER III.}

\section{The Construction of a Decoy.}

The Pipes.-Truly the most important belongings to a Decoy; for in these the actual catching of the ducks takes place, after the latter have in the first instance been attracted to the main pond outside them. A Decoy is like an organ, it cannot be played on till the pipes are perfected.

To cut the ditch of a Decoy pipe properly requires careful staking out beforehand. How to do this is shown in plan facing page 36.

It will be seen by looking at the plans of a Decoy pipe, that the first hoop, i.e., head of net, is placed 9 yards above the head show place.

That the ditch under the first hoop is $21 \mathrm{ft}$. across; under the hoop at the first bend the ditch is $16 \mathrm{ft}$. wide: under the hoop at the last corner where the screens stop, Io ft.; at the extreme end $2 \mathrm{ft}$.

Let the pipes be large, airy, and light, and without any trees or underwood hanging over them.

If they are closed in by foliagre they will give the duclis the idea that they are dark, and so unsafe, cages, and not to be explored at any cost, whatever be the temptations and inducements put before their eyes.

Nothing will ever persuade ducks to swim freely up into a dim uncertainty, into an apparent danger, for such a dark pipe appears to their timid minds.

If they are at times persuaded to enter a dark pipe, they will only go up it a short distance and always with disappointing hesitation. They rarely advance in such a pipe far enough to be caught-- by being driven forward, or, if driven, they will often turn about and tly out, even past the Decoyman.

No, the pipes must be bright and open to the sky, and stand clear of trees other than shrubs or low brushwood.

From the first elbow of the pipe on its screen side, the adjoining land 
should be clear of growth other than low shrubs, from the second elbow grass should extend on both sides (see plan facing page 57).

This is very important, as then, when the ducks are frightened up by the Decoyman at the show place, they do not hesitate to follow on round the bend of the pipe. That is, if they see plenty of sky before them instead of a dark wall of trees.

So bear in mind that the delusion of an open space for the birds to escape through is immensely assisted by there being plenty of light in front of, and from the bend of, the pipe, and on beyond its tail. As Decoymen say, to drive ducks well the latter must see "out of doors."

When a pipe is spoken of as the "North" or the "East" pipe, it does not mean that the said pipes point due North or due East.

It certainly implies that they run in those directions, but the true implication is that the north pipe is the one that can be best worked with a northerly wind, the east pipe with an easterly wind, and so forth.

The Hoops that arch over the ditch should be of round iron. Flat ones stand a weight of snow better if placed edgreways, but then have a heavy appearance.

They may be $I$ in. in diameter for the first twelve hoops, then $\frac{7}{8}$ up to the last bend of the pipe, that is for the next fourteen hoops.

From thence to the tail end $\frac{3}{4}$ of an inch only.

The hoops are spaced all along the pipe its entire length $5 \mathrm{ft}$. apart on its outside curve. On its inside these distances vary a little to suit its bend.

The head or first hoop can be $15 \mathrm{ft}$. high above the water.

The hoop at the first bend $12 \mathrm{ft}$. high ; and at the second bend, that is opposite the last screen, $9 \mathrm{ft}$. The last hoop of all $2 \mathrm{ft}$.

These three hoops will span from foot to foot respectively:- $27 \mathrm{ft}$. ; $20 \mathrm{ft}$; $\mathrm{I} 3 \mathrm{ft}$. ; and $2 \mathrm{ft}$. The round of the first hoop is 46 to $47 \mathrm{ft}$., and all the others correspond in outline.

These dimensions are for a full-sized pipe, the cutting of which I have just described, but a pipe MAY be a foot or two less in width at the entrance if the nature of the ground necessitates an alteration in favour of a nar- 


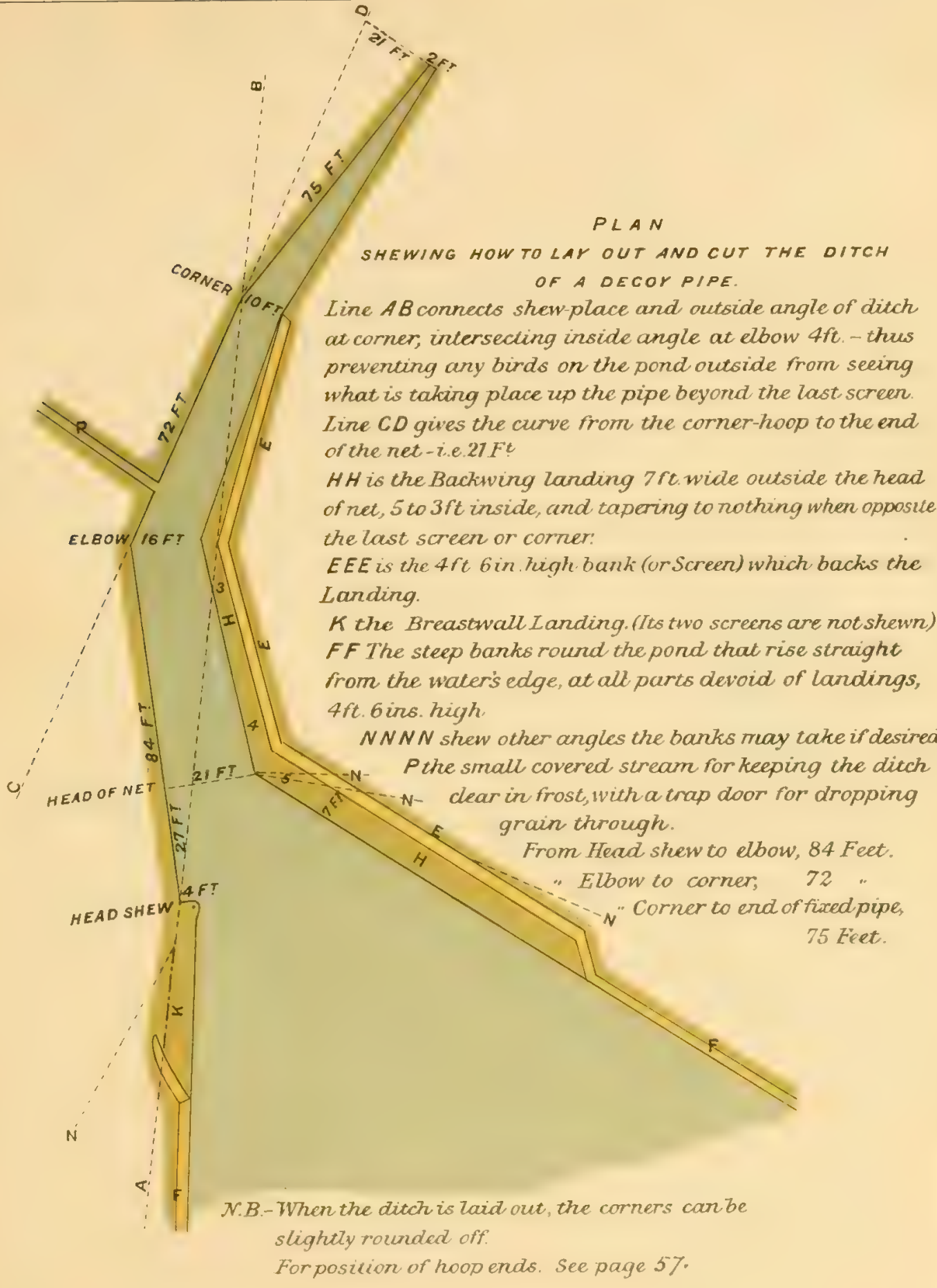



rower and a shorter pipe. The hoops will in this case be of course smaller in every way.

The larger hoops can be in three pieces, the smaller in two, and may be welded together on the ground, or else previously jointed and fitted for bolts. The last six or eight hoops to be in one length each.

When setting up the hoops first fix the head hoop and the ones at the first and second bend, and connect them with a string at their summits as a guide to the height of the intervening ones. Then treat the hoop opposite the last screen and the tail end hoop in a similar way.

The hoop ends will require sinking $\mathrm{I} 2 \mathrm{in}$. to $\mathrm{I} 8 \mathrm{in}$. in oak blocks 2 to

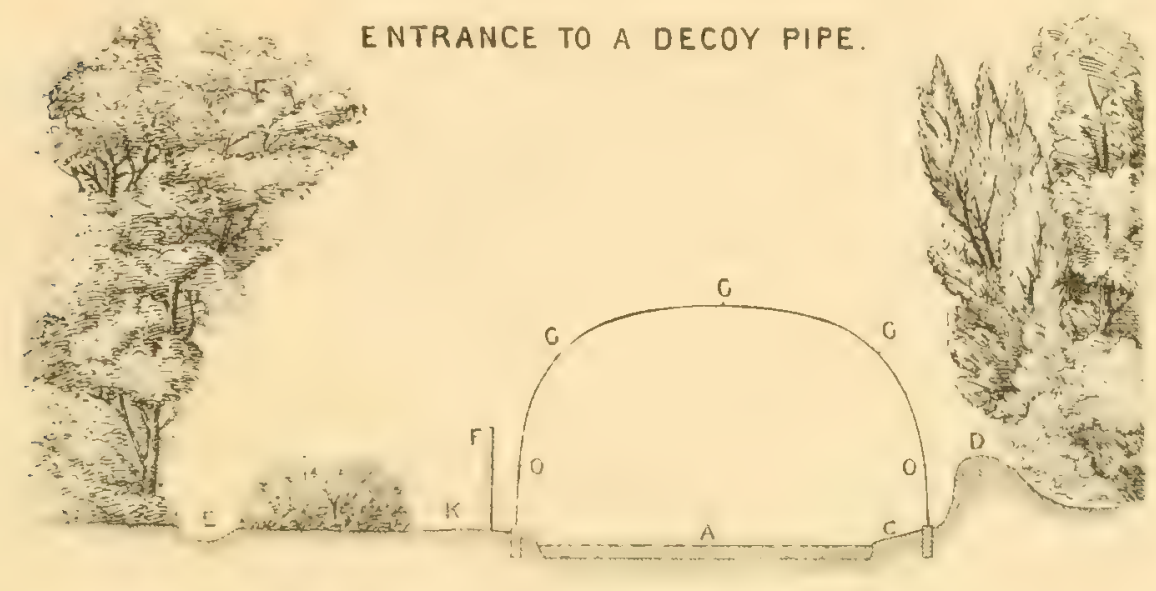

SCAI.E $\frac{1}{T^{\prime}}$ IN $=I$ FT.

A, Water. C, C, C, Ridge Trees. D, Bank. E, Path. F, Scrien. G, Landing. K, Smooth Turf. o, o, Height of Net at First Hoop.

$3 \mathrm{ft}$ long by $6 \mathrm{in}$. square. On the outside curve of the pipe the centre of these supports may be $2 \mathrm{ft}$. from the water's edge, on the inside 3 to $4 \mathrm{ft}$. distant according as the hoops narrow in their span (set plan facing page 57). From opposite the last screen they can be as close to the water's edge as possible on both sides. The top of the arches should be somewhat flat, and the first hoop should lean slightly forward. The hoops are held steady by three ridge-trees of $\mathrm{I} \frac{3}{4} \times \mathrm{I}$ in. strips of clean sound wood, running their entire length and firmly lashed, or, what is more permanent, by means of flat iron bars rounded on the outside, $\mathrm{I}$ in. $\times \frac{1}{3}$ in. and bolted to the hoops. (Scc cut above c, c, c.) The first hoop may require wire stays and posts to hold it securely. 
From the first hoop to the last the drop, which should be very regular, is about $4 \mathrm{in}$. each at their summits, and their span from 6 in. to 8 in. less as they follow along the pipe.

The Netting that covers the hoops should not reach within $4 \mathrm{ft}$. of the ground at the entrance of the pipe on either side (see cut "Entrance to a Decoy Pipe," page 37). It can be lashed to a stout wire or light iron rod running along from hoop to hoop.

A little farther up the pipe these gaps may be decreased by the netting and rod being brought lower down, by 6 inches or so, till they finally slope down on each side to the ground when level with the last screen, and so completely close the pipe from thence to its extremity, leaving no opening whatever for a bird to escape through.

These apertures in the net of the pipe all along the front of the screens and opposite to them enable the ducks to view the antics of the dog the more plainly and give the pipe a less confined look, especially at its entrance.

The birds never attempt to escape through them, however hard pressed.

The net (a diamond mesh) should be of best handspun hemp well coated with Stockholm tar, $\frac{1}{8}$ in. thick to the first bend of the pipe from its mouth; from thence to the tail end of one-third smaller material. If too thin the ducks, when driven, will try to burst up skyward, instead of following the length of the pipe as they should do. I do not approve of wire, though more lasting, as in a strong breeze it sings a tune, and I have often failed to catch ducks for no other reason.

If a grood many fowl get into a wire-covered pipe, some will damage and cut themselves against it badly, besides sending their feathers in all directions floating down the pipe, a sight not unremarked on by uncaught birds. I have even seen the body of a bird killed by wire drift into the pond and cause great mischief.

Wire is also very cumbersome to fix or handle. The mesh of the net can be 4 inches across, from the entrance of the pipe to the first bend, or large enough to just not allow a duck through it with folded wings, and then diminishing to 3 inches till the last screen is reached; from thence to the tail end 2 inches, or small enough to prevent a Teal from squeezing through. 
The ditch under the netting with the water in it ends $6 \mathrm{ft}$. short of where the fixed pipe terminates, and is sloped up dry with sods into the mouth of the tunnel net.

Then comes the tunnel net ( 44 feet to 15 feet in length).

It takes on and off easily, so that when it has captive ducks in it, it can be at once detached and each bird fished out and killed separately and safely. The head hoop of the tunnel net, it will be seen, slides into upright posts, with deep cut slots, placed at the end of the fixed pipe. Its hoops, all of a size ( 2 feet in diameter), are made of $\frac{1}{2}$-in. iron.

The tunnel net is pegged out straight when in use.

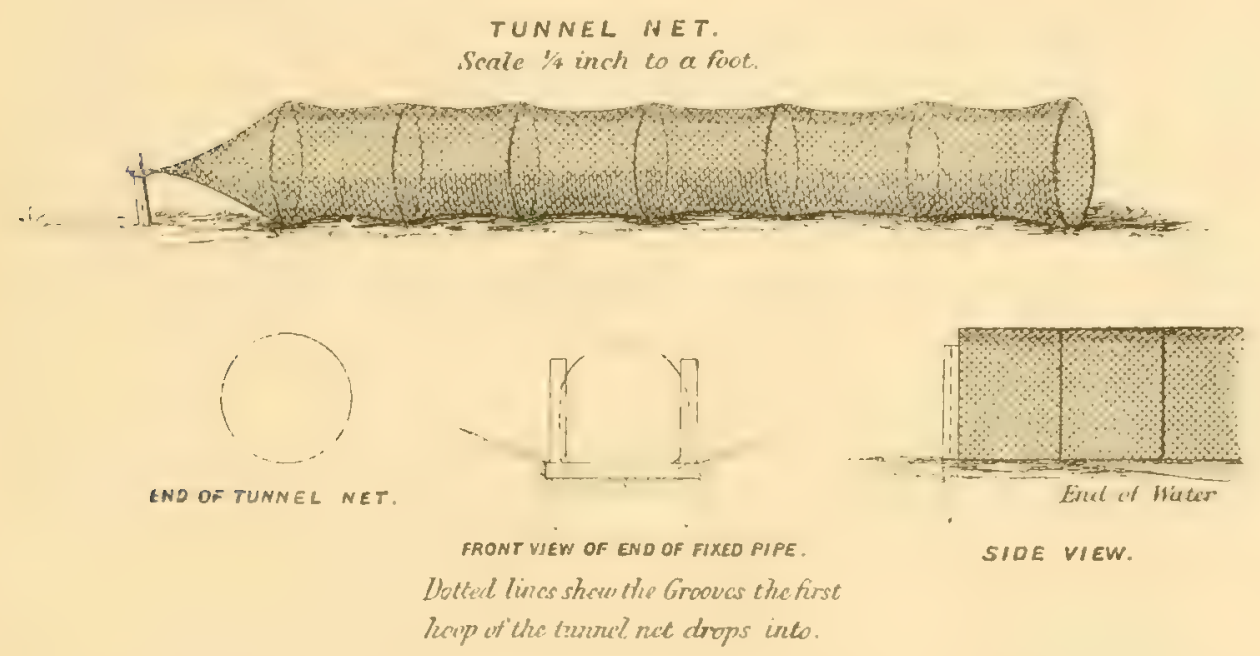

The netting of a Decoy-pipe is usually in three pieces, viz. : the Screen, the Elbow, and the Tail Net. The netting when being tarred, can have some linseed oil added to it to keep it soft and pliable. It will require tarring every three years.

It is a convenient plan to run a low board three or four inches above grouni on both sides of the pipe from hoop to hoop, and secured to the latter, from the last screen to the end of the pipe. To this board the net can be readily and securely hitched, if an hooks be driven into it at short intervals. It can then too be easily removed for repairs, or to put in store during the summer, as should be done, and will not so soon decay at its edges. 
The Pond.- That is the "Decoy Pond" in other words, and on the tranquil waters of which the wild ducks first alight. They are attracted by its peaceful seclusion, as well as by the sight and call of the tame ducks that are always on it for the purpose of allurement.

The pipes the wild ducks know nothing about, till they are enticed therein, and captured thereby.

A Decoy pond seldom exceeds from two to four acres, the usual size. being from one to two acres.

The best size is $1 \frac{1}{4}$ acres irrespective of pipes.

The depth $2 \frac{1}{2}$ to $3 \mathrm{ft}$. and slelving to $2 \mathrm{ft}$. at the edges.

Sometimes l tecoys (so called) consist of large lakes of 20 to 30 acres, such as at IVretham and Fritton, and was the case at Ranworth, Narford, and a few other places.

The pipes on these large pieces of water at times answer very well, but such can scarcely be treated of as proper Decoys-rather as Decoypipes attached to lakes.

The pipes in such cases are usually grouped at one end of a large piece of water, or round a sheltered bay. But these Decoy's do not take anything near the same proportion of fowl to the numbers on the water that a small Decoy will do. The reason is that the hirds so frequently sit out in the open far beyond the reach of the Decoyman's attractions.

The Water Supply of a Decoy ought to flow in and out clear of the piper. It should nevertheless, by means of small channels and sluices, be arranged to wash down the best pipe or pipes at will.

By the best I mean those that catch best, or that fowl frequent the locality of most, which is after all the same thing.

The north or east pipe, or both, may have the preference of a flow of water. They are the one's most frequently choked with ice in hard weather, and in severe frost it must be borne in mind most fowl arrive in a Decoy if kept more or less free from ice. It is very necessary therefore to keep these pipes with open water in them at their entrances.

The flow of water need only be led in at the first bend of a pipe.

Even a small current will serve to carry down the food much farther 
and quicker than is the case in still water, and so set the fowl on the feed well out into the pond, and perhaps cause a capture when not otherwise expected.

A strong flow through a pipe, by means of storage water and a sluice, that can be kept for emergencies, such as during a hard frost, is invaluable. It will prevent ice forming at the pipes' mouths.

On and near open water, with hard frost all round, the fowl invariably crowd and gather, and when this occurs, as it should, near the entrance to a pipe, the birds are handy to the Decoyman and his enticements. Ducks, too, will invariably swim more freely against even a slight stream in a pipe, than if in still water.

A Decoy pond is, if well made, so shaped that whatever part of it the ducks frequent from time to time, or day to day, they are more or less within the "embouchure" of a pipe's mouth.

This of course would not be the case if they remained always in the middle of the pond in open water. But such is not their habit, as they prefer the banks and sheltered corners.

Tine Landings And Banks of the Decoy pond require considerable care in their arrangement. All Decoys require landings, or, as the Decoymen term it, "chairs for the ducks to sit down on."

The birds cannot pass all their time swimming, and it may be said that they frequent the Decoy almost as much for the accommodation of its landings, on which they plume and sleep, as for the use of its waters to drink and wash in.

In a Decoy with some half a dozen pipes, the distance from the entrance of one pipe to that of the next is comparatively short, so that wherever the fowl happen to rest between the two pipes they are in working distance of one or the other; but if there be but three or four pipes, the edges of the pond will require to be more shut off from the fowl, so as to oblige them to land only near the pipes.

It will be seen in the plans that the shores of a Decoy are formed so as to slide or incline towards either one pipe or another. In a Decoy there should be a steep solidly built bank 4 to 5 feet ligh at all parts of the pond and rising ahruptly from the water's colge, save where the landings 
are made that flank the pipes' mouths, these resting-places having banks also at the back of them.* (See plan opposite page 55.)

This steep bank prevents the fowl from resting on any part of the Decoy edges, save on the landings near the pipes.

If a bank of this height cannot be arranged, then a continuous $4 \mathrm{ft}$. reed or wood fence can be placed instead all round the water's edge of the pond, and behind the landings.

It is very important that the chicf places the fowl should be encouraged to sit on, be just outside the entrances to the various pipes, and at least 25 yards in length by 7 feet wide on the off-side of the pipe outside the head hoop) (i.c., the back wing landing), and 20 yards in length by \& feet wide on the screen side of the entrance to the pipe beyond the head show place, the latter being the breast-wall landing ( see plan facing page 55).

If the fowl bank well, they are sure to have plenty of companions close by them in the water, or half in and half out of it. So all are then conveniently placed to serve the Decoyman's ends.

To tempt the fowl to come ashore and rest on these particular landings, they must be level with the water's edge, nicely turfed, smooth, and evenly sloped, and larger in space just outside the mouths of the pipes than elscwher, and especially so, as I have just said, on the left-hand side of the pipe's entrance looking up it.

() n the opposite side of the pipe to the screens, it will be seen that the lack wing landing is continued up under the net itself till opposite the last screen (see plan facing pare 57). The reason is that the birds will often rest thereon, and when so found can be driven up without the use of the dog or food.

Alonir the screen side of the pipe no landing is necessary, nor is there space for such.

All landings must be well sheltered on their landward sides by screens or banks.

The fowl will select the weather, that is the sheltered, landings to rest

* Wherever the steep bank rises abruptly from the water a reed edge should be planted, ro ft. broad, and thus it will fringe the bank from the end of one landing to the end of the next one (see plan facing page 55). The bank tops should be planted with privet, both to increase their height, as well as to strengthen them. 
on; there the wind that protects them is just the one to work the pipe near which they are sitting so unsuspectingly.

Therefore on no part of the shores of a Decoy pond should there exist convenient resting-places for the birds except near the cintrances to each pipe, for the obvious reason that the Decoyman wants the fowl to lie within easy reach of any pipe or pipes when they do come ashore to re:t. The best pipes and landingrs should be placed to face the sun as much i... possible, for the fowl will always choose the warmest spots on which to sit and dry their plumage, especially the young birds whose feathers are not yet quite waterproof.

If a Decoy pond or its pipes be dug out of sandy soil, they will require all round their edges a twisted wattle fence, reaching firm the bed of the pond to the surface of the water to keep the sides from crumbling in.

To protect the Decoy pond from vermin, foxes, or disturbance senerally, a wire netting of 4 ft. hish above ground should be run round its outside and attached to substantial posts, with here and there a hand-gate, so that each pipe can be safely approached against the wind.

If a Decoy is in a large wood, this netting can be put insicle the wood and round the Decoy so as just to clear the tails of the pipes.

This protection is very necessary, as foxes play havoc with the tame Decoy ducks. Rabbits are also a great nuisance, as they burrow in and destroy the banks, as well as cause uneasiness to the wild ducks by frisling about and scampering ard rattling through the underwood.

If a Decoy is within sight of a road or houses, it will need on that sicle of it a $6 \mathrm{ft}$. high, close paling, and careful planting, to shut it in from outside view. A ditch can be dugs outside any protective paling, which makes the latter much less nesotiable to those who have mischicurous or curious tendencies. If a $6 \mathrm{ft}$. high park paling, spaced i in. apart and the lathes pointed, be placed round the Decoy, it will not only keet' out all trespassers, both men and animals, but will form one of the lest phensant aviaries possible. Evergreen privet is the thickest and quiclest srowing shrub to plant about a Decoy, or cin the hanks, besides being an cacellent shelter for game of all kinds. 


\section{The Scieens.}

As previously shown, these are the shelters that at all times hide the Decoyman from the ducks. This they do whether he be reconnoitring them in the first instance, or afterwards enticing them up the pipes with dog or food.

They should be $6 \mathrm{ft}$. high. If the Decoyman be over 6 feet tall he must sacrifice the comfort of an erect figure to the benefit of the Decoy, as very high screens give too much the idea of a suspicious enclosure to the pipe they flank.

The first screen, the one that reaches from the show place to the pipe's mouth, is $2 \mathrm{~S} \mathrm{ft}$. long, then all the others on towards the tunnel net may be i 2 feet. Eleven screens in all without the breast-wall screens.

The latter are $\mathrm{I} 8 \mathrm{ft}$. and $\mathrm{I} 2 \mathrm{ft}$. in length, and shelter the broad landing between them and the water's edge. Between these latter is the "Yackoop" (sce plan facing page 57). At the show place, under the screen that projects over the water, there is just space for the dog to run round, and so jump back to his master.

All the little screens or dog-jumps, that join the large screen ends, are $2 \mathrm{ft} 6 \mathrm{in}$. in height, and $2 \mathrm{ft} .6 \mathrm{in}$. wide across their openings, save the one at the head show, which is $3 \mathrm{ft} .6 \mathrm{in}$. wide.

Each tall screen has a peep-hole in it through the reeds, and this, as occasion demands, is kept open by a flat and pointed piece of lath-wood, $S$ inches in length by an inch wide; when no view of the ducks is required to be taken, the wedge of wood is left perpendicularly between the reeds, and the hole caused by turning it edgeways closes.

On twisting the wedge from side to side, a clear sight of the pipe and pond can be taken in any direction.

When setting up the screens fix their posts and rails first. The posts nearest to the edge of the water being about $2 \mathrm{ft}$. 10 in distant from the bank of the ditch, the farthest posts 5 to $6 \mathrm{ft}$., the $28 \mathrm{ft}$. screen being $2 \mathrm{ft}$. only from the water its entire length. The distances of some of the $12 \mathrm{ft}$. screen posts will vary a few inches as the curve of the pipe is followed. Be sure that each opening between the screens over the dog-jumps, as you move from the mouth of the pipe towards its tail, points fair and true up the ditch of water and the network of the pipe. 
The necessity of this arrangement is, that when the Decoyman appears at his first or head show place in front of the pipe's mouth, though the ducks start up the pipe, they might break back past him unless he stopped them. This he does by running to the next show place, i.e. dogjump.

So he goes quickly on from opening to opening till he sees that his appearance is driving the birds in their wild career towards the tunnel net at the tail of the pipe, as shown in the illustration facing page 34 .

It is obvious, therefore, that unless the openings between the screens faced stratirht up the pipe, the Decoyman could not properly continue to show himself behind the fowl in order to drive them up. In fact all that the fowl in the pipe can see between them and the advancing I)ecoyman, are the screens viewed edgeways. The same with the man and the ducks.

The space behind the screens should be carefully cleared of crackling twigs, or dry leaves, and plenty of sawdust strewn along a path is a sure safeguard against the noise of footfalls. The screens to be placed on smooth turf, which latter can extend $6 \mathrm{ft}$. in their rear.

Each $12 \mathrm{ft}$. working screen will require four oak stakes 4 in. $\times 2 \frac{1}{2} \mathrm{in}$, $9 \mathrm{ft}$. long, and $5 \mathrm{ft}$. $6 \mathrm{in}$. above ground, with three cross-bars $2 \frac{1}{4} \mathrm{in} . \times \frac{1}{4}$ in. nailed to them, as shown on next page.

The $28 \mathrm{ft}$. screen at the pipe's mouth will want eight similar posts and rails, the longest breast-wall screen six.

The reeds that cover the framework of posts and rails are placed roots at head and foot and points in the centre, and project 6 in. above the rails. They are tightly packed so as to lie nice and level.

The screens when in course of construction will each require two men, so as to pass the tying cord through from one side to the other by means of a I ft. long, wooden needle.

Three thinner laths, called tying laths, $\mathrm{I} \frac{1}{4} \times 2$ in. will be also wanted for each screen, to hold the reed firmly, and between which and the larger fixed laths the reeds are secured by lashing the laths togrether through and through. (See next page.)

The reeds are pressed side by side from one end of the screen to the other, so that not a chink of light can be seen between them.

The posts of the screens project on their pipe side. The dog-jumps have four laths, two to each side, nailed to the posts of the screens they 
connect ( $e^{\prime}$ full-page illustration facing page 34 ), and these are lashed just as are the lathes of the taller screens.

When making the screens the back or thin laths are tied loosely at first on to the fixed rails, and as the reeds are wedged in between they are secured by the two sets of rails being lashed tight together at $\mathrm{I} f \mathrm{ft}$. intervals. The reeds are placed as level as possible at the top of the screen when

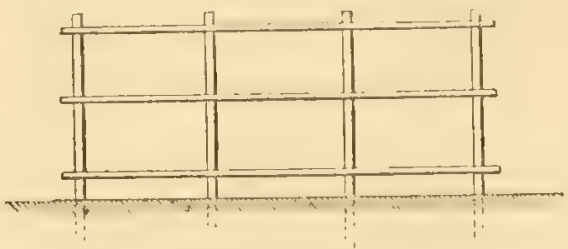

FRAMEWORK OF A SCREEN.

it is leing made, and then tapped down in line with a flat board the size and shape of a tennis racquet, but larger.

The Decoyman or assistant, if the screens are well arranged in "echelon," should be able to pass from the tail end of the pipe to its entrance, or visit any particular screen to take a survey down the pipe

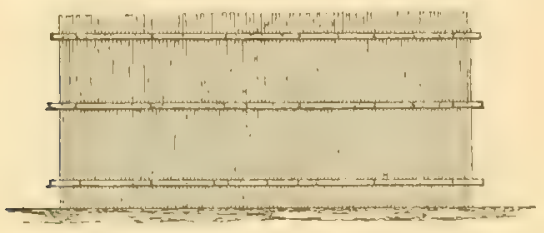

REAR OF A SCREEN, SHOWING TYING LATHES.

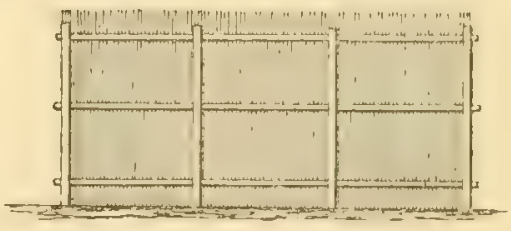

FRONT OF A SCREEN.

without being perceived by any fowl below him in it, or on the pond. He should also be able to show himself to, and so drive up, any fowl in the pipe without his action being perceived by other birds on the main pond. For this reason the screen at the head show projects over the water.* For arrangement of screens see zigzag lines, $\mathrm{P}, \mathrm{P}, \mathrm{P}$, on folding plan facing page 57.

* The reeds should be cut and stored in March when dead and dry. They are about $6 \mathrm{ft}$. high, round and feathered, and grow in the fen country in profusion. If reeds cannot be obtained, straw may be substituted, but it is never so satisfactory. 
The Teme Decoy' Ducks.-It is often imagined, by those isnorant of Decoying, that the tame Decoys act a part, and are aware that they are used to deceive the wild ducks.

Such is not the case, they are perfectly innocent of the nefarious uses they are put to by the Decoyman.

They merely obey their own instincts. If their wild brethren follow them, the latter must look after themselves. It is no affair of the tame ducks.

As they never suffer any harm, the Decoy ducks sce nothing wrong or suspicious about the Decoy or the pipes.

If the dog appears from behind the screens they swim up to him: they know him well, he is an old friencl. The reason they follow him is because, whenever he shows, they know grain is to be found in the pipe, thrown by the Decoyman from behind his screens. So when they see the dog they know that food is forthcoming.

In the same way they are ever ready to swim up a pipe for grain thrown into it at any time, whether they see the dog or not.

They are always hungry during the day, as they are only fed regularly in the evening when the wild ducks have left the Decoy for the night in search of food.

The Decoy ducks are taught to paddle surely and steadily up any pipe required, feeding meantime on the grain thrown to them from behind the screens. They are always fed in the fipe itself, and only get a good meal in the evening, as I have said. They soon learn to swim up a pipe fearlessly. During the day they require judicious feeding. For, as before pointed out, if too hungry they will rush up the pipe after the food, or to the Decoyman's whistle, with such vehemence as to cause alarm to the wild birds.

If too well fed they will fail to come at all, or so sluggishly as to be of no use in decoying their wild brethren.

The low whistle of the Decoyman should bring the Decoy ducks to obey his wishes from any part of the pond, that is, if he feeds them as they should be fed.

The tame ducks can number from 20 to 30 , and the best are a cross between wild ducks and small brown farmyard.

Save four or five at most, avoid pure bred call-ducks, white or brown ; they are too noisy. 
They also go through so many antics, such as splashing, chasing, and fighting, thus disturbing the wild ducks, and making them loth to follow birds that appear so bold and careless.

Call-ducks are very useful, however, to keep in a new Decoy the first year, in order to get a lead of fowl to the pond. Their noisy cries will bring down birds passing over at a great height, but for actual use in the pipes they are not successful.

Tame reared wild ducks are also to be strictly excluded from a Decoy.

Their nature is far too cunning.

They will often stand guard over the entrance of a pipe, and though feeding on the grain as it drifts down, will act as sentries, and not allow a bird to enter under the net.

They give some low warning note, or make some, I presume, duckunderstood gesture suggestive of danger.

When the wild ducks rise in fright, and are driven up a pipe, the tame ducks that helped to lead the way are not alarmed, but swim quietly down the pipe again. As THEY know the Decoyman well, and as he does THEM no harm, they cannot understand why the wild birds should be so alarmed by his appearance.

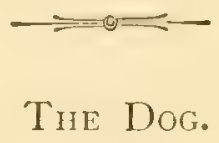

A bright intelligent little fellow, about a third smaller than a Fox, with a curly bushy tail if possible, and of a red or yellow colour.

A good Decoy dog is hard to find, but, when obtained, is invaluable.

He should do his work cheerfully above all things, and be well rewarded for doing it -at the time.

One wave of the hand or arm is enough, if the dog is properly trained, to urge him on his career over the jump and round the front of each screen consecutively, or round any screen that the Decoyman may wish.

Yet he needs do his work steadily all the same-I mean he must never fail at a critical moment. A turn towards the ducks following him, or a whimper would spoil all.

Two dogs of different colour may be kept in use, as it often happens, though the birds, will treat with contempt the one, the other will rouse them to follow him at once. 
A coloured cloth round the dog will sometimes move them when nothing else will.

So will a fox's skin strapped round him, with a trailing brush. But a dog will seldom work well with these additions. He feels he is mack a show of.

I have tried a cat, a ferret, and a rabbit. They all attract, but are next to impossible to manage.

I once bribed an organ-grinder to lend me his monkey. 'The fowl absolutely flew after him when first shown, but when he turned round and grinned at them they fled. When he sprang atop a screen and cracked the nuts I had tried to bribe him into acquiescence with, ending by scampering along the top of the pipe, every bird left the Decoy for the day. And no wonder.

Finally, the monkey tumbled into the Decoy; and nearly died from fright and cold, and I narrowly escaped having to replace him.

If a dog is shown very often, the wild ducks will get to know him too well, especially the old habitue's of the Decoy, the latter then taling but little notice of him. It is always the new-comers who are easiest taken in by a $\operatorname{dog}$ and his tricks; for to them he is an unusual sight. I know a friend who in vain tried his ordinary Decoy dogs, but without effect, as the fowl had become what Decoymen call-stale; " that is, they knew all about it, and refused to listen to the voice of the charmer.

As good luck would have it, a lady friend to whom the Decoy was being shown, had brought her pun with her. The pug was started near the mouth of the pipe, whilst his mistress signalled to him from near the tunnel net. By mere chance the dog; untutored in the way's of Decoying, started gamely over a couple of jumps, and round a screen or two. The wild ducks tore after him up the pipe at once, and a good catch was the result. Whether it was the curl of the pug's tail, or a very large bluck spot near it, or his quaint, well-fed appearance, can be only conjecture. At all events, the ducks evincel neither discretion nor hesitation on vicwing: him.

* Stale birds are those that have been a long time in a Decoy without being caught, and have grown cunning and cautious. Fowl fresh from the coast are easiest taken, and can be distinguished by the "high-water mark" to be seen on their breasts left lyy the salt water, and which soon washes off on their arrival in a Decoy. 
At Fritton Hall (see Fritton Decoy) there is a portrait of a large Newfoundland (?) which many years ago was a famous Decoy dog.

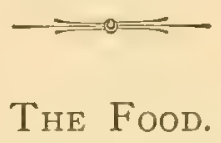

This must never be spared in a Decoy, and should be strewn about the landings and in the water near the pipes overnight. The wild birds soon spread the good news, and more and more fowl will collect in the pool in consequence of their being, as Decoymen say, "tethered by the tooth."

Decoymen profess to specially prepare the grain they use when feeding up the fowl, but it is more the way it is thrown and used than the actual food itself.

It is necessary that the first handfuls of food thrown in should be light and dry, that it may float well, and so attract the attention of the birds as it drifts along the surface of the water. Some Decoymen use bruised oats for this reason, when first commencing to feed in a pipe.

Buckwheat is as good as anything to use; also oats, with some hempseed oil sprinkled on them. Walt grains, or coombs," flavoured by aniseed, will sometimes draw fowl up a pipe when they refuse other food.

Hempseed or canary seed is also very attractive to wildfowl as a change, and especially so to Teal. Decoymen also place great faith in what is well known in the fens as "Willow-weed." The Essex men prefer it to any other food, especially for Wigeon, and take no little trouble to obtain it from Norfolk or Lincoln. This weed is Polygonum persicaria (spotted knot-grass). It grows in fenny soil among the corn, and has a small black triangular-shaped seed, and a black horseshoe patch on its leaves. Farmers when threshing often save it to feed their poultry and pigeons with.

But Ducks will feed on barley, wheat, or maize, in my experience, as well as on anything else, and some acorns thrown into and near the entrance of the pipes overnight is an adminable device, for there is no stronger attraction to wild duck than acorns.

* "Coombs" are the sprouted germs of the barley which are screened off the malt after drying, and which, owing to their sweetness, wildfowl are very fond of. 


\section{CHAPTER IV.}

Some Final and General Directions in the Management of a Decoy, and in Catching the Duchs.

I will first speak of the wind as being the most important subject connected with the working of a Decoy.

Never try to work a pipe straight down and out of the entrance of which, or from the screens to the entrance, or from yourself when walking behind the screens, to the ducks about its entrance, the wind blows.

If luck is ' 'ery' much in your favour, this rule may at a pinch sometimes be discarded, though always at a risk.

It is never safe to act thus, for a failure is courted if you stand or move in a Decoy with such keen-scented birds as wild ducks dead to leeward of you.

This rule applies whether you have or have not a piece of smouldering turf in use to conceal the smell of the breath or clothes.*

The diagram afterwards given shows the only winds with which to work a pipe really successfully (see p. 57). The arrows are drawn on the folding plan of the Decoy pipe to point up wind, and so show the direction it should blow from to work the pipe.

Outside every Decoy, on a mast, or else on the top of some tall tree hard by, should be fixed a weathercock, to indicate the tmac direction of the wind at the time it is wished to make a catch.

Remember the ducks when they rise invariably face the wind, and at all times incline to fly against it when first they are flushed.

Therefore, when you appear at the show place in order to drive the birds up the pipe, and the wind is blowing from the ducks to you, much

* In the fens of Lincolnshire turf was largely burnt before coal came into use, and it was supposed the wildfowl, being accustomed to its smell, did not mind it when used by the Decoymen to hide "their natural odour." 
is in your favour. They start the right way at once, and that is up the pipe. If the wind blow into a pipe's mouth, the ducks will fly against it when they first rise, and so often come out of the pipe, unless the ditch be so low and narrow as to be quite sheltered. Should such be the case, however, the pipe is a bad one in every way, both for enticing the birds up it, or for driving them when in it.

Ducks always swim head to wind if they can, as then their feathers do not ruffle as when they drift with it.

They also rest head to wind when on land for the same reason.

Hence, outside the pipe that the wind blows downwards and partly across, the birds are more or less facing its entrance. They are then near at hand to the Decoyman, and so readily perceive the dog when he appears, or food is thrown into the pipe.

This is the case whether they be the tame Decoys or the wild ducks.

On some occasions, such as in a strong breeze, the fowl will be seen resting just inside the pipe under its net on the landing opposite the screens.

Nany a grood catch is made by finding them there, and suddenly surprising them up the pipe by appearing behind them at the head show place.

For this chance alway's approach and reconnoitre a pipe carefully on first entering a Decoy, looking through the furthest screen from the pipe's mouth in the first instance, as then, if any fowl are in the ditch, they can be driven up by the Decoyman running round to the head show or one of the dog-jumps, and so getting behind them.

It should be carefully arranged in all Decoys that the wind can blow unchecked slantingly down the pipes from their offsides, opposite the screens-I mean the wind that is suitable to each pipe when it is worked.

If a bank of high trees are standing thickly over the screens, the wind recoils from them in a current, and so whirls into the pipe's mouth and pond. It will then, of course, carry your scent with it to the fowl, and quite spoil for the time any chance of a catch.

This is a frequent, though often unsuspected, cause of the failure of what may otherwise be an excellently planned pipe.

When approaching a Decoy, be careful to enter its precincts so as not to gret any fowl dead to leeward of you; for this reason four hand-gates 
need to be placed so that it can be entered on every side safely, and without alarming the fowl, whether they be in a pipe or on the pond. Do not try to decoy in a flat calm, a little wind is always necessary to success. It gathers the fowl off the centre of the pond about the sheltered pipes, and by rustling the herbage conceals footfalls. Besides, as I have said, the birds never drive well unless more or less heading the wind.

However anxious to make a catch, do not press the fowl too hard with your allurements - doing so only makes them suspicious. By waiting, a successful drive may result later in the day.

Eight, twelve, and four o'clock are the best times to try for a catch by feeding, three o'clock for the use of the dog.

It is not much use trying between ten and eleven o'clock in the day, as the fowl are by that time becoming sluggish after their night's flighting in search of food, and after a wash and drink prefer resting on the bank, or sleeping on the water.

At four o'clock they are beginning to feel hungry, as well as to move off the banks into the water previous to leaving the Decoy for the night, and are then more likely to feed up the pipes than at an earlier hour in the afternoon.

Avoid casting shadows on the water of the pipe between the dogjumps when in the act of Decoying. Such will certainly spoil a catch if the sun is low and behind the Decoyman, as may happen late in the afternoon.

If fowl are banked on the breast-wall landing and will not take notice of either dog or food, the former may be sent right among them over the dog-jump between the screens that flank them, into their midst.

The effect of this is to cause the ducks to scurry off the landing in great alarm, though as soon as they get into the water they face about and swim defiantly towards the dog as he disappears round the corner and behind the screen again.

They are then all on the alert, and will probably follow the dog under the net, as he is sent along from one screen to the other as usual up the side of the pipe.

I have before alluded to the necessity of keeping the mouths and the water outside the entrances of the pipes clear of ICE in a frost, especially. 
those pipes which, when the wind sets in during frost, suits as to working them-namely, the upwind pipes.

The ice need only be cleared a short distance inside the pipe; as far, in fact, as the point at which the fowl can be driven up from.

The ice clearing of a Decoy is a most unpleasant duty, but results usually well repay the trouble. It also requires considerable management to clear the ice properly. A grood deal can be done in thin ice by the use of a heavy pole and by rocking a boat. In thick the better way is to cut off large blocks, and then with a grapnel pull them under the solid sheet as the Decoyman stands on its verge. Several cracks with an axe and a side wedge or two will split the ice along from point to point.

It is no use clearing the ice early in the night, as it will only freeze again before the ducks return from their feeding grounds at dawn.

It will have to be done as soon before the fowl arrive in the morning as possible, say from six to seven o'clock.

A small flat boat, and a long iron-shod pole, needs be always at hand.

The boat can be lifted out of the water and hidden out of sight during the day, or, what is better, concealed in a boat harbour roofed with planks and turf.

Some extra grain can be thrown to the Decoy ducks (who will be hungrier than usual) during frost. By doing this judiciously, they will much assist, by their motions, in keeping the mouth of a favourable pipe for work clear of gathering ice.

If ice forms very quickly in still corners about the pipe by day, throw some good handfuls of grain on its surface. Then the weight of tame ducks, as well very often of the wild, will break it up and force through it. In a frost, at its commencement, when fowl have sought the rivers and marshes for fresh water, through being frozen out of their usual haunts, it is a judicious action, on one or two occasions only, to "rise" a Decoy (early in the morning) - that is, to frighten the birds away. By so doing they will presently return and bring many strangers with them.

Killing Birds. - This is a knack, requiring a certain amount of skill, that has to be learnt by a new Decoyman, and which consists in breaking the necks of the captured fowl artistically. It is a very necessary operation to learn, for nothing looks worse than half-strangled fowl fluttering about 



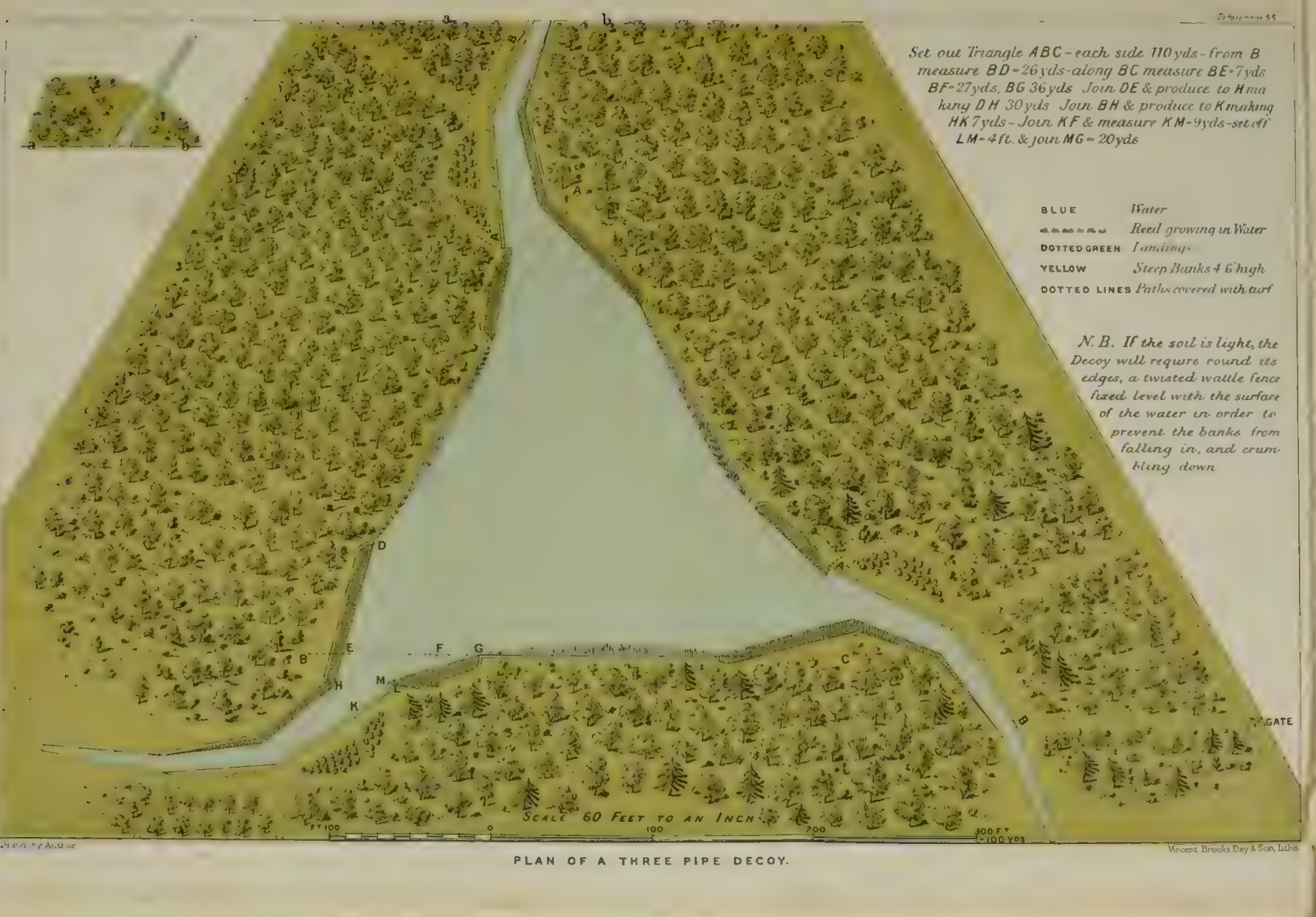


the ground. A half-killed bird escaping on to the pond will do great damage to the Decoy. This accident I have known occur more than once. The more expeditiously the fowl can be taken out of the tunnel net, and silenced, the better. The net should be dragged a little distance if many fowl are in it, so that their flutterings cannot by any possibility reach the hearing of the uncaught, but ever suspicious, birds on the Decoy pond.

The tunnel net can be held firmly between his knees by the Decoyman, as he takes out the captives one by one, kills them, and throws them on one side. (See page 22.)

But killing deftly is of importance, and can be best learnt from some practised Decoyman. The bird is pulled out of the tunnel by the neck, the neck is then twisted into a ring, and kept in that position with the left hand, whilst the right hand gives the dislocating jerk; all the work of an instant.

If live birds are wanted, as is often the case, their wings are crossed at the first joint, one being twisted behind and round the other, till they are securely put into a basket. They will not run, and have no power of flying, or even fluttering, when in this position.

I will next shortly criticize the more important of the plans of Decoys given throughout the book.

Eight-pipe Decoy (facing page I67). This Decoy is far too large, and has too many pipes for ordinary use. The more pipes, the more expense and trouble incurred. If fowl frequented a neighbourhood in vast numbers, as was the case when such fine Decoys existed, then it would be well adapted to catch extensively. But unless its takes reached an average total of 5,000 ducks annually, such an elaborate Decoy is quite unnecessary. A Decoy with only five pipes would in these days be quite large enough, even in the best preserved districts for wildfowl, and where they abound the most.

Six-pipe Decoy (facing page 122) (a seven would not answer or be symmetrical). This is a well-planned Decoy, it is true, but a five-pipe one would catch as many fowl.

The chief object of a Decoy is to have its pipes so that they will suit every wind; this a five will do as well as a six-pipe one. I may point out that in an eight-or six-pipe I lecoy, two pipes, or even three, may sometimes be worked with the same wind, thus giving, if fowl are present in 
great numbers, a much larger bag. But such immense congregations of fowl are not to be seen in these days anywhere in our islands.

Five-pipe Decoy. This is the Decoy I strongly recommend for any place where fowl are numcrous. It is a most convenient size, and very workable. Its pipes will suit every wind that blows. (See plan facing page 58.)

A Four-pipe Decoy (facing page 174). A very good one too, but I consider a three-pipe Decoy is just as good. Four pipes are not nearly so good as five if fowl be plentiful, and there is one pipe too many if birds are scarce.

I am now speaking of making a Decoy where nothing of the kind exists.

If the pool of water is ready to hand, then it may be easier and not more expensive to put four pipes to it than three, especially if it be a square pond, with corners adapted for the four pipes ready formed. The plan facing page 93 is also a good shape for a four-pipe Decoy, and has proved a very successful one too. It is of course an object to fit pipes to an existing pool to suit its present shape, and so save expense and labour as much as possible.

A Three-pipe Decoy (facing page 55). This is a capital plan, and more generally suitable than any other for a place where fowl are comparatively few.

It is inexpensive to make and work.

The pipes will suit almost every wind, quite enough so to catch several hundred fowl in the scason, or several thousand for that matter if they were a'ry abundant, as in days gone by. I therefore give a large plan of a three-pipe Decoy, by studying which, as well as the folding plan of a Decoy pipe on the next page, such a Decoy can easily be constructed.

A Two-pipe or One-pipe Decoy usually consists of a pond or lake with a pipe or pipes attached to it, and placed at its most favourable corner or end; that is, the one oftenest haunted by the birds. In this case the rest of the pond is little interfered with or remodelled, being merely kept quiet and secluded.

These plans are taken from some of our best Decoys, and which latter were made by the cleverest Decoymen who ever lived, and who knew more about Decoys, their working and construction, than any one before or after them. 

SCA I. .

he Inch 90 owo tont
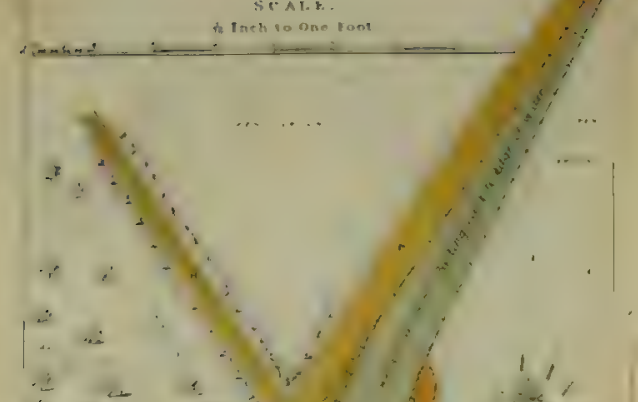
$\therefore \quad \therefore \quad \therefore \quad \therefore \quad \therefore$

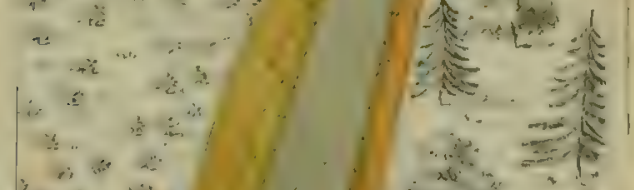

$\because \because \cdots$

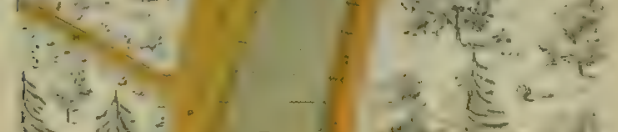

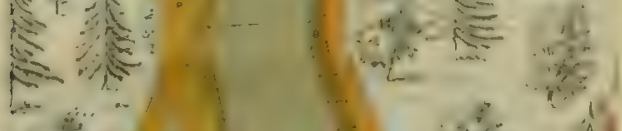

E

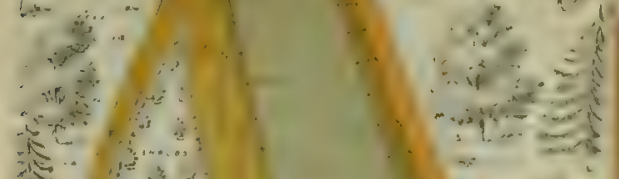

造

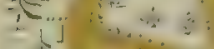

:

$\sum_{n=0}$

$\therefore=-\quad \therefore \cdots$

$\therefore$

$\therefore 2$ 这

$1, \ldots=0$

- $=1$

$\{\ldots+2 \leqslant$

in $\cdots$

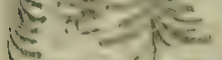

5.6.

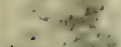

$\therefore \rightarrow+1, c^{2}$

$\because r+4$

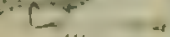


I refer to Old George Skelton and his sons, George, IVilliam, and Richard Skelton.

Finally, I give a large plan of a Decoy-pipe complete in all details. It is one that may be exactly copied in every respect wherever a pipe is desired to be made, or to whatever pool it is wished a pipe should be attached. By studying the previous instructions and dimensions, and by reference to this plan the Author hopes, and incleed feels assured, that any one wishing to do so can now, not only construct a Decoy, but succeed in the art of Decoying as well.

Description of Decoy Pipe (see opposite Plan).

Blue-Water.

Green-Turf.

Brown-Banks, $4 \mathrm{ft} .6$ in. high.

Arow's indicate the direction the wind should blow from to work the pipe; the centre arrow being the most suitable wind for the purpose.

A. Breastwall landing, 20 yards long, $7 \mathrm{ft}$. wide at its widest part.

B B B. Backwing landing, commencing at $5 \mathrm{ft}$. wide at the head hoop, $\mathrm{C}$ and gradually narrowing to $2 \mathrm{ft}$. wide opposite the last screen, where the bank that shelters its landward side terminates.

Outside the head hoop this landing is continued 25 to 30 yards in length by $7 \mathrm{ft}$. wide to where it meets the steep bank round the main pond (see plan facing page 55).

c. Head hoop, a trifle over $27 \mathrm{ft}$. from foot to foot, $5 \mathrm{ft}$. at the crown above the water, and from 46 to $47 \mathrm{ft}$. on the round (each hoop drops about $4 \mathrm{in}$. in height, till the smallest is reached, the latter being only $2 \mathrm{ft}$. high and $2 \mathrm{ft}$. in width).

D. Head show place. There is just space on the bank for the dog to run round the foot of the projecting breastwall screen, and so enable him to spring back again to $\mathrm{D}$ after jumping on to the landing $\mathrm{A}$ at $\mathrm{E}$ (the yackoop).

F F. The curved path concealed by shrubs (closely , lanted on raised earth) by which the Decoyman runs to the head show at $D$ when he has enticed the fowl under the net, the latter performane : having probably Inought him in the rear of the fourth or fifth screen from the head hoop, 
and so conveniently near the path. If the Decoyman has led the ducks a good way under the net, and as far as the fourth or fifth hoop, he does not then return all the way to $\mathrm{D}$, as it is not necessary. He, instead, turns down the short centre path $(G)$ and appears behind the birds over the dog-jump in line with the first hoop. If the Decoyman has an assistant this man waits at the seat, as from here he can see the Decoyman's signal. A wave of the arm upwards on the part of the latter and the assistant hastens to D ; a short downward motion of the Decoyman's hand and he shows instead at the dog-jump opposite the first hoop, the Decoyman having signalled thereby that the fowl are some way up the pipe, and that it is not requisite for his man to go all the way to the head show to drive them.

II I. Approaches to the pipe that lead from the path that surrounds the Decoy.

P P P. The smooth turf on which the screens (sec zigzag lines) are placed.

For directions in cutting the ditch see plan facing page 36 . For particulars of hoops, netting and construction, see pages $36,37,38,39,42$, $44,45,46$. 


\section{PLAN OF DECOY WITH 5 PIPES, SCALE-I2O FT TO AN INCH.

$100 \quad 50 \quad 000 \quad 300 \quad 300$ Feet

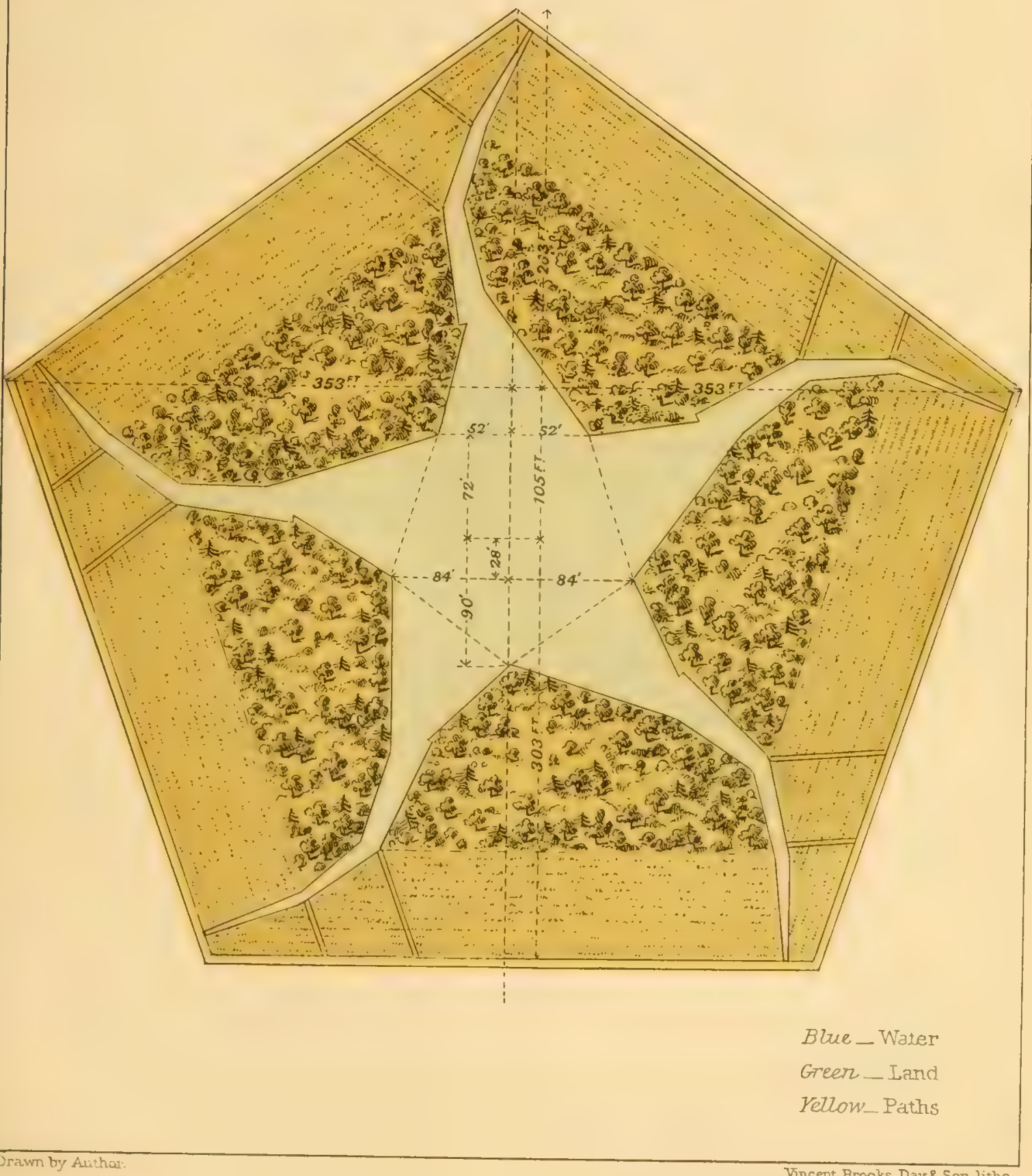





\section{A LIST OF DECOYS}

In the British Islands hereinafter described, showing the County in which each is situated. The names in italics are those of the Decoys now in use. Counties not named have no Decoys.

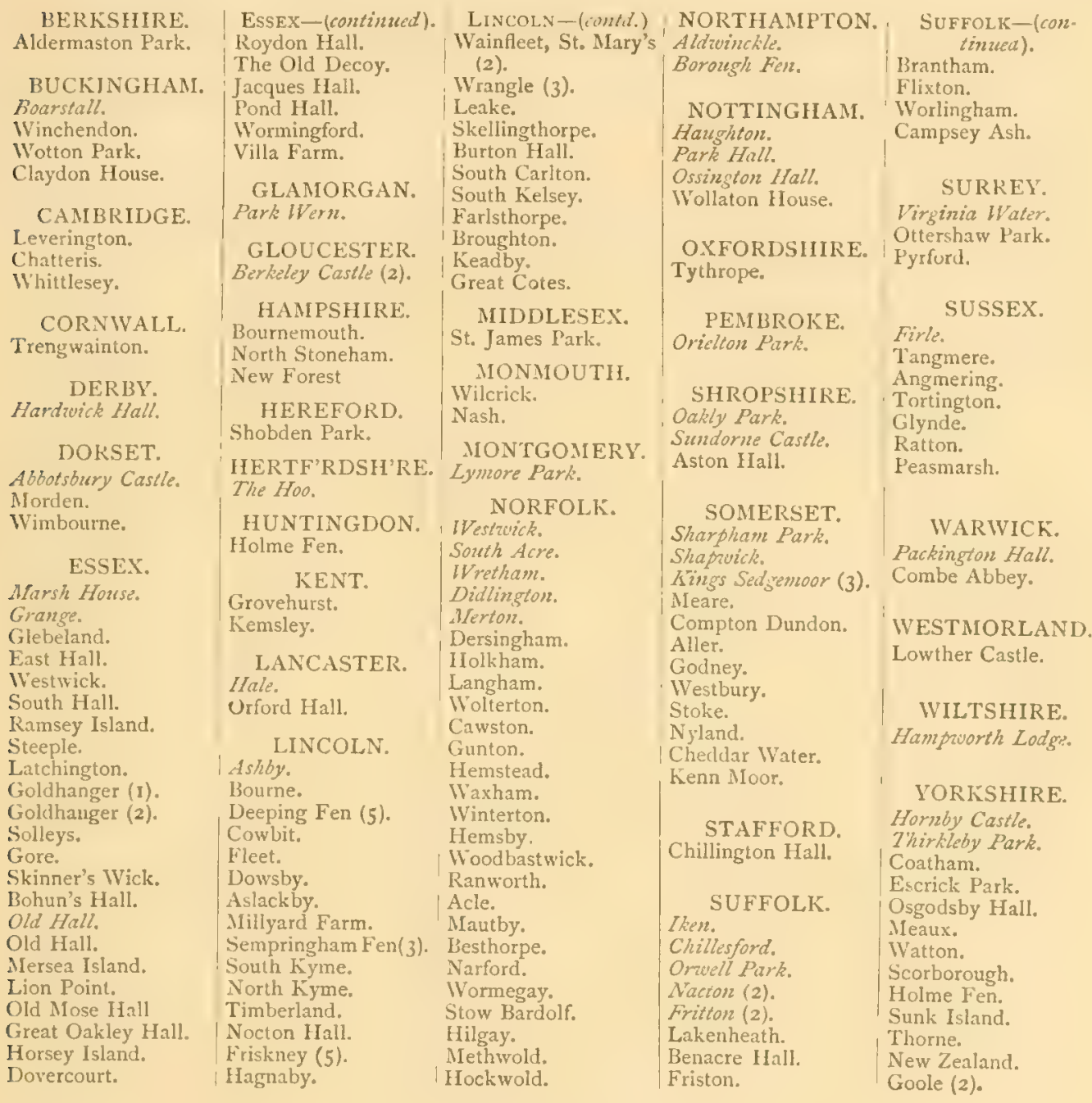

SCOTLAND.

None, past or present.

IRELAND.

\author{
CORK. \\ Longueville. \\ Doneraile Court. \\ DOWN. \\ Lough Beg. \\ GALWAY. \\ Eyre Court. \\ Clonfert.
}

KILDARE.

Ballynakill.

Lyons.
KILKENNY.
Desart Howe.
LOUTH.
Glyde Farm.
Lisrenny.

MEATI.

Lismullen.

IIountainstown.

Beaulieu.

Rathescar.

Oriel.

LIMERICK.

larteen.

Mount Lauise.

SLIGO.

Markree Castle.
TIPPERARY. Kilcooley.

TYRONE.

Caledon House.

WICKLOWV.
Anamoe.

QUEEN'S CO. 


\section{HISTORY OF DECOYS.}

CHAPTER V.

Decoys in the County of Berkshire.

\section{Decoys in use.}

None.
Decoys not in use.

Aldermaston Park.

At Aldermaston Park, io miles WSW. of Reading, the residence of Mr. Higford Burr, may be seen the remains of an old Decoy long clisused. It has not been worked within the memory of man, but numbers of ducks still resort there in hard winters, as many as from 200 to 300 being seen at one time.

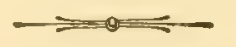

Decoys - in the County of Buckinghamshire.

This county is more frequented by wildfowl than is generally supposed. That such was also formerly the case is evinced by the fact of its having contained several Decoys, one of which, that at Boarstall, is now flourishing.

The neighbourhood of Thame is still noted for the number of Ducks and Teal that visit it during hard weather. At Otmoor, 7 miles from Thame, it is no unusual occurrence to see 1,000 acres of low land flooded, and I need scarcely say haunted by numbers of wildfowl, a large proportion of which are caught in the neighbouring Decoy of Boarstall. There are also several large lakes and reservoirs in this county on which a great many fowl congresate-notably at Shardeloes, Willesden, Stowe, Wotton, and Halton. On the latter, it has been computed that as many as 3,000 wild waterfowl have been seen on its surface at one time during recent winters. 
Decoys in use.

Boarstall.
Decoys not in use.

Winchendon.

Wotton.

Claydon.

\section{Boarstall Decoy.}

This Decoy lies a quarter of a mile north of Boarstall, in Bucks, a village of 250 inhabitants, and 8 miles NW. of Thame.

The Manor of Boarstall was formerly part of the ancient forest of Bernwode (disafforested in 1623), and is said "to have its name of one Nigrel, a forester of Bernwode, who, having killed a wild boar in the forest, had given him by the King, as a reward of his courage, a hyde of arable land called Deerhyde, on which he built a mansion, and called it 'Borestale'.... However this may be, it is said that Boarstall was given by one of the IVilliams to Nigel aforesaid, together with the rangership of the forest of Bernwode, by the livery of a horn, which is still preserved as a curious piece of honourable antiquity." (Kennett's Par. Ant. Vol. II. p. 5I8, Ed. 1815.) The chief object of interest in the village is the ancient Tower which (according to Lipscombe) Sir John de Handlo was licensed to fortify and embattle in the year 1312.

This Tower, with the adjoining house, was garrisoned in 1644 for the king and was strongly fortified; it stood several sieges.

The Manor was then the property of the Dynham family, and Lady Dynham resided there in 1650 . It passed to Sir John Aubrey, the second Baronet, jure uxor, and he died there in 1700.

The Aubreys lived at Boarstall House until Sir John Aubrey, the sixth Baronet (who died in I S26), pulled it down, leaving the Tower standing, and went to reside at Dorton House, 3 miles distant.

On the death of Sir Thomas Aubrey, the seventh Baronet, in the year I 856 , the estates passed to his niece Elizabeth Sophia, the wife of Charles Spencer Ricketts, Esq., and on her death, in the year $1 \$ 73$, to Charles Aubrey Ricketts, her son, who thereupon assumed the name of Aubrey, and is the present owner of the Boarstall, Dorton, and Brill estates, and proprietor of the Decoy.

There is no record of the age of the Decoy.

Kennett say's, "There is observable in this Lordship of Borstall a fine 
Decoy for wild ducks, a matter of great ingenuity as well as curiosity." (Vol. II. p. 5 I8, Ed. 1815.)

Lipscombe, who wrote in the year $1 \$_{3} 1$, remarks: "Within this lordship is an ancient Decoy pond of about 3 acres for Wild Duck, Teal, Wigeon, \&c., which abound in the contiguous marshes called Otmoor. The Decoy consists of several narrow channels communicating with a lake to which the wildfowl resort, and being prompted by a number of tame ducks (obedient to the signal of their keeper, who invites them with a small pipe to their food) to follow them into these channels, are prevented returning by a trap, and their escape being intercepted by nets spread over the channels, the keeper with his dogs secure the captives, of which great numbers find a ready market in the neighbouring towns; and some are sent to a distance."

The Decoy stands on the second tier of rising ground above and to the south of the low swampy tract of country, many thousand acres in extent, called "Otmoor," which was formerly part of the forest of Bernwode.

To the south of the Decoy the land gradually rises, and at a mile distant are the Brill Hills, the highest point of which (Muswell Hill) is 744 feet above the sea level. The Decoy pond itself consists of about $2 \frac{1}{2}$ acres of water with four pipes (formerly six), standing in the centre of a wood of It acres. A keeper's lodge adjoins the wood, and the Decoy is regularly worked; a dog is used and a few Decoy ducks. The yearly average of fowl taken is $\$ 00$, and the best season on record produced over 2,500 head.

The kecper, who has been eighteen years in charge of this Decoy, says that he has noticed only a few Pintails on the pond since I 879 ("at that date there were several"), and that he occasionally sees Shovellers. He reports that a few Divers are generally on the pond in February. 'The Decoyman's cottage at Boarstall is within a few paces of one of the pipes.

At Winchendon, near Aylesbury, formerly belonging to the Duke of Marlborough, but now the property of Baron Ferdinand de Rothschild, there used to be a trap Decoy, a farm there being still called "The Decoy," but it has not been worked within the memory of man.

The following notes of this Decoy have been kindly supplied to me 
by Mr. Henry Birch of Thame, to whom I am also grreatly indebted for similar notes on the Boarstall Decoy above quoted.

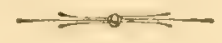

\section{Winchendon Decoy.}

The parish of Over or Upper Winchendon is situated in Bucks, 7 miles west of Aylesbury.

The Manor up to the time of the Dissolution belonged to the monastery of St. Frideswide. It then passed into the hands of the Goodwyns, who built a house there, called "Winchenden House," and subsequently the estate became the property of the Whartons. The estates of the last marquis were forfeited, and the Winchendon Estate was purchased by the second Duke of Marlborough, who in $1 ; 60$ pulled down the house (save part of one wing, which is now occupied as a farm-house, and which, togrether with the walled garden, is called "The Wilderness," a name which originally belonged to a grove adjoining the ancient mansion). The wood called "The Decoy" lies in the valley, about one mile from the site of the house.

The pond in the centre is dry, but is very clearly defined, and covers about 2 acres of ground, whilst the wood surrounding it measures 5 acres, and is octagonal. There are three distinct pipes; the principal one runs from the south corner, whilst there are others equally well preserved, but apparently shorter and narrower, to the east and west. Towards the north there are signs of another channel, but as the ground falls away on that side it is improbable that it was more than a drain.

The ground rises considerably to the south and east, and the Decoy was evidently supplied with water from a spring on the hills to the southeast; indeed there would be no difficulty in filling it at any time.

The estate was purchased from the Marlborough family in i $S_{72}$ by the Rothschilds.

The present tenant, Mr. Cooper, came to the farm thirty years ago when he was a boy. One of the wooden traps which was made to hold the Decoy ducks and to entrap the others was then in existence, and was given him to play with, and was turned by him into a rabbit-hutch. At 
that time the Decoy keeper's house was standing within the wood; it was pulled down ten years ago.

John Capel, a man of eighty, a native of and still living in Winchendon, remembers the Decoy all his life, but never remembers its being worked; incleed it appears to have been dry ever since he knew it. He remembers "the trap," and gave it to Cooper, for whose father he was then working. John Capel, when a young man lived for some years in the house in the wood. He states that his father, who was also a native of Winchendon, remembered the Decoy being worked, and that the ducks went to the Duke.

The valley in which the wood is situated extends from Winchendon to Dorton, and Wotton (the seat of the Duke of Buckingham), and is about 3 miles from Boarstall. It is well watered, and in former days no doubt wildfowl were plentiful.

At Wotton Park, 7 miles N. of Thame, on the estate of the Duke of Buckingham and Chandos, are three small Decoys, each with three pipes, and connected with a lake covering about 56 acres of water, and when in working order were used to supply the wants of the family, whether at IVotton or Stowe. They were worked until i 875 , when the present Duke went to India, at which time the pipes being out of order were not repaired. They are now, as I am informed by his Grace, about to be renewed. The take was principally in December and January, but in some seasons a few were caught during the period of the equinoctial gales, and occasionally some in November.

From 1820 to 1840 the average take annually was about 310 , the largest capture having occurred in 1837 , when 381 Ducks, 16 swans, and 2 Wild Geese were taken. From ${ } S_{30}$ to $18_{42}$ i6 Wild Geese were taken in these pools. Between 1846 and 1873 , less wildfowl being required for the use of the household, the annual take averaged only 86.

Half a dozen Dutch call-ducks and from twelve to twenty domesticated and trained wild ducks were kept as Decoys, and no dogs were used.

At Claydon House, 3 miles IVSW. of Winslow, the seat of Sir Harry Verney, Bart., is the site of an old Decoy, now drained, and nearly as dry as the surrounding land. No one living can remember the Decoy being 
worked, although one old man in the neighhourhood can recollect its existence seventy ycars ago, when some Decoy ducks were kept there, and a good many wild ones used to frequent the pool in winter.

The Decoy had four pipes, and was a square pond with a small rivulet running through it.

\section{Decoys in the County of Cambidge.}

This county, like its neighbour Huntingdonshire, possessed in its northern part a large area of fenlands, consisting of 200,000 acres, or nearly half of the Great Bedford Level.

The principal Fens were Morris Fen, St. Giles' Fon, and Thomey' Fin, north of the River Nen: Laddus Fin, Cranmore Fon, Thute Fen, IFimblington Fen, Block Fin, and Sutton Fen, south of the River Nen, and between it and the Bedford River or Cut. South of the latter were Downham. A shwell, Middle, Blunt, North, and Sedge Fens, all of which lay round the town of Ely, and adjacent to the rivers Ouse and Cam.

Though Cambridgeshire contained no meres like Norfolk or Huntingdon, still it was and is a network of water channels, that cover its surface from Cambridge and Newmarket to Peterhorough and Wisbeach,and, like other counties containing parts of the Great Bedford Level, it was frequented by hosts of wildfowl in days gone by.

It was not, however, a favourable county for Decoys in its Fen districts, for, like Huntingclon, these were liahle to frequent floods, and were destitute of trees and underwood.

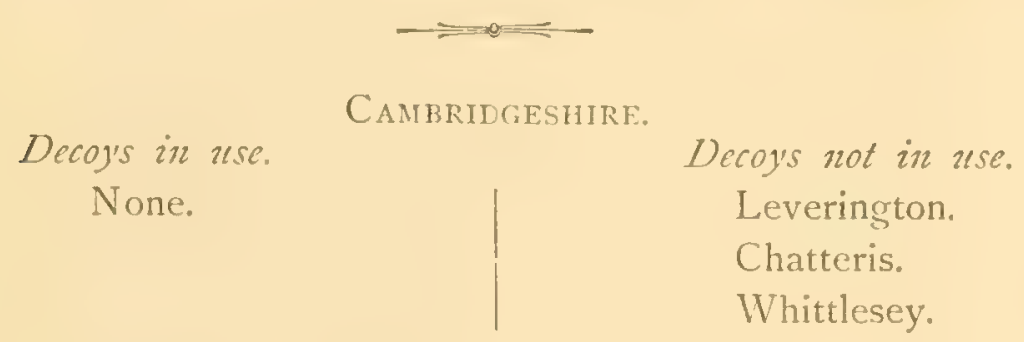

Leverington Decor:

Two miles NIV. of Wisbeach. A map of 1760 shows a Decoy as then existing in the parish of Leverington. There is still a farm that goes by 
the name of the "Decoy Farm." The site of the Decoy itself has been ploughed up, though its general outline may still be traced. In one of the rooms of the Decoy farm house there are several panels that were moved from the old Decoy house when it was pulled down. These are very interesting, as they indicate the shape of and the method of working the Decoy: The father of the present tenant of the Decoy Farm, who was born in 1772 , knew the last man who worked the Decoy, so that it has probably not been in use for 100 years. The last owner of this old Decoy was a Mr. Nares, and he is reported to have been so successful, as to have purchased a farm out of the profits of working it.

The present owner of the land is the Rev. F. Jackson, of Parson Drove Vicarage, Wisbeach.

\section{Chatteris Decoy.}

Four miles SE of Chatteris and $3:$ miles NE. of Somersham in North Fen.

Watson, in his History of Wisbeach, as also Wells in his History of the Fens, mentions a Decoy here of which no trace now remains. The land, however, is still called "Decoy Ground," and on an old parish map I find it alluded to as follows :-

"Site of Decoy erected by Colonel Valentine Warton destroyed by the populace at the restoration."

\section{Whittlesey Decoy.}

One-and-a-half miles NE. of the village of Whittlesey and long disused.

\section{The Bedfori Level.}

As this county contains so large a proportion of the celebrated "Bedford Level," it may be as well to give here a brief description of a district so unique, as also of the process by which it has been gradually converted from a watery waste to its present state of fertility.

A glance at the map shows the great "level" of the Fens comprised an area of 1,306 square miles, and formed part of the counties of Lincoln, Northampton, Huntingdon, Cambridge, Suffolk, and Norfolk, and extended 
in an almost unbroken surface from the shores of the Wash to the high lands which form its extreme borders. A difference of a few feet in the level of this vast extent of country would cause the waters of the ocean once more to cover the whole tract. That this extensive "level" in bygone ages formed part of the bed of the Wash, from which it was raised by a gradual process of silting, its geological structure plainly shows, and the same process is still adding largely to the dry land along the sea-shore. But that this process has been frequently interrupted the presence of buried forests imbedded in the peat also clearly shows.

All this, of course, was prehistoric, but we can easily imagine that before any attempt at artificial drainage altered the face of the country, the whole plain would present the appearance of one great sedge-covered tract, intersected with sheets of open water, vastly more extensive in winter, and studded here and there with drier spots or hills, densely covered with thickets of alder and willow, with perhaps occasional spots, more elevated still, bearing a growth of timber trees.

In addition to the influx of water from the sea, this low-lying tract was subject to constant flooding from the up-country which surrounded it, and probably one of the first difficulties experienced in attempting any system of drainage was, as now, the solution of the problem how to dispose of these inland waters. The first attempts at drainage attributed to the Romans appear to have been restricted to shutting out the waters of the ocean by means of sea-walls, but it must soon have been discovered that much more than this was required, and attention was doubtless directed to restraining the rivers within due bounds, and here the dead level of the country would form the chief obstacle. However, gradual success at length rewarded unceasing labour, and although the Isle of Ely was still a veritable island that could only be reached by boats or over the ice in winter, and much of the country could only be travelled on stilts, some progress was made. From the early records of the efforts made to reclaim portions of the Fens some curious glimpses of the country and its inhabitants in Saxon times are afforded, and later, the records of disasters, and the remedies applied, show the fragmentary nature of the attempts to conquer the too abundant waters.

At length works on a large scale for the better drainage of this immense extent of waste were undertaken by Morton Bishop of Ely, in the reign of 
Henry VII. Next a General Drainage Act was passed by the advice of Lord Burleigh in $160 \mathrm{I}$, but it was not carried out till the reign of James I., who, in $162 \mathrm{I}$, brought over the famous engineer Vermuyden from Holland to assist in the matter. After completing several extensive drainage works in North Lircolnshire, at the Isle of Axholme, and close by in Yorkshire, at Hatfield Chase, near which place he died in poverty, Vermuyden undertook to drain the Great Level in 1629, on consideration of his being granted 95,000 acres of the reclaimed land. He was at first hindered in his contract by the popular prejudice, at that time existing, against a foreigner; but eventually, being aided by the Earl of Bedford, from whom the Level derives its name, and who died in 1641 , Vermuyden at length declared his great work completed in 1638 .

However, in 1639 the whole proceedings of the engineers and projectors of the recent drainage were annulled, the drainage was declared defective, and the land promised as compensation for the trouble and expense of the undertaking to Vermuyden and his associates, the Earl of Bedford and Bolingbroke, was forfeited before it was enjoyed.

Charles I. now proposed to undertake the whole concern, and a new commission was formed.

But in consequence of national troubles no attempt was made to carry out the works, and meanwhile the former ones went rapidly to decay, and so remained till 1649, when a new Act was passed and the whole management of the affair was committed to the care of William Earl of Bedford, the son of Francis, who, with Vermuyden, was the original undertaker of the scheme, and the entire work was considered as finished in 1652. Since which date the various levels, or parts of the Great Level, have been improved and drained still more effectually. Rennie being employed in I 807, Telford in 1822, and Mr. Hawkshaw in I 862.

Previous to 1807 much of the pristine wildness of this tract was existant, especially in Lincolnshire.

The country the Great Level was formed of being so flat and the rivers consequently so slugsish, these latter were often unable to carry off the floods even after the Level was supposed to be drained; hence it was frequently flooded till comparatively recent times (1SO7). Numerous broad tracts of many square miles of water and marsh were, previous to that date, to be seen in the counties that form the Great Level, diversified 
here and there with a little patch of corn or pasture, but for the most part consisting of wild and well-nigh pathless morass.

The original drainage scheme that was completed in 1652 by William Earl of Bedford must not be imagined to have caused the formation of firm ground, such as is now to be seen in the Fens. The cuts, dykes, banks and sluices and other contrivances then made may be said merely to have turned what was in winter an inland sea into a vast marsh, in the hollows of which such meres as Whittlesey and Ramsey were formed by the surplus waters that could not reach the sea.

The Fens, especially those of East Lincoln, were not finally drained or really cultivated until the close of the last century : and up to as late as I 822 immense extents of wild Fen and marsh still existed here and there all over the Bedford Level. Whittlesey and Ramsey meres and their immediate Fens not being drained till thirty years later.

And still the old Fens, of which the Great Level is formed, require careful supervision. For as they are dried, improved, and drained, so they gradually fall below the level of the sea and rivers, and the destruction of a sea-wall by a high tide and onshore gale, or the flooding of a river, are liable to lay (as occurred in I 862) many thousand acres under water in the course of a few hours.

There are even now engincers who look upon it as no impossibility, by an unlucky combination of wind and tide, for the "Great Bedford Level" to be again flooded as of yore, and who point to similar catastrophes in Holland as a warning for watchfulness.

In these days the so-called Fens are but great flats of level grain fields or meadows, divided by ditches instead of by walls or hedges. They are intersected by numerous perfectly straight canals that run like silver threads into distant space, and into these the ditches and minor drains are led.

It is probable that all the eastern county Decoys were constructed after the first great drainage of the Fens was completed in 1652 , when it was seen what numberless wildfowl, as was but natural, resorted from all parts to the marshes and ooze left by the out-driven floods.

Previous to this the ducks were habitually driven into nets, as previously described. A practice continued till much later times on such meres as were formed here and there by the receding waters.

The Bedford Level, consisting of 400,000 acres, is divided into the 
Middle, South, and North Level. The greater part of the Middle Level and much of the South Level are in Cambridgeshire, including the whole of the Isle of Ely.

\author{
Decoys in the County of Cornivall. \\ Decoys in use. \\ Decoy's not in use. \\ None. \\ Trengwainton.
}

At Trengaidinton, in the parish of Madron, near Penzance, now the seat of Mr. T. S. Bolitho, may be seen the remains of an old Decoy which was constructed by Sir Rose Price, the former owner of the estate, about I8I9-20. Although large numbers of wildfowl at that date frequented the valley, and a good many used to be shot at three different pools, the attempt to decoy them was not successful, and the Decoy was abandoned before Sir Rose Price's death in 1835 .

This was not a properly constructed Decoy, or else it would have succeeded well, considering the favourable position in which it was placed.

It was intended for a trap Decoy, and had no Decoy pipes as usually made.

The pond was 60 yards square. At each corner was a small, short pipe leading to a net-covered enclosure of a ferv feet square. The entrances to the pipes had falling nets to shut the fowl inside the enclosures - should they enter them. In each enclosure was placed a sunken slab of stone on which grain was placed to attract the fowl from out of the pond.

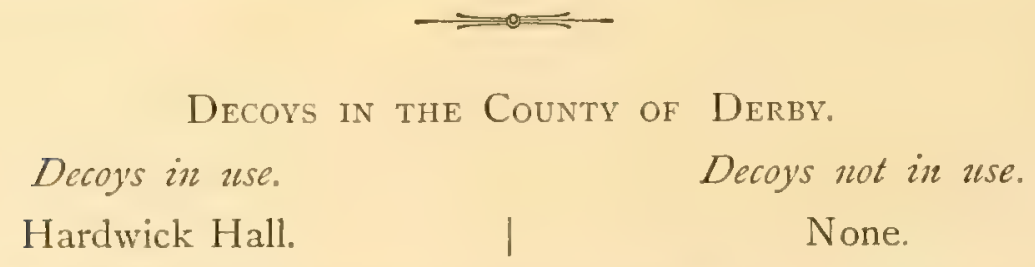

Hardwick Hall, the seat of Lord Hartington, 5 miles SE. of Chester field, near North Wingfield.

A very perfect trap Decoy exists here, similar to those in use at Haughton, Ossington Hall, and Park Hall, in Nottinghamshire. There are two trap doors, one at each end of the cage, and this is necessary on 


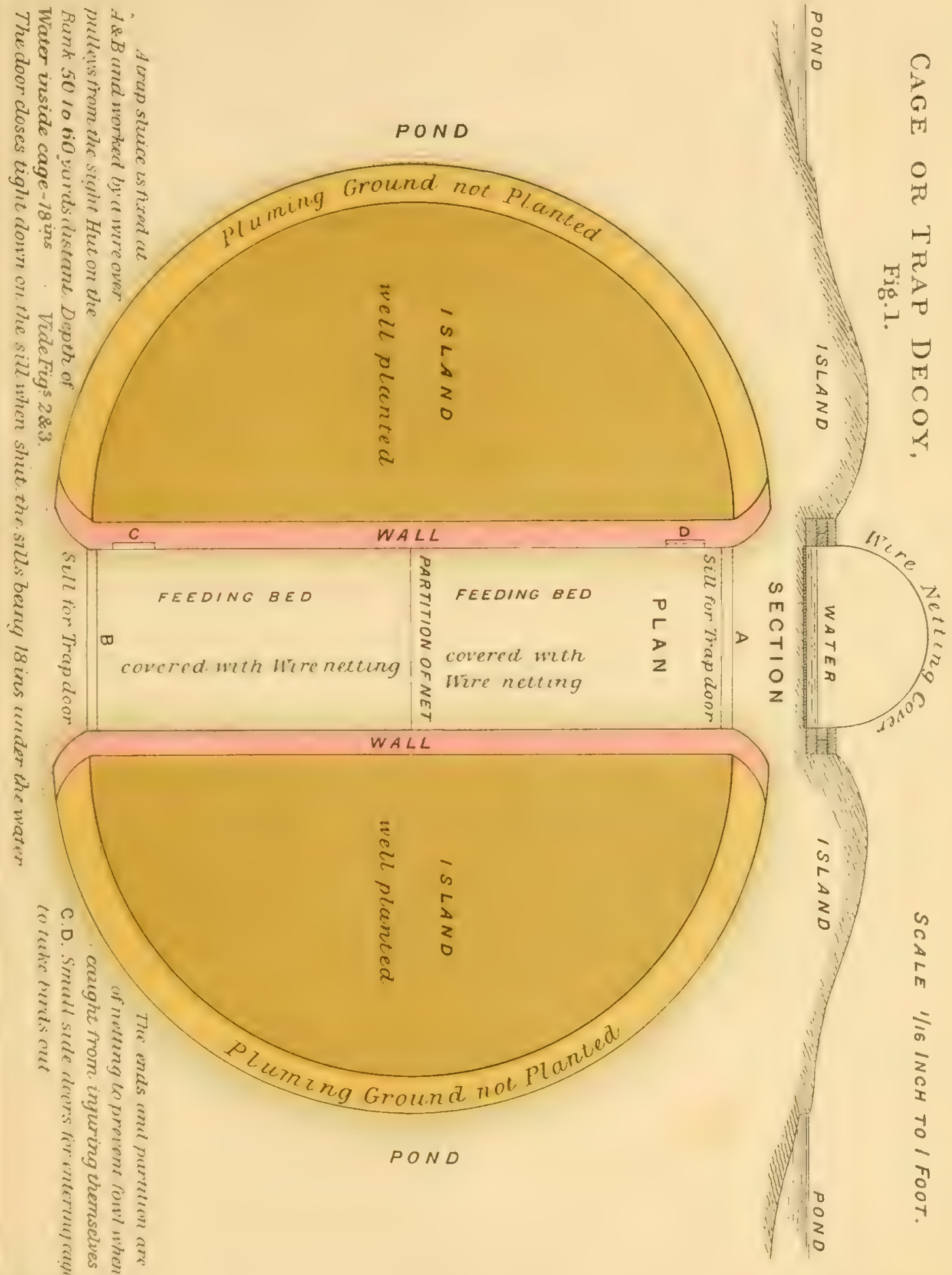



account of the ducks changing their position according to the wind. Either end can then be worked by means of two wires with separate windlasses from one "sight-house," as the cage being of wire netting the ducks can be easily seen through the partition in its centre.

The Decoy birds are always fed inside the cages, and plenty of food is strewn therein at all times to tempt the wild birds to enter.

Both trap doors are left up, and as soon as the Decoyman observes any wild birds in either partition, he slowly, and inch by inch, lowers the door that closes it, and so entraps the birds therein.

He leaves them undisturbed on the chance of making another catch in the other partition, and does not take the captives out till after "flighting" time. (See plans opposite and on next page.)

Decovs in the County of Dorset.
Decoys in zuse.
Abbotsbury.

At Abbotsbury' Castle, the residence of the Earl of Ilchester, 8 miles SIV. of Dorchester, at the head of the Fleet estuary, between St. Catherine's Chapel and the seashore, is an ancient Decoy with four pipes. The date of its construction is not known to the owner, but it is on land that formerly belonged to the Abbots of the Monastery of St. Peter, and is, therefore, said to have existed before the dissolution. Great numbers of wildfowlDuck, Teal, Wigeon, Tufted Duck, Pochard, and Golden-eye-visit it, but in consequence of there being a grood deal of open water outside the I)ecoy; and shooting carried on during the season, no very large captures are made. About ten or twelve at a time, and a couple of hundred in the course of the winter, is the average take. Close to this Decoy in the West Fleet is the well-known Swannery, consisting of several hundred birds.

In Hutchins" "History of Dorset," allusion is made to the Decoy and swannery at Abbotsbury as follows (Vol. II. p. 273, 3rd edition) :-

"About a quarter mile SIV. from Abbotsbury is a large Decoy, where great plenty of Wildfowl resort and are taken. 
CACE DECOY.

Fis.:2.
SICHT HOUSE

in bark opposite trap 50 to 60 yands distant
Rouf of Trap
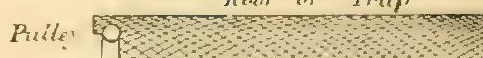

llater Level

6.6
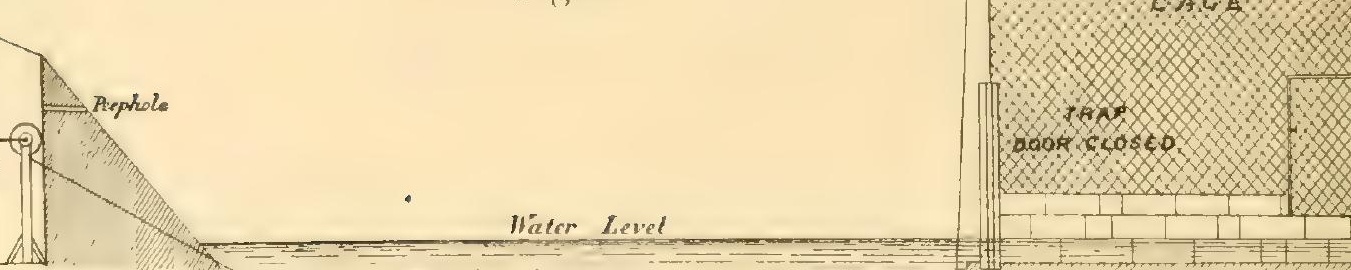

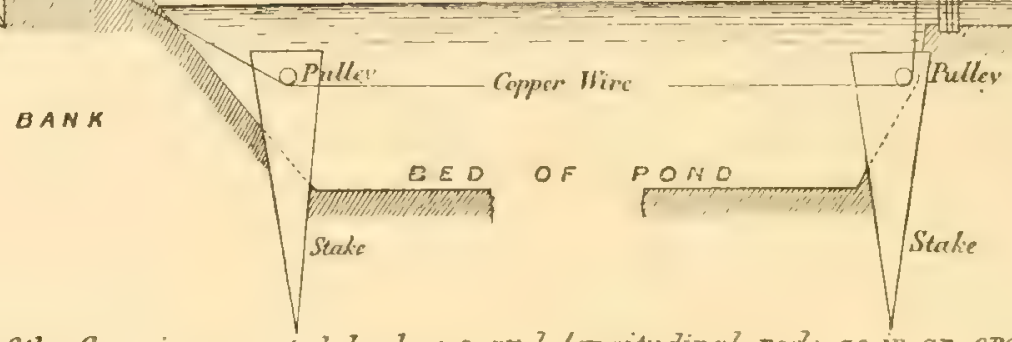

NB. The netting of the Cagc is supported by hoops and lemgitudinal rouls, as in an ordinary

Decoy Pipe

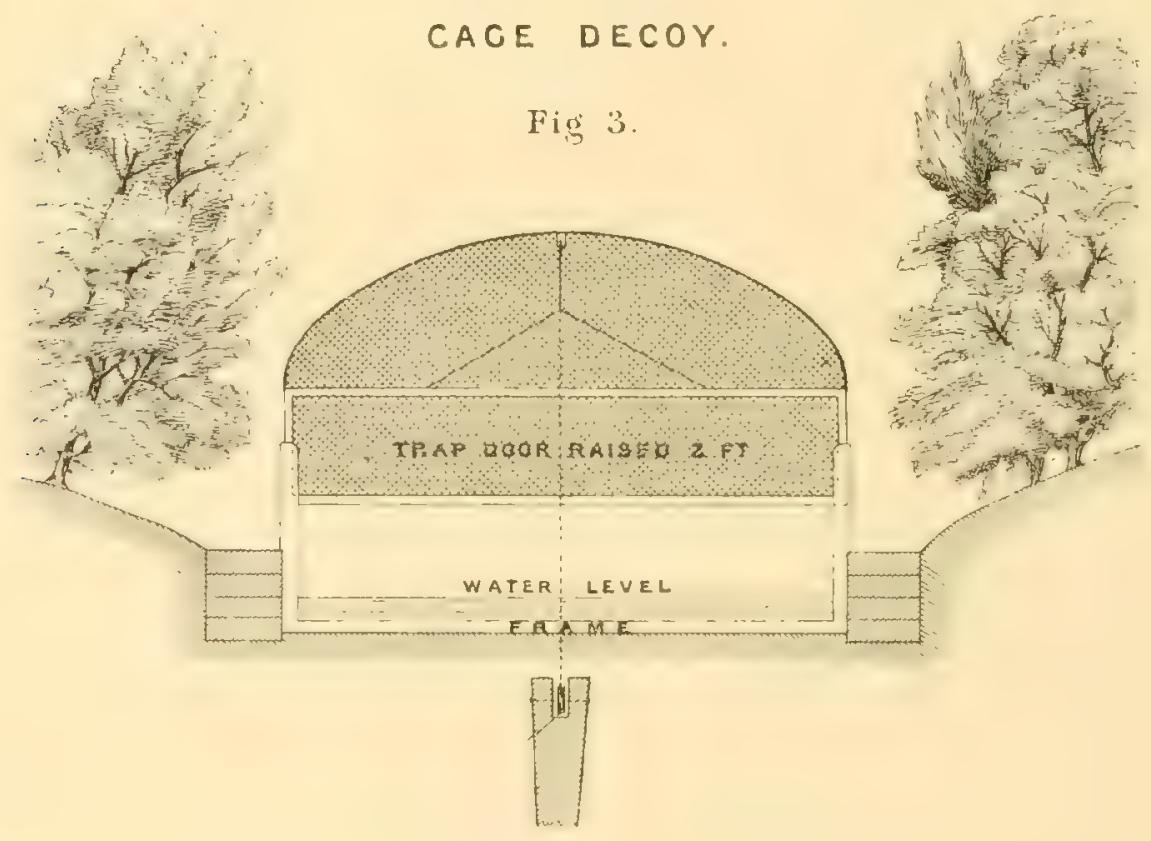


"South of the village is a noble swannery. . .

"It is the head of the Fleet Estuary, a long lagoon running 8 miles up behind the Chesel Beach from Portland mouth to Reeds End boat-house on the beach near Abbotsbury. . . .

"In the open or broad part of the Fleet are kept 600 or 700 Swans,

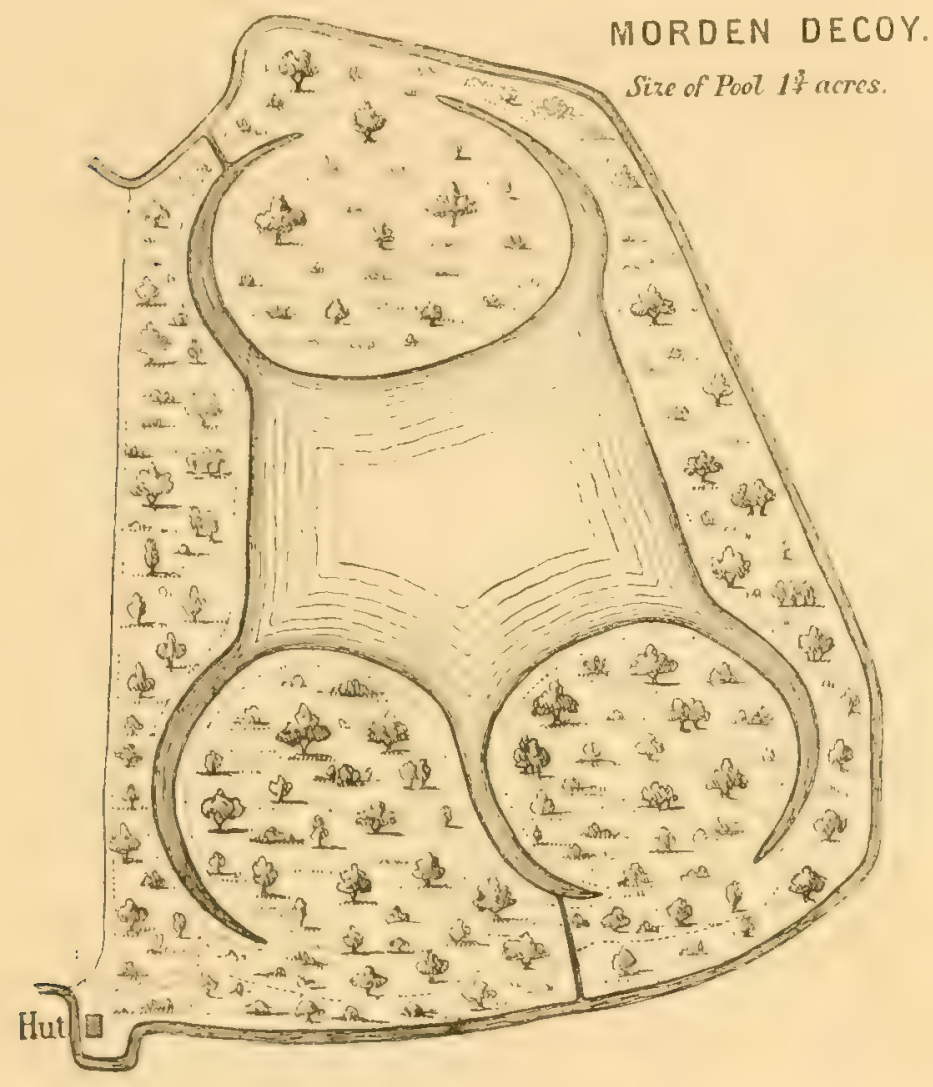

formerly 1,500. 'The Royalty anciently belonged to the Abbot, since to the family of Strangways, now to the Earl of Ilchester."

The revisers of the 3 rd edition remark that at that date ( 1867$)$ there existed ; oo Swans on the Fleet. A great many still frequent this water.

Morden, 6 miles $N$. of Wareham, on the property of Miss I)rax of Charborough Park. There used to be a Decoy here until 1856 , when it ceased to be worked, and since then the shooting around it having been 
let, the place has been too much disturbed to admit of the Decoy being successfully carried on.

The Morden Decoy was a famous one in its day, being admirably placed to attract wildfowl from the Poole Harbour Estuary, a large extent of water and ooze, with numerous creeks, nearly 6 miles square.

The Rev. T. Pearce, well known as a sporting writer under the name of "Idstone," and who formerly rented this Decoy, tells the Author it has cleared as much as $£ 300$ in a season, which would represent fully 7,000 to 8,000 fowl, taking expenses, and bircls such as Teal and Wigeon, into account.

The Decoy is situated in a swampy valley, surrounded by heath. The enclosure is 4 acres, with an open pond of $I \frac{3}{4}$ acres. It has five pipes, as shown on plan, somewhat curiously planned. The Decoy enclosure is planted with bos myrtle, alder and willow, with some oak and birch.

This Decoy could easily be put in working order again, and, from its position near the coast, should still do well. Charborough Park, near which this Decoy is situated, has always been held famous for the wild beauty of its surroundings, as well as for the number and variety of the grame and Wildfowl that frequented it and its vicinity, equalling if not even surpassing Lord Malmesbury's estate at Heron Court, so famous in this respect.

Wimboume.-A Decoy was commenced near here by the late $\mathrm{Mr}$. Coventry, of the Knoll, Wimbourne, but it was never completed. 


\section{HISTORY OF DECOYS-(contimed.)}

\section{CHAPTER VI.}

\section{Decoys in the County of Essex.}

Thoucin this county never possessed any fens or meres, like Norfolk, Suffolk, Lincoln, Cambridge, Huntingdon or Northampton, still, owing to its extensive sea-coast and numerous tidal estuaries, it contains many disused Decoys. Essex, indeed, rivals Lincoln and Norfolk in this respect. As may be expected, the Essex Decoys were chiefly placed near the banks of the great estuary of the River Blackwater.

This sheet of water is some dozen miles in length and two miles in width,--with its shores, and outside its mouth, tlanked for miles at low water with fine feeding-grounds, in the shape of beds of ooze to attract and support wildfowl. Round the estuary of the Blackwater at least fourteen or more flourishing Decoys existed. To the north of the Blackwater, the Hamford Water estuary, with its multitudinous creeks, small islands, and channels had, as might be expected, attendant Decoys. Still further north, on the border of the county, and dividing it from Suffolk, is the estuary of the Stour, with also some Decoys on its banks, a sheet of water but one-third less in size than that of the Blackwater. In the southern part of Essex, between the Blackwater and the mouth of the Thames, the estuary of the River Crouch, with its many arms and backwaters, afforded protection and foud to the wildfowl that frequented the coast of Essex and its mud-flats. The fow taken in the Essex Decoys were, and indeed are, chiefly Wigcon, as they are lured to their capture from the sea-coast,-whereon these birds always predominate among the Duck tribe. For this reason there are no Decoys in Essex distant from the sea, as is the case in several of our other eastern counties wherein large meres and fens existed to attract wildfowl, and in which Duck, Mallard, and Teal were abundant, and therefore usually taken in the Decoys. 
Decoys in use.

Marsh House.

Grange.

Old Hall.

Decoys out of use.

Glebeland Decoy.

East Hall.

West Wick.

South Hall.

Ramsey Island.

Steeple.

Latchington.

Goldhanger (I).

Goldhanger (2).

Solleys.

Gore.

Skinner's Wick.

Bohun's Hall.
Old Hall (Teal Pond).

Mersea Island.

Lion Point.

Old Mose Hall.

Great Oakley Hall.

Horsey Island.

Dovercourt.

Roydon Hall.

The Old Decoy.

Jacques Hall.

Pond Hall.

Wormingford.

Villa Farm.

The Marsh House Decoy is in Bradwell Marsh, south of the Blackwater. This Decoy is situated on property belonging to the Dean and Chapter of St. Paul's, and is in the occupation of Mr. Robert Page of Bradwell. The pool is rather more than an acre in extent, and, like that in the adjoining marsh at Tillingham, has six pipes, and both pools closely resemble the Friskney Decoy (page 1 22). In a map of Essex of 1825 , prepared from a survey made in $1 \$ 24$, three Decoys are shown on the coast south of the Blackwater. The northernmost of the three, known as the Glebeland Decoy, Bradwell-juxta-Mare, has been disused for more than sixty years; the southernmost is that still worked in Tillingham Marsh by Mr. C. Page, and the centre one is that now under consideration. It lies $\frac{3}{4}$ of a mile due west from the coast, and $I_{\frac{3}{4}}$ miles E. of Tillingham, and at a distance looks like a clump of trees upon the marsh. It is not a large pool, but is very secluded and well concealed by reeds and brushwood. It has six pipes, the hoops of which are of wood.

At times a good many Wigeon are taken here, although in some years these birds almost entirely desert this Decoy in favour of that 
at Tillingham in the adjoining marsh. Mr. Page states that Pochards used often to come to his Decoy, but are not liked, as they are very troublesome to catch, diving hack in the pipe, and even flying past the Decoyman on his showing himself, instead of going into the tunnel net like other fowl. He prefers to keep them away.

One morning, when there were a srreat many Pochards in the Decoy, he had a "battue," and shot more than 70. Before the end of the week he had killed over 200 of these ducks. After this, as might be expected, they did not come so often. Mr. Page states that of every Ioo Wigeon taken in his Decoy, 30 are caught in January, 20 in December, 19 in February, 19 in November, 7 in October, 4 in Narch, and 1 in September, this being the average of ten seasons. During the same time he had the greatest number in the Decoy in January, the next most productive months being February, December, November, October, March and September, in the order named. In one year he had four Wigeon in the Decoy in August; in other seasons none have arrived until October.

This is one of the oldest Decoys now existing in the county of Essex, the land on which it stands having been reclaimed some 200 years ago, at which time the Decoy was doubtless constructed.

Mr. R. Page became tenant of the Decoy in 1865 , since which time he has regularly worked it. The average yearly catch from is59-60 to I $\$(1)+5$ was about 3.500 : since that date, when Mr. R. Pagre becance the tenant, it has been 2,500 fowl a year, and within the last few seasons the take has fallen to as low as 2,000 a year, so that the I)ecoy does not now do more than pay its expenses. The large majority of birds taken by: Mr. Page are Wigeon

Some of the previous owners of the Decoy to Mr. R. Page, who, as above stated, commenced his tenancy in 1865 , were-

I $822 . M r$. Hudson.

1837-5 I. Mr. John Willes.

I 85 I-65. Mr. Cracknell.

Mr. Hudson's son, MIr. G. J. Hudson, tells me that his father once made E400 in a year by selling the fowl he caught in this Decoy, which, taking 
into consideration deductions for Decoyman and half-birds, would represent fully io,000 fowl.

The Grange Decoy, in Tillingham Marsh, south of the Blackwater, on land belonging to the Rev. H. Jones, and now in the occupation of Mr. Charles Page of Grange Farm, Dengie, is 2 miles SE. of Tillingham, and $\frac{3}{4}$ of a mile from the sea-shore. The pool is rather more than an acre in extent, and has six pipes. The average take is from 1,500 to 2,000 fowl, chiefly Wigeon. This Decoy, like its neighbour at "Marsh House," is situated on the flats, near the coast ; these flats consist of broad reclaimed meadows, intersected by ditches, and protected from inroads of the tide by a sea-wall, and extend from near the mouth of the Blackwater estuary to that of the Crouch. The present tenant of the Decoy has held it for thirty years, and is a brother of the lessee of the Marsh House Decoy.

Both this Decoy and the adjoining one at Marsh House change about very curiously in regard to the way in which the Wigeon frequent them. For several seasons the one pool will keep the lead of IVigeon, and then the other has its turn. Or these birds will desert one pool for the other for no apparent reason.

The only other Decoy in use in Essex is the "Old Hall," which, as it is on the north bank of the Blackwater, is described later on, at page 86.

Glebeland Decoy', S. of the Blackwater, I $\frac{1}{4}$ miles SSE. of Bradgatejuxta-Mare, has been disused for more than sixty years. Its position is not far from the Marsh House, and in the same parish,- but a mile further north, near Sandbeach outfall, and $\frac{3}{4}$ of a mile from the sea.

It is to this Decoy that Daniel refers in his 'Rural Sports' (vol. iii. p. 266), where he states that "in I 799, I0,000 head of Wigeon, Teal, and Wild Duck were caught in a Decoy of the Rev. Bate Dudley's, in Essex." An old Rate Book in the Vestry at Tillingham gives the names of successive owners of the Decoy, as follows :-

I 795. Mr. Mascall.

I 797. The Rev. H. B. Dudley.

1805. Mr. Alston.

I 8 I I. Mr. Kebbell.

I 8 I 5. Mr. R. Willes, -

The last tenant before it was given up in 1822 . 
East Hall Decoy' and Wist Wick Decoy', south of the Blackwater, near Bradwell, have been disused for many years, but have been worked in present memory.

They were both in the parish of Bradwell-juxta-Mare, not far from the Decoy at Marsh House. Mr. R. Page, who works the latter, informs me that their positions are still to be discerned. The former was placed it of a mile NIV. of Bradwell, and the latter the same distance NNE.

South Hall Decoy, S. of the IBlackwater, in the parish of Paglesham, and $\frac{1}{2}$ a mile from South Hall, is in the occupation of Mr. James Wiseman. It has been disused for roo years; it is now cared for, though not worked, but there is some chance of the Decoy being put into repair by its owner. It is placed on the $N$. bank of an arm of the River Roach, and is a mile SW. of Paglesham.

Mr. Wiseman informs me that the Decoy has the remains of six pipes running ESE., SE., S., SIT., NIT., and $N$., and is an acre in extent.

Ramsey' Island, on the south shore of the Blackwater River. In an old map of Essex, published in I772, a Decoy marked "Old Decoy" is placed just south of the channel which forms the southern boundary of Ramsey Island, in the parish of St. Lawrence, and close to a farm called "Stansgate Wick."

No notes or any traces of this Decoy are now obtainable.

Stecple Decoy, in Canney Marsh, on the south side of the Blackwater, and close to the river, on the E. bank of Steeple Creek, half-way between Steeple Church and the River Blackwater.

In connection with this Decoy $I$ append some most interesting details written by my friend Mr. J. E. Harting. They are so valuable that they could not possibly be omitted from a work on Decoys.

"Stecple Decoy, in Canney Marsh.-Tradition only points to the place where, in what is to this day known as the Decoy Marsh, one hunctred and sixty years agro, a profitable business was carried on in the capture of wildfowl, chiefly Wigeon, for the London market. Fortunately, however, for those who, at the present day, take an interest in such matters, the Essex yeoman who constructed this Decoy, being a business-like man, took the trouble to write down the cost of its construction, and for thirtecen years kept a strict account of the numbers of wilefowl captured hy him 
and of the prices which they realized. This curious MS., which is contained in a small folio rolume bound in vellum, was written between the years 1713 and $172 \%$, and by the favour of the present owner, Mr. Robert Smith, of Maldon, can now be criticized. The Decoy was originally constructed in I $7 \mathrm{I} 3$, but in $172 \mathrm{I}$ the owner, evidently finding it to be a source of considerable profit, went to some expense in enlarging it; and it would appear that when the pond was dug out, it was at first filled by pumping from Steeple Creek, but was subsequently supplied from a well which was sunk at what now-a-days appears an insignificant outlay, $f \mathrm{ro}$, but which probably represents about $£ 50$ of our money.

As affording a good illustration of the prices paid for materials and labour in the days of Queen Anne, the first page of this MS. is not without interest, and I here transcribe it verbatim et literatim :-

\section{An Acct, of the Charge of Makerng the Duckoy Pond uppon} Canney Marsh by me Join Cooch I 13 .

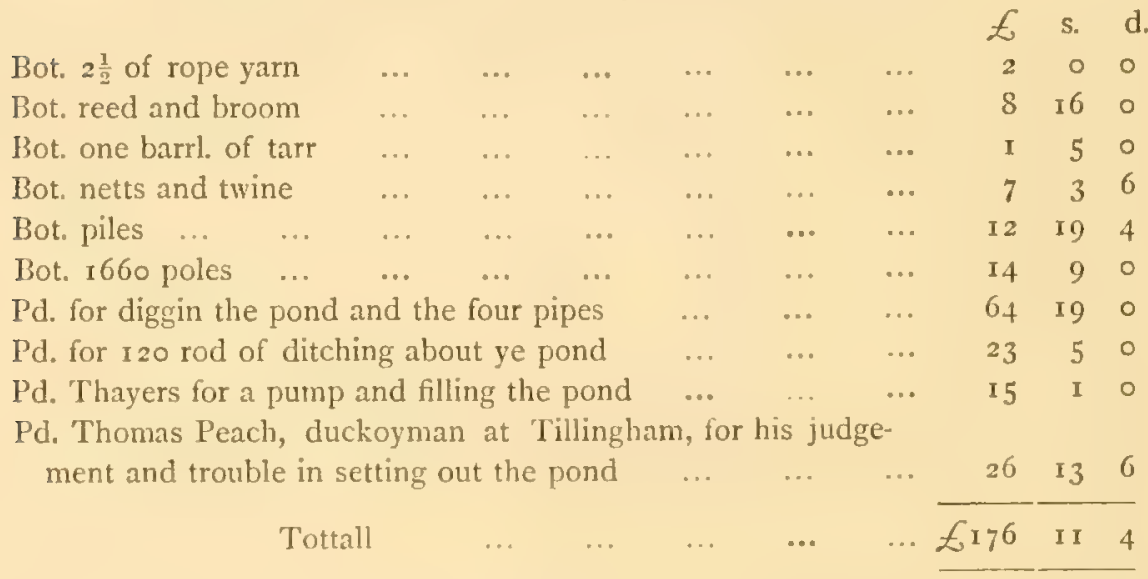

An Acct, of the Charge of Makeing the Duckoy Pond uppon Canney Marsir Larger by me Willian Cooch $172 \mathrm{I}$.

Pd. for removing pt. of a bank and diging ye new pt of ye pd.

Pd. for makeing 3 new pipes

I'd. for 600 of poles

Pd. for 300 of piles

Pd. for tar ...

\begin{tabular}{rrrr}
$\ldots$ & 97 & 0 & 0 \\
$\ldots$ & 4 & I2 & 0 \\
$\ldots$ & 4 & 15 & 0 \\
$\ldots$ & 4 & 0 & 0 \\
$\ldots$ & I & 5 & 0 \\
\hline & EIII & I 2 & 0
\end{tabular}




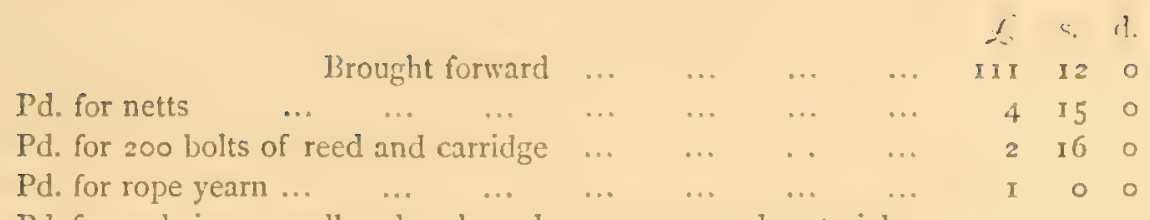

Pd. for makeing ye well and arch, and new pump, and materials for ye mill

$$
\begin{aligned}
& \text { I } 72 \text { I Totall } \\
& \text { I } 7 \text { I } 3 \text { Totall }
\end{aligned}
$$

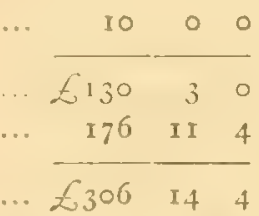

The Decoy was completed and ready for use by September, i 74 ; and on the $3 \mathrm{rd}$ of that month the result of the first day's take by "Jos. Woodwarcls Duckoyman" is set down as, duck $\delta$, teal 4 , and "wigsin" 54-in all 66 birds. The Decoy season the first year lasted from September to January inclusive, during which period there were captured 675 clucks, 338 teal, +5 "pyntail," and 6,2\$6 "wiggin"-in all $7,3+5$ birds in the follow-

\begin{tabular}{|c|c|c|c|c|c|c|c|c|c|c|c|}
\hline & & & & & Ducks & & Teal. & & yntail. & & Wigsin \\
\hline September & $\ldots$ & $\cdots$ & $\ldots$ & $\ldots$ & 39 & $\cdots$ & SI & $\ldots$ & 9 & $\cdots$ & 3907 \\
\hline October & ... & $\ldots$ & $\ldots$ & $\ldots$ & 26 & ... & 10 & $\ldots$ & I & $\cdots$ & 1899 \\
\hline November & .. & $\ldots$ & $\ldots$ & $\cdots$ & 185 & $\ldots$ & 92 & ... & 3 & $\cdots$ & 24.4 \\
\hline December & $\cdots$ & ... & $\cdots$ & $\ldots$ & 219 & ... & 103 & ... & I 3 & $\ldots$ & I 53 \\
\hline January & $\ldots$ & $\cdots$ & $\cdots$ & $\cdots$ & 206 & $\ldots$ & $5^{2}$ & $\cdots$ & 20 & $\ldots$ & $8_{3}$ \\
\hline & & & & & 675 & & $33^{8}$ & & 46 & & 6286 \\
\hline
\end{tabular}
ing proportions :--

Then follows the entry; "Sold to Mr. Neptune this years whild fowll at $9 \mathrm{~s} 6 \mathrm{~d}$ per doz" - $£ \mathrm{I} 5 \mathrm{O}$. From this, however, it would seem that only 3 I 7 dozen, or $3.50+$ birds were sold, learing 296 dozen, or 3.552 birds, to te accounted for. Had the owner sold all the birds taken at $9 \mathrm{~s}$. Gd. per dozen, he might hare paid the cost of constructing the Decoy out of the first year's proceeds, and had a balance in hand of $\mathcal{L I}_{15}$. This shows what a profitable source of income in those days a Decoy was when properly managed. At the present day probably (could the same number of fowl be captured), the money value would be five times greater.

On glancing at the table last given, several points of interest are sugcrested. In the first place, it appears that, as now, by far the larerer number of fowl taken in Essex at that date were IVigeon. In the next place, it scems that the great body of these birds arrived in autumn before the cold weather had set in, and that after. Norember comparatively fow were 
taken. The Ducks and Teal, on the other hand, did not appear in force until mid-winter; while "Pyntails" were always scarce and irregular in their appearance. These conclusions are not based merely on the returns for the first year, 17I 4 , but are borne out by the returns for subsequent years. In 1716 the price paid for wildfowl thus captured rose to Ios., and the following year to 1os. 6 d. per dozen, the purchaser being "Jno. Deal." In 17 IS Joseph Woodwards ceased to be "Duckoyman," and in his stead one "Ben Carter" was employed, but either he was not so skilful as his predecessor, or wildfowl were never afterwards so plentiful. He never succeeded in taking more than 4,500 Wigeon in a season (this was in 1722 ), while Itoodwards never took less than 5,200 of these birds in a season, and once captured 6,296 in five months. The months of December 17r8 and January 1719 were, so to say, singularly unproductive. During the former month the Decoy was only worked on two days, the and and 3 oth, when only forty birds, all Ducks, were taken. In January four days' work only produced fifty-three Ducks and twelve Wigeon.

In I720-2 I the season was prolonged until the 3 rd of March, but to very little purpose; for on that day only fourteen I)ucks were taken, and the total number captured during the previous month of February was only thirty-three.

In I $72 \mathrm{I}$ the price of wildfowl rose to I2S. per dozen, Mr. John Deal still finding a market for all that could be spared from this Decoy. The following year he gave i 2s. per dozen to Michaelmas, and I fs. per dozen from that date to the end of the season.

In I 723 appears the entry, "Sold to Mr. Wm. Foster this years wild fowll att sixteen shillings per dozn." The same purchaser took all he could get the following year at the same price; and in 1725 and 1726 i 6 s. per dozen was again the price griven by Messrs. Darnoll and Basset. With the close of this season the MIS. ends, and we are left in ignorance as to whether the Decoy was then given up, or whether the owner died and it changed hands, or what its fate was. It would be interesting to know when and why it was finally abandoned.

To judge by the following summary, which is copied from the last page of the MSS. (all in the same handwriting), it would appear as if one reason for giving up the Decoy was the gradual falling off in numbers of fowl observable during the last three years in which it was 
worked-or, at least, the last three years of which an account has becen preserved, and the consequent falling off in the profits, which dwindled from $\& \&$ i to $£ 69$, and eventually to $£ 33$ only. Whether this falling off was occasioned by the establishment, or successful working, of other Decoy's in the neighbourhood, or by the reclamation and cultivation of the surrounding marsh lands, does not appear; both these causes probably had their influence upon the birds. Here is the summary referred to :-

An Account of Wildfowli. Ketcht att Steirle Duckoy.

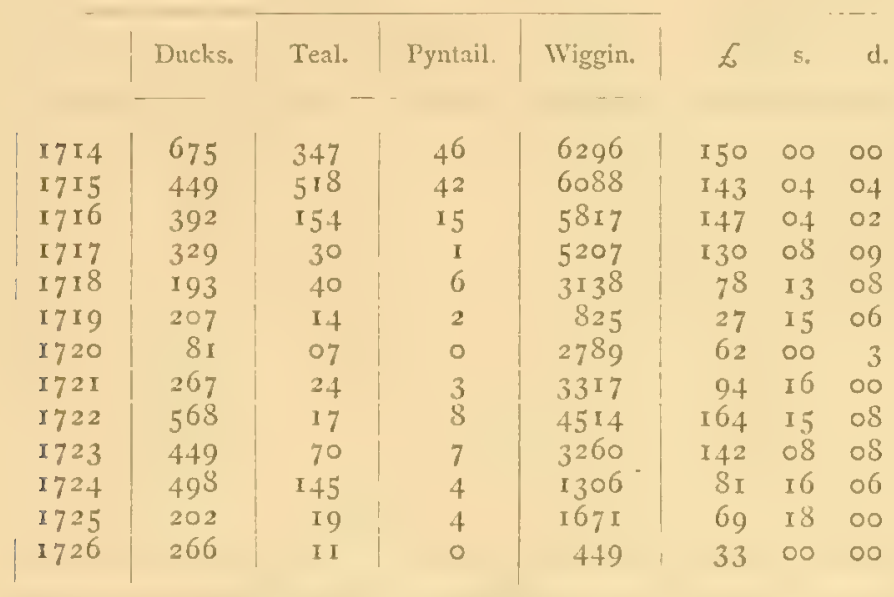

From this table it appears that the amount realized by the sale of wildfowl during thirteen years was $f 1,326$ is. $6 \mathrm{~d}$., or an average of $\delta \mathrm{IO} z$ per annum.

It would seem that nearly all the Ducks and Teal taken in this Decoy were forcigners, and not home-bred birds; for it is remarkable that during the months of August and September, before the large migrating flocks had arrived, comparatively few were captured, which would scarcely have been the case had these birds nested in any numbers in the surrounding marshes.

Since writing the above, I have found in the British Museum an old map of Essex, dated in MS. I 7 I9, and entered in the map catalogue as dated [ $1720 ?]$, wherein the site of this Decoy is clearly marled. It is placed on the east bank of Stecple Creck, between Steeple and the Blackwater. This map was prepared from a survey made by John WTarburton, IF.R.S., and Somerset Herald, assisted by Messrs. Bland and Smith." 
Latchington Decoy:-In Bowen's Map of Essex, 1760, wherein four Decoys are indicated, one is placed on the south bank of the Blackwater, on the west sicle of Latchington Creek, some 2 miles IV. of Steeple, and a mile E. of Mundon.

Having now clescribed the nine Decoys that exist or existed south of the Blackwater River, we will cross over to the northern shore of that estuary, commencing near Maldon and taking the Decoys seriatim from west to east. They are ten in number, and the first to deal with are those at Goldhanger.

Goldhunger (I), on the north shore of the Blackwater, a mile SIV. of Goldhanger, and $2 \frac{2}{2}$ miles E. of Maldon. This old Decoy is within 150 paces of the shore, and a $\frac{1}{4}$ mile S. of Gardener's Farm House, near Cobb's, Jehu's, and Brand's Farms.

It had five pipes.

Goldhanger (2). Half a mile SE. of Goldhanger, on the verge of the shore, was another Decoy. It was placed N. of Goldhanger Creek, on the point of land that divides the creek running up to Goldhanger and that going to Joyce's Farm House. This Decoy is $\mathrm{I} \frac{1}{4}$ miles $\mathrm{E}$. of the last described, and was a very fine one with eight pipes.

Both of these pools are in Goldhanger parish, and were worked within the recollection of an old gunner still living, aged 79, and linown to Colonel Russell, the well-known wildfowl shooter, to whom, together with Dr. Laver of Colchester, I am greatly inclebted for their researches anent Essex Decoys. Of the first-mentioned of these Decoys the traces may be still seen. It is situated on Cobb's Farm, the property of the Rev. Coope Arnold, of Hertford House, Coventry, and now in the occupation of Mr. Frederick Wakelin, and covers some i 6 or I 7 acres of marsh, surrounded by trees. It used to be worked by Cooper of Goldhanger until within the last 15 years. One of these Decoys was formerly a Pochard pond, but when the lead of these birds dropped off it was made into a Duck Decoy.

Folkard, in his "Wildfowler," page 96 , writing in $\mathrm{I} \& 75$, in allusion to the Esscx "Pochard Ponds," say's, "that on one or two occasions within present memory the capture of Pochards, or Dunbirds as they are locally called, has been so great at OxE drop or pull of the net that a waggon and four horses were required to remove them; and he adds that these birds 
have been known to resort in llights so numerous as apparently to cover every available space of water in the pond, and that 500 to 600 Pochards at one rise of the net was in those day's considered quite a moklerate capture."

These birds were taken by means of high nets affixed to poles.

The Pochard were alarmed off the pond, and at the moment they quitted it, the nets and poles previously laid flat on the ground, were freed, and springing up intercepted the Pochard in their flight, which on rising was very low for some distance.

The nets were placed near the edge of the pond, and were so arranged with balance weights that on pulling a string they instantly stood upright.

The pond had several such nets to suit the various directions in which the Pochard when driven flew away. At the foot of each net a (leep trench was dug, from out of which the birds were unable to escape, when tumbled therein by suddenly striking the nets.

Solley's Decoy, on the N. shore of the Blackwater, and $\frac{1}{2}$ a mile E. of the last one described, also on the edge of the shore.

This pool, a large one with eight pipes, formerly belonged to a Mr. Solley; it is known also as the "Wigeon Pond." It is opposite the Decoy last mentioned, but across the creek running up to Joyce's Farm, from which it is distant (S.) a mile, and is a mile SSE. of Goldhanger. It has not been in use for twenty years.

Gore Decey, on the N. shore of the Blackwater, and under $\frac{1}{2}$ a mile E. of Solley's Decoy, is another, known as the Tollesbury Gore Decoy ; it is situated close to and IV. of the Gore Saltings, from which it derives its name, and close to the sea. It is $\frac{1}{2}$ a mile SE. of Hervey's Farm and Joyce's Farm, and I $\frac{1}{2}$ miles SE. of Goldhanger.

Though worked in present memory, it has not been in use for many years.

Skinncr's I'ick, or IIhitchouse Dicoy', on the N. shore of the Blackwater, a pool that derives its name from being near two farms so called.

The Decoy is within a hundred paces of the shore and opposite to the Gore Decoy, across the creck in which are the Gore Saltings. It had eight pipes and is $\frac{1}{2}$ a mile S. of Skinner's Wick Farm House.

It is in Tollesbury parish, and is 2 miles SIV. of Tollesbury and I mile S. of Tolleshunt D'Arcy. This was formerly a very successful Decoy. 
but was given up some thirty years ago. Long since it was worked by Mr. Smith's father, who is alluded to in connection with the Oakley Park Decoy.

Bohmis Hall Decoy, on the N. shore of the Blackwater, and so called from a residence named Bohun's Hall to which it was formerly attached. It is $\mathrm{I} \frac{3}{4}$ miles E. of the last Decoy, and is on the N. side of "Old Mill Creek," a $\frac{1}{t}$ mile $\mathrm{W}$. of Mill Point and a little over a mile and a half S. of Tollesbury. As this Decoy is placed in what are known as the left Decoy marshes it is sometimes spoken of as the left Decoy. To the E. of the Decoy are the Mill Farm, and Tollesbury Wick marshes.

The Decoy was a large one, with eight pipes, and also possessed a set of nets and poles for taking Pochard. It has been out of use many years.

Old Hall Decoy, N. of the Blackwater, in the parish of Tollesbury, 3 miles E. of Tolleshunt D'Arcy, has been for several years in the occupation of Dr. J. H. Salter of D'Arcy House, Tolleshunt D'Arcy, near Kelvedon. It was previously rented with the adjoining shooting, by Sir G. Prescott, Bart. The Decoy is close to Pennyhole Fleet in the Old Hall Marshes, in the centre of the peninsula of land formed by the Salcot Channel and the Tollesbury Fleet North Channel. This Decoy, as I am informed by Dr. Salter, was one of the largest and best in the county, but labours under the disadvantage that the surrounding marshes are much used for grazing purposes, and are consequently always being disturbed, a circumstance which prevents the proper success of the Decoy.

The pool, a very ancient one, covers about 14 acres, and has eight pipes. The date of its construction is unknown. No regular account has been kept of the fowl taken, which were formerly reputed almost fabulous in number; and Dr. Salter states that beyond taking a few hundreds a year in hard seasons, he cloes very little with the Decoy, preferring to shoot the fowl in the adjacent marshes. The birds captured are chiefly Duck and Teal; very few Wigeon, which latter prefer the Decoys of Marsh House and Grange, south of the Blackwater. Together with other fowl caught, I)r. Salter mentions Pintail, Shoveller (which breed here in numbers), Tufted Duck, Long-tailed Duck, P'ochard, Golden-cye, Merganser, and Divers of different species. Among hirds not often captured in a Decoy, Dr. Salter mentions an Owl, a Snipe, a Partridge, and a Kingfisher. 
Old Hall (2). A mile to the E. of and near the Old Hall Decoy just described, in the same marshes, are to be seen traces of a small Decoy for Teal, long since disused, and of which no particulars are now obtainable.

Mersea Island, or West Mersea Decoy, on the N. bank of the Black-

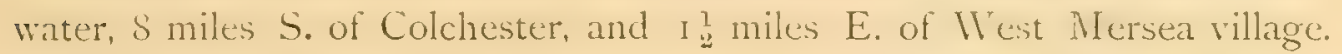
In a "Cieneral View of the Agriculture of the County of Essex," by the Secretary of the Board of Agriculture, Svo, London, isoz, the following account is given of the Decoy on Mersea Island (vol. ii. p. 36 I) :-

"One of the best, if not the most considerable Decoy in the county, is on Mersea Island, and rented, with a small farm of about sixty acres, by Mr. Buxton, of Layer de la llaye. He was so obliging as to accompany me from thence into MIersea, and to show me his Decoy. Not having before viewed a Decoy in the taking season, I had not remarked the precaution of each person taling a piece of lighted turf on a table-fork in his hand to approach the Decoy; as the wild ducks, it is said, would smell the person without caution, and immediately quit the pond. I found the expenses of this Decoy considerable: two men attend it, who are paid above fioo a year ; repairs, net, rents, \&c., amount in all to about $£ 300$ a year. Ducks are sometimes as low as $I_{4}$ s. a dozen. The contrivance for taking Dunbirds was new to me. At the Decoy for them near Ipswich [the Brantham Decoy is here alluded to.-Author], there are a series of very high poles, to which the nets are attached, for taking them in their flight; and these poles are permanent. At this Mersea Decoy; to which this bird resorts in large quantities as well as ducks, the net poles are lowered when not at work. Mr. Lee has a Decoy at Goldhanger, in which he took at one haul one waggon load and two cart-loads of I)unbirds; but the disturbance made frightened such as escaped so much, that he took no more that season."

Mersea Island is often spoken of as East and West Mersea. The island is not divided, and it is called thus to distinguish its extremities. It is close to the north bank of the Blackwater Estuary. The Mersea Island Decoy was discontinued I5 years ago on account of the shoregunners, who were able hy reason of its proximity to the coast, to disturb it with shooting. It was originally a Pochard pond, and is situated on land known as "Bacon's Farm."

Haring now dealt with the Decoys on beth shores of the Blackwater. 
those that are positioned along the coast from the mouth of the River Colne to Harwich shall be next treated; and finally the Decoys between Harwich and Manningtree, near the S. bank of the Stour.

Inland Decoys, as before pointed out, did not exist in Essex. They all lay either close to, or within a very short distance of, the tide.

Lion Point Decoy.-A Decoy existed within a $\frac{1}{2}$ mile of Old Lion Point, near the coastguard station, 2 miles SSE. of St. Osyth, and $2 \frac{1}{2}$ miles E. of Colne Point. The pool is often spoken of as the "Wick" Decoy, as it was situated in the Wick marshes - on Cockett Wick Farm. It was made by the late Mr. George Simpson in I860, but was never worked, and is now the property of Sir J. H. Johnson

Oid Mose Hall Decoy, near Beaumont-cum-Moze, and 32 miles NE. of Thorpe le Soken. There was formerly a Decoy here, on land belonging to Guy's Hospital, situated close to the tidal estuary called Hanford Water, near its NVW. extremity at the head of Oakley Creck. In i 8 Io an action was brought by the then owner, Mr. Carrington, against one Taylor, for firing a gun near the Decoy and frightening the fowl away, which grave the defendant an opportunity of shooting them. The case was tried by Lord Ellenborough in the Court of King's Bench, and resulted in a verdict for the plaintiff. It will be found reported in I I East, p. 571, and 2 Camp., p. 258.

The pond, as I am informed, has not been in use for the last forty years. Duck and Wigeon were the fowl chiefly taken here, but the proximity to a rival pool at Great Oakley Hall led to continual interference with the success of either, and eventually resulted in both Decoys being abandoned. The Old Mose Hall Decoy was last worked in 184 I by the widlow of Mr. Joseph Salmon, who for some years rented the Decoy and mansion from the Governors of Guy's Hospital. The pool was 100 yards wide, nearly round in form, and had six pipes.

The island called Pewit Island was near this Decoy, and it was so called on account of the vast gatherings of these birds that frequented it formerly.

Grat Oakley Hall.-There was formerly a Decoy here with six pipes, on the property of Miss Maria Bull, also situated near Hanford Water, and within 300 yards (N.) of the Old Mose Hall Decoy, just described. It has not been worked for many years, although used within the recollection of 
Mr. James Smith, now living at Harwich, who states that his father and grandfather before him were Decoymen at Great Oakley I Iall. Mr. Smith say's that he has killed 36 dozen in onc day, 100 dozen in one week, and in one season joo dozen wildfowl off this pool, though only an acre in extent. It is said that the Decoy, while in working order, was very lucrative to the owner, bringing in several hundred pounds a year. Its proximity, however, to the rival L)ecoy at Old Mose I Iall, situated close by, led to so much dispute between the Decoymen (each trying to decoy the other's birds) that both pools were eventually given up.

Mr. James Smith, above referred to, is the last remaining of the old race of Essex Decoymen, and he not only worked the Great Oakley Hall Decoy with much success, but in his youth the Marshhouse Decoy (Mr. R. Page's) as well.

Mr. Smith, though now eighty years of age, is a fine specimen of an old Decoyman, and his recollections of Decoys and Decoying are both accurate and interesting. He is, however, very poor, and has to work hard for his living as a shoemaker; although, when adorned with the Corporation coclied hat, sold lace petticoats, and bearing the mace of his Morship the Mayor of Harwich, he is very imposing, for he is still upright as in his youth, and well over $6 \mathrm{ft}$. high.

The following letter from Colonel Leathes (see Fritton Decoy), in regard to old Mr. Smith and the Oakley Hall Decoy; is so grood that I cannot refrain from giving it in full, besides which it contains no little information :-

\section{Great Oakley Hall Decoy.}

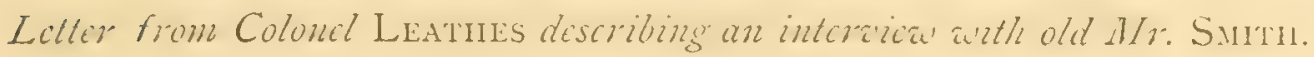

"I have had a long conversation with old Mr. Smith, who was the celebrated Decoyman on the Oakley Hall estate "uwards of fifty years ago. Smith appears, though now a man of eighty, to rememler everything in connection with the working of the Decoy rery clearly. He tells me his father began to employ him at the age of fourteen, and that at that period the take of duclis was enomous, considering the size of the Decoy pond. Oakley Decoy consisted of one acre only of water ; it iras circular, and fenced all round with a high wooden pralisade, 
the Decoy pipes being made in the usual fashion all round the pond, so as to be worked according to the wind. The largest take of ducks he ever remembers in one season was 700 dozen; but, he added, I mean 700 dozen whole fowl. Now, if we suppose that 300 dozen out of the 700 dozen were Teal and $W$ igeon, of which there were large quantities in those days, we have in reality these figures:-viz., 400 dozen whole fowl and 600 dozen half fowl, four half fowl, as you are aware, counting as one couple of ducks; in other words, you have this result of one season's catch on one acre of water :-

$$
\begin{aligned}
\begin{array}{l}
400 \text { dozen whole fowl } \\
600 \text { dozen half fowl }
\end{array}= & \text { 4,800 ducks. } \\
\text { Total } . & \text { I } 2,000 \text { Teal, Wirds. }
\end{aligned}
$$

This certainly is an enormous take off one acre of water, and beats my remembrance of our old Decoyman at Fritton Lake, John Fiske,-taking 600 ducks in one night, as I have known him do on several occasions. Still, as my father's aunt, Mrs. Merry, who lived at our Decoy at Herringfleet Hall, on Fritton Lake, about sixty years ago, never made more than $£ 300$ a year clear by the clucks, I don't think our success was ever equal to that at Oakley Hall, especially when you consider how very small the water of the latter place was.

"Mr. Smith states: 'We usually took the ducks at sunset and sunrise, and used liver-coloured fox-terriers if they could be got, and were handy ones. We used liver-coloured because the brighter the colour of the dogs the better the ducks worked to them. A piece of burning turf was an essential, the nose of the duck being so acute. IVe fed the Decoys with the following :-Oats, buckwheat, and hempseed oil, the latter being sprinkled over the former to give it Havour, and at times we also used malt coombs with a dash of oil of aniseed over them, this latter concoction ducks being very fond of. I never remembered,' adds Mr. Smith, ' more than eighteen dozen ducks taken in one drive, namely, 2I2.' Now I remember," says Colonel Leathes, "about ten years ago 300 ducks being taken on Fritton Decoy in one drive. Old Smith narrates, "My father and I had a good deal of trouble in keeping the Decoy open on very cold, frosty nights; but we would break the ice as well as we could till the ducks 
returned home from the feed in the early morning, and then we would throw a quantity of barley on the then fresh formed ice, and the weight of the ducks getting upon its surface woukl cause it to break again, and allow a mass of birds to keep swimming about all day in a small compass of water, and so doing the work for us of keeping the Decoy open. Sometimes a ferret was used, but nothing equalled a good, liver-coloured dog.

" The ducks we used as I)ecoy ducks were always a good, dark grey in colour, ducks that would quack well. They well knew their work, and when the drives took place would go on quietly swimming about as if nothing had happened. Hard by the Oakley Hall Decoy pond was the Decoy at Mose Hall.' MIr. Smith describes with animation how this I)ecoy came to be discontinued, and how his and his father's occupation was at last ruined by the spite of the Decoyman at Old Mose Hall.

"The two Decoymen were sworn and jealous enemies, and the one at Old Mose Hall, to annoy the other, used to buy all the assafoetida he could afford, and building it into a lump on the top of a bonfire when the wind was dead on for the rival Decoy, he used to set fire to it. To use Mr. Smith's words, 'The stink then was awful, and neither man nor duck could stand it and had to leave the position in the hands of the enemy: No, that vile stuff stunk out the whole place, and finally killed my father of grief and destroyed the fine Decoy.'

Horscy Island.-A large island in Hamford Water 2 miles NIV. of Tialton-le-Soken, on which a Decoy formerly existed, and was last worked by a man named Abraham Annis, about 50 years ago.

The pool with six pipes is still to be seen; it is placed close to Walton Creek in the stone marshes, and was discontinued owing to the difficulty of supplying it with fresh water.

Dorcrcourt Decoy, I mile E. of Ramsey, on a marsh adjoining South Hall. The outline of the pool can still be traced, though it has not been worked for 60 years.

The Decoys that existed along the shore of Essex travelling north from the Colne to Harwich heing now described, we will turn due west from Harwich to Manningtree, along the S. bank of the Stour estuary.

At a distance from Harwich of 7 miles (IV.) we come to a group of four old Decoys, all within 3 miles cast of Bradfield. Of these four pools, 
though worked in present memory, no particulars are now procurable. They are as follows:-

Roydon Hall Decoy, 2 miles IV. of Ramsey and 3 miles E. of Bradfield, on the S. side of Stour Wood, near Roydon Hall.

The Old Decoy, or Jacques Hall Old Decoy, is placed a $\frac{1}{2}$ mile E. of Jacques Hall, the same distance S. of Jacques Bay, on the Stour River, and a mile NE. of Bradfield, and 300 paces $S$. of the Harwich and Manningtree Railway. The pond is quite filled up and its enclosure alone remains.

Facques IIall Decoy, 3 of a mile S. of the last-named, is placed the above pool, of which little trace remains. It is distant I mile SE. of Bradfield, 300 paces E. of Bluchouse Farm, the same distance N. of Kingswood, and $\frac{3}{4}$ of a mile $N$. of Wicks.

Pond Hall Decoy.-A $\frac{1}{2}$ mile E. of Jacques Hall Decoy, and $\frac{1}{2}$ a mile $S$. of Bradfield, are the remains of the above-named pool. It is near the residence of Miss Simpson, from which it derives its name; like Jacques Hall Decoy it is just a mile S. of the Stour River.

Both are in the parish of Wix, or Wicks, and the land they are situated on was part of the possessions of the large Benedictine Monastery of Wix.

Traces of this Decoy are still plainly visible, though it has not been in use for many years.

Wormingford Dicoy', 3 miles IVSW. of Nayland, on the S. bank of the River Stour, some I 2 miles above Manningtree.

This pool is 9 acres in extent, is slirted with reeds and bullrushes, and surrounded by willows and alders.

During the winter months it is much visited by wildfowl; but no record, its owner states, exists of its history as a Decoy.

Leaving the Stour and travelling south we come to

Villa Farm Decoy, $2 \frac{1}{2}$ miles SSW. of Elmstead, and i mile E. of Wivenhoe.

A Decoy existed here many years ago. The pond still remains, but is almost grown over with reeds and willows. 



\section{PLAN OF CRAB-SHAPED DECOY.}

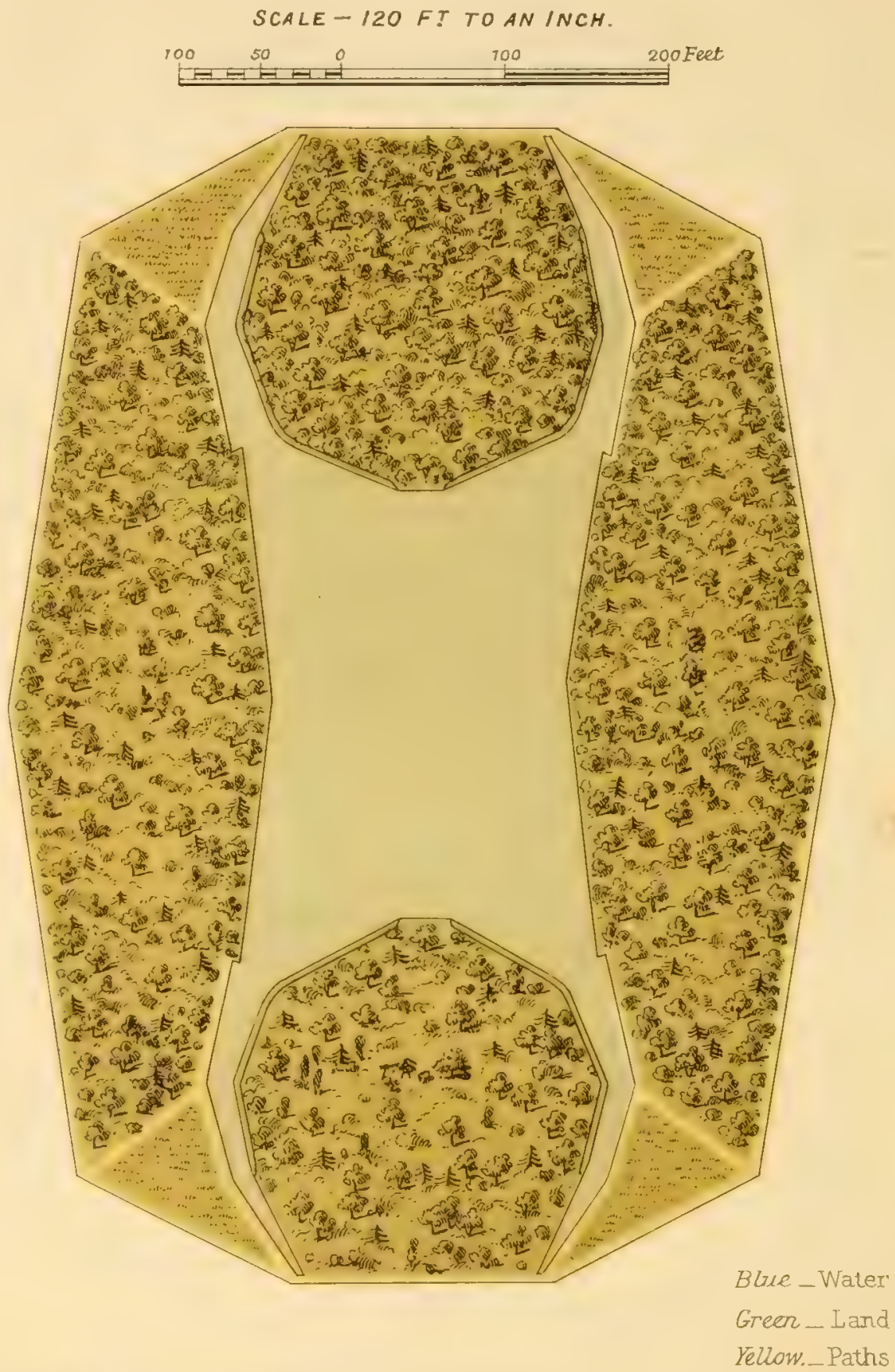

BERKELEY-HORNBY-SEDGEMOOP AND SHARPHAM. 


\title{
HISTORY OF DECOYS-(continued).
}

\author{
CHAPTER VII. \\ Decoys in the County of Glamorgan. \\ Decoys in zese. \\ Park Wern. \\ Decoys out of use. \\ None.
}

Park Wern Decoy, 9 miles W. of Swansea, on the property of Sir H. Hussey Vivian, Bart, who, in $1 \$ 65$, formed a small Decoy in Llanridian Marsh, east of the village of that name, at Killibion, near the estuary of the Burry river, on its south shore. It is about an acre in extent, with three pipes, and the average number of fowl taken annually for the last five years has been about $11+$ head, the greater number being Duck and Mallard. This small Decoy has only been worked to supply the owner's wants, and no attempt has been made to try how many birds could be taken in a season.

\section{Decoys in the County of Gloucester.}

\section{Decoy's in use.}

Berkeley Castle (2).
Decoys not in use.

None.

Berlichy Castle (Earl Fitzhardinge). 3 miles N. of the town of Berkeley, $r 2$ miles SIT. of Gloucester, and close to the south bank of the River Severn, within a mile E. of Purton. These are the only Decoys in the county. The pools, of which there are two within a mile of one another, are about an acre apiece in extent, and there are four pipes to each. The old pool is on the verge of the S. bank of the Berkeley and Gloucester Canal, which was formed so close to it that, fearing the Decoy would suffer therefrom, the new Decoy was constructed in 18 to between the canal and the Severn, on the New Grounds. 
The owner informs me that the operation of the Ground Game Act has nearly ruined these Decoys; the constant shooting scaring the wildfowl away. Before the passing of the Act, the average take every year was I,370, but it has now dropped to about 500 head. These pools are on the same plan as that of the Hornby Decoy in Yorkshire, as well as those at Sedgemoor and near Glastonbury in Somerset, and from which latter they were originally copied,- though afterwards improved by William Skelton. The pipes are right and left-handed ones. The new pool was constructed by the late Mr. Joseph Vilcox, of Nash, near Newport, who owned Decoys at that place. Falling nets are fitted to the entrances of the Decoy pipes, so that by pulling a cord they can be dropped down. A great many Ducks were formerly thus captured at the Berkeley Decoys when feeding in the pipes at night.

\section{Decoys in the County of Hampshire.}

Decoys in zuse.

None.
Decoys not in use. North Stoneham. Bournemouth. New Forest.

North Stoncham Decoy, 2 miles SW. of Bishopstoke, on the property of Mr. J. W. Fleming, of Stoneham Park, halfway between Bishopstoke and Swathling, about a mile to the east of the railway line to Southampton from Lonclon, and a quarter of a mile west of the River Itchen. This Decoy has two pipes, and was constructed some eighty years ago, but was disused about twelve years since, in consequence of the great disturbance of the fowl by shooting in the neighbourhood.

The Decoy is situated at a lower level than the River Itchen, with which it was, when in use, connected by a channel.

In hard weather the Decoyman was wont to run all the water out of the Decoy at dusk after the fowl had flighted, and then, by an arrangement of sluices, fill it again with fresh water from the river in the early morning before the ducks returned from their feeding grounds.

He thus was always able to offer unfrozen water to attract the birds when other Decoys were blocked up with ice. 
Boumemouth.-Lord Malmesbury states that on the streams at Bournemouth sixty years ago, before the present town arose, there used to be a Decoy, the site of which is still known as the "'coy P'ond." No particulars, however, of its working are now obtainable.

I must here refer to Soulcy Pond, 7 miles NE. of Lymington, in the parish of Beaulieu, on Lord Henry Scott's estate near the Beaulieu river estuary, and once the property of the famous Abbey of Beaulieu. This large piece of water is frequented in severe weather by numbers of wildfowl from off the Solent, and could be made into a first-class Decoy at any time. Though sometimes spoken of as The Decoy locally, it never was one, as it was formed to work by water-pressure the iron hammers used for shaping metal for vessels, as well as for other purposes, in the days when wood was the only fuel arailable for smelting purposes. The old forge is still well remembered in the locality, and the beat of the hammers could, in a SW. wind, be heard at Beaulieu, 4 miles distant.

Nere Forest.-An enclosure in the New Forest is still called the Decoy Pond, though it is now devoid of water. It is situated half way between Beaulieu and Lyndhurst, on the head waters of the Beaulieu river, near Ipley Farm, a little $\mathrm{N}$. of Yew Tree Heath and Blackdown. In a map of 1789 it is marked at that date even as "The olr Decoy Pond," so that, as may be supposed, there are no records of it to be found.

Decoys in the County of Hereford.

Decoys in use.

None.
Decoys not in use. Shobdon Court.

Shobdon Court, 5: miles E. of Presteigne (Lord Bateman's). There used to be a Decoy here on a pool of eight acres, with three pipes, and many years ago Lord Bateman had a new pipe made by George Skelton, junior, who came from Norfolk to construct it.

But this, together with the others, became silted up, and the Decoy has been practically useless for twenty years. Lord Bateman tells me that he remembers catching thirty-five ducks in it at one time. 


\section{Decoys in the County of Huntingdon.}

\section{Decoys in use.}

None.
Decoys not in zse.

Holme Fen.

The fens and meres of Huntingdon before they were reclaimed lay in the NE. of the county, chiefly between Ramsey and Petcrborough. The larger meres consisted of $I T h i t t l c s c y$ ( 3.000 acres) and Ramscy (1,500 acres), and the smaller, of those known as USG RTere and Trundle MIre, as well as other still smaller ones. The fens in partial cultivation surrounded these meres in all directions for many miles, and the principal of them were Farcett Fon, north of Whittlesey Mere, Holme Fcn on its south side, Stilton Fon on its west side, and Middle Moor or Fen on its SE. shore. South of Holme Fen was the vast tract of swamp known as The Great Fen.

From Earith, near the river Ouse, to Ramscy IMcre, the fens covered the entire country, extending a distance of I I miles uninterruptedly.

These fens and meres comprised an area of 44,000 acres, and the latter were finally drained and cultivated in 1852 .

As far as I can discover, no Decoys existed in Huntingdonshire save that known as Holme Fen Decoy, near Whittlesey Mere. The fens of this county were so frequently flooded that they were not adapted for Decoys, and the difficulty of growing trees or shrubs on such wet land also militated against their formation.

Holme Decoy, between Ramsey and Peterborough, in Holme Fen, $2 \frac{1}{2}$ miles E. of Holme, 6 miles S. of Peterborough, and a mile from the south shore of Whittlesey Mere, before the latter was drained.

A Decoy was constructed here in the year 18 I $_{5}$ by Richard Skelton, son of old George Skelton, who stated to my correspondent, F. Coles, now occupying a farm in Holme Fen, that for the first three or four years the Decoy was drowned by the floods, and hecaught no ducks. In the following year he took 200 dozen in seven days, which, counting Teal and Wigreon as half birds, probably represented 3,000 fowl. The pool was about an acre in extent, with three pipes, and was surrounded by ro acres of rough land, the surrounding fen being then uncultivated. Coles states that during the last years of its existence very few fowl were taken in this Decoy, for 
when Skelton began to cultivate the land round it, about the year $1 \$ 43$ or I 844, the birds deserted the spot. This was a few years before the Middle Level Drainage was commenced.

Mr. J. M. Heathcote, in his "Reminiscences of Fen and Mere" (pp. 4., 49), has given a brief notice of this Decoy, with a rough slictch of one of the pipes.

The Decoy was on property belonging to Captain Wells.

T. G. Skelton, who remembers this Decoy well, informs me he recollects his uncle Richard taking jo dozen bircls here each day on three consecutive days. Nor are these large takes at all unlikely, considering the nature of the surrounding country, which in those times abounded in large meres, and fens.

Whittlesey Mere was drained in I $_{52}$, and the Decoy about the same date given up. This large mere was 3 miles long and a mile wide. It was the resort of eight fowlers, who regularly attended it, to shoot wildfowl during the winter, and to cut reeds and catch fish in the summer. Three of these men are at this date (I8S5) now living. They shot the fowl from small shallow boats, using tlint guns \& ft. 6 in. long. some of which are still to be seen in the district.

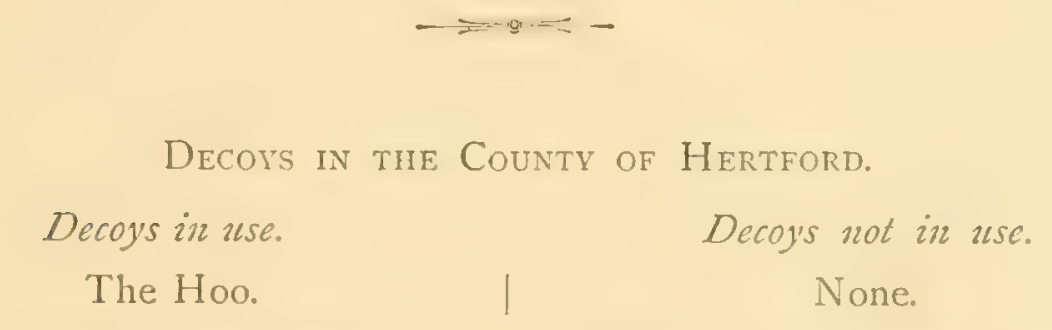

At The Hoo, near Welwyn, S miles WNIV. of Hertford, is a small trap Decoy belonging to Lord I acre, and used only to supply houschold wants. The one cage that is attached to the pool is $30 \mathrm{ft}$. long, I $2 \mathrm{ft}$. wide, and $9 \mathrm{ft}$. high, and is covered with wire netting. When the fowl swim up the ditch under the cage they are entrapped by means of a falling cloor, worked by a wire from a distance, as is the case at Harclwick (which sece), and other trap Decoys. The Decoy was constructed in I \$ ; 0 , and the takes are but a few dozen fowl in the season, as they are required from time to time for the table of the owner. 


\section{Decoys in the County of Kent.}

Dccoy's in use.

None.
Decoys not in use.

Grovehurst.

Kemsley.

Growelumst Decoy, 12 miles ENE. of Maidstone, in the parish of Milton, near Swade, in the marshes close to King's Ferry and within a mile south of the Swale Creek, that leads by Sheerness to Queenborough, Milton, and Faversham. There used to be a Decoy here, believed to have been 150 years old. It was known as Fullager's Decoy, Fullager being the name of the farmer who rented the grazing in the adjoining marsh. It was also spoken of as the "Sittingbourne Decoy."

When the railway to Sheerness was constructed, it passed close to the Decoy, and in course of some years utterly spoilt it. It has, in consequence, not been worked since 1866 . The pool was about 2 acres in extent, exclusive of the surrounding cover of willows and alders, and had four pipes.

It belonged to Mr. W. Gascoyne of Westgate-on-Sea, and for many years was worked by a man named Chapman, still living. From the carefully kept Decoy Book of expenses and catches lent me by Chapman in connection with this Decoy, I find that the largest take in one season during his time was 2,500 fowl. The best day's catching resulted in I 40 fowl, and the greatest number at a drive was So Duck and Mallard-this, too, within 40 miles of London. But formerly all the district surrounding this Deroy consisted of extensive marsh lands, intersected by numerous creeks and arms of the sea, and so very favourable to attract wildfowl.

Mr. Gascoyne has very kindly furnished me with the following interesting account of this Decoy. He says :-

"In 1847 my late father purchased the farm called Great Grovehurst, upon which was an ancient Decoy in working order. A Lincolnshire Decoyman came every season to take the wildfowl, and as I was in occupation and living within two miles, I became greatly interested in the pond.

"Although never a commercial success, over I,000 Ducks and I,000 Teal have been taken in one season, but some years they fell off to a quarter of that number. Owing to this falling off, my Lincolnshire man eventually found it not worth his while to come, and I had to teach a local 
man of the keeper class. Eventually a great misfortune befell the pond in the opening of the Sheerness Railway within 250 yards of it. Cement works were also built within a mile, the neighbourhood becane much more inhabited, and the use of the gun was universal. But the death-blow to the pond was the lowering of the general drainage of the surrounding marsh land + fect. This dried up acres of shallow water; the ducks ceased to arrive in any numbers, and some eighteen years ago the pond of $1_{2}^{1}$ acres of water and its cover of about 6 acres were cleared and planted with fruit trees.

"The birds were taken in the usual way, being fascinated by a dog ruming up net-covered ditches called 'pipes,' the doy being trained to appear and disappear, always going from the pond and towarls the tunnelnet at the extreme end of the pipe. As many as 20 ducks would be taken at a time without the birds in the pond being alarmed. The dor at times would wear a coat of many colours just for a change, and be successful. I once made a good take by accident. A stoat hunted a rabbit up the 'pipe, running through a hole in the screen near the ducks. Being on the watch, I was astonished to see birds swimming up the pipe, and in a moment I was behind them; they flew from me into the smaller end, and were caught.

"The fowl taken at my Decoy were Ducks, Teal, IVigeon, Pintail, Gadivall, Yochard, Golden-eye, Tufted Duck and Shoveller.

"Teal began to arrive by the end of August: the ducks a month later. Some of the ducks were bred in England, and we called them 'Tame-flyers.' A few were crossed with tame duclis, and formed a grood 'lead,' as they left the pond at sunset and returned every morning just at dawn, often with numerous companions, who would fly round several times before alighting, the regular visitants coming straight in from any height with a rush! so that the Decoyman on the watch could tell how many ' fresh birds' he had each day. 'The pond was supplied by an artesian well; and during rainy weather floods passed through and helped to prevent its freezing up). Severe frost often caused great expense, as men had to keep a boat moring all night, only learing off just as the birds came in at clawn. At such times three out of the four pipes would be frozen up, the birds seated out on the ice coming occasionally to drink at the open pipe. The catching wats then assisted by a free use of canary seed and other small seeds and 
corn, the tame-flyers coming up freely and eating greedily. The fresh birds would soon follow, and being very hungry would swim far enough under the net to get caught. At such times a few wild ducks would have the pinion feathers cut from one wing; they soon got tame and attracted numbers of Mallards, especially in the spring.

"About one mile to the SE. of Grovehurst Pool is another smaller abandoned Decoy on my property, called Kemsley; this has not been in use for Ioo years, but I am told was used for taking Teal, the larger pond being frequented by ducks. I well remember the Teal in my Grovehurst Decoy, sometimes to the number of 500 , trying to sit out of the way of the ducks, even seating themselves on the top of the low hedge, fencing in the pond from the surrounding cover, so as to be out of the reach of their larger neighbours."

About six years ago Mr. G. Webb of Tunstall, near Sittingbourne, commenced to cnclose about 240 acres of salt land near the mouth of the River Medway, at the lower end of Chitney Marshes, only a few miles from the Grovehurst Decoy, and he has lately formed a large square pond, planted round with alder, willow, and seclge, in the hope of attracting wildfowl, though no "pipes" have yet been constructed. But the water from the creek that fills the pond being salt, the ducks will not drink it, and consequently do not remain long, although a good many have been seen there at one time during the past season $(1884-5)$.

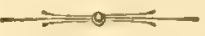

Decols in the County of Lancaster.

Decoys in use.

Hale.
Decoys not in use.

Orford Hall.

Hale Decoy', 9 miles SE. of Liverpool and $7 \frac{1}{4}$ miles S. of Prescot, on a small peninsula on the $\mathrm{N}$. bank of the Mersey River, and opposite Frodsham and Runcorn in Cheshire.

The only Decoy worked in Lancashire is that at Hale, belonging to Colonel J. Blackburne, M.P.

This Decoy is situated near the village of Hale, is within 150 yards of a high road and 450 yards of the Mersey Estuary. The pool is an acre in 
extent and has five pipes; it is in a small plantation, and has a moat round it I $S \mathrm{ft}$. wide, which is filled during high tides - a useful arljunct to ensure the privacy of the Decoy as well as to keep out vermin from the l)ecoy grounds. This Decoy, though its takes are now comparatively small to what they were formerly, is kept up in admirable order by its owner, who talies much interest in it.

Its exact age is unknown, but there is conclusive evidence to prove that it has been in existence for I 50 years.

Many years ago it was partly re-constructed by one of the Skeltons.

In 1754 the Decoy was much improved by the then Mr. Blackburne, who at that date came to settle at I Iale from Orford Hall, near IVarrington, where there had also long been a Decoy, though abandoned now for many years.

The owner of the Hale I) ecoy has in his possession the Decoy book connected therewith, and which has been kept since 1 SoI.

Teal predominate amongst the fowl nuw taken, though formerly IVild. duck were most abundant. For instance, in the following scasons it will be seen the latter bird was in the majority:-

\begin{tabular}{|c|c|c|c|c|}
\hline $\begin{array}{l}\text { Date. } \\
\text { I } 8 \text { I } 2\end{array}$ & $\begin{array}{l}\text { Duck. } \\
278\end{array}$ & $\begin{array}{c}\text { Wigeon. } \\
39\end{array}$ & $\begin{array}{c}\text { Teal. } \\
7 \mathrm{r}\end{array}$ & $\begin{array}{c}\text { Total. } \\
3^{88}\end{array}$ \\
\hline I 8 I $3_{3}$ & $3 \circ 7$ & 35 & 108 & $45^{\circ}$ \\
\hline $\mathbf{I} 8 \mathbf{1} 4$ & I 33 & 10 & 60 & 203 \\
\hline 18 I 5 & $18 z$ & IO & 54 & 246 \\
\hline 1816 & 174 & 47 & 82 & $3 \circ 3$ \\
\hline 1817 & 255 & 3 & 99 & 357 \\
\hline $18_{20}$ & 227 & 3 & 2 & $23^{2}$ \\
\hline 1825 & 123 & 5 & 0 & 128 \\
\hline
\end{tabular}

However, in 1875 came a change, for Teal suddenly appeared in the Decoy, and were caught in a much greater proportion than before, the Duck now being in the minority. For example, in

$\begin{array}{lrrrr}\text { Date. } & \text { Duck. } & \text { Wigeon. } & \text { Teal. } & \text { Total. } \\ 1875 & 444 & 0 & 718 & 1,162 \\ 1876 & 274 & 18 & 645 & 937 \\ 1877 & 191 & 29 & 563 & 783 \\ 1878 & 92 & 2 & 298 & 392 \\ 1879 & 126 & 3 & 323 & 452 \\ 1884 & 56 & 5 & 611 & 672 \\ 1885 & 52 & 8 & 759 & 819\end{array}$


These statistics are both instructive and curious, and tend to show what a "lead" of fowl will do for a Decoy. The Teal that now resort to Hale must, with rare exceptions, be birds from far-off regions that have gradually imparted to their descendants the fact that such favourable shelter as the quiet pool offers them, is existent.

Thus those that are not caught return to their nesting haunts year by year, and so the information is handed down.

As to the Wild-duck, these were most likely homebreeding birds, who, when they left the Decoy at the end of the season, retired to the wild spots, known as "moss lands," which formerly abounded in Lancashire, to rear their young.

Since these feeding and breeding-grounds have been drained the Wildduck have, it may be said, deserted the county; and it may have also occurred that the Decoyman was not careful to leave in the Decoy, at the end of the season, enough Duck to bring back a "lead" the ensuing year, should foreign birds have been in the habit of visiting the pond. Both causes would account for the small number of Duck now taken at Hale.

Orford Hall, within a mile of Warrington, at the head of the Mersey estuary, on its north bank. Formerly, as above stated, the residence of the Blackburne family, and now in the possession of Mr. W. Beamont. This gentleman states that some 50 to 60 years ago he recollects the Orford Decoy being last used. The remains of the Decoy are still to be traced, though almost grown up with underwood. 


\title{
HISTORY OF DECOYS-(contimed).
}

\author{
CHAPTER VIII.
}

\section{LINCOLNSHIRE.}

TRuLY this county was the home of Decoys, for I am able to give a list of no less than $3 S$ of these contrivances as formerly existing in Lincoln, only one of which is now worked-that at Ashby. The Decoys of Lincoln chiefly flourished in its eastern and southern portions, notably between Sleaford and Crowland, and from Wainfleet to Boston. A line drawn from Sutton St. Mary's, near Crosskeys IVash, siui Crowland, Market Deeping, Bourne, Falkingham, Sleaford, Tattershall, Spilsby, and W'ainfleet, to the sea at the latter place, would enclose the large majority of the Lincolnshire Decoys, as well as many of the great fens in which they existed. The principal of these fens, and beginning north near II ainfleet, were the East and IVest Fens, on the eastern side of which the Friskney, Wainfleet. and Wrangle Decoys were situated-Wildmore Fen. Holland Fen (22,000 acres), the Kyme Fens, Sempringham Fen, Pinchbeck Fens, Bourne Fen, Deeping Fen (I 5.c00 acres), Cowbit and IThaplode Fens; besides these there were the great marshes of Gedney, Holbeach, and Moulton, east of Spalding and between that town and the sea.

North-west of the district just described the Fens reached from Tattershall to Lincoln; these latter were drained at the close of the last century, and 20 to 30 square miles of country was enclosed in consequence.

In I So8 (about the year most of the Lincolnshire Decoys were discontinued) it was calculated that near 200,000 acres of fen had by drainage come under cultivation in Lincoln. In the time of Elizabeth the reports of the day state that the East Fen was usually under water throughout the winter ; nevertheless, no attempt to properly drain it or the other low lands of Lincolnshire was made until the close of the last century; and though 
numerous efforts had been previously made in that respect, the success resulting therefrom was meagre and disappointing. As an example of how far inland the tide penetrated in bygone days it is said that vessels were formerly able to sail to the city of Lincoln from the sea up the River Witham, the latter then considered to have been a broad estuary.

The western part of the county was also subject to disastrous inundations owing to the flooding of the Trent. A range of low sand hills confine the Trent from Western Lincolnshire; these hills extend from Girton in Notts to Marton in Lincolnshire, all along the course of the river on its right bank.

At the low places in this natural dam immense protective dykes have been built to confine the floods and direct them north to the Humber.

One of the dykes, that near Spalford, gave way through the pressure of water in 1795 ; the inundation did great mischicf, and covered for weeks over 20,000 acres west of Lincoln, the floods even reaching the city.

In the NW. part of the county a large tract of marsh, known as the Isle of Axholme ( 17,000 acres), because it was surrounded by rivers and floods, was also finally drained at the end of the last century. But to return to the Fens. In I 768 a serious riot took place owing to the proposed enclosure of Holland Fen; at that date not a single acre of this Fen was dry land from October to March, and on January Ist, 1779, during a memorable gale, vessels from near Boston were driven inland two miles over the marshes, and at Lynn, on the same coast further south, the market-place was two feet under water.

Previous to the last extensive drainage in $1 \&_{10}$, Wildmore and Holland Fens were often under water throughout the winter to a depth of from 3 to $6 \mathrm{ft}$. The late Mr. Pedley, in his " Fens and Floods of Mid-Lincolnshire," gives a capital account of the Fens and Fenmen of this county. He says, "The Fenmen were good shots, and frequently used a horse for stalking the wildfowl; others were in 'shouts,' or 'shallops,' of which numbers might be seen drifting like logs of wood, and only showing signs of being occupied by the reports and smoke from the guns."

In the summer the water evaporated and left a crop of water-grass, which formed a ready shelter for the wild birds to nest in.

When the ground was dry it was stocked with immense numbers of 
horses, cattle, sheep, and geese; one man alone, Mr. l'edley says, having sometimes a stock of 2,000 old-brood geese.

The Wildmore Fen was chicfly occupied by horses, a particular breed of the latter known as Wildmore Tits being in great request. These animals were generally of a grey colour, not large, and were said to be of Arabian descent.

Great numbers of sheep were also depastured in Wikmore Fen, one owner clipping as many as 1,200 sheep in a year. Mr. P'elley says that, in $1793,40,000$ sheep rotted on Holland and Wildmore Iens alone; nor was this the only evil, for the number stolen was incredible; they were driven off by night in whole flocks.

The East Fen, not effectually drained till I 867 , had been a morass and bog from the carliest times; large pools of stagnant water being dispersed throughout it. In Dugdale's time these pools numbered sixtyone, besides many smaller ones, and they were all so connected by channels of water that a boat could pass from one to the other. Close to these pools were the Friskney and Wainfleet Decoys. Mr. Peelley, before quoted, grives an amusing account of the East Fenmen. It appears that in the summer season, when the waters had receded, large districts were exposed, covered with coarse grass called fodder. Every person having a right to this Iicn hat the privilege of employing two labourers, and with them they would go into the Fen the evenings before midsummer-day and lie down to wait for a yun fired exactly at twelve o'clock (midnight), then all would rise and set to work. By mutual agreement all the fodder each party could mow a path round became private property. After completing one circle they hastened to find fresh ground to encircle in like manner, as long as any grass remained unclaimed.

After this they completed at leisure the mowing of those parts they had previously cut a path round, and so every one usually obtained an ample supply of food to serve his cattle with throughout the winter.

That Lincoln abounded in wildfowl more than other counties in lygone cliys there is no doult. The vast bay known as the "Mash," as well as the sluggish rivers that emptied therein, woukd bring numberless fowl to the shores of the county, afterwards to find their way to the inland marshes and fens, wherein they doubtless nested in immense numbers. In the extreme north of the county the great estuary of the Humber 
would have a similar effect. Onc-third of the county consisted of marsh and fen, and this vast portion was subject to frequent floods during winter, and from what I have said it may well be conjectured that to the close of the last century Lincolnshire Decoying must have been a very profitable trade.

Whilst treating of the Fens of this county I cannot omit the following admirable account of the same, most kindly supplied me by Mr. Thomas Southwell, F.Z.S., of Norwich, whose name frequently appears in these pages. He says :-

"It is not to be imagined that a great improvement like the drainage of the Fens, which involved such an entire change in the face of the country, and, consequently, in the habits of the people, could be carried out without serious opposition. The first act for the drainage of the Bedford Level was passed in 1573 ; but, owing to vexatious litigation, and even more active opposition still, the work was not accomplished till i 653 . Dugdale tells us that the almost barbarous sort of lazy and beggarly people, who lived by fishing and fowling of course, dreaded the loss of their occupation, which was sure to follow the subsidence of the waters, and opposed the improvement by all means in their power, one of which was the making of 'libellous songs to disparage the work.' He gives one of these songs, which is curious, but too long to quote entire. It is headed the 'Powtes' Complaint,' and in it the fishes call upon the waters to assemble, under the lead of 'good old Captain Flood,' 'who was never known to fail us,' and beg Eolus, Neptune, and the Moon also to lend their aid :-

" 'For we shall rue it, if 't be true, that Fens be undertaken, And where we feed in Fen and Reed, they'll feed both Beef and Bacon.'

"Away with boats and rudder, farewell both boots and skatches, No need of one nor th'other, men now make better matches; Stilt-makers all and tanners shall complain of this disaster; For they will make each muddy lake for Essex calves a pasture.'

"Sir Cornelius Vermuyden, the celebrated Dutch engineer, who had settled in this country, and had already done good work, suffered so severely from popular prejudice, that not only was his scheme for draining the Bedford Level rejected, in consequence of his being an 'alien,' but also at Dagenham, where, having in 162 I repaired the banks which hitherto had been too weak 
to protect the level against the violence of the tide, the people refused to pay the tax levied for his remuneration, whereupon the King assigned him certain lands by way of recompense, which, let us hope, he got. Lut eren worse fortune befell the worthy Knight in 1642 , at Hatfeld Chase. There. previously to his draining operations, the country was full of wandering beggars, but, afterwards, from the demand for agricultural labour, wages were cloubled. Nevertheless, after Vermuyden and his partners had entered upon possession of what belonged to them by agreenent, and had built a town called Sandtoft, 'with a church therein; placing a minister there; whereunto resorted above two hundred families of French and Walloon l'rotestants (fled out of their native country for fear of the Inquisition, only to enjoy the free exercise of their religion here), the inhahitants, claming common right, and under pretence of raising an army for the protection of the King, 'broke down the fences and inclosures of four thousand acres, destroyed all the corn growing, and demolished the houses built thereon.' After this they broke other banks, watching the breaches with muskets in their hands, to prevent their heing repaired, and forcing the inhabitants " to swim away like ducks. ${ }^{\circ}$ This lawess destruction continued till seventyfour thousand acres of land were under water. Fullert thus refers to the discontent of the Fen people: "Tell them of the great benefit to the publick, because where a Pike or Duck fed formerly, now a Bullock or Sheep is fattened; they will be realy to return that if they be haten in tuking that Bullock or Sheep, the rich owner indicteth them for felons: whereas that Pike or Duck were their own goads, nnly for their pains of catching them. So impossible is it that the best project, though perfectly performed, should please all interests and affections.' In fact, they would exclaim with Hudibras:

* "This incident suggested to Harriet Martineau the subject of the charming little story, the first of the 'Playfellow' series, entitled the 'Settlers at Home.' Long after the Fens were drained, the 'Redfurns' were still represented by the hardy race of men who took up their abode on some lonely marsh on the shores of the Wash, often in a hut-boat lying high and dry in some creek, and gained a precarious living by their nets and guns; or by the men who squatted down in the midst of the 'Broads,' as graphically described by the Rev. Richard Lubbock in the oft-quoted passage (pp. I29, I30, second edition) of the 'Fauna of Norfolk.' These are even now represented by the shore-gunners of the Wash, and the eelsetters and fishermen of the Norfolk l3ronds."

$\dagger$ "Worthies of Lingland," 4to Edit. (1811) vol. i. p. I52. 
" The law condemns the man or woman

Who steals the goose from off the common,

But lets the greater felon loose,

Who steals the common from the goose!'

" Dugdale very ingeniously argues, with regard to the dreaded scarcity of fowl, that when the country is drained there will be an increase in the number of 'rivers, chanels, and meres,' which form the principal resorts of the fowl, and their numbers will probably be augmented in consequence; also, that the fish and fowl will be more easily taken within the restricted bounds than in the more open water; added to which, the decoys planted on the drained lands woukl capture a much larger number of fowl than could be secured by any other means formerly used. IVe fear that all these arguments would be insufficient to convince the hardy Fen-men, who lived by their nets and guns, that the latter state of things was preferable to the former.

"The chief feature in the animal life found in the Fens in days gone by must have been the great abundance of birds and fishes. When IVilliam the Conqueror lay with an army before the Isle of Ely, vainly attempting to force the remnant of the English who had taken refuge in this their last stronghold to surrender, it is said, that, but one only of his solliers succeeded in entering the isle alive. This man, Beda by name, was taken prisoner by Hereward's men, and after being treated with kindness was allowed to return to the King's camp. The account he gives to Villiam of what he witnessed in the Isle of Ely, of the strength of its position, 'compassed about with huge waters and fens, as it were with a strong wall,' of the multitude of wild animals both in the woods and near the Fens: as also of fish found in the waters, and fowl which are bred there, or visit the Fens, especially in the winter season, must have given the King but slight hopes of reducing the brave defenders of this natural stronghold by starvation.* Dugdale, also, quoting the register of Ramsey Abley, after expatiating upon its strong insular position, and the beauty of its surroundings, says its waters, especially Ramsey Nere, abound with Eels and 'Pikes of an extraordinary bigness,' 'and although both fishers and fowlers cease neither day nor night to haunt it, yet is there always of fish and fowl no little store.' At a much later period, early in the seven-

* "Liber Eliensis" (ed. Stewart), pp. 23r, 232. 
tecuth century, Drayton, in Song 25 of the 'P'olyollion' (IIolland's Oration), in a most interesting passage enumerates the IBirds found in the Fens; and Fuller* thus writes of the quality and excellence of the Lincolnshire fowl :-

"In the micldle of the eighteenth century, the same state of things oltained in the East Fen, and is graphically described in a most interesting 1)issage, though ton long to quote, in Gough's edition of Camden's 'Britannia.'t The same author, speaking of Crowland, also tells us that, 'their greatest gain is from the fish and wild cluclis that they catch, where are so many, that in August they can drive into a single net three thousand duclis; they call these pools their corn-ficlds; for there is no corn grown within five miles.'

"The population of such a unique country, as might be expected, was sui generis; and the life of a Fen-man, could it be written from a Naturalist's point of view; would, indeed, be interesting; but the material is now, alas, of the scantiest. There is a curious poem extant-for a sight of

* Op. cit. vol. ii. p. 2.

" "Lincolnshire may be termed the Aviary of England, for the IVild-foule therein; remarkable for their,

I. Plenty; so that sometimes, in the month of August, three thousand Mallards, with Birds of that kind, have been caught at one draught, so large and strong their nets ; and the like must be the Reader's belief.

2. Varicty; no man (no not Gesmar himself) being able to give them their proper names, except one had gotton Adam's Nomenclator of Creatures.

3. Deliciousnesse; IVild-foule being more dainty and digestable than Tame of the same kind, as spending their grossie humours with their activity and constant motion in flying.'

$\dagger$ Vol. ii. ( 1806$)$ pp. $3^{80}, 3^{8} \mathrm{r}$. "The East Fen is now drained and cultivated; but there still remains a tract of country, though not in Fenland, but in Norfolk, which greatly resembles the East Fen of past days in that happy admixture of water and dry land, interpersed with reed beds and dwarf marsh trees and shrubs, so acceptable as breeding quarters for Wild-fowl. Though apparently unlinown to the old writers on such matters, the Norfolk Iroads were as rich, if not richer, in marsh and water-breeding birds than any of the localities they love to expratiate upon, and they long remained unchanged, after the more famous resorts were drained and deserted by their former inhahitants. Although we have lost the Godwit, Ruff, Black Tern, Arocet, and Bittern, still, in the present year, eight out of the nine species of Duck which are known to breed in England are still nesting in this cuunty, and seven of these may be found together in one favoured locality of no very considerable extent. Happily they are most rigorously protected; hut I question whether any other district in England of like extent can claim as many species of this family as regular breeders." 
which I am indebted to Mr. J. J. Colman, M.P.-purporting to be the 'Life of a Fen-man ; but, although it gives some interesting glimpses of the Fen-man's mode of life and occupation one hundred years ago, the author utterly fails to avail himself of the fine opportunity which offered of immortalizing himself。 *

"In the introduction, the author thus describes the isolated condition of the dwellers in the Fens:- "The Fen is a vast plain intersected with various natural and artificial rivers, defended with high banks to prevent the overllowing of the high country floods in their passage to the sea. On these banks the inhabitants, for their better security, erect their miscrable dwellings, at a great distance sometimes from each other, and very remote from their parish churches, to which they rarely resort, unless to a wedding, a christening, or a burying. So that they seem to be cut off from the community, and are deprived of almost every advantage of social life. It is a rare thing to meet with a village of twenty houses together, unless in their towns, from which they are many miles distant. They are therefore excluded every opportunity of the very lowest education, and few of them arrive at a higher erudition than to be able to read and write.' The life of hardship and privation endured by this

" "Humble race of men,

Alike amphibious, by kind Nature's hand

Form'd to exist on water or on land,'

is thus described by our Fen-Parson in one of his prose notes:- 'The life of a North American savage is vastly preferable to his. They both live by their gun. The one traverses the woods and mountains in search of his prey, and retires at night to a warm cabin, with plenty of fuel to warm the rigour of the climate; the other in a little skiff, which a puff of wind would overset, paddles about the water till the evening, and comes home wet and cold to his miscrable hut, and lies scarcely dry and warm all night in his bed. The American Indian also bears a near resemblance to our hero; as a fisherman he has his canoe, and ventures upon the shoals in search of fish; he has also his favourite dog to attend him, and hopes that as he is his constant and faithful companion in this life, he will be in another.

" 'But thinks, admitted to that equal sky,

His faithful dog shall bear him company.'

* 'The Inundation; or 'The Life of a Fen-man: A Poem. By a Fen-Parson.' (Lynn: W. Whittingham.) 20 pp. 4to. No date, but published about the year $1771 . "$ 
The Parson's poetic description of the Fen-man's daily life is not quite so oromy as his prose: but it will be secn that a help-meet is here introduced - perhaps the former description applied only to a bachelor :-

" He rises early, and he late takes rest,

And sails intrepid o'er the wat'ry waste;

Waits the return of shot-seal* on the lake,

And listens to the wild-fowl's distant quack,

At dusk steers homeward with a plenteous freight,

The crazy vessel groans beneath the weight.

A tidy house-wife waits his coming home,

Gets dry apparel, and cleans up her room.

Prepares a cheerful fire, brings out her hoard,

And spreads a homely plenty o'er his board.

To vend her fowl the dearest mart she tries,

And with the profit household wants supplies.

The Capital's ev'n feasted with her store,

And London carriers whistle at his door.'

And the cottage, brightened by the presence of a thrifty house-wife, is thus described :-

" His little hut, which by the bank-side stood,

Cover'd with coat of sedge, and walls of mud,

Where each domestic use one room supplies,

His victuals here he dresses, here he lies:

A little lattice to let in the day,

With half-extinguished light and glimm'ring ray.'

In a note to the line, 'Lonclon carriers whistle at his door,' the author inclulges in some remarks upon 'the luxury of the Metropulis, which are curiously characteristic of the times. He says: "There are a set of people

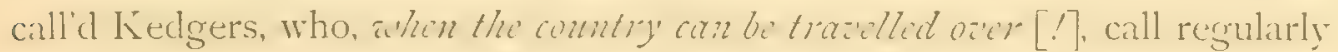
at the Fen-men's houses to buy their fish and fowl at a vast price, and send them up to town, by the butter-boats, or sell them to the higlers that keep) London market. But what is that to the extravagance of a Norwich weaver, who sends a special messenger from thence to Caxton, $†$ which is near one hundred miles, to meet the north country carrier with fresh salmon.' And again: "It is almost incredille to believe, what great advantage the skilful Fen-man makes of his winter shooting in a clowned year, and in the

* "Flight-time."

+ "Caxton is a small market-town in Cambridgeshire, and is situated at the point where the road from Norwich zici Newmarket and Cambridge first strikes the great north road, about twelve miles north of Royston." 
following summer of his fish. By the overflowing of Whittlesea Mere, and other great reservoirs of fish, the whole country is plentifully stocked with them.' After an overflow of Whittlesea Mere, when the waters retired, they were said to have 'folded;' and at that time the dykes and rivers would be found full of fish, which had escaped from the Mere cluring the flood, and afforded ample harvests to the Fen-men. Another very considerable source of profit was the Smelt-fishery. Large quantities of these fish were taken, then as now, when they came up the rivers to spawn, ancl a single share in this fishery was known to amount to fifty pounds.

"Our Fen-Parson refers to the malarious emanations from the sodden Fen, and draws a loathsome picture of the 'Genius' of the place, 'pale Febris,' as 'she shiver'd o'er a cow-dung* smoky fire,' and laments the absence of health, even when plenty smiles the fairest :-

" The moory soil, the wat'ry atmosphere,

With damp, unhealthy moisture fills the air.

Thick, stinking fogs, and noxious vapours fall,

Agues and coughs are epidemical.'

It is probable that malarious fevers would be more prevalent during the drainage of the Fens than when they were still more or less in a state of nature; and the writer has vivid recollections of his sufferingrs as a boy from 'intermittent' fever, which was at that time prevalent at Lynn, it may be in consequence of the cutting of the Eau brink canal, which led the course of the river Ouse direct from St. Germains to the town of Lynn, leaving the old and sinuous course of the river to wharp up. The cut, which was opened in $182 \mathrm{I}$, had been completed twenty years; but as Dr. Macleant has shown, marshes are not, as a rule, dangerous, when abundantly covered with water; and that it is only when the water's level is lowered, and the saturated soil is exposed to the drying influence of a high temperature, and the direct rays of the sun, that the poison is evolved in abundance; the circumstances were, therefore, at that time, most favourable for the dissemination of the malarial germs, not only the freshly-turned soil and margins of the cut being exposed, but also the old bed of the river which took many years to drain and bring into cultivation. This state of things led to a most pernicious abuse of opiates,

* In this treeless country cow-dung was carefully dried and stored for winter fuel.

† "Quain's 'Dictionary of Medicine :' article 'Malaria." 
laudanum being consumed by the Fen-folls, by whom it was at first used as a prophylactic against malarious fever, or as an antidote to the periodic attacks - in quantities altogether astonishing. Happily, with the disappearance of the disease, the abuse of the remedy has gradually ceased; and at the present time, although, doubtless, there are many confirmed elderly laudanum-drinkers in Fen-land, it is a practice which is fast dying out, and will, it is to be hoped, cease with the present generation of elders. Ague was familiarly known as the "Bailiff of Marshland.'

"A very eccentric character, named William Hall - who loved to style himself 'Antiquarian Hall,' 'Will Will-be-So,' or 'Fen Bill Hall'died at Lynn in 1825. Hall was born on June Ist (old style), 1748, at Willow Booth, then a small island 'of but few perches' in extent, in the Lincolnshire Fens, near Heckington Ease, in the parish of South Kyme. He has left behind him some dloggerel verses, now very scarce, entitled 'A Chain of Incidents relating to the state of the Fens from earliest accounts to the present time. Printed by $\mathbb{W}$. G. Whittingham of Lynn in is 12 for the author, and sold by him only. Price one shilling.' This 'sketch of local history ' only reached its third number, and the only copy I have seen is in the library of the British Museum. It is a curious mixture of odds and ends in prose and doggerel verse, but is interesting from the references it contains to the state of the Fens in the author's early days, and the occasional glimpses it reveals of the life led by the 'Fen slodgers' more than one hundred years ago.

"In his 'prefatory salutation' he thus addresses his reader (p. 3) :-

" 'All hail! esteem'd aquatic friend, Since both our aims are for one end;

To tell those that's not seen much water, In days of yore what was the matter;

Announce to th' public we are penmen, By narrating the lives of Fen-men.'

"Of the place of his birth he speaks as follows :-

" ' Kyme God knows,

Where no corn grows,

Nothing but a little hay, And the water comes, And takes it all away. 
Where Ducks by scores travers'd the Fens,

Coots, Didappers, Rails, Water-hens,

Combin'd with eggs, to charge our pot.

Two furlongs circle round the spot. *

Fowl, fish, all kinds the table grac'd,

All caught within the self same space;

As time revolv'd, in season fed,

The surplus found us salt and bread;

Your humble servant, now your penman,

Liv'd thus a simple, full-bred Fen-man.'

"With regard to his imperfect education, he begs the reader's indulgence, the first twenty years of his life having been passed five miles from church or school, amid conversation of the 'lowest, vulgar kind,' with only six months' schooling :-

" 'Pray, sirs, consider, had you been

Bred where whole winters nothing's seen

But naked floods for miles and miles,

Except a boat the eye beguiles;

Or Coots, in clouds, by Buzzards teaz'd.

Your ear with seeming thunder seiz'd

From rais'd decoy, - there Ducks on flight,

By tens of thousands darken light ;

Who liv'd for months on stage of planks,

'Midst Captain Flood's most swelling pranks,

Five miles from any food to have,

Yea often risk'd a watery grave.'

"In a foot-note at page 6 he thus explains the line, 'From rais'd decoy,' \&c. :- 'This was the six hundred Decoy; the pond, about three acres of water, well sheltered and distant from disturbance, became so great an asylum, that I have heard divers decoymen say it was apparently impossible for an egg to be dropped without hitting one. $\dagger$ Our house was a full mile parallel distance; and when they were disturbed, any stranger would suppose it distant thunder. It is the author's intention to devote a part of the work under the life of a low Fon-man, where he will descant more

* "Referring to Willow Booth, the place of his birth, Hall appends the following note : - "Then an island of but few perches. The author was the last person living who was born upon it." "

+ This was the one in South Kyme Fen, hereinafter mentioned under Lincolnshire Decoys. 
largely upon Decoys, having never seen but one rational writer on the subject, and he has manifested that he knows nothing of the theory.' The author, unfortunately, never carried out his intention of writing ' rationally' upon decoying, with a knowledge of the practice added ; and decoys themselves had almost become things of the past before any accurate description of their construction and working was written.

"Such was the early life and training of this eccentric individual. Of his summer occupation, when following his calling, the following quotation from page I I will give some idea :-

"Born in a coy, and bred in a mill,

Taught water to grind, and Ducks for to kill;

Seeing Coots clapper claw, lying flat on their backs, ${ }^{*}$

Standing upright to row, and crowning of jacks;

Laying spring nets for to catch Ruff and Reeve,

Stretched out in a boat with a shade to deceive.

Taking Geese, Ducks, and Coots, with nets upon stakes,

Riding in a calm day for to catch moulted Drakes;

Gathering eggs to the top of one's wish,

Cutting tracks in the flags for decoying of fish.

Seeing Rudds run in shoals 'bout the side of Gill sike,

Being dreadfully venom'd by rolling in slake;

Looking hingles, and sprinks, trammels, hoop-nets, and teamings,

Few persons I think can explain all their meanings.'

"The above is a most interesting catalogue of the numerous out-door occupations of a Fen-man, and of the modes and engines formerly used in fishing and fowling. It is impossible here even to enumerate, much more to describe in detail, the varinus forms of nets and snares employed at the time Hall wrote, or the ingenious resources made use of lom approaching fowl, as well as the multifarous nets and devices for capturing the fish which so abounded. Of his winter occupation I tall says nothing ; but, doubtless, reed-cutting occupied much of his time; his clomestic leese also required

* "This, doubtless, alludes to the defensive attitude assumed by the Coot when fighting or hard pressed. Gill sike, mentioned lower down, is the name of an old drain in the Holland Fen; and slake is, probably, an accumulation of stagnant mud. In a Commission of Sewers, 1616-I7, slake is more than once referred to as a stoppage of the water (W'ells' 'Bedford Level,' vol. ii. p. 47, \&c.). As to the meaning of 'crowning of jacks,' I can only venture a suggestion, that it was mest likely' some method of capturing l'ike, pre balily hy striking them on the head with the "yuant-pulc' unel for propelling the boat, when they lay in shallow water at spawning time." 
his attention, and these, with the Duck decoy, would provide ample employment for the shortened days. During frosty weather, constant attention was required at night, after the decoy had 'risen,' to break and remove the ice, thus keeping the water open as an attraction for the Ducks, without which they would desert the decoy in hard weather. Subsequently Hall set up as a cow-leech, and ended his days as a dealer in second-hand books at Lynn, his 'Antiquarian Library 'being situated near the 'Globe Hotel,' in a street leading from the Tuesday Market-place to Common Staithe Quay."

The Author makes no apology for this dissertation on Fens and Fenmen, as both are so closely connected with the subject of Decoys.

\section{Decoys in zuse.}

Ashby.

Decoy's not in use.

Bourne.

Deeping Fen (5).

Cowbit.

Fleet.

Dowsby.

Aslackby.

Millyard Farm.

Sempringham Fen (3).

South Kyme.

North Kyme.

Timberland.

Nocton Hall.

Friskney (5).
Hagnaby.

Wainfleet St. Mary's (2).

Wrangle (3).

Leake.

Skellingthorpe.

Burton Hall.

South Carlton.

South Kelsey.

Farlsthorpe.

Broughton.

Keadby.

Great Cotes.

Ashby Decoy, $6 \frac{1}{2}$ miles IVNIT. of Brigg, in the parish of Bottesford, $4^{\frac{1}{2}}$ miles SW. of Frodingham Station, on the Grimsby and Doncaster 
branch of the M. S. and L. Railway, and 2 miles from the right bank of the River Trent at Althorpe, to the left of the road from Ashby to Burringham Ferry. Here may be seen the most successful existing Decoy in the kingdom, and the only one now worked in Lincolnshire. It was lately owned by Captain Healy (whose father, Mr. Henry Healy, constructed it), but upon his death in I 868 it was offered for sale, and was purchased by old Mr. Tacey (lately deceased), the father of Mr. George Tacey, who now owns it. The extent of the pool is about 2 acres, and it has four pipes. Captain Healy had an accurate account kept of each day's capture from its first winter in $1833-34$ down to that of $1867-68$, and the results, as arranged in the subjoined table, which was published in the sporting papers at the time the Decoy was offered for sale on the death of its owner, will give some notion of the immense number of fowl annually taken, as well as the proportions in which the various species are found associated together. From this it will be seen that the captures have averaged 2,74 I head of wildfowl per annum, and in the course of five-andthirty years there has not been such a decrease in numbers as from various causes might have been expected. Mr. J. Cordeaux, of Great Cotes, Ulceby, when visiting this Decoy in December, 1882, was informed by Mr. Tacey that a few years ago he had taken 6,32 I Ducks and Teal, and of these 2,300 were captured in 31 days, or in just a month's time. The average take for the last dozen years in the Ashby Decoy has been nearly 3,000 fowl in a season. The largest number of fowl taken at Ashby during recent years at a single drive was in 3 Wild-duck. The same day 248 Ducks were caught in all.

Stonehurst, in his "Hist. and Topog. of the Isle of Axholme, I839," states (pp. 62-70), that a covey of Partridges was once taken in a pipe here.

The Decoy is well kept and managed, as is likely to be the case, for its tenant states it pays him better than the farm attached to it.

Birds taken in the Ashby Decoy from 1833-34 to 1867-68:- See table on following page. 
An Account of Wildfowl killed at the Ashby Decoy from September, 1833, to APRIL, I868.

\begin{tabular}{|c|c|c|c|c|c|c|c|}
\hline & Ducks. & Teal. & Widgeon. & Shoveller. & Pintail. & Gadwall. & Total. \\
\hline I $833-34$ & 1884 & 1232 & IO2 & $\ldots$ & 9 & $\ldots$ & 3227 \\
\hline I $834-35$ & 4287 & 1860 & I 40 & 16 & 54 & $\ldots$ & 6357 \\
\hline I $835-36$ & 959 & 788 & 38 & I 6 & 7 & $\ldots$ & 1808 \\
\hline $1836-37$ & 768 & 326 & 24 & 14 & $\ldots$ & $\ldots$ & I 32 \\
\hline I $837-3^{8}$ & I 5 I I & 509 & 47 & I I & 4 & $\ldots$ & 2082 \\
\hline $1838-39$ & $75^{8}$ & $79 \mathrm{I}$ & $2 \mathrm{I}$ & 2 & 4 & $\ldots$ & 1576 \\
\hline I $839-40$ & 2014 & 2002 & 24 & $2 \mathrm{I}$ & 74 & $\ldots$ & 4205 \\
\hline I $840-4$ I & 2584 & 993 & 126 & I 3 & 8 & $\ldots$ & 3724 \\
\hline I $84 \mathrm{I}-42$ & I 666 & 908 & 28 & 5 & 6 & $\ldots$ & 2613 \\
\hline I $842-43$ & 1094 & 2077 & 49 & 6 & 2 & $\ldots$ & 3228 \\
\hline I $843-44$ & I 004 & $103^{6}$ & 88 & 3 & 3 & $\ldots$ & 2 I 35 \\
\hline I $844-45$ & 1298 & I I $8 \mathrm{I}$ & 65 & I & 2 & I & 2547 \\
\hline I $845-46$ & 1022 & I $32 x$ & 39 & 3 & 5 & I & 2390 \\
\hline I $846-47$ & 1428 & 905 & 43 & 5 & 4 & I & 2486 \\
\hline $1847-48$ & 1212 & 883 & 36 & ... & I & I & 2133 \\
\hline I $848-49$ & I 740 & $197 \mathrm{I}$ & 53 & 9 & 5 & $\ldots$ & 3778 \\
\hline I $849-50$ & I I 45 & 956 & 27 & ... & 2 & I & 2 I 31 \\
\hline $1850-51$ & 380 & $8_{53}$ & 34 & $\ldots$ & 3 & $\ldots$ & 1270 \\
\hline I $851-52$ & 632 & 1003 & 72 & I & 2 & I & I 7 I \\
\hline $1852-53$ & 2682 & 3279 & 67 & 2 & 26 & 3 & 6059 \\
\hline I $853-54$ & 2425 & 1605 & 75 & I & 3 & 2 . & 4 I I I \\
\hline I $854-55$ & I 298 & I $22 \mathrm{I}$ & 89 & 3 & 2 & 3 & 2616 \\
\hline I $855-56$ & 1004 & 781 & 33 & 4 & 4 & $\ldots$ & 1836 \\
\hline I $856-57$ & 763 & 771 & 27 & II & I & 2 & 1575 \\
\hline I $857-58$ & 634 & I 566 & I IO & 24 & I I & 3 & 2348 \\
\hline I $858-59$ & 715 & 1208 & 82 & 4 & 4 & $\ldots$ & 2023 \\
\hline I859-6o & 734 & I 204 & 83 & 7 & I & ... & 2029 \\
\hline I $860-6 I$ & I I 2 I & 2365 & 23 & 34 & 3 & I & 3747 \\
\hline $1861-62$ & 1605 & I I 45 & 54 & II & 6 & I & 2822 \\
\hline I $862-63$ & 843 & $148 \mathrm{I}$ & 25 & 14 & $\bar{I}$ & ... & 2464 \\
\hline I $863-64$ & 2326 & 1842 & 82 & 20 & 6 & $\mathbf{I}$ & 4277 \\
\hline I $864-65$ & 1663 & 1205 & 85 & 5 & I & $\cdots$ & 2959 \\
\hline $1865-66$ & 282 & 637 & 17 & ... & $\ldots$ & $\ldots$ & 936 \\
\hline I $866-67$ & I 89 I & 1502 & 66 & 4 & 12 & $\ldots$ & 3475 \\
\hline $1867-68$ & 1292 & I 16 I & 75 & I 5 & 2 & $\cdots$ & 2545 \\
\hline
\end{tabular}

From this table we find that the Decoy has accounted for nearly I00,000 wildfowl in thirty-five seasons, consisting of-

\begin{tabular}{l|l|l} 
Wild-duck $\cdot \quad 48,664$ & Shoveller . . . . 285
\end{tabular} \begin{tabular}{ll|l} 
Teal . . . 4 4 4 . . . 2768 & Pintail .
\end{tabular} Wigeon . . 2,019 Gadwall . . . 22

Grand Total . 95,836 
The largest number of fowl taken in a single season was in I $\{34-35$, when 6,357 are recorded as captured, since which date over 6,000 fowl have twice been caught in two different seasons.

Beginning in the south of the county, a line drawn from Whittlesey in Cambridgeshire to Sleaford in Lincolnshire intersects numerous ancient and disused Decoys. The first two met with are those of Whittlesey and Borough Fen. The former in Cambridge, and the latter in North Hants, will be found under their respective counties. Crossing, however, from Nort Hants into Lincoln, we at once find a group of six old

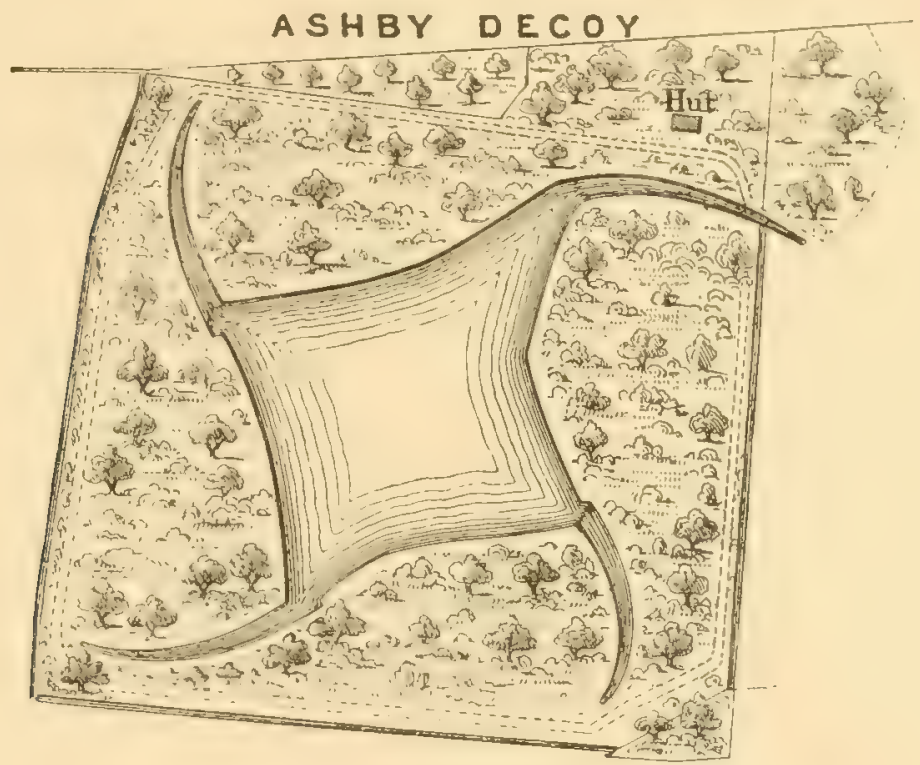

Decoys close together, and all within $6 \frac{1}{2}$ miles E. of Bourne, and just halfway between the latter town and Spalding. They are as follows :-

Bourne Decoy', in Bourne Fen, halfway between Twenty Station (on

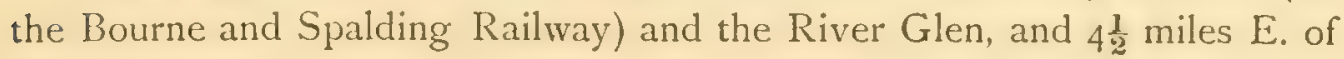
Bourne.

Decping Fen Decoy's, of which there were fwe on the northern edge of Deeping Fen, between Spalding Common and Bourne Fen, and between the River Glen and the North Drove Drain. The four northernmost of these are within a space of a mile long, and are within 6 miles E. of Bourne. 
Cowbit Decoy, in Cowbit Fen, to the east of the latter. The Decoy is a mile $\mathrm{N}$. of Cowbit, and 2 miles $\mathrm{S}$. of Spalding, on the E. side of the River Welland.

Fleet Decoy, in Fleet Fen, E. of the last. The Decoy was situated 6 miles S. of Holbeach, on the verge of the S. bank of the South Holland drain, 3 miles NE. of the hamlet of Whaplode Drove Chapel, as well as 2 miles NNW'. of Sutton St. Edmunds. This Decoy was destroyed by the cutting of the South Holland drain in I 793.

Travelling further north towards Sleaford, we soon get to another group of six old Decoys, all within 3 miles NE. of Dowsby, the most southern of which is the famous Dowsby Decoy.

Dowsby, near Falkingham, 6 miles NE. from Bourne.--It is stated by Daniel in his 'Rural Sports' (Suppl. p. 623), that in one season there were caught in the Decoy here 1,075 dozen and eight wild ducks (12,908 birds), which on an average fetched $7 \mathrm{~s}$. per dozen.

The Decoy has long ceased to be worked.

This Decoy belonged to the Rev. Thomas Foster of Ryhall, grandfather of the present owner, who has kindly supplied the appended copy of an original document, recounting the birds taken in the season $176_{5}-6$, with details of the catches for October and March :-

Wildfowl caught in Dowsbi Decoy from October i, i 765 , to APRIL I, I 766.

13,008 birds, sold to Mrs. Gibbs of Langtoft, at 7 s. a dozen $\begin{gathered}\mathscr{f} \\ 379\end{gathered}$

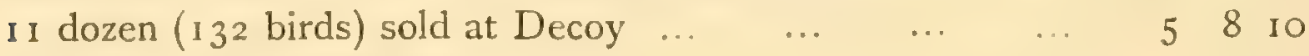
20 couples sold to Mr. Dodd ...

. $\quad \begin{array}{rrr}1 \quad 10 \quad 0 \\ £ 386 \quad 6 \quad 10\end{array}$

Total number of fowl sold, therefore, was $13,180$.

As Teal and Wigeon were counted as is to the dozen, the grand total for the year would represent at least i 8,000 fowl.

In this season $(1765-66)$ there were taken in the Decoy, in the months of October and March, as follows, which is, it need scarce be pointed out, for these months wonderfully good, even for those days of abundance :- 


\begin{tabular}{|c|c|c|c|c|c|c|c|c|c|}
\hline October & I & $\ldots$ & $\ldots$ & $\begin{array}{r}\text { Fowl. } \\
78\end{array}$ & March & 4 & ... & $\ldots$ & $\begin{array}{r}\text { Fowl. } \\
\ldots \quad 152\end{array}$ \\
\hline ", & 8 & $\ldots$ & $\ldots$ & I I 9 & , & 7 & $\ldots$ & $\cdots$ & $\ldots 158$ \\
\hline ," & 12 & $\ldots$ & $\ldots$ & I IO & $"$ & I I & $\cdots$ & $\cdots$ & ... ISO \\
\hline ", & 16 & $\ldots$ & $\cdots$ & I I I & $"$ & I 3 & $\cdots$ & $\cdots$ & $\ldots 218$ \\
\hline " & 19 & .. & ... & I 10 & " & I 8 & $\cdots$ & $\cdots$ & $\ldots 248$ \\
\hline , & 23 & .. & .. & $13 I$ & , & 2 I & $\cdots$ & $\cdots$ & $\ldots 158$ \\
\hline , & 26 & ... & $\cdots$ & IOS & ", & 25 & $\cdots$ & $\cdots$ & ... 240 \\
\hline$"$ & 30 & . & .. & 176 & , & 28 & ... & $\ldots$ & $\cdots \quad 114$ \\
\hline & & & & 943 & & & & & 1,46 \\
\hline
\end{tabular}

The site of the Dowsby Decoy is a level field, and no traces of it remain.

Within a mile NE. of the latter is the Aslackby Decoy. A mile still farther north are fon other pools close together, the most eastern of which is the Millyard Farm Dicoy'; these four Decors all heing close to the N. bank of the Sempringham drain in Sempringham Fen, and within 3 miles E. of Billingborough.

South Kyme Decoy.-Still travelling north, we reach the above in South Kyme lien, close to the $\mathbb{W}$. bank of Holland Dyke, 2 miles SE. of South Kyme, and 6 miles SSII'. of Tattershall. This is the "600 Decoy" alluded to on page I 14 , and which derived its name from a farm called the "6oo," that being the number of acres connected with the latter.

North Kyme Decoy', 3 miles NNW. of the last, 2 miles SSE. of Billinghay, and $4 \%$ miles SII, of Tattershall. This Decoy was placed at the W. corner of Drury Dyke, in North Kyme Fen.

Timberland Decoy, in Timberland Fen, $3 \frac{1}{2}$ miies E. of Timberland, close to the W. bank of the Dales Head Dyke.

Nocton IIoll Decoy. on the estate of the Marquis of Ripon, in Nocton Fen. The Decoy is $2 \frac{1}{2}$ miles SE. of Potter Hanworth, and $S$ miles SE. of Lincoln. The pond is about 2 acres, had five pipes, and is placed in an ash wood of $1+$ acres. Serenty to eighty years agro immense numbers of Duck were taken here, and even now as many as a couple of hundred will collect on the water.

Taking a line eastward to the coast at Wainfleet, we come to a well- 
known district for Decoys, and where, before the East and WVest Fens were drained in the early years of the present century (1809), no less than a dozen flourishing Decoys existed, and of which little trace now remains, save one. This one is the oft-spoken-of Friskney Decoy, and the trustces of the Booth estate at Friskney have recently purchased it in order to preserve it, as far as possible, in its original state, as a memento of past times.

Friskney Ncw Decoy, 4 miles SW. of Wainfleet, in the parish of Friskney, and 3 miles from Wainfleet Railway Station. It was once one of the best in the county, but has not been worked since 1878 .

This Decoy was in full work with six nets up to i855, under John Skelton, who succeeded Henry Skelton (sce page I3). The average take during the seasons previous to this date was 3 to 4 dozen birds a clay, and the best day's work was 300 to 400 fowl. In one year Skelton is once said to have sold $f$ joo worth of birds. But as the land around became cultivated, the Decoy declined, and so two nets were discontinued from I 855 to I860; after the latter date only three nets were used. In I860 John Skelton left the Decoy, and it was then worked by Mr. Crowe, whose best take was 85 ducks in one day, and but I, I00 in one season (I 866 ).

It appears, from White's "Directory," that in I8og an Act was obtained for embanking, enclosing, and draining the marshes around Friskney, which were then generally flooded for six months in the year, and had several extensive Decoys, in which upwards of 30,000 head of Duck, Teal, and Wigeon have been taken in one season, and sent to the London market. All but one of these Decoys (Friskney) have given place to fertile corn-fields.

The pool now being described consisted of an acre and a half, and was surrounded by 14 acres of wood. It had formerly, as stated, six pipes, but latterly only three, and is now no longer in working order; though the outline of the pond is still plainly visible, some of the old hoops and stakes being still to be seen.

This Decoy was the original home of old George Skelton (senior), and it was from here he emigrated to Norfolk, and taught the Norfolk Decoymen how to work and make Decoys of moderate size, in opposition to their previous habit of attaching Decoy pipes to large broads and meres. How well he succeeded is elsewhere shown (Sec I/ intorten. Norfolk, and p. I I.) When the Friskney Marshes were drained at the beginning of the 


\section{PLAN OF DECOY WITH 6 PIPES, SCALE-I2OFT TO AN INCH.}

$100 \quad 50$
$H-1$

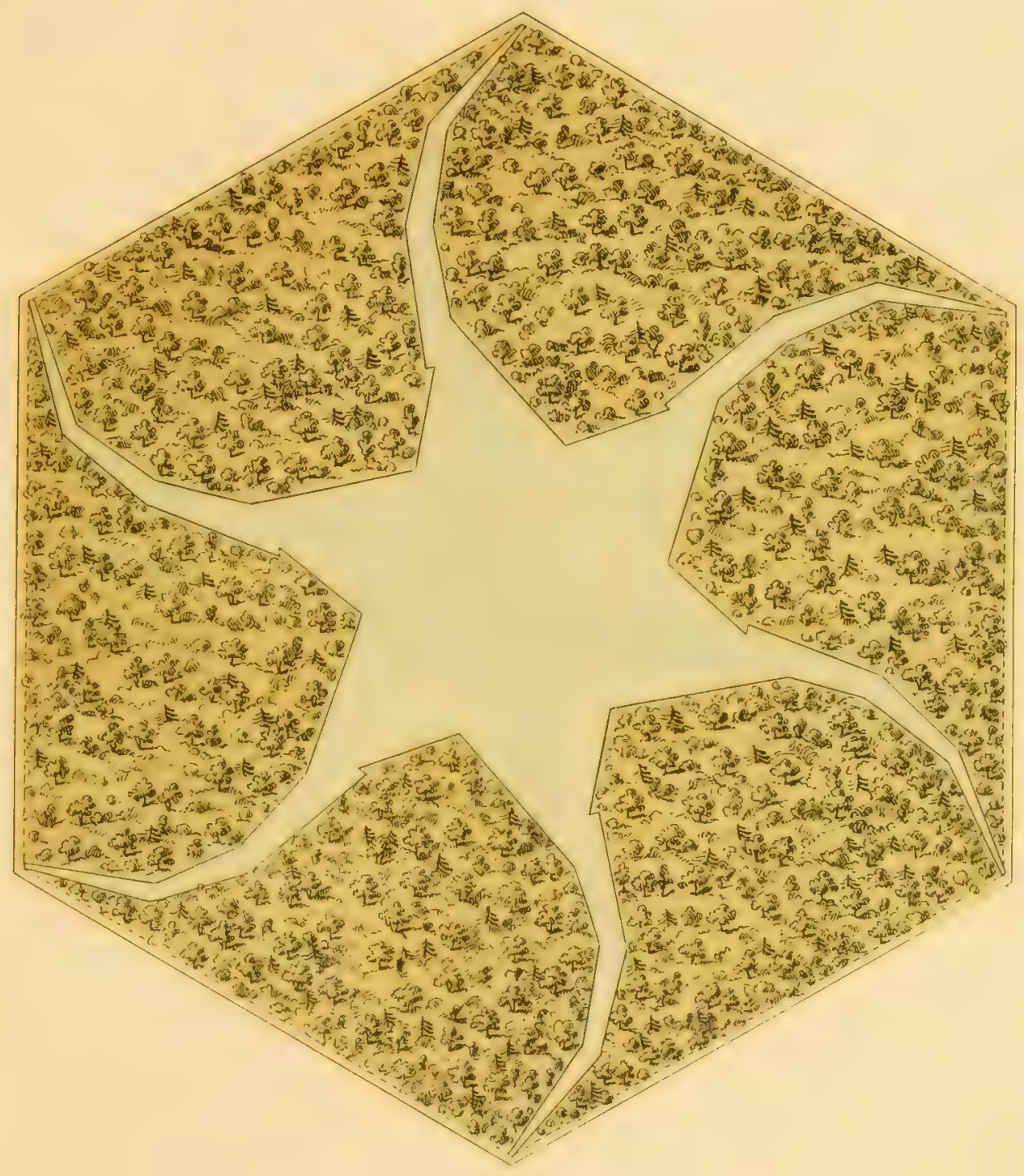

FRISKNEY.

Bluc _ Water

Green Land 

present century, this Decoy, with its fellows in the adjoining parishes, suffered considerably.

Doubtless this fact prompted the removal of the old Decoyman Skelton and his family to Norfolk, as a more suitable county in which to pursue his avocation of catching wildfowl.

When old George Skelton left Friskney in ISO7, his sons William and Henry worked the Decoy till i $S_{45}$. On William, at that date, movin: tc Combe Abbey, Lord Craven's scat in Marwickshire, his son, John Skelton, manarged it for Captain Hopkins, and, as stated, continued to do so till i 860 .

In Oldficld's "History of Wainfleet," I $S 29$, 1) I $S O$, a capital description is griven of the Decoys at Frisliney, and in the acljoining parish of Wainfleet St. Mary's. It runs as follows :-

"Great as are the advantages arising from the enclosure and drainage, they have in some measure been counterbalanced, as it respects the parish of Wainfleet, by the loss sustained by the Decoys, and the almost total failure of the cranberry harvest. Friskney was at one time noted for the number and magnitude of its Decoys, and for the immense number of wildfowl caught in them. London was at that period principally supplied with Duck, Wigeon, and Teal from the Decoys in this neighbourhood.

"In one season, a few winters prior to the enclosure of the Fens ( 1 Sog) ten Decoys, five of which were in the parish of Wainflect, furnished the astonishing number of 31,200 wildfowl for the markets of the Metropolis. Since the enclosure, the number caught has been comparatively small. Only three Decoys remain, two in Friskney (the other Decoy in Friskney was the property of the IVard family), and one in Wainflect St. Mary's, and the Decoymen consider 5,000 birds as a good season."

In this parish, besides the above, there were formerly four Decors within a rery short distance of each other, owned by T. and J. Williams, Richard Skelton, and Thomas Dodds (two), respectively, of which the one above described, and owned by George Sletton, was the must northern.

Hognuby:-.. In this parish there was one Decog, owned by Thomas Dowse.

Wainflect St. Mary's, a parish between Hagnaby and Friskney, in which two I ecoys existed, owned by William Lell and Danicl Matidens. Wrangle, the next parish, and south-west of Friskney, in which 
three Decoys were worked, one by Richard Alford and two by T. and J. Williams respectively. The pool nearest the sea was known as the "shore" or "Old Tom IVilliams's" Decoy, as it was worked for him for many years before he removed to the Lakenheath Decoy in Suffolk, and where he is said to have died at the age of rog.

Lcalic, the parish next to Wrangle on its west side. There was a pool here which was out of use at the end of the last century, and is marked on the drainage maps of that date as "an ancient Decoy."

The Decoys in the four last-named parishes ceased to exist early in the present century.

All the Decoys now described in this county are south of Lincoln. Those to follow are north of that town.

Skcllingthorpe Decoy, 2 miles W. of Lincoln and a mile SSE. of Skellingthorpe, between the catchwater drain and the main clrain. This Decoy was a square pond with four pipes, and the form of it can easily be discerned, though it has not been in use for 40 years.

Burton IIall Decoy.-The residence of Lord Monson, a mile SSW. of South Carlton and 3 miles NIV. of Lincoln, on the E. side of the main and catchwater drains. The owner informs me that the site of the Decoy has been ploughed up, and that no traces of it now remain.

Sonth Carlton Decoy, also on the property of Lord Monson, and of which traces are still to be seen. This pool is on the W. bank of the catchwater and main drains, is a mile IV. of the Burton Hall Decoy, and $3 \frac{1}{2}$ miles NW. of Lincoln.

Neither of these Decoys have been in use since the beginning of the present century.

South Kelscy Decoy, I miles NVW. of South Kelsey, on the southern sicte of Kelsey Carrs, near the N. bank of the Caistor Canal. Long disused.

Farlsthorpe Decoy', 2 miles SE. of Alford, in Farlsthorpe Fen, halfway between Alford and Mumby.

All these old Lincolnshire Decoys were, with a few exceptions, destroyed by the Drainage Acts of 1795,1807 , and I So9, the Skellingthorpe one holding out the longest, being worked till 1840 . One by one their arocation was destroyed, the means of sustenance being taken from them as the fens in their inmost recesses became cultivated. For now 
the very outline of most of these ancient Decoys is gone, and luxuriant grain-fields flourish where previously a wilderness of reeds and stagnant, bird-haunted waters stretched far and near.

Broughton Decoy', 3 miles NNIV. of Glamford Briggs, in Broughton Carrs, on the IV. bank of the W Wear Dyke, near the River Trent. Disused for 45 years, as stated by the old Decoyman who last worked it. and who is now living. Appleby village is $3 \frac{1}{2}$ miles SE. of this pool.

The remains of the Broughton Decoy are plainly visible. It was 2 acres in size, and had six pipes, the whole enclosure being Io acres.

Leadby Decos: $2 \frac{1}{2}$ miles SE. of Crowle, I $\frac{1}{2}$ IVN NW. of Keadby, a village on the left bank of the Trent. The Decoy is situate $\frac{1}{2}$ a mile N. of the Stainforth and Kealby Canal. Little trace of it now remains, as the waste ground on which it was then placed is now drained and cultivated.

Great Cotes Decoy, $2 \frac{1}{2}$ miles WSW. of Grimsby, close to Laceby Beck, a stream which dirides Great from Little Cotes, and near Towns Holtwood Plantation, formerly known as IVyber's. The pool has vanished under cultivation, and has not been in use for 80 years. 


\section{HISTORY OF DECOYS-(continued).}

\section{CHAPTER IX.}

Decoys in the County of Middlesex.

Decoys in use.

None.
Decoys not in use.

St. James's Park.

Decoy in St. James's Park.

Tinougin difficult to realize at the present day, yet formerly a Decoy existed in St. James's Park. It was situated at the west end of the lake, which at that time was straight and formal, and called "The Canal." The Decoy was placed in an island, then known as the Duck Island. That this Decoy was not a trap Decoy, but a Pipe Decoy, as they are now fashioned, there can be no doubt, on taking into consideration the material used in its construction. It was made by Charles II., who was devoted to wildfowl and other birds, and who spent all his spare hours in feeding his ducks and fondling his spaniels, of which latter he had so many about his court that they were in contemporary journals written down a nuisance. Evelyn writes, March 29, I 655: "His Majesty is now finishing the Decoy in the Park."

The following, which I derive from Cunningham's " Handbook of London," vol. ii. p. 434, gives full details of the cost of making this Decoy :-

To Edward Maybanke and Thomas Greene for digging the Decoy, and carrying out the earth and levelling the ground about the said Decoy, £1 28 2S. I I $\frac{1}{2} \mathrm{~d}$.

To Edward Storey, keeper of the King's birds, for wyer and other things used about the Decoy, and for roo baskets for the ducks, $\mathcal{L} S 9$ s.

To $\mathrm{S}^{\mathrm{r}}$. George Waterman for several netts for the Decoy, $£$ I $53 \mathrm{~S}$.

To James Rimes for plants and 400 bolts of reeds for the use of the Decoy, fi 5 I Is. $8 \mathrm{~d}$. 
To Edward Storey for money paid to sundry workmen for setting the rceds and poles round the Decoy and wiring it, $£ 9$ Ios.

To Syclrach Hilcus for ye contriving of the Decoy in St. James Park, E. 30.

For oatmeal, tares, hempseed, and other corn for the bircls and fowle's from September, I660, to June 24, I670, £246 ISs.

To John Scott for carpenters work done in wharfing and making bridges in the Island and borders, and for boards used about the Decoy and other work, $£ 45$ I 5s. 4 d.

(Signed by Charles II.)

There is no doubt that Charles had many thousand waterfowl, both tame and wild, on the Canal in those days, and he doubtless used the Decoy for catching them from time to time, as required for table use, and to reduce their ever-increasing numbers.

It is also quite possible that large numbers of wild duck frequented the Decoy and water, and mingled with the half tame ones, for at that date firearms, in a sporting sense, were few and clumsy, and little used on game or fowl.

The Thames, and the great marshes that bordered its banks, and the outskirts of London as well, would in those days be haunted with wildfowl, and so form a good lead to the Canal and Decoy. Indeed a writer in the "New Critical Review" for I 736 allucles to the Park and water as on one side bcing bounded as by a wilderness and desert, though he says its other side is the height of civilization and beauty.

Le Serre, a French writer, speaking of St. James's Park in I633, says, after describing the public buildings and houses, "These are bounded by a great Park with many walks, all covered by the shade of an infinite number of oaks. . . . . This Park is filled with wild animals."

- In r66r, observant and quaint old Pepys remarks in his Diary, "To walk in St. James' Park, and saw a great variety of fowls I never saw before."

But perhaps the best description of the birds in the Park in those day's is to be found in Evelyn's Diary, March 29, I665. He says, "I went to St. James' Park, where I saw various animals, and examined the throat of $\mathrm{y}^{\circ}$ 'Onocratylus,' or Pelican, a fowle between a Stork and a Swan, a melaincholy waterfowl brought from Astracan by the Russian Amlassador : 
it was diverting to see how he would toss up and turn a flat fish, plaice or flounder, to get it right into its gullet. . . . .

"Here was also a small waterfowl, not bigger than a Morehen, that went almost quite erect like the Penguin of America. It would eat as much fish as its whole body weighed. I never saw so unsatiable a devourer, yet $\mathrm{y}^{\circ}$ body did not appear to swell bigger.

"The Solan Geese here are also great devourers, and are said soon to exhaust all ye fish in a pond.

"Here was a curious sort of poultry, not much exceeding the size of a tame Pigeon ..... a milkwhite Raven, a Stork, which was a rarity at this season, seeing he was loose and could fly loftily. Two Balerian Cranes. . . . The Park was at this time stored with numerous flocks of several sorts of ordinary and extraordinary wildfowl breeding about the Decoy, which for being near so great a city is a singular and diverting thing." *

It appears from this that Charles II. was a very prince of bird fancicrs ; he it was who gave the name to Birdcage IValk, for along its trees were hung cages with birds, whose sale and barter he encouraged. On the ground below, and between the trees, were fixed his own aviaries.

At that date Birdcagre Walk, and the greater part of St. James's Park, especially what was known as the Inward Park, were kept very quiet and select, and there were most stringent regulations in force to prevent damage occurring to the Royal pets. Edward Storey, whose name is mentioned in the Decoy cxpenses, was the King's Bird Keeper, and Storey's Gate, at the south-eastern entrance to the Park, derives its name from his house having stood at that point.

Duck Island (the Decoy had long before disappeared) was abolished at the end of the last century, for Pennant remarks, in I 790 , that under the new improvement it had lately ceased to exist.

* Wild-duck now and then visit, and nest in, the Z. S. Gardens in Regent's Park, and regularly appear, during the winter, on the Long water in Kensington Park, as well as, occasionally, even on the Serpentine lake in Hyde Park! 
Decoys in the County of Monmouth.

\section{Decoys in use.}

None.
Decoy's not in use.

Wilcrick.

Nash.

Nash and Iilcrick, 4 and 5 miles E. from Newport, within 3 miles of the Bristol Channel. On the Caldicott Level, and some distance from any dwelling in these two parishes, there were formerly two Decoys, that at Nash belonging to Miss Mrilcox, that at Wilcrick (or Whitson) belonging to the Misses Rouse of Court-y-Ralla, near Cardiff. They were both owned by the late Mr. Joseph Wilcox, and are believed to have been constructed about So or roo years ago. They have been disused since I 8 \& $\$-49$. Each pool covered about an acre, and they had six pipes apiece. Duck, Teal, and Wigeon were taken, the number varying considerably; but on one occasion 99 were caught in one drive at the Nash pool. The ITilcrick pool is 500 yards S. of Bishton, on the South Wrales Railway, and 3 miles W. of Magor; the Nash pool a mile E. of the former one.

When the Great Western Railway was constructed, and passed within half a mile of these pools, the llecoys became worthless. I am informed that $£ 500$ was paid by the Company in compensation.

\section{Decoys in the County of Montgomeky. \\ Decoys zn ase. \\ Lymore Hall. \\ Decoys not in use. \\ None.}

Lymore Hall, within 200 paces of the mansion, and about lialf a mile from the county town of Montromery, at Lymore Hall, the property of Earl Powis, is a pool of 2 acres, surrounded by plantations, where a Decoy was constructed about the year I802. It has three pipes, two facing the north and one facing the south. Comparatively few fowl, however, are captured, the average "take" every scason for the last ten years, within the present keeper's knowledge, being not more than fifty couple. 


\section{HISTORY OF DECOYS-(continued).}

\section{CHAPTER X.}

\section{Decoys in the County of Norfolk.}

Certainly in former days Norfolk was, like Lincoln and Essex, also the land of Decoys, for there were more of them in this county than in any other in England, excepting the above-named counties.

The shape of the county is nearly elliptical, and it is so surrounded by the sea and by rivers that it may almost be considered an island. In the days when the Decoys were at their best in this county (1808 to I830), a great part of Norfolk consisted of rabbit warrens, fen lands, and sheepwalks, and though these have been greatly reduced in area, they still exist in parts of the county to a large extent.

Possessing such an extensive coast-line, and abounding in numerous sluggish rivers and streams, besides many meres and "broads," Norfolk is especially adapted, both from its outlying position in the North Sea, as well as by reason of its varied extent of marsh and water, to attract aquatic birds, and at the present day a larger number of wildfowl frequent and nest in Norfolk than is the case in any other county in England.

I am greatly indebted to Mr. T. Southwell, F.Z.S., of Norwich, who has very kindly assisted me to most of the particulars I am able to give of the Decoys in this county.

There are five Decoys in use in Norfolk, one of which only, that at IV estwick, is near the coast. The other four, viz., Southacre near Swaffham, Didlington near Brandon, Wretham and Merton near Thetford, are quite inland.

The disused Decoys are placed all over the county, except in its centre.

Commencing in the NW., near Castle Rising, on the shores of the Wash, and travelling round the coast to Yarmouth, we meet fourteen old Decoys, the first of which is the Dersingham one, and the last, or most 
southern, the one at Mautby, the latter being about halfway between the sea-coast and Norwich.

Next, taking a line west from Yarmouth, we come to a Decoy at Besthorpe, near Attleburgh, with none others near it save the one at Wretham, which is in working order.

In the extreme west of the county, and within a dozen miles of Downham Market, there is a group of no less than eight Decoys, two of which, namely; the one at Didlington, and the other at South Acre, are now worked. All these eight Decoys are east of the Great Ouse River, and in the district between the Rivers Nar and Brandon.

\section{Decoy's in ase.}

Westwick.

South Acre.

Wretham.

\section{Decoys not in use.}

Dersingham.

Holkham.

Langham.

Wolterton.

Cawston.

Gunton.

Hemstead.

Waxham.

Winterton.

Hemsby.

Woodbastwick.
Didlington.

Merton.
Ranworth.

Acle.

Mautby.

Besthorpe.

Narford.

Wormegay.

Stow Bardolf.

Hilgay.

Methwold.

Hockwold.

IVestritck-Two miles south from North Walsham, and 6 or 7 miles in a direct line from the nearest sea-coast, at Walcott, is Westwick Decoy, charmingly situated in one of the prettiest and wildest spots in the county. It was constructed by the late Mr. John Berney Petre, about sixty years ago, and has been worked ever since. The extent of water is about half an acre, and there are three pipes. It is on the estate of Mrs. M. L. Petre, of Westwick House, Norwich. 
The late Lieutenant-Colonel Duff, M.P., whose widow, Mrs. Petre, now owns the Westwick estate, kindly furnished Mr. Southwell with extracts from the Decoy-book for seventeen years, from which it appears that the average take during that period was about 400 each season. Since 1872-3 the forvl have been classified, and the number taken since then in six seasons is as follows:-2,362 Duck, 587 Teal, 3 Wigeon, and 3 Pintail ; total 2,955, or about 493 per season. ()f the Teal 320 were killed in one season. In $1876-7$, which was the best year recorded, 76I fowl were taken; in I $877-8$ only 320. Colonel Duff remarked that some years ago from 1,000 to 1,500 was the usual take. In the season of $1884-57$ I 8 Duck and 6 Teal were taken in the Westwick Decoy. A dog is not used, and the fowl are enticed into the pipes by feeding only.

This Decoy, from the nature of the surrounding country and its secluded situation, is little affected by agricultural operations.

South Acr, on the River Nar, $3 \frac{7}{2}$ miles NIV. from Swaffham, and 3 miles from Narford Hall, on the estate of Mr. A. Fountaine, is a Decoy, still worked, which was made in 1843 by George Skelton for the Rev. John Fountaine, and concerning which Mr. Southwell obtained the following particulars from James Plumb, who was Decoyman there for twenty-three years. Plumb states that there was no Decoy-book kept, but the average take each season was about 300 fowl. These were chiefly Duck and Teal; Pintail were rare; IVigeon 3 or 4 yearly; Gadwall a few ; ; and Shovellers seen, but none taken. The largest takes were generally in November; the numbers of both sexes were about equal; Mallards were very seldom taken without Ducks. The pool, upon which this Decoy is made, is about an acre and a half in extent, and has four pipes. It closely resembles in form the Decoy at Didlington.

Wretham, on a piece of water called " Mickle Mere," 30 acres in extent, situated in Wretham Park, about midway between Thetford and Watton, is a Decoy, or rather lake, with ten pipes, which was made some fifty years ago for the late Mr. Wyrley Birch, and has been worked pretty regularly ever since. A Decoy-book has been kept since I868. The largest take in one year during Mr. Birch's superintendence was I,409; the smallest 125. In the latter case, however, the paucity of numbers was accounted for by

* Gadwall now nest, and exist in considerable numbers, on the lake at Narford, as well as on the lakes near Merton. 
the fact that some of the pipes were broken down by a heavy fall of snow. The months in which the best "takes" occur are very uncertain. It is said that a good year for acorns is a bad year for ducks, as the birds are continually leaving the Decoy to go into the plantations after the acorns, and will not settle down on the water. Very few "half birds" (i.e., Wigeon and Teal) are killed, sometimes not twenty in a season, although there are often many thousands on the water. In the season of $1883^{-4}$, as I am informed by the present owner of Wretham, Mr. Morris, 1,6.40 ducks were taken; the most ever captured in one season since Mr. Morris has owned the IVretham estate being 1,760, the average take annually being $\mathrm{I}, 000$ fowl.

On the Ordnance Map, at East Wretham, near Stone Bridge on the "Peddars Way," is a plantation marked "New Decoy." This, however, is only a name. There has never been a Decoy there.

Among the peculiar birds and animals caught in the IVretham Decoy by the present Decoyman, who has, I may note, worked it for nearly fifty years uninterruptedly, are a Woodcock, Snipe, Moorhen, Hawk, Blackbird, Thrush, Pheasant, Partridge, Wildgroose, Owl, Kingfisher, a Rabbit, and a -Pig!

The IWretham Decoy has more pipes in use (ten) than any other Decoy now worked, one being a left-handed pipe.

Didlington, about 9 miles NIV. of the last-mentioned Decoy, is another, which was constructed by the Rev. J. Fountaine in 1865 for its present owner, Mr. IV. Tyssen-Amherst, M.P., of Didlington Park. It is situated in a wood of 10 acres, about 500 yards from the mansion. It is just an acre in extent, and has four pipes. The fowl taken are chiefly Duck and Teal, with a few IVigeon; the average number caught annually being 500. In one season I,000 were caught, and many more than are now taken might be easily captured were it not that the Decoy is only worked for pleasure and sport, and not for profit.

In the shooting season the wood in which the Decoy is situated is usually shot once or twice. On one of these occasions when the Author was present, after first decoying some Ducks, 200 to 300 Phicasants were killed in the covert surrounding the Decoy, yet two days afterwards there were as many Ducks as before in the Decoy; showing that shooting round a Decoy occasionally will not damage it. 
An amusing incident occurred the first time this Decoy was worked. Mr. Fountaine, who constructed it, was anxious that its reputation should be at once established by making a successful catch in it the first time it was tried. In the presence of the seventh Duke of Leeds, he proceeded to work the Decoy. In one pipe were some eighty Duck he had lured well inside ; all were driven up the pipe successfully, but, alas! the tunnel net had been omitted at the pipe's end, and every bird dashed through and away

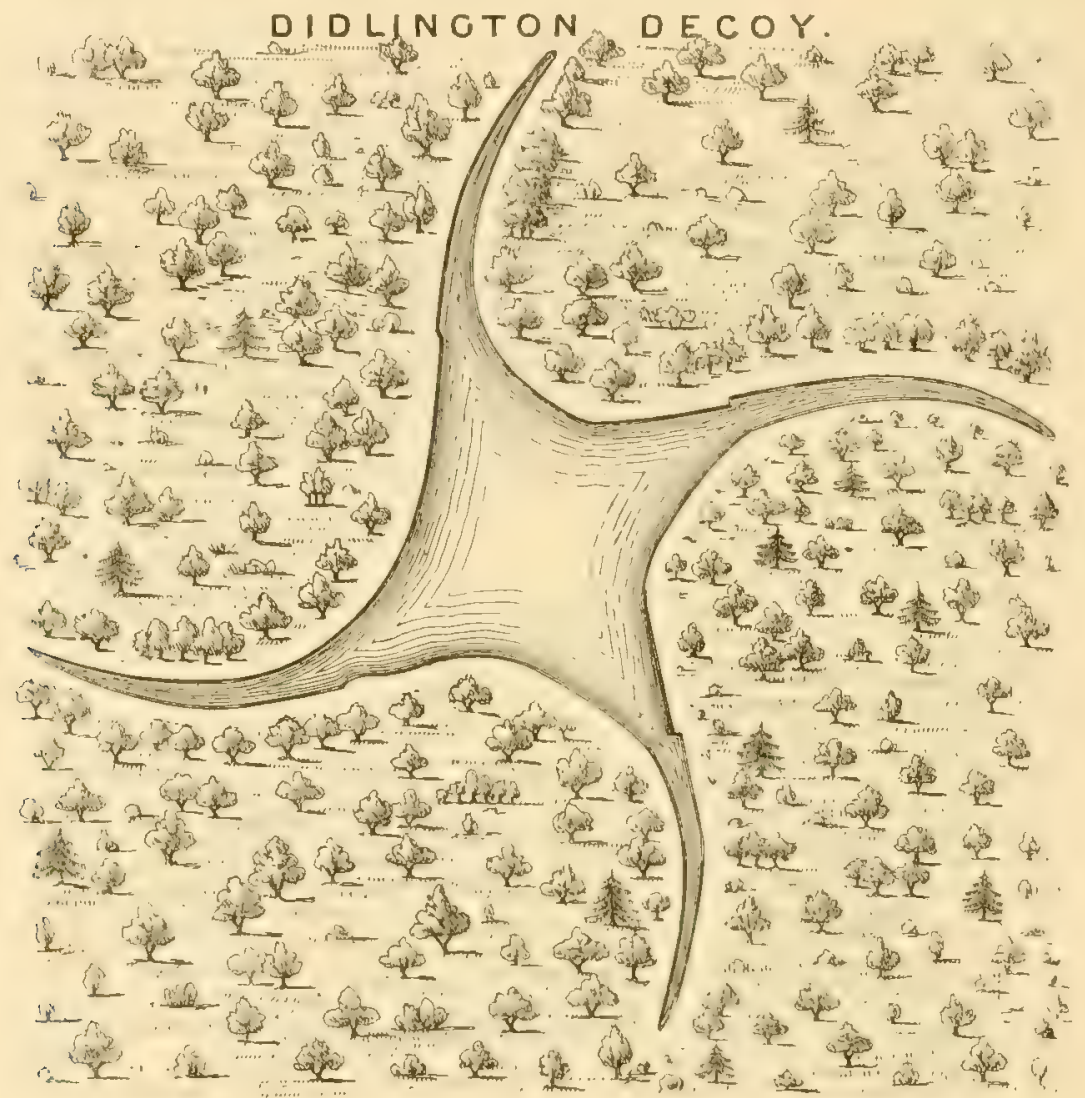

to freedom. Quoth the Duke, "Well clone, Mr. Fountaine! now, can you put them through again, may I ask ?"

The Duke was particularly interested in Decoys, Mr. Fountaine having at that date just assisted in planning one for him at Hornby Castle; so that this accident, though amusing to him, was a great disappointment to Mr. Fountaine. 
The Decoy is maintained in superb order by Mr. Tyssen-Amherst, MI.P., who takes no little pride in its possession,- - both as an object of curiosity as well as an ornamental feature in connection with his fine sporting estate of Didlington - an estate which, I may safely say, is celebrated, both for the immense number of game it shelters as well as for the great variety of wildfowl its fens and rivers afford. There is at Didlington, in the immediate vicinity both of the Hall and the Decoy, a fine mere of 60 acres - a magnificent harbour, to attract wildfowl to the neighbourhood- and from which it is but a short flight for them into the Decoy hard by.

One of the Decoy pipes is actually in view of the windows of the mansion, and though the Decoy is within 300 to 400 paces of a school, gas-works, and a large farm and garden, still its success is so well ensured that $I, 000$ Ducks may often be seen resting in its seclusion.

The Mcrton Dicoy consists of a pipe attached to the eastern extremity of Thompson Mere. This large piece of water, covering 60 acres, is situated 2 miles south of Merton Hall, the latter being $2 \frac{1}{2}$ miles from Watton.

The Decoy pipe was constructed for Lord Walsingham by G. Skelton (1886), and is likely to be successful, for the Merton estate, besides being one of the most fimous in England for its abundance of game of all kinds, stands well-nigh unrivalled as the haunt of wildfowl, both rare and common. So numerous are these birds on the meres of Lord Walsingham's property, that the owner thereof has many times shot to his own gun in a single day from 80 to 100 wild ducks of various species.

Dersingham, 5 miles NNE. from Castle Rising, not far from the shores of the Irash. - About is is a I)ecoy was constructed at this place by. George Skelton the younger, who died here. The pool was about an acre and a quarter in extent and had five pipes. No Decoy-book was kept, but Skelton's brother-in-law, who worked the Decoy with him, stated, that the arerage number of fowl captured every winter was from 1,30 to 200 dozen Mild Duck, Teal, ITigeon, Gadwall and Pintail. Skelton was succeecled by a man named Sharp, from Hilgay, and a new cottage was built for him : but it is said that he was not successful. Owing to alterations in drainage, 
and drying up of the creek on which it stood, the Decoy ceased to answer, and about 1870 was dismantled.

Holkham, 3 miles from Wells, the princely seat of the Earl of Leicester. -On the marshes at Holkham, half a mile north of the church, traces may still be seen of an old Decoy and its pipes. It has not been worked since the commencement of the present century, and no one now living can give any information about it. Its position is shown on a map of Norfolk by Faden, published in I 797. The lake in the park at Holkham is resorted to by immense numbers of wildfowl every winter, many of which remain to breed. In $1884-5$ it was calculated that as many as 10,000 Wigeon passed between its sheltered surface and the adjacent coast every dusk and dawn, the reason being that a vessel laden with corn was wrecked on the sandbanks off Holkham. Such a vast store of grain being scattered on the shore and its flats, the fowl assembled in multitudes from all along the coast to feast on it by night, and so the majority passed the day resting in the scclusion of Holkham Lake, safe from persecution by the gunners.

Langham.--Mr. Southwell states that there was a Decoy at Langham, $3^{\frac{1}{2}}$ miles SW. of Cley, constructed for the late Captain Marryat, R.N. (the well-known author.) After his death, in 1854 , the property was purchased by Mr. S. F. Rippingall, and the Decoy dismantled.

The site of the Decoy is now a field, with a small stream running through it ; plantation, lake, and Decoy all gone. The Rev. E. W. Dowell, who had often seen this Decoy worked, says the proportion of fowl taken was about Wigeon 3, Mallard 2, Teal I.

Il oltcrton, $4 \frac{1}{2}$ miles NNIV. from Aylsham.-Mr. Southwell states, in his paper on Norfolk Decoys, that at the south-west corner of Wolterton Park there is a wood called the Decoy Plantation, and in it the remains of what was once a Decoy, but he was unable to learn anything with regard to it, except that it had certainly not been worked for more than fifty years.

Caruston, $3 \frac{1}{2}$ miles NE. of Reepham.-At the commencement of the present century there was a Decoy in the Bluestone Hall plantation at Cawston, but it was demolished by the grandfather of the present owner of the property, Captain Bulwer, when he headed the pond and enlarged the water. No one now living is able to give any information respecting it. Gunton Park, 5 miles NIV. of North Walsham.-About the year i 80.3 
or I Sof the sccond Lord Sufficld had a Decoy constructed at Gunton, on a mere of 30 acres. It had three pipes, but has long been dismantled. Ilempstcat (near the sea-coast), 9 miles SE. of North W'alsham, and 2 miles SE. from Holt. - Until the year I 845 there was a very productive Decoy belonging to the Gumey family at Hempsteacl, within a fur miles of the sea. It was for many years worked by Richard Skelton, son of George Skelton of IVinterton, who was very successiful, sometimes taking as many as 300 or 400 fowl at one drive.

The Decoyman who succeeded him continued Decoying until i 845 , when, being detected in carrying on an illicit still, hidden in the Decoy wood, by means of which he converted the I'heasants' barley into whisky for his own use, he was summarily dismissed, and the Decoy having fallen out of repair was never afterwards worked.

As no Decoy-book was kept, it is not possible to give any particulars concerning the fowl captured, but the number is known to have been very large.

Truham. - Twelve miles ESE. from North IValsham, and some $\hat{j}$ to $t$ miles S. of the last-named, was placed the Waxham Decoy, in a large marsh near the sea-coast. This is the I ecoy supposed to have been made by Sir William Woodhouse in the reign of James I., who, according to Spelman, was the first person to introduce properly planned Decoy's into East Anglia.

The marsh is now drained, and the site of the pool planted with usiers.

Winterton.-This Decoy, situate a mile N. of East Somerton, $2 \frac{1}{4}$ miles NE. of Martham, and close to the sea, was constructed by old George Skelton, who continued to work it up to the time of his keath in January, I840, when he was succeeded by his son Henry. It has been described by Lubbock in his "Ifauna of Norfolk" (2nd ed. p. I 3. ), in the Appendix to which, at 1). 221, Mr. Southwell has added several interesting particulars from Lubbock's MSS.

It was originally made for Mr. Huntingdon, from whom it passed to the late Mr. Joseph Hume, M.P., whose son some years since dispesed of the property to Captain Bird, since which time it has not leen worked; the proprietor, as in the case of the Mautby and Ranworth Decoys, preferring duck-shooting to Decoying.

The Winterton Decoy was held famous among its fellows as the one 
constructed by old George Skelton, when he first migrated to Norfolk from the Friskney Decoy in Lincolnshire. The Winterton Decoy was much derided by the Norfolk Decoymen on account of its small size (2 acres), compared to the extensive broads then used as Decoys by them.

A derision, however, soon turned to wonder and envy on its becoming known that "Old Sliclton" had succeeded in catching in his "two-acre puddle," as it was termed, I, roo Teal in a week.

Hemsby, I $\frac{1}{2}$ miles SW. of Hemsby, and at the northern end of Ormsby Broad, may be seen the remains of an old Decoy, with 5 pipes, long disused. It belonged to a Mr. Waters, whose son informed Mr. Southwell that it was worked by his father, and that large catches were often made, but that it had not been used since the commencement of the present century.

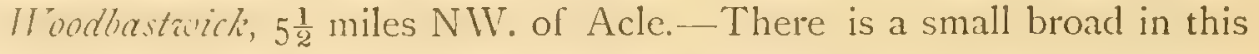
parish, on the River Bure, known as the "Decoy Pond," which evidently derived its name from the Decoy which formerly existed there, the remains of the pipes being still visible. From inquiries, however, made on the spot, it would appear that it has not been used since the beginning of the present century.

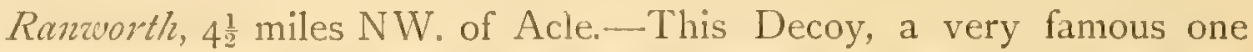
years agro, was attached to the NIV. cnd of Ranworth Broad, and was last worked by its late proprietor, Mr. John Kerrison, about 1869. No regular account was kept of the results, but from some memoranda in possession of the owner's family (which Mr. Southwell was allowed to see) it appears that the annual take was from 900 to $\mathrm{I}, \mathrm{O}$ oo fowl, of which by far the largest number were common wild ducks. The actual figures for the season ISif $4-5$ were: Duck 877 , Teal 70 , Wigeon 8 , Shovellers 3, Pintail I, Tufted Duck I and Goosander I ; total 96 I.

The Decoyman, formerly in Mr. Kerrison's service, informed Mr. Southwell that when the American pond weed, Anacharis alsinastrum, abounded in the district, the ducks evinced such partiality for it, that he had great difficulty in enticing then up the pipes. Of those pipes there were ten, the broad containing some 60 acres of water. It was at the Ranworth Decoy that the late Rer. Richard Lubbock made the practical observations which enabled him to write the interesting chapter on this subject in his "Fauna of Norfolk,"-perhaps the first really reliable account of a Decoy, 
based on actual experience, which had up to that time been published. The date of its construction is unknown.

Acle, 1 I miles E. from Norwich, on the property of Lord Calthorpe at Acle.-A Decoy was worlecl here nearly fifty years a so by a man named Johnson. It is said to have had three pipes, traces of which are still visible, though much overgrown.

Mautby, 2 $\frac{1}{2}$ miles W. of East Caistor, between West Caistor and Runham.- It is uncertain when this Decoy ceased to be worlect. Mr. Fellowes of Shotesham Park, the owner of it, possesses a letter written by George Skelton, dated IVinterton, March $1 S_{33}$, offering to hire it, from which letter it appears that at that date it was out of repair. The offer, however, was declined, Mr. Fellowes preferring the shooting, and the Decoy has never been worked since. The pond is still the resort of large numbers of wildfowl, and the place is kept perfectly quiet, the pipes and the posts of the screens remaining. It was a rery perfect Decoy in its day; of small size, with + pipes, and was cespecially successful in luring the fowl off Breydon Water, where in those days they abounded.

Its position is $1 \frac{1}{2}$ miles on the north bank of the River Bure, to the right of a line drawn from Thrigby to Runham, on the sea-coast.

Besthorpe.-On what is still known as the Decoy Common, in the parish of Besthorpe, I $\frac{1}{4}$ mile from Attleboroush, there was formerly a Decoy, which is believed to have been abandoned about the time of the enclosure of the common in ISI5. An old man, eighty-five years of age, who had resided in the neighbourhood all his life, stated in $1 S$ F $S$ to a correspondent of Mr. Southwell's, that the common was formerly usually under water, and that the ducks used to resort to it up to the clate of its enclosure. He could give no information, however, as to the working of the Decoy.

Norford Hall.-The Rev. J. Fountaine, previous to his constructing the Decoy at South Acre, made two pipes on the large lake in $1 \& 43$, near Narford Hall, and for a few years worked them successfully, as he in one season obtained 1,000 fowl. But his brother, who then owned Narford Hall, being fond of shooting, and not being disposed to grive the lake such absolute quict as the Decoy necessitated, these two pipes were aluandoned in favour of the ncw Decoy, not far distant, on a separate poul at South Acre, near the vicarage of its owner, as already described. 
Womegay.-While resident at Dersingham about i818, George Skelton for a short time worked a Decoy near Wrormegay, $7^{\frac{1}{2}}$ miles NNE. of Downham Narket, and close to the N. bank of the River Nar. The pool was only an acre in extent, and had four pipes. Mr. Southwell was informed by an old inhabitant of the neighbourhood that this Decoy was last used in $1 \delta_{3} \&$, but that about sixty years ago (I $S_{1} S$ ) it was worked by John Balls, who had some very successful seasons, and made several hundred pounds in a few years. The last year it was used, being much out of repair, it was said the amount received was only $£ 20$.

Stow Bardolph, 2 miles NNE. of Downham Market, in the Stow Bardolph Fen, are the remains of a Decoy which has not been used for the last sixty jears. It was the property of Sir Thomas Hare, and well situated to attract wildfowl.

Hitgery, in the parish of Ililgay, 5 miles S.SE. from Downham Market, on the Woodhall Estate, and $1 \frac{1}{2}$ miles NE. of Southery, was an old Decoy known as the Woodhall Decoy, which thirty years ago was owned by a Mr. Wilson. As it was not found to answer, owing to the flooding of the fen, it was given up about $\mathrm{I} 860$, and the traces of it are now obliterated. It was situated on land now the property of Mr. Stocks. Mr. H. M. Upcher states that for about fifteen years the brothers William and George Skelton worked this Decoy, and that at Methwold, next mentioned.

Methwold.-On a tract of land called "The Severals," in the parish of Methwold, $4 \frac{1}{2}$ miles SSE. of Stoke Ferry, I $\frac{1}{2}$ miles E. of Southery, and $?$ a mile from the Decoy at Hilgay, last described, stood another, which was built in 1806 by William Skelton, who with his brother George worked this and the Hilgay Decoy for fifteen years, when the fens became so flooded the two pools could no longer be kept up at a profit. They then remained unused till is $\$ 4$, when Mr. IVilson hired the land of the Duchy of Lancaster and repaired the pipes. A man who worked this Decoy informed Mr. Upcher that he caught a great many fowl, chicfly Duck, Wigeon, and Teal. He could not tell the exact number "driven up at once," but was certain that three to four dozen had been taken "at one drive." Wilson died in $1 \$ 56$, and his widow kept on the Decoy with old T. Williams (se' Wrangle and Lakenheath) as a Decoyman. She gave it up to her brother, Mr. Harwin, in 1862. Williams continued to act as Decoyman till 1870 , when one night he fell into a fen ditch and 
was drowned (his age being reputed at over roo years). I Harwin informed Mr. Upcher that he had some good seasons. On one occasion, when a thaw set in, the fowl coming in hungry from the sea-coast, Williams drove up 75 wild ducks at once, the most he ever saw taken at one time. He had seen from 50 to 60 taken many times. After the death of Williams, Harwin managed the Decoy himself for two years. His fortune, however, in decoying was not so good as formerly. The duck-catching, he considered, was nice amuscment, but working the Decoy was very trying in frosty weather.

This Decoy was abandoned in 1872 , and has not since been used.

Hockivold, s miles W. of Brandon, between Brandon and Littleport.There was formerly a Decoy in Reclmore Fen in the parish of Hockwold, ? a mile from the south bank of the Brandon River, on the verge of the county, and which used to be worked by one Burgess, but about i $S_{3} s$ it was given up in consequence of its being too near the Lakenheath Decoy in Suffolk for both to be worked with profit. 


\section{HISTORY OF DECOYS-(contimed).}

\section{CHAPTER XI.}

\section{Decoys in the County of Northampton.}

THis county is frequented by wildfowl, in any number, only in its NE. extremity, near which portion it is bordered by Lincolnshire and Huntingdonshire, and more or less encompassed by the sluggish rivers $N$ ine and II clland. In former times, when the great meres of Whittlesey and Ramsey, and the Fens of Crowland, Decping, Stilton, Holme, and Farcett were uncultivated, wildfowl frequented the low-lying lands that horder the None and Itclland in Northamptonshire in large numbers. This arca is, however, restricted to the extreme $\mathrm{NE}$. point of the county, and reaches from Oundle to Wansford and thence to Crowland. Between Crowland and Peterborough exists the only fen in the county, that known as Borough Fen, and here is placed an old and well-known Decoy. The only other Decoy in Northamptonshire is Lord Lilford's, at Aldwinckle, on the Nene near Oundle.

Decoys in use.

Aldwinckle.

Borough Fen.
Decoys out of ase.

None.

Alda'incklc, near Lilford Hall, Oundle, $3 \frac{3}{4}$ miles NE. of Thrapstone. A Decoy was constructed here last year $(1885)$ by $T$. Gilbert Skelton for Lord Lilford. It is triangular in form, and has three pipes, one at each corner, and is a very perfect example of a Duck Decoy, as no expense or trouble has been spared in its construction.

The Decoy being situated in the valley of the River Nene, is likely to succeed, as fowl frequent and pass over this valley in large numbers, and also rest on their migration in it, especially when the river floods, as it sometimes does extensively. Lord Lilford tells me that he has seen as 
many as from 1,000 to 2,000 of the aquatic species on his low lands, when the water is out along the course of the Nene, and that he has obtained almost every kind of duck here, including Gadwall.

Borong/h Fcn, 6 miles N. of Peterborough, between Peakirk and Crowland, and 2 miles NE. of the former town, near the S. bank of the River Welland.-There is a fine Decoy here, in good working order, with eight pipes, rented by Mr. John B. Williams, who informs me that it has been in the occupation of his family for over 200 years, and that he has been at great expense in repairing and improving it, but unfortunately he has kept no record of the annual captures made, which were formerly very large.

There is no doubt that this Decoy is one of the oldest established in England. Mr. Williams states that when searching documents at the Bedford Level Office in Ely, he came upon an application, in one of the Minute Books, dated I 670 , made by the Earl of Lincoln, requesting from the Drainage Commissioners permission to pierce the embankment of the River Welland to lead a ditch to his Decoy to supply it with water. This Decoy, and the estate round it, originally belonged to the Earl of Lincoln; it then came into the posession of Lord Eardley, then Sir Culling Eardley Smith, Bart., and it now belongs to Mrs. F. S. Culling Hanbury, of Bedwell Park, Herts, the daughter and heiress of the late Sir Culling Eardley, Bart.

The Decoy lies between the Rivers Nene and ITelland, in the extreme NE. corner of Northamptonshire.

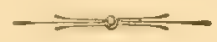

\section{Decoys in the County of Nottingham.}

Though Nottinghamshire is one of the most central, as well as cultivated counties of England, it possesses three Decoys.

These are, however, of peculiar structure, being trap or carce Decoys. The fowl, instead of being fed or enticed up pipes, and then driven, as is the usual custom, are treated quite a different way, as will be seen on perusing the account of the Decoys that pertain to the county. Nottinghamshire boasts some very large lakes, such as those at Clumber, the 
Duke of Newcastle's; II'clbeck, the Duke of Portland's; Thoresby', Earl Manvers'; Park Hall, Captain T. Hall's; and Neastcad, Mr. W. F. Webb's, all the resort and resting-places of large numbers of wildfowl.

Besides these, the River Trent winds through the entire length of the county.

I consider that Nottinghamshire contains, at most times, more wildfowl than any other English county that is without a sea-coast. Nevertheless, the Decoys therein are of a rude and primitive lescription, and are copied from the curious, and doubtless origrinal, one of the county, that at Haughton.

\section{Decoys in use. \\ Haughton. \\ Park Hall. \\ Ossington.}

Decoy's not in use.

Woolaton.

Hanghton Dccoy, I mile north of WValesby, 4 miles ESE. from Clumber, 6 miles SWV. of Retford, and 4 miles NW. of Tuxford.

This Decoy, on the property of the Duke of Newcastle, is doubtiess of considerable antiquity, though the date of its construction is unknown. It is placed in the centre of a wood of 30 acres, and consists of a pool of $S$ acres. It has two pipes, with wooden hoops, covered with wire netting. The fowl, instead of being taken in tunnel nets at the end of the pipes, as in other Decoys, are captured by lowering a trap-door at the entrance to the pipes, after they have entered them for food placed therein. They are left undisturbed in the trap till evening, when the rest of the fowl having flown away to feed, they are then killed. The trap-doors are raised and lowered by means of wires running over pulleys from the Decoy huts. The pipes are 35 yards in length, is fect wide across the entrance, and I f feet high. The water in the pipes is not more than 6 inches deep. Ducks, Teal, and Wigeon are captured here, the number taken annually varying from 300 to 400 . The greatest number ever captured at one time was 30. An accurate Decoy book is kept by the Decoyman, which, on my visit to Haughton, I inspected.

From which it appears that $47 \mathrm{~S}$ Wild Duck and 9 Teal were taken in the season ( $1884,-5)$. 
As many as 500 Wild Duck are sometimes to be seen resting on the surface of the Haughton Decoy in the winter.

The passing of the Ground Game Act is said to have materially interfered with the working of this I)ecoy, as the constant trespass by tenants on the adjoining lands disturbs the solitude of the place and alarms the fowl.

A family of Decoymen named Thard have been at Haughton for generations in connection with this Decoy. The Decoy was originally on the estate of the Earl of Clare, who died in the sixteenth century, and whose daughter married the fifth Earl of Lincoln, ancestor of the present owner of the property. The ancient fish ponds and other appurtenances of the I ecoy evince the great care and expense that has been bestowed on it and its surroundings in bygone days.

This Decoy is, as far as can be ascertained, the oldest trap Decoy in our islands, and it is from this that those at Park Hall, Ossington, and Hardaick were copied. (Sece Harditick for plan and dimensions of a trap) Decoy, page. 7 I.)

Park Hall, 2 miles N. of Mansfield.

There is a trap Decoy on the lake at Park Hall, the residence of Capt. F. Hall. A channel about So feet long, cut through an island in the lake, is arched over with wire netting, and has a falling door at each end, with a division in the centre. The ducks are feel for some time, and when there are a sufficient number in the pipe, the doors are lowered by a wire from the Decoyman's hut. They are left undisturbed in this trap until the other fowl on the pool have left in the evening to feed, when the keeper enters with a landing-net, and, after securing all the captives, resets the trap. (See Hardruick, page 71.)

Ossington Hall, $4 \frac{1}{2}$ miles SSE. of Tuxford, on the estate of Lady Ossington.

About five-and-twenty years ago a trap Decoy was constructed here on the plan of the one at Haughton, just described. It is, however, much smaller in size, being only 24 feet long, and 8 feet high.

The keeper approaches the Decoy by a sunken path surrounded by thick evergreens, and when on peering through these he perceives a sufficient number of fowl in the cage, the trap-door is sently lowered from a distance ly a system of pulleys and wire, inch by inch, until they are all 
enclosed. This is done without in the least alarming the other fowl on the water, and the captives are left until after flight time, when the keeper returns, puts off in a small punt, enters the cage, and wrings their necks. The reatest number of fowl ever taken at one time was 17 , the average number taken annually being about 60; but the Decoy is only used to supply the house, and no regular account is kept. (See Hardaick, page 7..) IVoolaton Hall, 3 miles IV. of Nottingham, and the residence of Lord Middleton.

In the grounds at Woolaton is a lake of 23 acres, with a small island at its northern extremity. On the island was formerly placed a small cage, for entrapping ducks, similar to those at Hardwick, Park Hall, Haughton, and Ossington. Its age is unknown, it is out of repair, and has long since ceased to be used.

Near the lake, on its west side, and about the year I825, a wellplanned three-pipe Decoy was constructed, which consisted of an acre of water.

It was last worked in 1845 , but being so near Nottingham, and in such a populated district, the talies were small, and not exceeding for many seasons 100 fowl, it was finally dismantled.

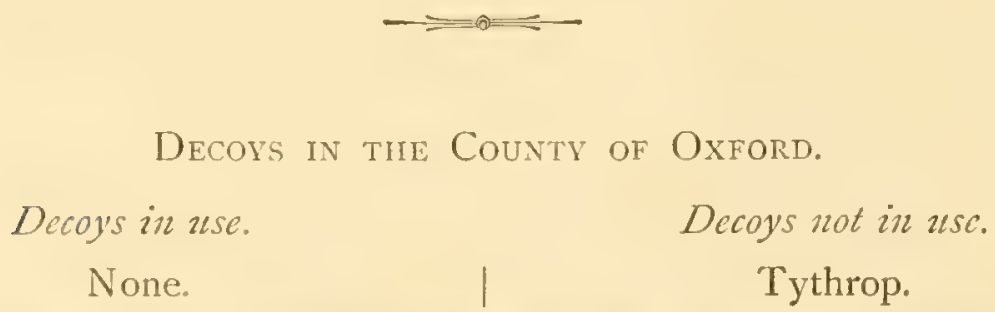

Tythrop Decoy. - Tythrop, though in Oxfordshire, is a liberty of the parish of Kingsey, Bucks, and is 2 miles NE. of Thame. Tythrop House, which is situated $\frac{3}{4}$ of a mile from the Decoy, was the seat of James Herbert, sixth son of the Earl of Pembroke, who was Chamberlain to Charles I., and from him it has passed by devise and descent to the present owner, P. J. D. Wykeham, Esq.

This Decoy is probably a verey ancient one, but it cannot be ascertained up to what period it was worked. There is no one in Kingsey or in the adjoining parish of Haddenham who has ever heard of its being used. 
On an Estate Map drawn in the year 1763 it is shown as "The Moor or Decoy," and the adjoining meadow is called "The Moor Meadow."

On an Estate Map drawn in 1820 it is called "The Decoy."

No pipes are shown on either map.

It would appear, from an inspection of the pond itself, that there are the traces of three pipes, one at the lower, and two at the upper end of the pond.

The brook that divides Tythrop from Haddenham is an ancient mill-stream, and is some feet above the level of the pond, which is supplied by it with water through a floodsate, and the water passes away from the pond by an artificial watercourse.

Oxfordshire is not rich in county histories, and the histories at the Bodleian offer no information as to this Decoy.

Lipscombe, in his "History of Bucks," does not mention it, though he deals with Kingsey. The following coinciclence, however, may be noted, viz., that James Herbert was seized of Tythrop and of the Manor of Kingsey in right of his wife, sole daughter and heiress of Sir Robert Spiller and Elizabeth his wife, who was the widow of Sir John Lynham, Knt, of Boarstall, and, if not the Lady Dynham who was living at Boarstall in 1650 , was alive at the same time.

It is at least possible she might, remembering the Decoy at Boarstall, have induced her husband to construct one at Tythrop.

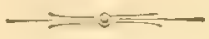

Decoys in the County of Pembroke.

Decoys in use.

Orielton.
Decoys not in nse.

None.

Orietton, $2 \frac{1}{2}$ miles SIT. of Pcmbroke. -This Decoy (a very yood one) is the property of Lientenant-Coloncl Saurin of Orielton, in the county of Pembroke, South W'ales, who kindly supplies the following most interesting details :-It is situated on a lake of 15 acres, within the park, the carriage drive running within 200 yards of two of the tunnel nets. The 
lake lies east and west, is over a quarter of a mile long, and of an average breadth of 150 yards, a stream running through it.

The pipes are four in number.

No. $\mathrm{r}$ is situated on the north sicle of the lake, No. 2 at the north-east corner, No. 3 at the east-south east corner, and No. 4 at the south side of the lake.

No pipes could be placed at the west end, as the lake terminates there in a high embankment. This is a disadvantage, as the prevailing wind during the season is westerly. The pipes average 12 feet in height, the smallest hoop being, as usual, 2 feet. The average width at the mouth is I 8 feet. Nos. 2 and 3 are 70 yards long; No. I about 60 yards; and No. 4 40 yards. The last might advantageously be lengthened, but the nature of the ground is an obstacle.

The lake is artificial, and was made in the year $1 \$ 20$, but though great numbers of wildfowl frequented it, no attempt was made to form a Decoy till the year $\mathrm{I} 868$, when a pipe was constructed on the northern shore of the lake; but owing to its faulty position, and its being overshadowed by trees, was shortly afterwards dismantled, and the pipe called No. 2 was made in $1 S 7$; it having been found to answer, No. 3 was added in $1 S_{73}$.

Next year the pipe No. $\mathrm{J}$ was opened, and this was followed in 1876 by the pipe called No. 4. These four pipes have been in constant working order ever since.

No authentic record is extant of the number and description of fowl taken before the year I $\$ 77$, but since that date a careful account has been kept, from which the enclosed is an extract:-

The largest number taken at one time was i zo Teal, on January I I, 1879.

The greatest number taken in one day was 202, of which the 130 above mentioned formed part; the remainder being made up by I4 Duck, I 8 Wigeon, and 40 Teal. The birds on this occasion all fed in.

As will be seen from the accompanying extract, the majority of fowl taken are Wigeon, which on this coast are excellent for table. Duck and Teal come next in order, the preponderance varying in different seasons according to wind and weather.

In addition to the Pintail and Shoveller Ducks mentioned in the list, I Sheldrake, I Bernacle Goose, I Pochard, and 2 Gadwall have been taken. 
The term "various" includes Swans, Pheasants, Snipe, Waterhens, Baldcoots and 2 Divers.

A curious incident occurred on December 6, is $\$$. . As the Decoyman was entering No. I pipe to feed the tame Ducks, a Heron pursued by a Peregrine clashed into the pipe. The man at once showed on them, ran them into the tunnel net, and took them both.

The means employed for catching are the $\log$ and fecting, a number of tame ducks being kept on the lake. The dog is of most use at the beginning of the season.

As the Decoy was worked by the proprietor principally for his own amusement, the number of birds taken varied with the amount of time he was able to devote to Decoying.

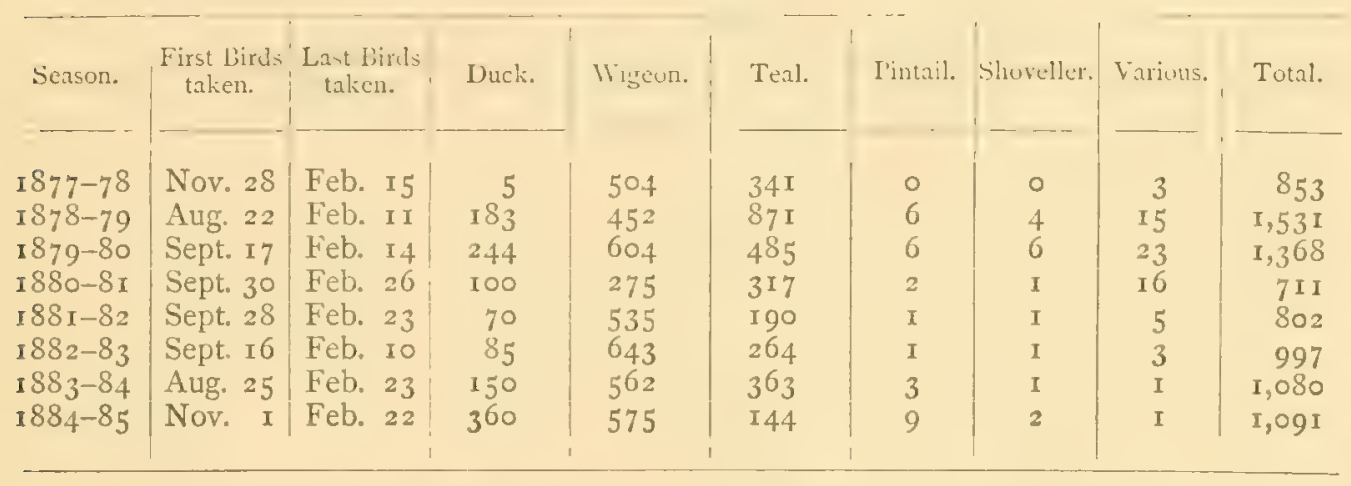

The first pipe at this Decoy was constructed by a gamekeeper named Sharpe, from Norfolk. Two others were made by George and T. Gilbert Skelton, and one of the IVilliamses from Suffolk made the last. The Decoy is situated within a short distance of the south shore of Milford Haven, a large extent of water and ooze much frequented by wildfowl. 
Decoys in the County of Shropsinke.

Decoy's in use.

Oakley Park.

Sundorne Castle.
Decoys not in use.

Aston Hall.

Oakley Park, Bromfield, 3 miles IVNIV. from Ludlow.-The Decoy here is the property of Lord IVindsor, and of some antiquity, being marked in a map of 1796 . It covers an area of about five-and-twenty acres, and has four pipes. Originally there were but two pipes, but in 1834 two others were added by the late Hon. Robert Clive.

The present Decoyman, who has been at Oakley about ten years, states, that the average number of ducks taken annually is from I IO to I 20. His father was Decoyman before him for more than 30 years, and he says they used to talie many more in the first years that his father was there, but owing to some large pool on another property above the Decoy being done away with, they did not get so many birds afterwards.

Sundome Castle, 5 miles NE. of Shrewsbury.-There is a Decoy here on the property of the Rev. J. D. Corbett. It consists of 3 pipes, attached to a lake of 30 acres, and was constructed some 100 years ago by John Corbett, the famous fox-hunter. The Decoy is 500 yards from the Castle. The takes are not large, as the Decoy is only used to supply the table of its owner.

Aston Hall.-There are the remains of a four-pipe Decoy here on the estate of Colonel Richard Lloyd of Aston Hall, Oswestry.

The pool is 3 miles from Aston Hall, and 2 from Whittington. It is placed in an angle between the River Perry and the Ellesmere Canal, on part of a large tract of marsh land known as Baggy (or Boggy) Moor, and through which the River Perry flows. The Decoy is a quarter of a mile distant from both the canal and the river. Its age is about 200 years, but it has not been in use for the last So. It was made by Thomas Lloyd, Esq., of Aston, who died in 1692.

The pool consists of I acre, 2 roods, 6 perches.

There are no records of its successes.

In the Aston pedigree the following note occurs on the page which records the death of Thomas Lloyd, the constructor of the Decoy:- 
"Mr. Thomas Lloyd made a Decoy on the moor for taking wildfowl, and Mr. Mytton, of Halston, huilt a forge close by on the opposite sicle of the River Perry, for the purpose of disturbing the duclis for shooting at them, for which a bill in Chancery was afterwards preferred against Mr. Mytton by Mr. Lloyd." *⿻丷木

In Davies' "History of Whittington Castle," printed about i Soo, the following very curious lines, quoted from an epitaph, occur :-

\section{"ANDREW WILLIAMS. \\ "Born A.D. i692. Died April is, i 776. \\ "Aged 84 years.}

". () which time he lived uncler the Aston family as Decoyman 60 years.

"Here lies the Decoyman who lived like an otter, Dividing his time betwixt land and water;

His hide he oft soaked in the waters of Perry, $\dagger$ Whilst Aston old beer his spirits kept cherry. Amphibious his life, Death was puzzled to say How to dust to reduce such well-moistened clay;

So Death turned Decoyman and 'coyed him to land, Where he fixed his abode till quite dried to the hand;

He then found him fitting for crumbling to dust, And here he lies mouldering as you and I nust."

* Mr. Lloyd won the lawsuit from Mr. Mytton (ancestor of the famous Jack Mytton), and both parties rode up to London to give their evidence.

* The name of the river close by the Decoy. 


\section{HISTORY OF DECOYS-(continued).}

\section{CHAP'TER XII.}

\section{Decoys in the County of Somerset.}

MANy years ago Somerset was a famous county for wildfowl, and must have almost rivalled Lincoln, Norfolk, and Essex in this respect.

In these days of reclamation and cultivation Somerset is fairly well stocked with fowl, such as Ducks and Teal; much more so, in fact, than any other English counties save those on the eastern coast.

Somerset has an extensive seaboard of between 50 and 60 miles, reaching from the border of Gloucester to that of Devon. This frontage of water consists of the Bristol Channel, which abounds in suitable places to attract and collect wildfowl. Hence many of such birds still find their way to inland parts of the county - to spots that tempt them to rest and feed without disturbance.

The immense tract of wild land that can be seen NWT. of Glastonbury by any one ascending the Tor, and which extends from that eminence to the sea-coast, as well as on the western side of the Polden Hills, being especially haunted by the Duck species. At the beginning of the century this flat was still partially uncultivated and subject in winter to frequent floods that almost gave it the appearance of a sea. It consisted of 15 square miles of marsh and wet reed-grown meadows. The corners of the square might be taken as II clls, Lamsport, Uflitl, and Lilstock, and it extended across the county from near the foot of the MIculip Hills to near the Quantock Range.

Midway the Polden Hills rise from the level country. To the N. and $\mathrm{NE}$. of these is the Brue Level, a swampy plain between the Rivers Brate and Axe. To the NW., W. and SW. of the Polden Hills the sluggish River Parrot flows through the large area of low land known as King's Sedgemoor (15,000 acres), so named from the Battle of Seclyemoor, which was fought in and around this, as it then was, morass. These lands lie so 
low that formerly, during exceptionally high tides, the sea frequently broke into them over the sea-walls and laid many thousand acres under water, and in many parts they are still liable to be flooded by freshwaters during the winter. Though there were other considerable tracts of marsh lands in this county, such as Kenn Moor, near Clevedon, NE. of the River $Y c 0$, it was, and indeed is, those previously named that are most haunted by wildfowl, and about which the Decoys of Somerset are placeel.

\section{Decoys in the County of Somerset.}

\section{Decoys in use.}

Sharpham Park.

Shapwick.

King's Sedgemoor (3).

Decoys not in use.

Meare.

Compton Dundon.

Aller.

Godney.

Westbury.
Stoke.

Nyland.

Cheddar Water.

Kenn Moor.

Sharpham Park, 2 miles SII. of Glastonbury; formerly attached to the Abbey of Glastonbury. The Decoy is situated between Glastonbury and Walton.

It is now part of the estate of Lord Kilcoursie, and is at present let to $\mathrm{Mr}$. G. Porter, the tenant of the farm.

This Decoy is the most ancient in the county, and all the other Decoys in Somerset closely resemble it in shape and size, and were without doubt copied from it. For a plan of it, see plan lacing page 9.3, Berkeley Decoy.

It is placed in what was formerly the Deer Park of the Abbot of Glastonbury, and had-or for that matter may have now, if by necessity enforced-a faculty, giving extensive rights of stopping trespass, and enforcing quiet in its neighbourhood should occasion demand. In the vicinity of the Decoy are the remains of the Fish House and Stews, that, togrether with the wildfowl obtained in the neighbourhood, supplied the refectory of the Monks of Glastonbury and the table of its Albot. 
It unfortunately cannot be proved that this Decoy existed in times when the Abbey of Glastonbury flourished, as it is not mentioned in the contemporaneous records that speak of the Fish Houses, Eel and Fish Stews-the Deer, Swans, Herons, and Wildfowl of Sharpham and Meare. The fact that the Decoy is in the Abbot's Park now, of course does not prove it existed therein in the days of the Abbey, though local tradition asserts positively that it did. This pool, once a very lucrative one, is exactly similar to those at Berkeley Castle, the latter having been copied from it.

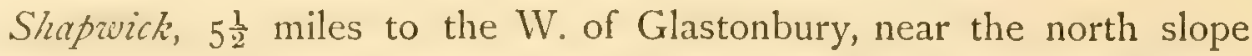
of the Polden Hills, and not far from Sedgemoor, on Shapwick Heath, is a Decoy, which is still occasionally worked, belonging to $\mathrm{Mr}$. G. Warry, of Shapwick House, Bridgewater. In consequence, however, of shooting being carried on near the pool, the fowl are too much disturbed, and do not resort there in any number; so that the working of it cannot be called successful, and is, indeed, but occasional. This Decoy was made by William Chancellor in $1 S_{5}$, and after his death it was never properly supervised.

It has four pipes, and resembles the Decoy at Sharpham as well as those near it at Sedgemoor.

King's Sedisemoor, 4 miles SW. of Glastonbury, and close to the south slope of the Polden Hills, within a mile and a half of Walton, and between that village and Compton Dundon, are three Decoys.

These pools are but a quarter of a mile from one another, and are situated on the vast swampy plain of King's Sedgemoor, before described. They are on the estate of the Marquis of Bath, and from IS68 to I $\$ 82$ were rented, with the adjoining shooting, by Admiral V. Hickley of Taunton. On their late occupier giving them up, I took them for a season, but they proved unsuccessful, and they are now in the possession of a local farmer. The pools are only 30 to 40 yards square, each pool having four pipes, one to every corner. The pipes are very short and narrow, being but 45 yards in length on their curve, and only io feet wide at their entrances.

The pools have no landing-places, and as Decoys are of the most primitive description. It is the custom here to entice the fowl down wind into the pipes, and the Decoymen will not venture near an up-wind pipe, 
however thick the birds may be gathered round its mouth, and consequently does not capture nearly as many fowl as if the Decoy was properly worked in the usual way. The real fact is these pools are so very small that even with burning turf it is hazardous to go to their windward side or approach the up-wind pipes. 'The pipes being so tiny, they are but narrow ditches, and are besides too closely surrounded by trees and brushwood.

The Sedgemoor Decoys are all three exactly the same in shape as, and were originally planned from, the ancient pool at Sharpham Park (sce plan facing page 93), as were most of, if not all the other Decoys in the county of Somerset. The Sedgemoor Decoys are nearly in line with one another, and appear as clumps of trees on the plain.

The east-or as it is called, from a farm near it, the Ivythorn Decoypool, that is the one farthest from Bridgewater and nearest Compton Dundon, has proved the most successful one of the three: the west pool has never done well. The east pool was made in I $25_{2}$, the others shortly after, all three by Joseph Everdell who is now living (18S6) at Walton village near the Decoys. He is still hale and hearty, though some eighty years of age. In his younger days he blew off one of his hands with a fowling piece that burst in use, and the arm that suffered is adorned with a bright steel hook. Old Joe, as he is locally called, is a fine specimen of a stout, though weather-beaten Decoyman, and the manner in which he can still rush behind the screens, drive the birds, and hook them out of the tunnel net and twist their necks, is astonishing, to say the least, as I can testify from experience.

Admiral Hickley, who during his occupation of the Sedgemoor Decoys kept a careful record of their doings, has kindly supplied me with the following facts in regard to them :-

"From I 868 to $18 S_{2}$, the combined average total resulting from the three Decoys was 1,200 fowl, chiefly Mallard and Teal. The best season was $186 \$-69$, when near 3,000 birds were caught. The worst I874-75, when only I 57 were taken. In $1881-82,2,000$ fowl were accounted for."

The Admiral remarks:

"Undoubtedly my best years were those with most variations from frost to coarse southerly weather; the more changeable, and I may say generally detestable, the better." 
Mcare Decoy, 4 miles NW. of Glastonbury.-In the low-lying lands near Meare, through which runs the River Brue, is the site of the ancicnt lake of Meare, thus described by Leland in 1538 , and on the borders of which the Decoy of this name was situated.

"The Meare," says Leland, "is at high waters in winter a 4 miles in cumpace, and where it is lest, a two miles and an half, and most communely 3 miles. This lak or mere is a grood mile yn length, and at the ende of it toward west, it cummith again in alicum, and groing about a mile, it brekith into 2 armes whereof the one goith to Highebridge, the other to Rookesbridge, and so the armes goith asundre to the sea by crekes."

From this description it would appear that originally the pool at Meare was so wide that it would cover the present site of the Meare Decoy, which is just within one mile $\mathrm{N}$. of the eastern end of the village of Meare. The ground to the north of the village is rather steep, so that the margin of the Meare would have been within a quarter of a mile (perhaps within a furlong in most parts) of the road through the village.

This mere was partially drained in monastic times; but subsequently, from neglect of the channels cut for that purpose, it again reached its original dimensions, and the neigbourhood became swampy. Under these circumstances no Decoy could well have existed there at that period, and its construction must have taken place subsequently to the last drainage of the moor, for which an Act of Parliament was obtained in ISOI; though the works reclamation do not appear to have been executed until i So7.

As the Meare Decoy is not mentioned by Collinson in his " History of Somersetshire" (I79I), this rather points to its construction after the completion of the drainage in the early part of the present century, or simultaneously with it. At the same time it should be noted that the neighbouring Brent Marsh, in which are situated the Decoys of Cheddar, Nyland and Stoke, all mentioned by Collinson, was drained under an Act of Parliament passed in I O2. All these lowlands of Somersetshire, were, until well drained, liable to frequent floods, being several feet below the level of the high water springtides.

In a description of the manor of Glastonbury, including the site of the above mentioned Decoys, given by John de Glaston, sometime after 1335, no mention, as may be expected, is made of any Decoys.

"The Meare Pool was NIV. of Godney, between Lower Godney and 
i. and Bordenweare (in which was an Eelery), Lichelake, and Cockswere. The latter was rented in I 5 I 6 by John Gyblat, at twenty shillings a year. There was also another pool called Jameswere rented at $\mathrm{I} 3 \mathrm{~s}$. $4 \mathrm{~d}$. in the time of Henry VII., but which was in the hands of the Abbot in the time of Henry VIII. In these pools swans were kept, and they were frequented by Herons, Geese, Ducks and other wildfowl."

In the survey of the temporalities of the Abbey of Glastonbury after its dissolution (1553) the mere is noticed as follows :-

"There ys apperteynyng vnto the sayde manor one fysshing called the Mere, which ys in circuite fyve miles and one myle and a halfe brode.'

"Also there ys a gaine of Swannes apperteynyng vnto the same water whiche were allwayes belonging vnto the sayde atteynted monasterye of Glastonburye, and vewed upon the surrey to nombre of xl couple. Also there were vewed at this present survey certeyne heronsewes, which have alwayes used to brede there to the numbre of iiij."

Meare Decoy is now the property of Mr. Austin of The Abbey, Glastonbury, who worked it for some years, but not successfully, owing to its proximity to game coverts and the consequent disturbance from shooting. It is now disused.

At Compton Dundon, 5 miles S. of Glastonbury, is an old Decoy pool which has been long disused, but can still be traced. It is situated I $\frac{1}{2}$ miles north of Somerton, near the River Cary, and close to the boundary of Somerton parish. It is on the estate of the Earl of Ilchester, in whose possession the land has been for 200 years.

The churchwarden of Somerton informs me that it must have been at one time of consiclerable importance, as it appears from an old deed in his possession, with a copy of which he has kindly favoured me, that in 1769 it was let to John Witch for seven years, at a yearly rental of $£ 30$, with some strict covenants as to its being kept in repair, and the usual number of Decoy ducks, about three score couple, were to be maintained. It was also provided that the Earl of Ilchester, the owner, was to be "at all times during the said term accommodated with such fowl as he shall require for his own consumption at the price of one shilling a couple for

* John De Glaston, Hist., ii. p. $3^{16 .}$ 
small (Teal and Wigreon), and one shilling and fourpence a couple for large fowl (Wild-Duck), or the usual price paid, whenever the same shall be sent for."

In this covenant the Decoy is alluded to as an ancient one.

Aller.-A mile W. of Langport, north of the River Parrot, from which it is distant a quarter of a mile, and south of King's Sedgemoor, there was formerly a Decoy, on land known as Aller MIoor, then the property of Sir Alexander Hood. It had originally six pipes, subsequently reduced to four, and the pool was between one and two acres in extent. It was given up about 20 years ago in consequence of the continued decrease of fowl owing to the cultivation of waste land in the neighbourhood, and its proximity to the railway, from Yeovil to Durston. The trees and brushwood have been cleared away, and the ground is now open like the rest of the surrounding moor, the pond alone remaining, and that reduced in size.

At one time this Decoy was carefully looked after, and was very productive. The widow of a former lessee, now aged 86, states that she well remembers her husband getting sometimes 20 dozen fowl in a day, and that "hagglers" used to come from all parts and sometimes paid $£_{20}$, for what they carried off. Another old resident in the parish recollects as a boy seeing the Decoy covered with wildfowl "like the dressing spread over a field." He had seen cartloads carried away, and passing to or from the Decoy could often see I, ooo Ducks over his head. The present rector of Aller, the Rev. J. G. Nicholson, who kindly favoured me with this information, adds that he remembers seeing the Dccoy in I 858 , when it was still worked, but its yield had then greatly declined. It is now numbered with things of the past.

Godncy.- On a farm in the hamlet of Godney, 3.12 miles NIV. of Glastonbury, in the parish of that name, and belonging to Mr. Sherston of Evercreech, is a field on Godney Moor which is known as "The Old Decoy." Tradition points to the former existence here of a Decoy, of which nothing but the name remains: and, in reply to my inquiries, Mr. Sherston was unable to supply any information concerning it.

Westbury Decoy, I $\frac{1}{2}$ miles W. of Westbury, on the $\mathrm{N}$. bank of the Axe.-This Decoy is placed within 400 paces of the Stoke Decoy, on its SE. side in the direction of Wells. The two pools of Westbury and Stoke being so close together, are alluded to as one Decoy, by Collinson ("Hist. 
Somerset," iii. p. 417, I791) who writes-"Westbury is pleasantly situated under the southern ridge of the Mendips, 4 miles from $1 \mathrm{~T}^{*} \mathrm{ells}$, and on the road thence to Axbridge.

"The lands are mostly pasture. The River Axe divides this parish from Wookey and Wedmore. Here is a large Decoy pool."

Stoke Decoy, three-quarters of a mile SW. of Stoke Rodney, and 5 miles WNW. from Wells, situated on the N. bank of the River Axe. Probably not constructed until after $1 \mathrm{SO}$, in which year an Act was passed for the drainage of the extensive marshes that bordered the river, and which previously used to be under water nearly all the winter, rendering the working of a Decoy impracticable. However, after the Decoy was made, a subsequent and more complete system of drainage destroyed it.

Little remains now of this Decoy, or the last one described, save their outline and the Decoymen's cottages.

Nyland Decoy, one mile and a quarter IV. of Draycot, on a tributary of the River Axe, is thus referred to by Collinson ("Hist. Somerset," iii. p. 606, I79r). "Nyland Hill, rising abruptly out of the valley, has a picturesque appearance. Near it is a very large Decoy pool, in which a great number of Wild-duck, Teal, Wigeon, Sca-pheasants (Pintail), and other fowl are captured."

This Decoy has long been disused, but distinct traces of its formation are now left. It was close to the SIV. slope of Nyland Hill, and the Decoyman's cottage is still standing.

Cheddar II atcr, I $\frac{1}{2}$ miles SW. of Cheddar, and $1 \frac{1}{2}$ miles S. of Axbridge, on the north bank of the Axe, there was formerly a Decoy, where the stream called Cheddar Water joins the former river. It has long ceased to be worked, and its outline can now scarce be traced.

These last four Decoys all lie within $1 \frac{1}{4}$ miles $S$. of the railway from Wells to Axbridge.

Kcmn Moor, 2 miles SE. of Clevedon.--In the parish of Kenn, and about $2 \frac{1}{2}$ miles NNE. of Yatton, is a farm known as "The Decoy Pool Farm," whereon, many years ago, a Decoy existed in the low meadows bordering the stream which flows from Tickenham to Clevedon, these meadows being often flooded during the winter months. The I)ecoy; however, has long been abandoned, not having been worked since ISzO, 
as a few years previously (I \& 3 ), an Act was passed for the enclosure of waste lands in this part of the county, which destroyed its avocation.

Phelps ("Hist. Somerset," vol. i. p. 49), writing at the beginning of this century, thus alludes to the Decoy:-

"The country is flat and marshy, and there is a large moor called Ken Moor, adjoining to that of Nailscu, in which is a Decoy pond, these levels being frequented by great numbers of Aquatic fowl."

\section{Decoys in the County of Stafford.}

Decoys in use.

None.
Decoys not in use.

Chillington.

Chillington, near Wolverhampton, the property of Mr. Walter T. C. Giffard, consists of two pipes attached to a large lake of 100 acres. It was constructed by Mr. W. Giffard, the uncle of the present proprietor, in the year $1 \$_{25}$, and was regularly worked up to ISS3-4; but now, owing to the amount of repair necessary, is at present discontinued.

The best season here realized Soo fowl; but Mr. Giffard informs the Author, the takes have not of late years approached to near that figure. 


\section{HISTORY OF DECOYS-(contimed $)$.}

\section{CHAPTER XIII. \\ Decoys in the County of Suffolk.}

'Tuis county, at the beginning of the present century, was well stored with wildfowl. Thourh its chief extent consisted of well-cultivated land, still it had immense tracts of waste and marsh, that occupied nearly all the county at its NIV. corner, and which extencled from Newmarlet, on the borders of Cambricleshire, to the confines of Norfolk, near Thetford and Brandon; in the vicinity of which latter town was Lakenheath fien and its Decoy. This uncultivated portion compriserl, as stated by Mr. Young in his agricultural survey (Isot), no less than ioc;000 acres. There was also a considerable amount of low land and marsh that bordered the extensive estuaries of the Alde, Deben and Orwell rivers, and which chicfly lay between Woodbridge, Orford, and Saxmundham.

In this district we find several Decoys existed, the majority of which still remain and do fairly well.

Though Suffolk does not contain the broads and rivers of Norfolk, nevertheless, the estuaries of the rivers mentioned, as well as that of the Stour on its southern houndary, are so large, and penetrate so far inland, that IVildfowl are always somewhat numerous in its SE. portion. To the NE. extremity of the county, is Fritton Lake with its I)ecoys, and to the $\mathrm{NW}$. the fens of Brandon, Lakenheath, and Mildenhall still exist, though of course much reduced in area within the past 50 years.

\section{Decoy's in zese.}

I ken

Chillesford

Orwell Park

Nacton (2)

Fritton (2)

Decoys not in use.

Lakenheath

Benacre

Flixton

Friston

Worlingham

Brantham

Campsey Ash 
IK'?, 5 miles SSE. of Saxmundham, on the Sudbourne Hall Estate, and 7 miles E. of Wickham Market, formerly belonging to Sir Richard Wallace, Bart, and now the property of Mr. Heywood. The Decoy is situated near the source of the estuary of the River Alde, on its south bank, and has six pipes.

The Iken Decoy has been of late very successful. It is in a quiet situation, about 300 yards from a road, and that a country lane, half a mile from the River Alde, and the land round it is in the owner's hands, which being attached to the Iken Hall Farm is kept very quiet, and it is the intention of the owner of the estate to continue to act thus for the sake of the Decoy.

No pheasants are turned into the Decoy wood, but it is shot through once a year for stray birds from the neighbouring coverts, and the Ducks are put out of the Decoy, before the wood is shot, early the same morning. The Decoy comprises I6 acres. The pond itself is 2 acres. The remaining $\mathrm{I}+\mathrm{acres}$ being marsh and underwood. The date when this Decoy was formed cannot be ascertained, but it is shown on an estate plan made in 1807 , and it is conjectured to have existed long previous to this. Many years ago it was fitted with nets for catching Pochard, as described at page 85 .

Table.-Showing Kill from i 878 to i 885 at the Iken Decoy.

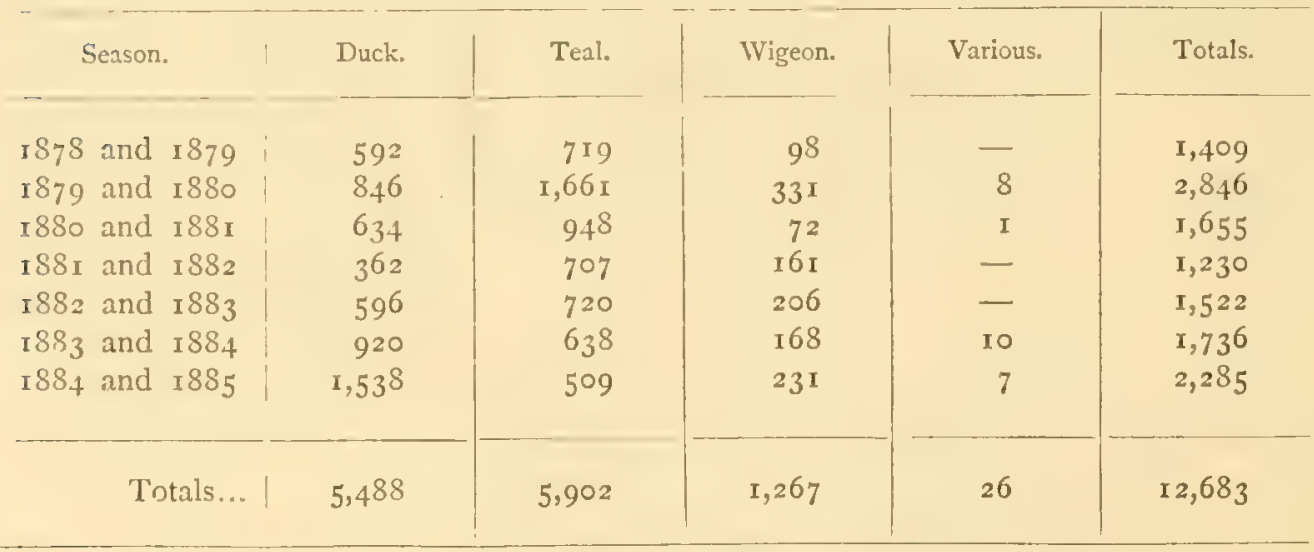

Chillesford Decoy, on the same estate, but 3 miles SW. of the last 
described, has not been a success of late years, owing to less care being paid towards keeping it quiet, its more successful neighlour at Ilicn having monopolized so much attention and interest.

It is, however, not in such a favourable position as is the one at Ihen, the public road, on which there is a great deal of traffic, lecing but 300 yards distant, and the village of Chillesford only a quarter of a mile. There is also a steam corn mill in its vicinity. The opinion of the Decoyman is, nevertheless, that if this Decoy had as much care and seclusion bestowed upon it, as is the case at Iken, it woukl improve greatly in its results.

The Decoy is close to Butley Creek, a ticlal estuary, that unites with the River Ore, some 2 miles above Orford Haven. Its size is 19 acres. The pond 2 acres, the remaining space being underwood and marsh, as is the case at Ifen. Its age is unknown, but it also appears on the estate may' of $\mathrm{I} 807$. Its yearly average is from 200 to 300 forw?

Orwell Park Decoy.-About fifty or sixty years ago a Decoy was constructed at Levington Heath, near Orwell Park, lyy Sir Robcrt I Iarland. It is four acres in extent, and when in full working order had five pipes. The present owner of the estate, Colonel George Tomline, worked it for many years, and then gave up doing so for a time. He states that the largest number of fowl he ever captured in one year was 3,000 . In $1853,2,380$ were taken; in $1854,2,279$; in $1855,1,803$; the total number of I)ucks secured in eighteen years lueing $2 \%, 9$, of which 5, - I I were Wigeon. At the present time only one pipe is rorlicel, in which during the scason of $I-\$ 4-55$ more than 7 co Ducks were taken by the end of November, but Colonel Tomline is now constructings a second pipe with the assistance of one of the Skeltons. There are some pinioned Wigeon here which breed frecly, and the young bircls are quite tame. A curious circumstance is, that although the l)ecoy is within joo to 400 yards of the Felixstowe Railway, the wildfowl appear to take no notice of it. In sharp weather there are great numbers of fowl in this Decoy, and Colonel Tomline has seen thousands asscmbled on the ice, and informs me he has lately met with such success that he intends fitting up the disused pipes again.

This Decoy is 5 miles SE. of Ipswich, and a mile from the north bank of the River Orwell, here a wide tidal estuary. It is three-quarters 
of a mile NE. of Nacton, and, notwithstunding the adjacent railway, is admirably positioned as a Decoy.

Nacton Decoys.-There are two ponds here on Nacton Heath, the property of Admiral Sir George Broke Middleton, Bart., of Broke Hall, one a small one of about an acre, for Teal, with two pipes, and another, almost joining it, of Io acres with six pipes, two of which are not now used. Nothing is known with certainty of the age of these Decoys. The present lessee of Broke Hall, Mr. Edward Banbury, is of opinion that the number of Ducks visiting the spot is nothing like so large as formerly, though in the late season $\left(1 S S_{4}-5\right) 500$ fowl were taken in one week, and as many as 1,700 in the season.

The Decoys are $2 \frac{1}{2}$ miles SE. of Ipswich; in the parish of Foxhall, and are sometimes spoken of as the Bixley or Purdis Hall Decoys. They are $2 \frac{1}{2}$ miles from the River Orwell, on its north bank, and three-quarters of a mile $\mathrm{N}$. of the Felixstowe Railway.

Fritton.-The lake at Fritton, 5 miles SW. from Yarmouth, and 6 miles NIV. of Lowestoft, is 3 miles in length, with an average width of 300 yards, and surrounded by large oak woods, a great attraction to the Ducks by reason of the acorns. Eight Decoy pipes are now in use, but the remains of thirteen others now disused are still visible, making twenty-one in all.

The only pipe worked on the north side of the lake, and that but cccasionally, is in the parish of Fritton, at the Hall Farm. Lieut.-Colonel Leathes, of Herringflect Hall, works three pipes (formerly five) at the Herringfleet or western end of the lake, and Sir Savile Crossley four more at the Ashby or east end, where there was originally a group of seven. Colonel Leathes says that he has no idea when his Decoy was first made, but that it is certain it has existed over 200 years, and that it has been worked by his family i 60 years.

When John Fisk (the old Decoyman previous to 18.48 ) made what he called "a good haul," Colonel Leathes says the stone pavement in the courtyard at the hall, which is close to the lake, used to be covered from end to end with Ducks taken in one day; it took 600 fowl to do this, and he could often average 200 Ducks per day for weeks; and Colonel Leathes also tells me, he recollects 600 Ducks being caught several nights in succession, and this at the Herringfleet Decoy alone, whilst equal takes 
were being macke at the Ashby end of the lake. ITithin the last fourteen years over 2,000 ducks have been taken at each end in one season, but lately the average has not heen 1,000 ; in $5 \$ 77-7$ s the take was very small. Success depends entirely upon the season and weather. Large numbers have been captured in November and March, but January and February are, as a rule, the best months.

About i 820 Colonel Leathes' Decoy used to pay $£ 300$ per annum, after deducting all expenses. Duck and Mallard formed the larsest portion of the fowl; then, in order, Wigeon, Teal, Pintails and now and then a few Pochards; Shovellers rarely of late, a few roosanders and a Gadwall or two. The proportion of the sexes seemed pretty even, but sometimes, though rarely, Mallards were taken without Ducks. There can be no doubt, says Colonel Leathes, that railways, threshing machines, and chainage, have greatly decreased the numbers of fowl of late rears; but the great evil has been the flight shooting up to the very banks of the Decoy.

In Colonel Leathes' Decoy, or, properly speaking, his end of the lake, all the pipes being on its south side they cannot work with a northerly wind; which is a great disadrantage. The practice has been to work this Decoy about sunrise and sunsct; lut often on a moonlight night (especially when the Ducks had been well ferl, and did not go on flight in consequence) a great number of birds have been taken, and old John Fisk used to say there was no time better than quiet moonlight nights.

There is a portrait of a large Newfoundland dog at Fritton Hall, painted by Cooper, with the I) ceoy as a background, which many years agro was a celebrated Decoy dog ; but generally a small dog is used, with the occasional addition of a red handlierchief round its neck. Ferrets are hereabouts by some esteemed even more than dogs, but being short-lived, they die almost as soon as they have completed their training.

At the Ashby, or eastern, end of the lake, opposite to Colonel Leathes', Sir Savile Crossley, Bart., works four pipes. There is nothing known as to the date of the construction of his group of pipes, which doubtless are as old as those belonging to Colonel I ceathes. The forl taken are likewise Duck, Teal, Wigeon, I'intail and showeller (the latter rarely); Pochards are seen in great numbers, but they are rarely caught. The best months are November and December for Duck; March for Teal 
and ITigeon. In this part of the Lake more males are said to be taken than females, perhaps eight out of twelve are males; and many instances have occurred of Mallards being taken without Ducks. The number of fowl caught since the year 1850 is known, and Sir S. Crossley, Bart., has kindly furnished some records. In $1867-8,2,278$ fowl were taken. In I 869-70, I, 483; I866-7, I, I $30 ; 1874-5$, I, IO4; I $864-5$, I, 063 ; 1868-9, I,045; I $878-9,1,533$; I $879-80,2,4$ I I ; I $884-5,2,048$; I $885-6,953$.

In 1884-5 some sharp weather set in about the 2oth of November, and resulted in 556 ducks being caught in three days, the catch on November 24 being 307 .

The usual, and most successful, method of working Colonel Leathes' Decoy pipes is, as said, by night. I will further allude to it, as it is one that the majority of Decoymen have never heard of.

Colonel Leathes says :-

"I need not mention to you that the rule is to work Decoy pipes before flight time, about 3 P.M., and again in the morning. Of course, I am aware that Duck, Snipe, W'oodcock, etc., 'flight' every evening.

"Consequently Duck are absent from a Decoy by night.

"Every rule, however, has its exception, and old John Fisk, the last of our clever Decoymen at Herringflect, used to tell me that the great thing is not to disturb the fresh fowl on their arrival carly in the season in the Decoy. To let them assemble and get well on their feed, which should be dross barley, Indian corn, and acorns if procurable. Then gradually to begrin and take the Ducks. That the Ducks, if well fed in the Decoy and provided there is no ice to break, will later in the scason relinquish their usual flighting at dusk"

Colonel Lcathes adds: "The fowl do, it is truc, take a flutter round the Decoy at sunset, but finding plenty of food always at hand for them in the Decoy precincts, they at length prefer to remain therein both day and night, till about the end of March when they leave in two big flights for the summer. It was when the Duck ceased to flight, and on moonlight nights, that old John Fisk used to make his big hauls of Ioo or 200 fowl at one drive, and 500 to 600 as the result of one night's Decoying."

This system of not flighting doubtless answers well on a large lake like Fritton, with an abundance of fowl on its waters and food at hand for them both natural and artificial. 



\section{PLAN OF DECOY WITH 8 PIPES. SCALE- 150 FT TO AN INCH.}

$100-50-0 \quad 100 \quad 200 \quad 300$

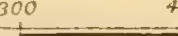

400 Feet

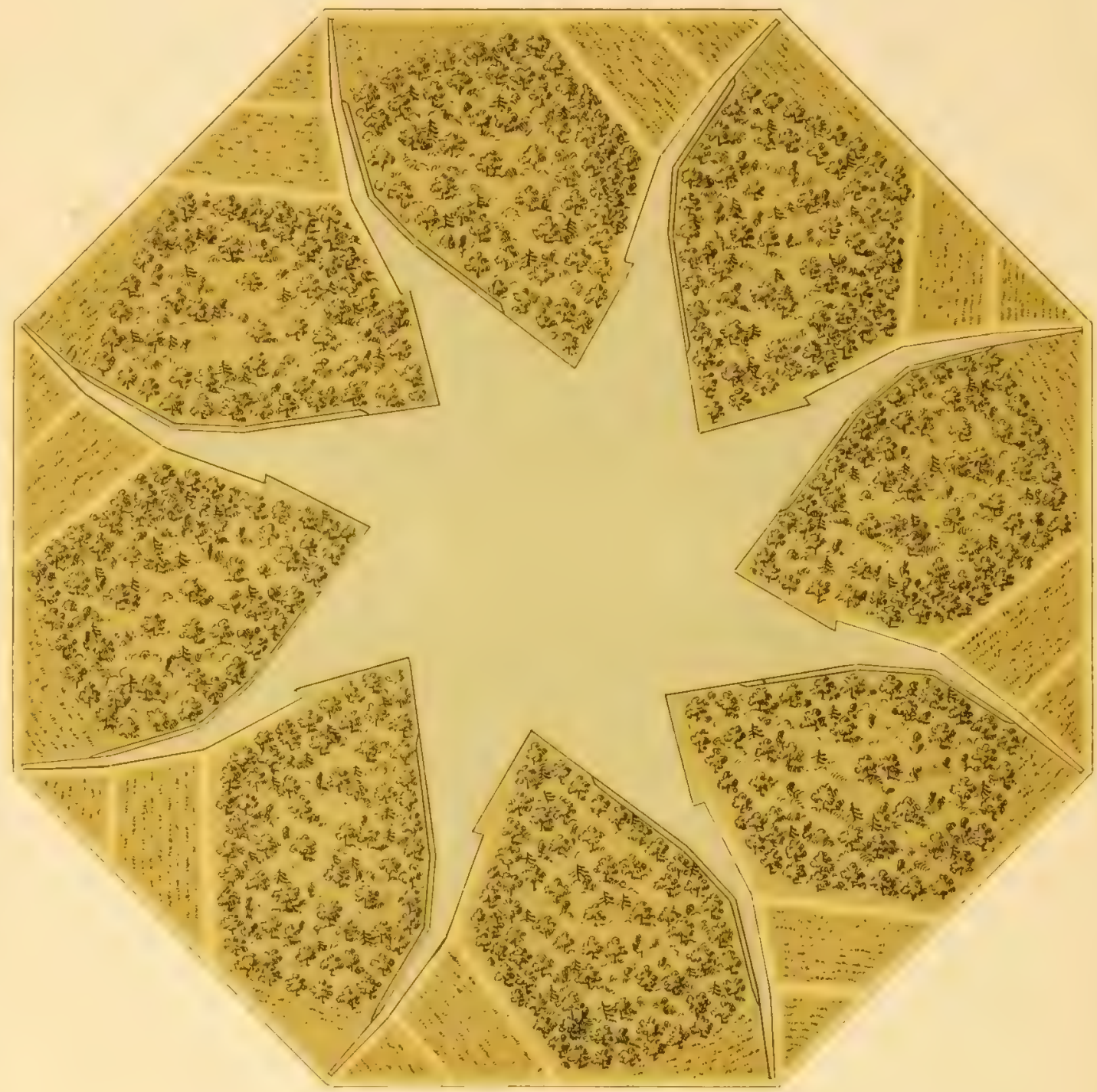

Blau -. Water

Green - Land.

Yellow_. Patis.

LAKENHEATH \& CALEDON. 
But in an ordinary Decoy, of an acre or so of water, the fowl will not bring in any companions from their nightly haunts, unless they fly to these spots from the Decoy, and so mix with and induce more bircls to accompany them to its seclusion on their return at dawn.

Lakculkexth, on the borders of Norfolk and Suffolk, within half a mile of the Decoy at Hockwold. It is north of Mildenhall, in Sedge Fen. The date of the construction of this Decoy is unknown, but Mr. H. MI. Upcher ascertained that it was for sercral seasons worked by Irilliams (see Wrangle), who hired it of Mr. W. Eagle. It was next taken by W. Skelton, who left it in IS 40 , and shortly after made Lord Caledon's Decoy in Ireland, in exact imitation of it. In one year Williams is said to have clearal near $£$ joo by the sale of wildfowl taken at Lakenheath. He used to send up a ton of Ducks to London twice a week in the season. An old keeper living in the parish in 1878 declared that he once saw fully 3.000 fow sitting outside this Decoy in the fen "waiting for those inside to be taken to make room for them," as the Decoy was so full "it looked as if one could not prick a pin in anywhere."

The Decoy has not been worked for more than thirty years, having been abandoned when the railway was made from Brandon to Ely, and it is now entirely grown up.

Mr. E. Fountaine, brother of the Rev. John Fountaine who made the Narford and Westacre Decoys, informs me that to his knowledye as many as I 5,000 fowl had been taken at Lakenheath in one season.

The Lakenheath I)ecoy, though some 50 miles from the coast, was probably the most successful onc of its day, owing to its wild locality and surrounding fens, which for miles on all sides were the resort of numberless wildfowl. It lies within a quarter of a mile north of the G. E. Railway from Brandon to Ely, on the south bank of the Brandon River, $7 \frac{1}{2}$ miles west of Brandon, between Lakenheath and Mildenhall Stations.

This and the Hockwold Decoy were so close together that they interfered with each other, though the latter was in Norfolk, just across the border of the two counties. No records are procurable respecting the age of the Lakenheath Decoy. (For a plan of it see page opposite.)

Binacre. In ISSo the late Sir Francis Gooch had a Decoy pipe constructed on the Broad near his resiclence, Benacre Hall, $4 \frac{1}{2}$ miles NE. of IVangford; but sorn after it was make the shooting was let, and the I) ecoy 
in consequence was never used; nor has it been worked since, the present baronet, Sir Alfred Gooch, preferring to shoot the wildfowl which resort there. This Decoy, which has but a single pipe, was planned by Page, Decoyman to Sir Savile Crossley at Fritton Lake, and is on the verge of the sea.

Friston, 3 miles SE. of Saxmundham, a mile N. of the River Alde, and the same distance south of Friston, the remains of an old Decoy, long disused, may here be seen. It lies to the left of the road leading from Aldeburgh to Snape and Friston, and is on the property of Mr. Wentworth of IVentworth Castle. It has not been used for fifty years, and no particulars concerning it are now available.

Brantham, I mile N. of Manningtree, near the inland extremity, and on the north bank, of the Stour estuary. - This was a Dunbird or Pochard pond, as well as possessing three Decoy pipes, and was ruined when the Great Eastern Railway cut right through its immediate vicinity. It is still a topic of conversation near Manningtree, amongst the old fowlers, of how on one occasion Sc, dozen Dunbirds were once taken at the Brantham pond at one rise of the net.

Flixton, $2 \frac{1}{3}$ miles IVN WI. from Lowestoft. -The remains of an old Decoy are to be found on a pool of some $\mathbf{I} 6$ acres at Flixton. The date of its construction has not been ascertained, and though traces of the pipes are still visible, Mr. Southwell was informed in 1878 that it had been then disused for at least fifty years. It formerly belonged to the Morse family.

Iforlingham, 7 miles IVSTV. of Lowestoft.-A Decoy existed here, of which the Author has been unable to obtain any particulars.

Campsey Ash. - The same may be said of the Decoy here, $\mathbf{I} \frac{1}{2}$ miles SE. of Wickham Market. It is on the River Deben, and once formed part of the belongings of Campsey Ash Abbey. 


\title{
HISTORY OF DECOYS-(contimued).
}

\section{CHAPTER XIV.}

\author{
Decors in the County of Surrey. \\ Decoys in zuse. \\ Decoy's not in use. \\ Virginia Water.

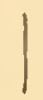 \\ Ottershaw. \\ Pyrford.
}

Virginia Water.-This large piece of water is 23 miles distant from London. On its north shore is what is known as the Decoy. This consists of two pipes within 50 yards of one another, situated in a dense overhanging bank of evergrecens, and a third pipe or channel, now disused, which was intended for a cage or trap-pipe, with a falling-door, as at Hardwick. The latter, however, proving useless, was given up soon after its construction.

The two pipes now in use are of small size, being but 45 yards in length and 15 feet across their entrances. They are of very primitive construction, and have no landings for the birds, or even banks for the dog to run along.

The growth of evergreens is so high and close on all sides that the pipes are quite sheltered from the winds suitable for working them, and it is therefore only by haphazard any fowl are caught. The pipes were laid out by the late head-heeper. Mr. Menzies, who took his ideas from the Milton Decoy, near Sittinghourne in Kent, with the assistance of its owner, Mr. Gascoyne.

Mr. Smith, the chief woodman at Windsor Park, who showed me this Decoy, and who has it under his charge, related that during the winter over $\mathrm{I}, 000$ wild Ducks might be sometimes seen at one time on Virginia Water, and now and then roo to i 50 fowl round the Decoy.

Mr. Smith uses but a couple of Decoy Ducks, and, from the faulty construction of the pipes, rarely a Dog. He has, howerer, cluring 
his supcrintendance of 20 years, on one occasion caught 35 Ducks at a drive, and once 50 in a day. The anglers and skaters who visit the lake and frequent the neighbourhood of the Decoy destroy any chance of its being successfully worked.

The birds taken here are exclusively Duck and Mallard.

Ottcrshaw Park, 4 miles SW. of Chertsey.

The remains of an old Decoy are still visible on this estate, formerly the property of Sir Thomas Colebrooke, Bart., but now belonging to Mr. Laurence J. Baren.

I learn, however, from the bailiff, Mr. G. Coleman, who has lived on the property for thirty-seven years, that it has not been worked within his recollection.

And the late owner of the estate, Sir T. Colebrook, informs the Author that there are no traditions existent connected with this Decoy.

Py'rford, $1 \frac{1}{2}$ miles NNIT. of Ripley, and 2 miles NE. of Woking.

In a wood of rather more than 8 acres in extent, and close to the right bank of the River IVey, may be seen the site of an old Decoy, with its pipes, five in number. It still bears the name of "The Decoy," although, as I am informed by the Vicar, the Rev. Mr. Ridsdale, there is no one in the parish who remembers its being used for that purpose.

Mr. George Pigot, who knows this old Decoy well from having once rented the shooting on which it is situated from Lord Lovelace, the owner of the estate, informs the Author "that the Decoy is now quite dry and overgrown with herbage, but that the pool and its pipes are still to be traced."

This Decoy was originally part of the property of Sir John Wooley, Latin Secretary to Queen Elizabeth, who pricled himself in having within his own estate every possible appliance for the provision of his table, and the wants of his household.

Thus, not far from the Decoy, is a place called the "Pigeon House," and there are still signs of the sluices which were cut from the old bed of the River Wey for the purpose of "Fish Stews."

The Decoy is surrounded by the River IVey, which here forms almost an island on all sides of it save to the north. 


\title{
Decoys in the County of Sussex.
}

\section{Decoys in use.}

Firle.

Decoys not in use.

\author{
Tangmere. \\ Angmering. \\ Tortington.
}

Glynde.

Ratton.

Peasmarsh.

Firle, 4 miles SE. of Lewes. - This is the only Decoy in use in Sussex. It is placed in Firle Park, the residence of Viscount Gage. It consists of a piece of water of four acres, with only one Decoy pipe attached to it.

The takes are small, and the pipe is used merely to supply the owner's table. Some years ago, before the clrainage of Pevensey Marsh, as well as the low lands round Lewes, the Firle Decoy was far more successful than is now the case.

This neighbourhood previous to its final drainagre was much frequented by Snipe, and within even the last half-dozen years as many as 500 Snipe have been seen collected at a time on one field near Firle.

Tangmere, 3 miles NE. of Chichester.-A Decoy existed in this parish, and near the borders of the parish of Aldingbourn. On an Ordnance Map of I $\mathrm{I}_{3} 3$ its exact position is shown on Aldingbourn Rise, near Castle Hill.

The Decoy has been disused many years, and the South Coast Railway (Brighton to Portsmouth) goes right through the site of the pooi. The old "I)ecoy House" has been lately renovated by the Duke of Richmond, but all traces of the Decoy itsclf have long since vanished. The land is part of the ancient domains of Halnaker House, the ruins of which are $1 \frac{1}{2}$ miles north of Tangmere village, and which was last inhabited by the Countess of Derby before the estate was added to the Ciondwood property.

Besides the I ecoy, there are various old Fish Sicws in the vicinity of Halnaker Inoce. and which were, with the Decoy, appurtenances thereof, 
At Angmering, 4 miles ENE. from Little Hampton, and about 3 miles E. of Arundel Castle, is a small Decoy the property of the Duke of Norfolk, but not at present used. It has been in existence for over a century. It was held for sixty-five years by a Dr. Knight, who was succeeded by a Mr. Snelgrove. It was next part of the Mitchelgrove estate, which was purchased by the then Duke of Norfolk, from a Mr. Walker, in 1832 . In 1849 or 1850 his Grace replanted it and made new pipes. Two of these are of iron, and a third has wooden hoops for the netting.

It was disused as a Decoy in I $\$ 6 S$, and has since that date only been risited for shooting. The Decoy proper is about an acre in extent, and it and the ponds adjoining are fed by natural streams.

No regular records have been kept of the fowl captured, but according to a statement of the late Decoyman, the largest number crer taken at one time amounted to rather more than 50.

This Decoy was constructed to supply Arundel Castle with wildfowl, but as it had occasionally large takes when they were not required, and at other times produced no birds when most desired, it was given up to the sport of shooting instead of Decoying. The Decoy is within half a mile of the village from which it takes its name.

The following letter (dated 1 \$25), alluding to this Decoy, written by the late Joseph Hume, M.P., the well-known statesman and author, to a friend in Norfolk, is well worthy of insertion here:-

"There is a Decoy at Angmering, about 5 miles from Worthing and the same distance from Arunclel. It is a quarter-mile south of the Brighton and Arundel road, and 3 miles from the sea. It has been established for two centuries, and from November to March supplies all the neighbourhood with Ducks, Teal, and Wigeon. ....

"There were formerly four pipes, but there are only three now. The pool is square, of about I acre, in a hollow surrounded by plenty of trees of different kinds, and is a secluded, quiet spot. There is a small rill of water runs down the hollow, and two or three large fishponds are on the $\mathrm{NE}$. of it, from which, one year with another, $8 \mathrm{cwt}$. of fish are drawn.

".... The Decoy pool has a strong spring of water in it, and they have the power of raising the water $12 \mathrm{in.}$ or $\mathrm{I} 4 \mathrm{in}$. when required.

"One man has attended this Decoy for fifty years, and his son is now assisting him. 
"They say that this Decoy is the best in the kingdom. ... The pipes are lower in the arch than those at Somerton in Norfolk. The sides of the pool are enclosed by reeded walls, rising about $3 \mathrm{ft}$. from the edge of the pool. . . . The insides of the reeded walls are all covered by ivy, so that, when on the Decoy pool, nothing but ivy is seen.

"The birds leave the pool regularly at clusk, scattering themselves over the country in every direction, and return in the morning before break of day. The largest number of birds ever taken in one day was 6o."

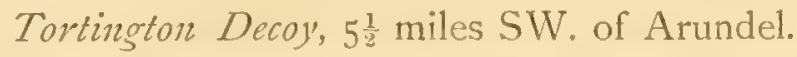

There are the traces of another Decoy here, also on the property of the Duke of Norfolk, and which estate was purchased by his Grace from Mr. Montefiore.

It is close to the railway station of Ford. It is now a dry willow bed, and the outline of the pool, said to be very ancient, can scarce be clistinguished.

Glynde, close to Firle, and 3 miles ESE. of Lewes.-There was formerly a Decoy here, on the estate of Viscount Hampden, but it has not been in use for a century, and only the wood in which it was placed remains to mark the spot.

Ratton Decoy.-At Willingdon, 3 miles NW. of Eastbourne, on the property of Mr. F. Thomas, there was formerly a Decoy. In consequence of the clrainage of the neighbouring levels and the great falling off in the number of wildfowl captured, it was given up about forty years ago.

The pool was from 2 to 3 acres in extent and had three pipes. It is now a reed bed, almost dry, and holding foxes.

Mr. IV. Brodricls Thomas, the uncle of the present owner of Ratton, informs me that he recollects this Decoy in working order, and that his father kept a most accurate Decoy-book, which cannot unfortunately now be found. He also states that his father inadvertently built some cottages for his labourers close to the Decoy; which disturbed it con. siderably, as, when the occupants cooked anything "savoury," erery bird left the pool at once.

Pcasmars/2, 5 miles NW. of Rye, I mile N. of Peasmarsh village, and $\mathbf{I}_{\text {1. }}^{1 .}$ E. of Beckley.-This Decoy consisted of two large pools separated by' a high bank, one for Duck and another for Teal. Traces of four pipess are still to be seen, but the wood in which the Decoy was situated has becn 
thoroughly drained, and so thickly planted, that traces of this formerly large and successful Decoy are now hard to find.

It has not been in use for 60 years, and is placed partly in Peasmarsh and partly in Becliley parish, south of the River Rother, on the property of Mrs. Pomfret.

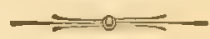

Decoys in tile County of Wariwick.

Decoys in zuse.

Packington Hall.
Decoys not in use.

Combe Abbey.

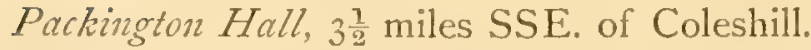

At one end of a pool of 30 acres a Decoy with four pipes was constructed by Williams of Wrangle, in I795. I am informed that the average catch for the last twenty years has been about 140 head; but the Decoy is only worked to supply the owner's wants. It is the property of the Earl of Aylesford.

Combe Abbcy, $5 \frac{1}{4}$ miles E. of Coventry.

In the year 1845 a first-class Decoy was constructed here by William Skelton. It has four pipes, and is placed close to the mansion, and is surrounded by several acres of osiers and reeds, with a mixture of spruce and other trees. The largest take in one year was 1,500 head, but of late years the number of fowl taken has been much smaller.

At the present time it is not worked, the lessee, Mr. Loyd, having recently removed the nets from the pipes, and expressed his intention of not using the Dccoy during the continuance of his lease, which expires in isSo. There is an extensive lake at Combe much frequented by wildfowl, and the I)ecoy in consequence formerly did well, though, like all other Decoys, it fell off in its takes of late seasons. T. Gilbert Skelton, son of IVilliam Slitton, told me he recollected his father, aided by himself, once catching Io6 Ducks at a drive in one of the pipes of this Decoy, in the presence of the late Earls of Craven, and Sefton. This statement is confirmed by Mr. R. W. Craven.

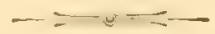




\section{PLAN OF DECOY WITH 4 PIPES, SCALE-I2O FT TO AN INCH. \\ 700 20ofeet}

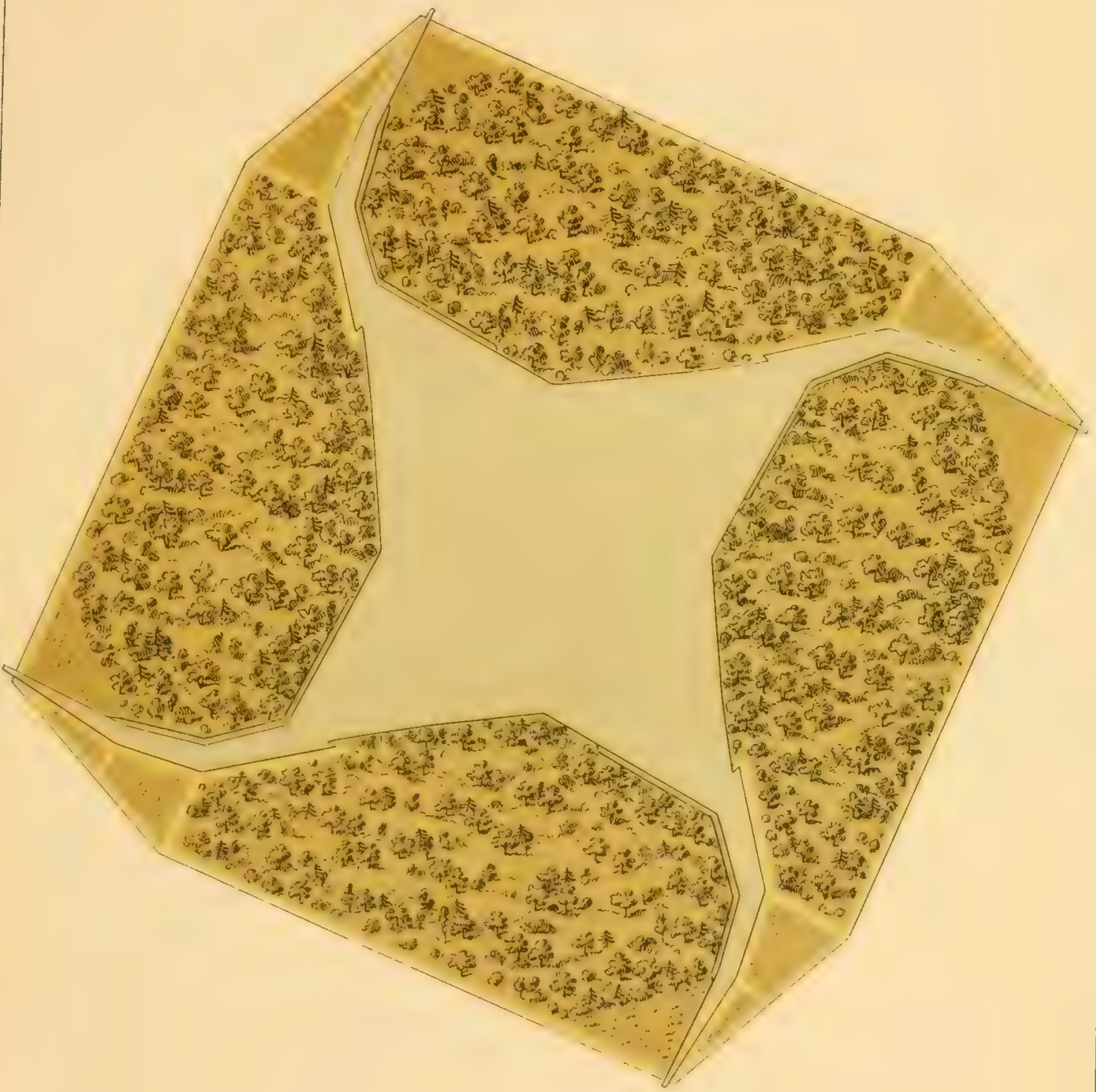

COOMBE ABBEY

Biace Waler

Green - Land

Yellow Paths. 

Decors in the County of Westmorland.

Decoys in ase.

None.
Decoy's not in use. Lowther Castle.

Lowther Castlc, the residence of the Earl of Lonsclale; 5 miles South of Penrith.-In the Park at Lowther is an oval-shaped pool of about 3 acres, known as the "Decoy." No pipes are now discernible, nor clo any records exist of this Decoy, other than that it was once used for catching Ducks.

It was the most northern Decoy in our Islands, and being adjacent to various rivers, and not far from the English Lalies, as well as surrounded by a wild and marshy country, was doubtless much frequented by wildfowl in days gone by.

\section{Decoys in the County of Wiltshire:}

\section{Decoys in use.}

Hampworth.
Decoys not in use.

None.

Hampa'enth, near Downton, a quarter of a mile from Hampworth Lodge, the residence of Mrs. G. Morrison, and II miles SE. of Salisbury.

In the autumn of I $882 \mathrm{Mr}$. G. Morrison constructed a Decoy with one pipe on a pool of about + acres, which has since been found to answer well. No dog is used, and only one Decoy Duck which is changed from time to time. The average annual take since its construction has been about 100 fowl, the largest number taken in one season being about 150 , and the most ever secured at a catch $5 \mathrm{I}$. The owner believes that from 300 to 400 might be taken in the season if clesired, for it is estimated that there are often as many as $\mathrm{r}, 000$ wildfowl on the water at one time during the winter. The Decoy has, however, only been used just enough to supply the house as wanted.

The waterhens are said to be very troublesome in giving the ducks warning when they get wind of the keeper who works it. It is believed that the ducks visiting this Decoy come from a long clistance, as they often appear so tired on alighting as to disregard all allurements for several day's on their arrival. The Decoy was constructed by the late Mr. G. Morrison after his visiting the one at North Stoneham in Hampshire. 


\section{HISTORY OF DECOYS-(continned).}

\section{CHAPTER XV.}

\section{Decoys in the County of York.}

Yokrsirke did not, like Norfolk, Suffolk, Lincoln, and Essex, boast many Decoys, as only a small area of its surface was adapted to attract wildfowl.

This portion was Holderness, in the East Riding, a district bounded on the east by the German Ocean, on the south by the Humber, on the west by the divisions of Hunsley and Bainton Beacon, and on the north by the wapentake of Dickering. Here were situated the principal Decoys of the county, in the valley of the River Hull.

The fens of Holderness were 20 miles in length, and from 4 to 6 miles in breadth, and extended from 7 miles south of Bridlington to the estuary of the Humber towards Patrington and Hedon, widening in their course as they approached the tide.

The drainage of these fens was first undertaken on the eastern side of the River I Iull (where Meaux Decoy then flourished) in 1762 , and an Act of Parliament was obtained to enable the promoters of the scheme to do so. Next came the "Beverley and Barmston Drainage Act," in I 798, parallel to the last but opposite, on the west sicle of the River Hull. Then, in I Soo, the "Hertford and Derwent Drainage Act" still further reclaimed the low marsh lands that bordered on Holderness, and a short time previous to the last Act Spalding Moor, to the west of Holderness (on which was Holme Decoy), and Valling Fen were drained and cultivated by private enterprise.

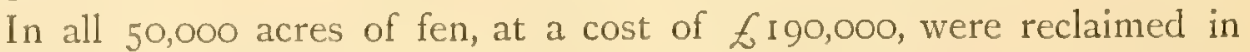
this division of Yorkshire.

Excepting Holderness no part of the county in former times was resorted to by wildfowl in large numbers.

As Yorkshire consists of so much arable land, mountain and heather, 
with a seacoast on one side only, and that devoid of ooze-banlis, it is naturally not much frequented by the aquatic species. Let the most favoured portions of the county for wilkfowl are still the lowlands of Holderness, and the shores of the Humber estuary. Long since, williowl abounded in the marshes that circumscribe the estuary of the Tees, but with the introduction of railways, blast furnaces, and steam resscls, they have deserted that locality.

Decoy's in use.

Hornby Castle.

Thirkleby Park.

Decoys not in use.

Coatham.

Escrick (2).

Osgodby.

Meaux.

Watton.

Scorborough.
Holme.

Sunk Island.

Thorne.

Goole.

Birdsall.

Hornby.-In the park at Hornby Castle, 5 miles NW. of Bedale, are two Decoy ponds, one disused, and the other, till lately, the only example of a Decoy in use in the county. The original Decoy was constructed for the seventh Duke of Leeds, in 1854. It is 7 acres in extent, and has the remains of four pipes. In issz, the present Duke moved the material of the pipes from the old Decoy to their new position. The original Decoy is situated south of the Castle, between the Sitone Pond and the present Decoy, which is now in the Blessington plantation close by.

The new pipes were excavated under the direction of Lord Fitzhardinge's Decoyman, from Berkeley Castle. The new $1,0 u l$ is about 60 yards square, and the pipes are at the corners, as is the case at Berlecley Castle and other Decoys in the west of England. The old I eecy was found to be too large, the fowl keeping out of reach of the pipes and of the Decoyman. The new Decoy, being much smaller, is more easily managed, and is precisely similar to the one shown facing pase 93.

The first pipe made at Hornby on the old Decoy was made by Harrison, Capt. I lealy's Decoyman at Ashby in Lincolnshire. Soon after, 
T. Gilbert Skelton made another at the NW. angle of the lake, and lastly, old Georse Skelton (junior) and the Rev. Mr. Fountaine added a third and fourth in $I S_{5} 6$. Finally, in ISSz, as stated, the present Duke of Leeds removed the netting, screens, and hoops to the new Decoy hard by, and completed it with four pipes. Among a variety of birds taken at Hornby a Harlequin Duck once occurred, and was preserved by the late Decoyman, Savage.

This Decoy averages from 300 to 400 ducks a season, chiefly Mallard and Teal. On one occasion only has 1,000 birds been exceeled: in that instance some 1,500 were taken by Barrett, the present Decoyman. The late Decoyman once captured 250 fowl in a morning, and several times 50 to 60 Duck and Teal have been taken in this Decoy at a drive.

The Hornby Decoy, like the one at Osgodby, was constructed owing to the successes reported at Mr. Healy's Decoy, in the neighbouring county of Lincoln. The owner of the Hornby Decoy related to me that the Greek guide who was with Lord A. Hervey, Mr. H. Coore, and others, at the time they were captured by brigands, when yachting in the Mediterranean, and who arranged their ransom (and maybe captivity), visited Hornby when being entertained in the neighbourhood.

Nothing he had previously been shown in England aroused his interest so much as seeing the ducks decoyed.

The treachery and cunning exhibited stirred his national instincts, and he is stated to have returned to his own country vastly impressed with all he saw in the Decoy.

Perchance he considered whether something of the kind could not be constructed to entrap rich, roving English sportsmen, without the necessity of threatening death from behind a rock, $\grave{a}$ la brigand.

Thirklcby Park, 3 miles S. of Thirsk. - I have lately (IS85) constructed a Decoy here. It consists of I acre of water and has 3 pipes, and resembles in form Lord Lilford's in Northamptonshire, and is shown on the plan facing page 55 .

Coatham, near Redcar.-On the estate of the late Mr. A. H. Turner Newcomen, of Kirkleatham Hall, a Decoy was constructed in Coatham marshes in 1840 . The area of ground enclosed for the purpose was about 3 acres, with a pool of two acres, the extent of water being occasionally increased when the marsh was flooded. 
There were four pipes, two of which only were in regular use, each 50 yards in length. The exact position of this Decoy may be describecl as on the east side of the railway at Ted Point, hetween Eston and Redear, and almost directly opposite the present kennels of the Cleveland Foxhounds.

Some five-and-twenty years ago this Decoy was very productive, when the Tees Bay and neighbouring marshes were much frequented by willfowl, as many as 100 Ducks and Wigeon having been taken at once in a single pipe; though on this occasion, owing to the weight of fowl enclosed, the net broke and the greater number escaped. Pint after the erection of blast-

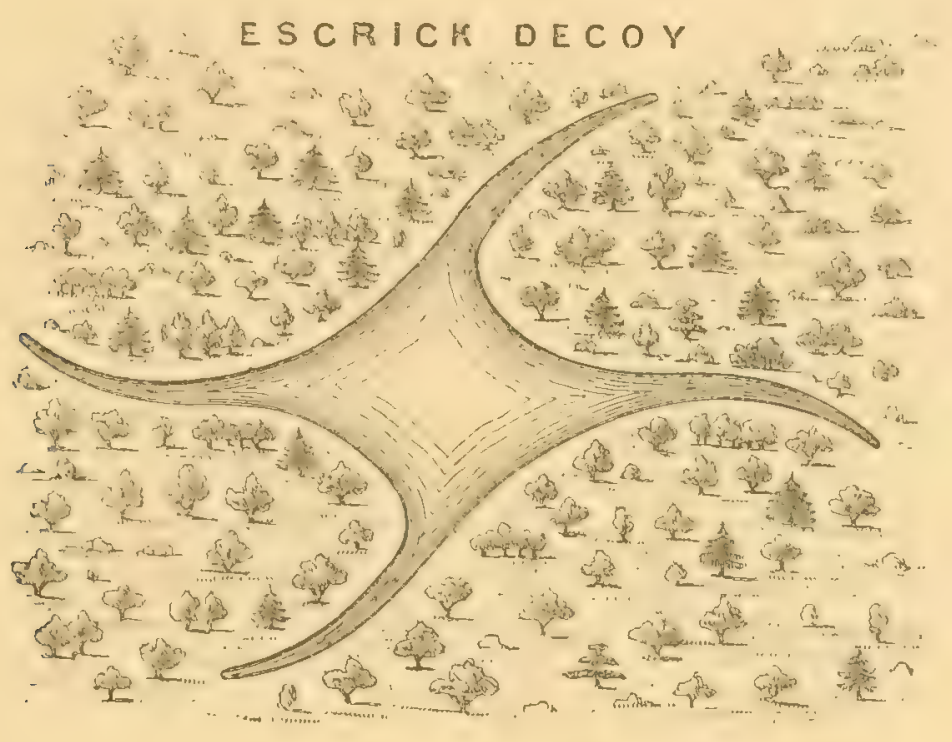

furnaces at Ted Point in 1872 , and the proximity of the railway and kennels, the wildfowl have deserted the spot, and the Decoy since that date has Leen alsandoned. Nothing now remains but the pool with a few stunted bushes growing near it.

Escrick Park, 7 miles south of York, the seat of Lord Wenlock. There were formerly two Decoys here, one of which, made by old George Skelton, about I830, with four pipes, was used until the year 1860. The formation of an island in the pool operated prejudicially, for fewer fowl were subsequently taken, and it was eventually abandoned. (of the other I) ecoy, situated in the park, some 200 yards only from the mansion. 
nothing now remains but a stagnant pool overgrown with rushes, no trace of the pipes being observable. Tradition, however, states that when in working order, about 2,000 fowl were taken therein in a season. The more recent Decoy is to be easily traced, its form being compact, well-shaped, and planted. It is, however, though in the park, within roo paces of a high road. The iron hoops, remains of the screens, and the Decoyman's hut, are still to be seen.

This Decoy was made for the late Lord Wenlock, and the present owner of Escrick recollects seeing ducks caught in it when a boy.

Osgrodby Hall, 3 miles east of Selby, formerly the property of $\mathrm{Mr}$. G. P. Dawson, but now belonging to Mr. Riley Briggs, possessed a Decoy which was last worked in 1877 . Situated at the north side of the park in the centre of the estate, it had four pipes, and some years ayo answered very well, an average season, as I am informed by its owner, producingsome 1,600 to 2,000 fowl. Mr. Briggss states he has occasionally seen as many as 1,500 birds on the pool at one time. If put into repair and working order, this Decoy might again be worked with advantage, as there is a large extent of water in the Humber estuary not far distant, on which the fowl collect in winter, whence many would doubtless find their way, as formerly, into the Decoy.

The Osgodby Decoy was originally planned about $\mathbf{1} 840$ by $\mathrm{Mr}$. Edward Dawson, son of the former owner, after his seeing Mr. Healy's Decoy at Ashby in Lincolnshire. It was found that there were more Teal taken in the east pipe, and more Duck and Mallard in the south pipe, than in any other. In the best season of which any record has been preserved, there were captured I, Soo Duck and Mallard, besides $500 \mathrm{Teal}$ and Wiseon. The last-named began to discontinue their visits about i 8 years ago. As many as So Duck have been taken in one pipe of this Decoy at a single drive.

Between the years I 762 and I Soo four ancient Decoys ceased to exist not far from Beverley, in East Yorkshire. These were-Meau, Holme, Ilitton and Scorborongh. No records of their age exist, or of the exact date when they were discontinued.

Mearx. - This Decoy lies $2 \frac{1}{2}$ miles due east of Beverley, $\mathrm{I} \frac{1}{2}$ miles on the east side of the River Hull, and a mile north-west of the once famous Abbey of Melsa or Meaux, so closely associated with Beverley Minster, 
and so rich in historical traditions. It is also a mile west of the village of Meaux, and $\mathrm{I} \frac{1}{2}$ miles ENE. of Weel.

A few hundred yards to the west of the Decoy stands an old low building, now used as a farm-house, and known as Butterbump Hall, a name derived from the number of Bitterns which formerly bred in the adjacent marsh. The Decoy stands at the edge of a large extent of lowlying land, and must in past days have been almost surrounded by marsh and water.

Its decay as a successful Decoy would date from 1763 , for in that year (4 George III.) an Act was passed for draining the marshes in Holderness that surrounded Meaux, and several more recent Acts, such as the Beverley and Barmston I)rainage Act of $1798, *$ for the same purpose still further destroyed the avocation of this and other adjacent Decoys, by reclaining from the wildfowl their old feeding-grounds.

These marshes-or, as they are locally termed, Carrs-existed not only at Meaux, but also at Scorborough and Watton, where the other Decoys alluded to flourished, and which were not far distant.

The carrs extended from Beverley, to near Barmston and Bridlington, and comprised i 1,000 acres. The outline of the Meaur Decoy and

* "Beverley and Barmston Drainage Act, 1798.

"Satisfaction to be made for Decoys.

"Whereas Richurd Sarage Lloyd, Fisquire, is or claims to be seised or possessed of a certain piece of water and certain land at Watton contiguous thereto, which for many years last past have been used as a Decoy for the catching of wildfowl:

"And whereas Sir Charles Hotham, Baronet, is or claims to be seised or possessed of a certain other picce of water and certain land at scorbrough contiguous thereto, which for many years last past have been also used as a Decoy for the catching of wildfowl :

"And whereas the said Decoys will be rendered useless or greatly injured when the said low grounds and carrs are drained and improved as directed by this Act, and by reason thereof the said Richard Savage Lloyd and Sir Charles Hothan and their heirs respectively will be deprived of receiving any or so much rent as they now respectively receive or are entitled to account thereof: Be it therefore enacted that the said Commissioners shall make such reasonable recimpence and satisfaction to the said Kichard Savage Lloyd and Sir Charles Hotham respectively for the damages which they shall respectively sustain by the means aforesaid as shall be agreed upon between the said Commissioners and the said Richard Savage Lloyd and sir Charles Hotham respectively, the said Commissioners in making such recompence having regard to the frobulite improvement which the land in the I) scoys shall respectively receive from the suid drainge when the same shall be effected." 
its pipes is still plainly to be discerned, and it could even, if desired, be again put in order for use.

It is evident the Meaux Decoy was not in existence in the days of the monks of Meaux Abbey, or it would assuredly have been alluded to in the writings of the time, which were both accurate and not few in number in regard to the district.

Meaux Abbey was founded in 1150 , and its noble foundations broken up on December I I, 1539, on the dissolution of the monasteries by Henry VIII. In the History of Meaux Abbey, no mention is made of a Decoy

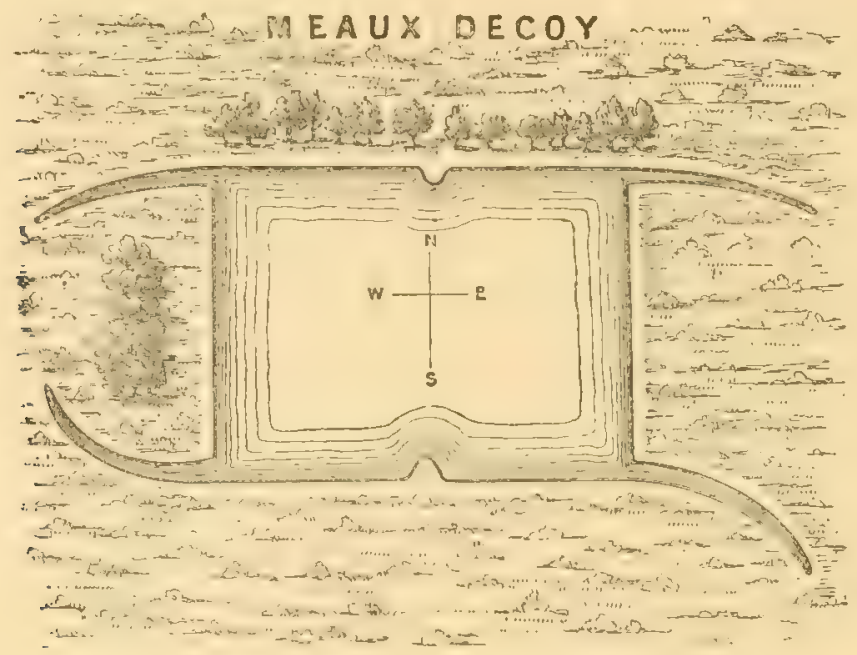

in connection with it, nor does such occur in the History of Watton Abbey, where a Decoy also existed.

In the Histories of our Abbeys, the Deer, the Fish, and the Game are all treated of, and the numerous artifices of the chase, but the subject of Decoys is not entertained. In the Northumberland Houschold Book, written at Leckonfield, within 3 miles of Beverley, and adjacent to Meaux, no entry or mention is mack of the Iecoys, which most certainly would have been the case had they then heen in existence. The Book commences from I5I2, and the Castle was pulled down in 1650. It gives minute particulars of the purchase of "wildfowl" for my lord's own mess. They were to be bought first-hand. Particulars and directions are also 
given therein as to the taking of "Swans" to fatten "from my carrs of Arrom," in which carrs, by the way, the Scorboroush Dicoy was situated. So that if the Decoy existed in those days some reference would surely have been made to it, for its locality and the surrounding marshes then belonged to the Earl of Nurthmberland, especially as all the minutice are so carefully entered in the Book, such as the prices of the various wildfowl, and even a copy of the warrant sent to the swanherd. I malie the above remarks because it is popularly supposed that the 11 eaux and IVation Decoys were either monastical belongings, or existed at the time of the monks, and so were contemporary with the Northumberland I Lusschold Book.

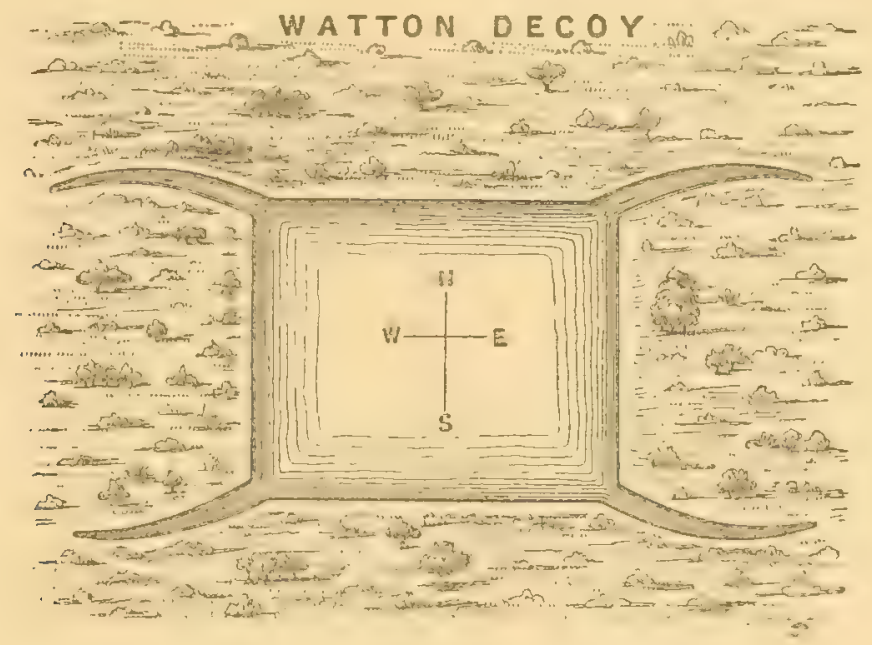

Redshanks and one or two pairs of Gar saneys still breed in these carrs. Ruff, too, have been obtaincl several times in the breeding season about them, also Gadwall and other of our rarer Ducks.

Watton.-Mr. H. W. F. Ellis of Crowle, who has made careful researches, informs me that this Decoy had an area of 1,000 acres of marish and water round it, and was very productive, yiclding at times as many as 400 ducks daily before drainage sealed its fate.

The Decoy is situated 7 miles north of Beverley, between the high road from Beverley to Drificld and the River Hull, and like Scorborough Decoy, from which it is distant + miles in a northeriy direction, it also lies in the valley of the Hull river. The Watton Decoy exactly resembles the 
one in Sharpham Park near Glastonbury, which latter is said to have been in existence when Sharpham belonged to the Abbey of Glastonbury.

Scorborough. - This, like the Watton Decoy, was once a very noted one. It is situated $2 \frac{1}{2}$ miles NNE. of Beverley, on the west bank of the River Hull, and in the low-lying land between the river and the high road from Beverley to Driffield.

Though trees have grown up in and round it very thickly; still the pool and the pipes are plainly risible, and it is evident that much care and expense was in former times bestowed upon it. The site of the Decoy was well chosen, for even now, when there is an overfluw from the river (formerly an annual, now an occasional occurrence), wildfowl resort to its vicinity in considerable numbers.

Holme Decoy was contemporary in its decay with those at Meaux, Watton, and Scorborough, and was placed on Spalding Moor, also in the East Riding of York, and 5 to 6 miles SW. by W. of Market Weighton.

This clistrict, and to the $\mathrm{E}$. of it Walling Fen, formerly comprised a large extent of wet moor and fen-land, and there are now several large ponds in the neighbourhood, such as Hotham and Houghton ponds, where wildfowl still assemble in considerable numbers in severe weather.

Allen, in his "History of Yorkshire" ( 829 ), alluding to Spalding Moor, remarks that, "People then living could recollect when this moor and its neighbourhood was one great morass, that extended from Holme upon Spalding to Howden on the River Ouse, Io miles distant."

In my notes of these old Holderness Decoys, I have been most kindly assisted by Mr. F. Boyes of Beverley, who not only supplied me with useful information, but, by surveying the pools, has enabled me to give correct outlines of their shape.

Sunk Island.-A Decoy was constructed here about the close of the seventeenth century, but owing to its exposed position neither trees nor underwood could be induced to grow round it for shelter, and consequently it was abandoned soon after it was completed. (Allen's "Yorkshire," I 829.) *

* In "Leland's Itinerary" is a letter from the Rev. Francis Brokesby, dated in the year I III, in which an account is given of the state of Sunk Island at that time, and in which this Decoy is alluded to. Mr. Brokesby says: "Sunk Island was spoken of as a novelty when I first went into Yorkshire, forty-four years ago (I667), a little after which time this Island was bestowed on Colonel Anthony Gilby, then Depuly-Governor of Hull, by a grant from 
It was admirably placed, as the neighbouring estuary of the Humber, a vast extent of water and ooze, was then the resort of immense congregations of wildfowl, and is even now in hard weather. There is at this date no trace of the Decoy, though on some maps a "Decoy Creek" is marked. Sunk Island is in the southern division of Holderness in East Yorkshire, on the north bank of the Humber, and 12 miles SE. by E. from Hull. This island was gradually reclaimed from the sea; 200 years ago it consisted of but $\$ 00$ acres, and a broad navigable channel separated it from the mainland, over 2 miles in width. Now (1885) the so-called island (for the channel has disappeared long since) comprises 7,000 acres of Crown land in a high state of valuable cultivation. In IS29 Allen describes Sunk Island as containing 4,000 acres.

Thome Iraste is 4 miles S. of Goole, and in the West Riding of Yorkshire. There existed a productive Decoy here, north of the Keadby Canal, on the moor some 2 miles west of Crowle, which small town is situated on what is known as the Isle of Axholme, at its NV. extremity, near the River Don, just over the border of Yorkshire, in Lincolnshire. There are no records of the Decoy or its successes, but Mr. Henry Ellis, of The Nanor House, Crowle, distinctly recollects it in use, and to him I am indebted for what few notes I can supply of it, as well as for the interesting account of Thorne Waste appended.

In 1836 the Decoy was in full work; it ceased to be used about the year I $\$ 40$, as by that time a considerable extent of the moor had been drained. The Decoy was an acre in extent, and had three pipes as well as a Decoyman's hut close by. Its site is now almost undistinguishable, and is covered with small beech-trees, and various mosses and other products of the moor; but Mr. Ellis tells me that, knowing its exact position, he has no difficulty in finding it. In the "History and Topography of the Isle of

King Charles II. It is reported to have been at first a great bank of sand (of which there are still many to be seen in the Humber at low water), that thereat other mud and natter stopped till it arrived at its present bigness. The island, when it was given to Colonel Gilby, was never quite overflown but at spring tides. At neap tides it was constantly dry. It is reckoned about seven miles about, and is separated from Holderness by a channel nearly two miles broad. . . . There are near 2,000 acres enclosed by high banks to keep out the sea. .... Some years ago they made a Decoy upon the Island, which is plentifully stored with wildfowl, especially Ducks and Teal, but it turns to little account for want of trees, which will not grow well here, as the ground is too salt." 
Axholme" (an island formed by three rivers, the Trent on the east, the Don on the north and west, and the Idle on the south), by the Rev. IV. B. Stonehouse, M.A., written in 1839 , p. 422 , the author remarks:-

"A small Decoy yet lingers on part of the common (parish of Crowle), where wildfowl are occasionally taken, just sufficient to remind the modern sportsman what a diversion the ancient fowler found in these extensive and wild resorts of the feathered race."

Before the drainage of the marsh lands adjacent to Thorne, at Hatfield and Goole Moors, by Sir Cornelius Vermuyden, of drainage fame, who having spent $£ 200,000$ in doing so, died in poverty at Crowtrees, near Thorne, the district abounded in wildfowl of every description. It was near here, at the mouth of the Trent, that the last Avocet's nest found in England was discovered in I $S_{4}$. Thorne Vaste or moor lies 8 miles south of the River Humber at Goole, and between the small towns of Crowle and Thorne, and on the north side of the Stainforth and Keadby Canal.

This waste is an extensive morass of about 6,000 acres, 500 of which have been apportioned to Crowle; its depth averages I 2 to I 5 feet, and in some places many more; a fact attributable to the fine qualities of the soil beneath. Below are the remains of an extensive forest, consisting of oak, beech, birch, willow, and other trees, and which forest evidently at one time covered an immense tract of ground in this part of the country. Generally speaking, these trees are in a remarkable state of preservation, and the wood is used for posts, rails, and laths. The destruction of the forest will in a measure, no doubt, account for the existence of the moor. Anyhow, its formation is an interesting subject, and was probably aided by a subsidence of the land, for at the depth at which these trees are found they could not by any possibility now grow. In various parts of the moor, especially the central, are small lakes or pools of water, upon the margin of which IVild Ducks and the Blackheaded Gull (Lamus rirdibundus) breed. Wild Geese also frequent the moor, as do Plover and other birds. Several kinds, however, that formerly made their appearance are not now to be seen. Amongst reptiles, the adder or viper (Pclias berus), and the common snake (Natrix torquata), are to be noted. Dragon flies abound near the pools, and, on a still summer or autumn evening, what are here called "midges" (the Culcx reptans a very small black gnat with transparent wings), are very troublesome, not so much 
on account of their bite, but because of their creeping over the skin of the face and neck. Numerous bog plants and mosses are to be found on the moor; but, through the cutting of drains and ditches, many of these are gradually becoming extinct. The Drosere, Sundews, the Erica, Heaths, the Andromeda Milampyrum, or Cow Wheat, and My'rica Gale, are abundant, as are various Carices, but not the (Immenda. This moor is being gradually reclaimed by the process of warping and other means, and from the peat, charcoal is now extensively manufactured and sold for ayricultural purposes.

New Zealand.--In 1850 the late. Mr. Durham, who owned a large part of Thorne Waste, partly constructed a small Decoy on a portion of the moor known as "New Zealand," near Thorne. It was made on the plan of the Decoy at Ashby, but was never properly worked, and is now out of order.

Goale Old Decoy.-A Decoy that has not been worked since the early years of the present century, existed near the south bank of the Dutch River, near its junction with the Humber at Goole, 6 miles NNE. of Thorne, on a large extent of marsh, in those days known as Greenland. A farm, called the Decoy Farm, still marks its position; and a house close by the latter, at one time an inn, had for its sign "The Dog and Duck"-a name possibly suggested by the vicinity of the Decoy. Some few years back the shape of this Decoy was easily to be traced, but it is now grown up and lost to view.

Goolc Ncw Decoy.-Another Decoy + miles west of the latter is shown on several old maps the Author has examined, also on the south bank of the Dutch River.

Being marked new Decoy it is probable it was either started in rivalry of the last mentioned, or else to take its place on Goole, soon after the commencement of the present century, increasing in size from a hamlet to a busy town.

Birdsall.- The site of a Decoy is shown on old maps at Birdsall, near North Grimston, 6 miles SSE. of Malton.

This was not a pipe Decoy. It was near Birdsall House, the seat of Lord Middleton, to whom the estate belongs, and who tells me it was a trap or cage Decoy (see page $; \mathrm{I}$ ), and that it has long since been discontinued and is now nearly silted up. 


\section{HISTORY OF DECOYS-(contimed).}

\section{CHAPTER XVI.}

SCOTLAND.

Curious to say, I have no evidence that a Decoy was ever worked in Scotland, either for amusement or profit. That Decoys, especially on the east coast, with its large estuaries and feeding grounds, could be successfully established in Scotland is beyond doubt.

None of my friends or correspondents ever heard of a Decoy in Scotland, though many of them, especially the late talented Author and Sportsman, Mr. J. Colquhoun, express surprise at their non-existence, as well as remark upon the many favourable localities suitable to their construction.

It is true that a Decoy was commenced by Major R. Chadwick, of Moy, near Findhorn Bay, nortl of Forres, but it was never completed. 


\title{
HISTORY OF DECOYS-(contimed).
}

\section{CHAPTER XVII.}

\author{
IRELAND.
}

County Cork

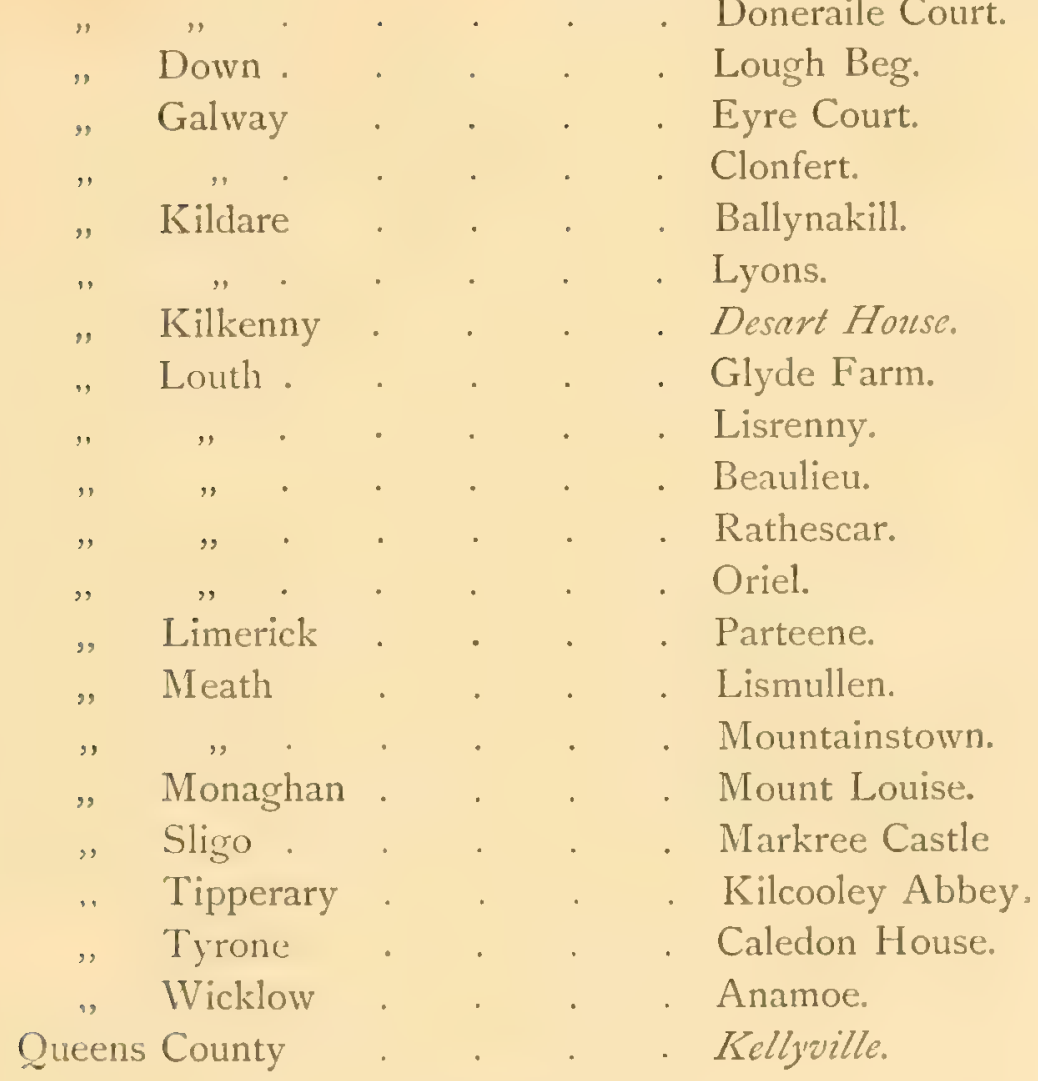

DECOYS IN IRELAND.

Thoush most admirably adapted by nature for the purpose, Ireland never possessed many Decoys, and at the present date (ISS5) has only three in use, namely, those given above in italics. 
With the exception of some half-dozen out of the twenty-two past and present Decoys of this island, I have little but what is secondhand information. The reason being that most of the Irish Decoys were discontinued many years ago.

That several other Decoys formerly existed than those hereinmentioned is probable, but though I have travelled the length and breadth of the island, both inland and by the coast on various sporting expeditions (aide "Fowler in Ireland"), and have constantly made inquiries on the subject, it has been with but meagre results. This information, such as it is, is now given.

County of Cork.
Decoys in use.
Decoys not in use.
Longueville.
Doneraile Court.

Longucille (2), 3 miles IV. of Mallow, the residence of Richard Longfield, Esq.

The Decoys are situated three hundred paces below the mansion on the south sicle of the park, and close to the high road from Mallow to Kanturk.

They consist of two pieces of water, one being 35 yards square, and the other close by and connected with it, being $S$ to 10 acres in extent.

The original Decoy, the small one, was constructed in 1750 , and had four pipes, two of which were enlarged in $\mathrm{I} S 65$ and two abolished. In I 875 Mr. Longfield made a new pipe on the large piece of water hard by, or, as it is called, "The New Decoy."

The takes in a season vary from 250 to 300 fowl. In the winter of $1 \& S_{3-4}, 4+$ Wild Duck were taken at a drive. But an average good catch might be 15 to 20 birds; the last made pipe being the most successful.

Thompson, in his admirable work, "The Natural History of Ireland' ( $185 \mathrm{I}$ ), thus alludes to this Decoy. He writes: "In the season I 840-4 I, 2 I6 Teal, roo Wild Ducks, and I Wigeon were captured. . . . . The greatest number taken here for some years past was in $1 S+5-46$, when 730 head of Duck, Teal, and Wigeon were procured." He adds : " 70 
Ducks and Teal have been taken at one time." As an instance of how soon wildfowl learn to discriminate between real danger and the reverse, I can say that I have seen the Ducks at Longueville sitting composedly on the Decoy, within sight and sound of carts and wagrgons passing along the adjacent road, a distance of but ioo paces, and though the drivers of such vehicles can see the fowl, and mischievously crack their whips to alarm them, their efforts to rise the birds prove futile.

Doncraile Court.-The residence of Viscount Doneraile, close to the town of Doneraile, and 6 miles NE. of Mallow. There are the remains of a first-class Decoy here, though no records exist of its being put ever to active use.

It was constructed by the second Viscount Doneraile, grandfather of the present owner of the estate, and much costly masonry was used in its construction, some of which is yet to be seen.

The outline of the Decoy can still be traced, and I have been able on a close inspection to determine the position of the four pipes. The remains of the Decoyman's hut are also visible, together with the channels cut for flooding the pool from the River Aubeg, that flows close by its side.

The Decoy is placed in a dense thicket in the park, and some 400 yards distant from the mansion.

The park at Doneraile abounds in wild scenery and magnificent timber; indeed, Lord Doneraile once told me that it used to be his boast, that some years ago he could point out, in his beautiful grounds, specimens of all well-known British trees, as well as many rare ones, that, taken collectively, could not, he was ready to wager, be surpassed in size and symmetry of form and foliage, on any other estate.

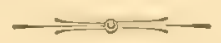

County Down.

Decoj's in use.

None.
Decoys not in use.

Lough Beg.

Thompson, in his 'Natural History of Ireland,' i $8_{5}$ I, before alluder to, writes:-

"Mcarlows on the margin of Lough Begr. connected with I_ough 
Neagh (on the eastern side), still bear the name of Coy Meadows, from the circumstance that there was a Decoy there at a very distant period." Lough Beg, this writer adds, was, in $185 \mathrm{I}$, "one of the finest haunts for wildfowl in the north of Ireland, Wild Ducks and Wigeon in particular are so numerous, and in such dense flocks as sometimes in calm weather, when most conspicuous on the smooth surface of the water, to appear like floating Islands."

Lough Beg is at the extreme northern corner of Lough Neagh, and is I4 miles NW. of the town of Antrim.

Decoys in use.

None.
County Galivay.

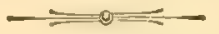

Decoy's not an use.

Eyre Court.

Clonfert.

Eyre Court, 7 miles W. of Banagher and I 2 miles N. of the shores of Lough Derg at Portumna. A small Decoy existed here till about i \$60, but Mr. Eyre informs me that it is now numbered with things of the past. Thompson, writing of this Decoy in I $85 \mathrm{I}$, says: " 40 to 50 Teal are often taken here in a day when the wind is favourable."

Clonfert, 2 miles S. of Shannon Bridge, where the Rivers Suck and Shannon unite. I have no notes of this Decoy. It was discontinued about 1820 , for Thompson writes in 1851 : "In the County Galway there was an extensive Decoy at Clonfert, but it was given up about 30 years ago."

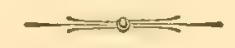

County Kildare.

Decoys in use.

None.
Decoys not in use.

Ballynakill.

Lyons.

Ballynakill.-Several sporting writers merely allude to a Decoy as having formerly existed here, but I am unable to obtain any reliable particulars of it. 
Lyons, the estate of Lord Cloncurry. A Decoy formerly cxisted here, but the owner of the preperty, who has kindly made enquiries of old residents, states that no particulars of it are now linown, or obtainable. What is called the Decoy is a small pool in a plantation near a much larger piece of water.

Lord Cloncurry says it certainly has not been used as a Decoy for forty years.

\author{
County Kilienny. \\ Decoys in use. \\ Desart House. \\ Decoy's not in use. \\ None.
}

Desart House, S.! miles SIT. of Kilkenny, the residence of the Earl of Desart.

The owner of this Decoy says "that of late years it has been nearly a failure.

"That though the Ducks come as usual in large numbers, very few are now taken compared to what used to be the case.

"Foxes also abound in the vicinity and manage to destroy most of the tame Ducks." Many years ago from 1,500 to 2,000 wildfowl was no unusual number to take in the Desart Decoy.

This Decoy was constructed early in the present century.

\title{
County Louth.
}

Decoys in zise.

None.
Decoj's not in zuse.

Glyde.

Lisrenny.

Beaulieu.

Rathescar.

Oriel.

According to Thompson, who wrote in $185 \mathrm{I}$, the Decoys at Glyde, Lisrenny, and Beaulicu had even in his day long been disused.

Also the ore at Rathescar (erected by a Baron Foster) was 
not in working order at the time of the publication of "The Natural History of Ireland,' nor was the Decoy at Oriel, 2 miles distant, then in use, though Thompson adds that formerly it was wont to talie sometimes as many as 60 couple of Teal in a morning.

\section{County Limerick. \\ Decoys in zuse. \\ None. \\ Decoys not in use. \\ Parteene.}

Partecne, a small hamlet about 2 miles IVNW. of Limerick, on the $N$. side of the River Shannon. In Donelly's Tour in Ireland (I68I), the following allusion is made to this Decoy, which must have been a very early established one.

"Parteene is a small town adjoining to the famous Salmon Weir belonging to the City of Limerick..... On the right hand of the bridge is a great Decoy for Ducks belonging to James Fitzgerald of the Middle Temple, Esquire.

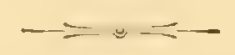

Decoys in use.

None.

\section{County Meath.}

Decoys not in zuse.

Lismullen.

Mountainstown.

Lismullen.-This Decoy has not been worked for many years, not since about 1840 .

Monntainstown, like the former, has long been discontinued.

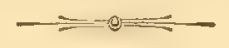

County Monaghan.

Mr. R. Evatt, of Mount Louise, in this county, informed the Author that some years ago he attached a small Decoy-pipe to the lake in his grounds, but that, through non-success, it was discontinued. 


$\begin{array}{ccc}\text { Decoys in zuse. } & \text { County of Sligo. } \\ \text { None. } & & \text { Decoys not in use. }\end{array}$

Markrec Castle, $\delta$ miles S. of Sligo, the seat of Colonel E. H. Cooper.

A Decoy-pipe was constructed here in connection with a large lake of I 00 acres, but proved a failure owing to the large extent of water it was attached to. Another pipe was nearly completed, but given up by the owner on his finding the first pipe made did not succeed. Both were the work of T. G. Skelton, and were made about the year I860.

\section{County Tipperary.}

Kilcoolcy Abbcy.-There was a Decoy here on the property of the late Mr. C. B. Ponsonby. It was discontinued about i868. It was a small pool of but half an acre, with four pipes, and was made by Sir IV. Barker in 1750 , but was given up a score years ago, owing to its nonsuccess consequent on some large marshes near it being drained.

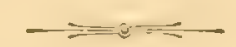

\section{County Tyrone.}

Decoj's in zuse.

None.
Decoj's not in use.

Caledon House.

Calcdon Honse, the residence of the Earl of Calcdon, $S$ miles NE. of Monaryan, in the southern corner of the county of Tyrone, where it touches on the counties of Monaghan and Armagh.

This Decoy, one of the best ever made, was constructed by Irilliam Skelton in I $_{4} 6$. It has eight pipes and in area consists of a little over two acres and a half. It has been out of repair for about a score years. In its successful days the Caledon Decoy sometimes accounted for from two to three thousand fowl in a scason, and on many occasions fifty to sixty Duck were taken at a drive, and now and then over a hundred. 
Thompson, in alluding to this Decoy, remarlss that Skelton, who in those days managed the Calledon Decoy, told him "that he considered there were as many wildfowl frequenting it, as was the case with any Decoy he was acquainted with in Lincolnshire." (See plan facing page I67).

County of Wickloiv.

Dccoj's in use.

None.
Decoys not in use.

Anamoe.

Anamoc.-According to Thompson a Decoy (long disused) existed here on a small river between Anamoe and the seven churches of Glendalough.

\section{Queen's County.}

Dccoys in use.

Kellyville.
Decoys not in use.

None.

Kiclyoille. Some years agro a Decoy with 6 pipes was made here, on a pice of water of 12 acres, by Capt. Frank Webber. It is situated on the borders of Queen's Co. and Kildare, near Athy, and is about 30 miles inland from the Irish Channel, and 3 miles from the Barrow river where there are extensive marshes.

In 1872800 fowl were taken here; in 1873 about 1,400 , and from that year until 1880, when Capt. IVebher gave the Decoy up to his brother, the average take annually used to be about I,500, the best year resulting in 1,960 fowl. Since 1880 two more pipes have been added, and Mr. W. D. Webber informs me that since then the largest take in a season has been 2,500 wildfowl, and that in the winter of $188_{3}-4,1,700$ Duck and Teal were caught in about equal numbers; no Wigeon, and only an occasional Pintail and Shoveller, though the latter species sometimes haunt the Decoy to the number of 50 or 60 together. 


\section{HISTORY OF DECOYS-(continued).}

\section{CHAPTER XVIII.}

\section{Decoys in Holland.}

As we are supposed to have originally derived our knowledge of Decoys, and the art of Decoying, from Holland, it may be considered within my province to allude to I) utch Decoys,-as well as to those in the neighbouring state of Schleswig.

Decoys, as may be surmised, are very successful in Holland, in consequence of the unlimited feeding-grounds that country and its shores and estuaries offer them.

Besides this the Dutch preserve and protect wildfowl to a far greater degree than is the case in our islands; no one for instance on their coasts being allowed to fire a gun within a thousand yards of a Decoy. The law of Holland regards a Decoy as an established system of trade engaged in by its owner or occupier; and so encourages and protects him in his avocation of Decoying.

I have not, it is true, made it a special study to learn the positions of all the Dutch Decoys or obtain notes of their successes; the latter feat would be a difficult task, for in I Holland Decoys are more or less shrouded in secrecy and their doings concealed from inquirers on the subject.

What information I have obtained, and am therefore able to lay before my readers, has been either through personal visits or throush sources that can be relied on. Such as it is, I can vouch for its accuracy.

From the examination of Government statistics, as well as-by reason of careful rescarches I have male, it is probable that there are in Holland and its islands fully jo to so I ecoys now in actire use. The immense total of fowl they take can therefore readily be conjectured.

Decoys abound in all parts of Holland, notably in Friesland, North 
Lrabant and Utrecht, besides several in Groningen, and the East Frisian islands.

There are some very successful Decoys between Flushing and Rotterdam, on the Islands, and near the shores, of the Scheldt rivers, and the River Maas.

Decoys are also worked all round the Zuyder Zee, as well as on the inland meres that are within a few miles of this great inland sea.

The Decoys in Holland are very much the same as are ours in shape and accessories, though more primitive in their construction and manner of working.

Fï.s. 1.

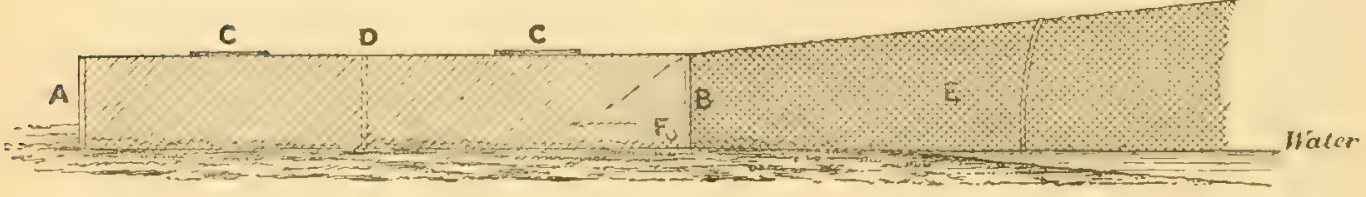

livg. II.
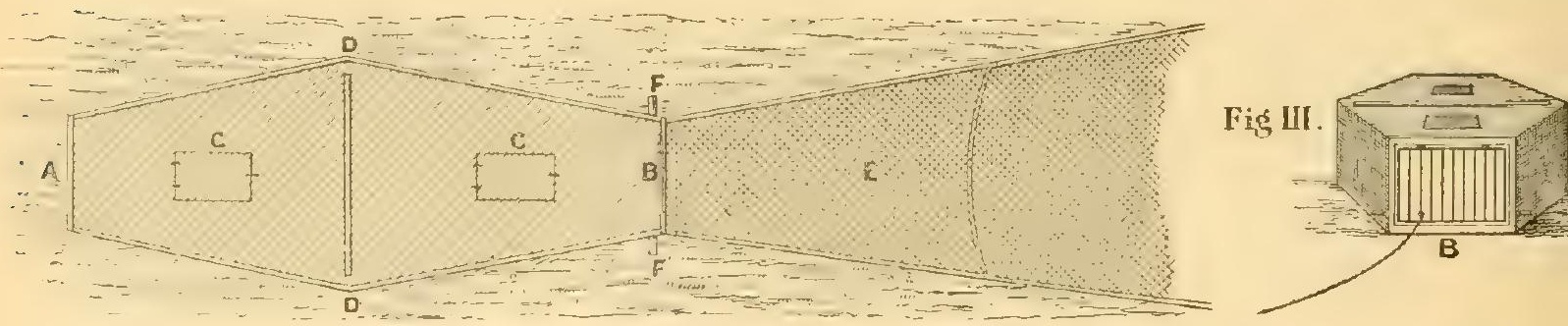

TRAP AT END OF DUTCH DECOY PIPE.

In lieu of having a serics of short screens placed along the sides of the Decoy pipes, it is the custom to have one or two long screens instead.

The fowler instead of following up along the pipe at the back of the screens with his dog, and when he has the birds far enough under the net, running back to the pipe's mouth to cut them off, acts differently.

He in preference waits well concealed near the pipe's mouth and sends his dogr up the sides of the pipe by himself all along the front of the one or two long screens which I have alluded to.

On the fowl rushing up after the dog, the Fowler, when he sees through his peephole they are far enough uncler the net to be caught, suddenly 
springs into view, and so urges the forvl intu the trap at the end of the pipe.

This trap, which does duty for a tunnel net, consists of a wooden box some soft. in length, which I here give a sketch of, and by means of which the birds caught are kept alive, if (as is often the case) they are so required by the dealers.

At $A$, the furthest end of the trap from the pipe, is a fixed railing which the birds can see between on entering the trap, and which they endiavour to reach under the idea they can push thrumg it and so escape. At 13 (Figs. I., II., III.) there is also a railing. but it is makle in the form of a swing cloor that opens inwards only, and which, when a catch is about to be made, is lightly propped open.

On reaching the door, and seeing through the trap, the hurrying frightened birds press into the latter; once insicle they cannot escape, for the door is pulled back asain into a rertical position ly means of a string, and no pushing will open it from inside.

$\mathrm{C}, \mathrm{C}$, are the small shutters which are removed by the Decoyman when taking out the captured birds.

D, D, is a partition of open framework, and which enables the Decoyman to separate his captives, or have one-half of the trap clear of birels for another catch.

$\mathrm{E}, \mathrm{E}$, the end of the Decoy pipe.

F, F, small pegs for safely securing the swing door at night when birds are caught.

Fig. III shows the long cord which the Decoyman uses to pull dowr. tight the door as soon as he sees fowl are entrapted, and one end of which he holds in his hand.

The Dutch Decoymen, who, I may adcl, clo a very large tracle in live birds with Enyland and the Continent, are by this mons enabled to take the fowl alive with the least possible trouble, and risk of clamaging them.

The shutters for taking the birds out as required are a necessity, for it is the custom of the Decoymen to pretty well fill the extreme encl of the trap with birds, the result perhaps of several drives on consecutive days, before taking his unfortunate captives out to send them away.

The Decoy pipes do not usually have arched hoops, but insteal, poles 
erected each side of the ditch over which netting is stretched so as to form a square roofed Decoy pipe.

I remarked a curious device worth mentioning by which the Dutch Decoymen protect the tame Decoy Duclis in the laying season from the attacks of foxes, cats, and other encmies. They fix to the branches or trunks of the trees in the Decoy wood, $6 \mathrm{ft}$. or so above ground, neat smooth baskets made of reed or straw.

A sketch of one of these contrivances I here give.

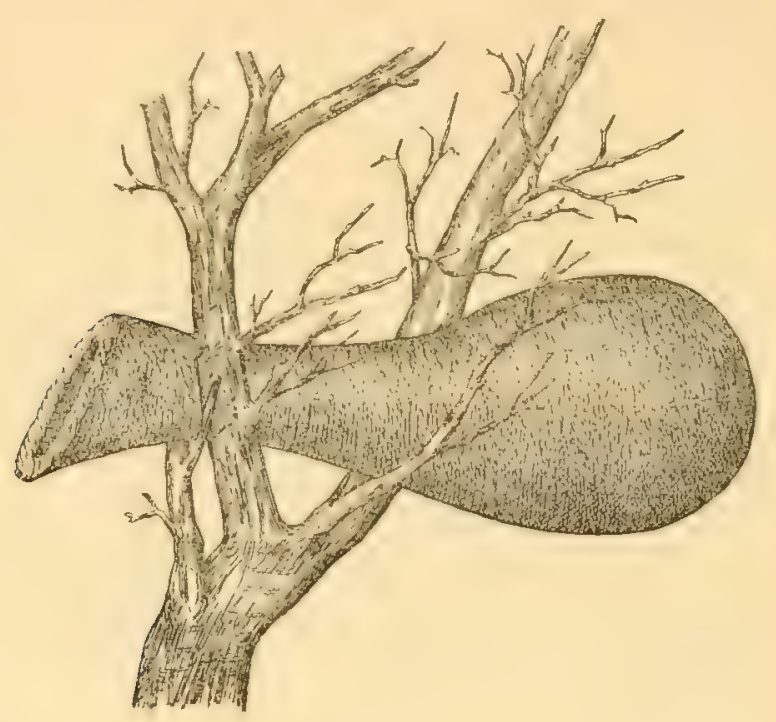

The Decoy birds fly in, line the inside of the basket with down, lay their eggs and bring their young out in safety.

After a few days the baskets are taken down and kept as shelters for both young and old in a wired enclosure, and not put up on the trees again till the following nesting season. 


\section{A List of Dutci Decoys known to the Author.}

Zoutkamp, in the province of Groningen on the western side of the

\section{Lauwers Zee.}

There is a very good Decoy here with + pipes, within a quarter of a mile of the town of Zoutkamp, which latter has come into existence since the Decoy was made, but notwithstanding its proximity, the Decoy is a lucrative one and takes from three to four thousand fowl annually.

The Author remarked that here, as in many other instances, the Decoyman's cottage stool in the Decoy grounds and within 60 yards of the pool, one of the pipes twisting up to the very door of the house itself.

Nicrhuisen, a couple of miles North of the last named on the same shore of the Lauwers Zee are two more Decoys similar to that at Zout. kamp.

Tibnia in Friesland. Two miles north of Dockhumer-Zyl. There are two Decoys here on the W. bank of the Lauwers Zee just opposite to Zoutkamp. To the Author's knowledge these two pools caught 1,000 fowl apiece in one week in the early part of November in the year r 8. 4 .

Schiemonikong. This island which lies opposite the entrance to the Lauwers Zee and forms one of the South Frisian chain, has a large Decoy on it.

Terschelling. Another island, one of the South Frisian, has a Decoy on it with 6 pipes.

Near Emden, a town in the province of Schleswig, on the North shore of the Dollart estuary, are two Decoys attached to a lake.

Föhr. The largest island of the North Frisian group. It lies NW. of Husum off the coast of Schleswig. There are six Decoys on this island, five of which are managed by a company. Their collectire average take is from 40,000 to 50,000 willfowl in a season. In I $88,3-4$ they accounted for over 50,000 fowl. All this portion of the const of North Germany is densely frequented hy I uck, Wigeon, and Teal in the months of October and Norember, but on the arrival of frost the birds disperse southwards. 
The Decoys of Föhr, as well as those on the neighbouring islands next alluded to, are surrounded for many miles by vast ooze banks which support and attract myriads of Duck, Teal, and Wigeon.

The Decoys are kept very quiet, and shooting afloat is by law very strictly forbidden on this coast in the interests of the numerous Decoys.

Ammm. Another North Frisian Island that possesses a large Decoy, one in which 1,500 duck, chiefly Pintail, were a few years since taken in a single day.

Sylt. Belonging to the same group of islands has two Decoys.

Fanф, also possessing one.

In connection with the Decoys and wildfowl of Holland I append the following very interesting notes kindly supplied to me by Mr. Cavendish Taylor. This gentleman, an enthusiastic naturalist and sportsman, has travelled in Holland considerably, and tells me that the information given below may be fully relied on, as it was carefully collected and analized at the time it was compiled, a few years ago.

Mr. Taylor says, "Mr. Van Heclin is one of the largest exporters of Dutch produce in Holland.

He owns Decoys himself and contracts with the owners of 70 others to talie all their birds at a fixed price. These he sends principally to London and Paris. His residence is in Dordrecht where the birds are sent to him from the Decoys. There he packs them in osier baskets, and, if destined for England, ships them from Rotterdam.

He gets birds from many Decoys in Friesland. These latter are not sent to Dordrecht, but are shipped from Harlingen.

The contract price with the Decoy owners is about Is. $4 \mathrm{~d}$. apiece for Ducks. But wildfowl are valued according to the following scale, viz. :-
2 Wigeon
2 Shovellers.
3 Teal.
I Pintail and I Teal

I Duck

Gadwall are not numerous and not of much account. Teal are always plentiful and in demand. 
Mr. Van Heckn has shipped 33,000 ducks (according to the above scale representing 50,000 birds) from Friesland alone in a season, and fully double the number from Dordrecht.

He has sent off 800 woodcock in a week. These were from Drenthé and were caught in nets. He also gets snipes in numbers from near Saardam in North Holland; also solden Plover, on one occasion he sent away from Friesland 26,000 of the latter birds in a week.

Wild Geese are not in demand, but Mr. Van Heckn often deals in Bitterns.

There is a great difference in the seasons. Frost is bad, as it drives the birds out of the country.

Wet winters are most productive.

The Decoy season commences in August and ends the last day of March.

The early season is mostly for Teal and homebred birds, but these are at that time not very saleable having to compete with Game in the markets.

In Paris during Lent there is a good sale for what are termed blue legged Wildfowl, such as Scaup, Tufted I uck and other divers, these being regarded by Catholics as being of such fishy flavour that they are allowed to be used as food in fasts.

In Holland there are both sea coast as well as inland Decoys. The latter do best in wet, and the former in dry weather, when there are no inundations.

Mr. Van Heckn's Decoy is a sea Decoy, it is (or was) situated on the Island of Rosenburg at the mouth of the Maas. The Island is $I, \equiv 00$ acres in extent, mostly pasture, excepting the $I_{4}$ acres of osiers in which the Decoy pool is placed. For the Decoy a rent of $\delta_{6} 6$ a year is paid, but the lessee also rents the shooting over the contire island for the purpose of keeping off intruders with guns.

The Decoy is a large one with 6 pipes and caught 7,000 fowl the season Mr. C. Taylor inspected it. Mr. Taylor tells me that he paid a visit to Mr. Van Heckn's menage, where he packs and ships the birds, and saw about 300 live wildfowl, consisting of ITigenn, 'Teal, Garsaney, l'intails, Tufted Ducks and Colden liyes, hesides a number of Brent Geese all ready to be sent off to London. The birds were 
kept in pens on dry straw, with but little water, and were fed with buckwheat and canary seed. Mr. Van Heckin formerly bred Carolina and Mandarin Ducks, but gave it up as being too troublesome. The latter birds were however, Mr. Taylor was informed, very easy to rear, as easy as chickens, provided ants eggs could be procured for them.

\section{Decoys in France.}

Though I have frequently heard Decoys alluded to as existing in France, yet I have never been able to obtain any reliable information thereon.

Samuel Maunder in his "Treasury of Natural History," published in I 846 , concludes a long and fairly accurate description of Duck Decoys as follows :-

"In Picardy in France vast numbers of Ducks are taken in Decoys and sold in the Paris market, where in one season 30,000 francs have been paid for the produce of the small lake of St. Lambert." 


\section{N D E X.}

A.

\section{Abbotsbury Castle Decoy, 7 I}

Acle Decoy, 139

A Decoy in the Days of Queen Anne, 80

Aldermaston Park Decoy, 60

Aldingboume, I $7 \mathrm{I}$

Aldwinckle Decoy, I42

Alford, Richard, 124

Allen's History of Yorkshire (I\$29), 184

Aller Decoy, I58

Alston, Mr., 78

American pond weed (Anzcharis alsinastrum), I38

Anamoe Decoy, 196

Angmering Decoy, 172

Annis, Abraham, 9I

Arnold, Rev. Coope, 84

Arundel Castle, 172

Ashby (Lincolnshire) Decoy, I16, II9

- (Suffolk) Decoy, 165

Ashwell Fen, 65

Aslackby Decoy, I2I

Aston Hall Decoy, 150

Aubeg, River, IgI

Aubrey, Sir John, 6I

Austin, Mr., I 57

Avocet's Nest found $18+0,186$

Axholme, Isle of, 68, 104, 185

Aylesford, Earl of, 174

B.

Back Screens, Length of, 32

Bacon's Farm, 87

"Bailiff of Marshland," The, II3

Ballynakill Decoy, I92

Baren, Mr. Laurence J., $\$ 70$

Bate-Dudley, The Rev., 78
Bateman, Lord, 95

Bath, Marquis of, I54

Beaulieu (Hampshire), 95

(Louth) Decoy, 193

Beda taken prisoner by Hereward, 108

Bedford, Earl of, 68

- Level, The, 66

Level Scheme, 4

William Earl of, 68

Bell, William, r 23

Benacre Decoy, 167

Benedictine Monastery of Wix, 92

Berkeley Castle, 93

-- Decoys, Gloucestershire, facins 93

Besthorpe Decoy, 139

Beverley, 183

"— and Barmiston Drainage Act of 1798," i $8 \mathrm{i}$

Birch, Mr. WVyrley, 132

Birdcage WValk, 128

Birds caught in Dowsby Decoy from October, 1765 , to April, 1766,120

- caught in Iken Decoy from 1878 to 188 ; 162

- caught at Orielton Decoy, 149

- taken in Ashby (Lincolnshire) Decoy from I 833 to 1868,118

Birdsall Decoy, 187

Bixley Decoy, 164

Blackburne, Col. J., M.P., roo

Black-headed Gull (Larus ridibundus), I86

Blackwater River, 75

Block Fen, ${ }_{5}$

Bluehouse Farm, 92

Blunt Fen, 65

Boarstall, Cottage at, 62

… I)ecoy, 6I

- - Manor of, $6 \mathrm{t}$

Bohun's Hall Decoy, 86

Lordenweare, I57 


\section{Borough Fen Decoy, I43}

Bourne Decoy, I19

Fen, 103

Bournemouth Decoy, 95

Bowen's Map of Essex, 1760, 84

Boyes, Mr. F., 184

Bradwell Marsh, 76

Bradwell-juxta-Mare, 79

Brantham Decoy, 168

Breast-wall Screens, 44, 45

Brent Marsh, 156

Brill Hills, 62

Bookesby, Rev. Francis, I 84

Broke-Middleton, Sir George, I64

Broughton Decoy, 125

Buckinghamshire, Decoys in, 60

Buckingham, Duke of, 64

Burton Hall Decoy, 124

Butterbump Hall, I8I

\section{C.}

Cage Decoy, The, 3

Caledon House Decoy, 195

-

Caldicott Level, I29

Call Ducks, 47

Calthorpe, Lord, 139

Cambridgeshire, Decoys in, 65

Camden, 5

Campsey Ash Abbey, I68

- Decoy, I68

Canney Marsh, 79

Capel, John, 64

Carolina Ducks, 204

Carrington \%. Taylor, 17

Cat, Ferret, and Rabbit as Decoys, 49

Catching Birds in Decoy Pipes, 21

Cavendish Taylor, Mr., 202

Cawston Decoy, 136

Caxton, Cambridgeshire, II I

Chadwick, Major R., I 88

Charborough Park, 73, 74

Charles I., 68

Charles II., 3, 126, 128

Chatteris Decoy, 66

Cheddar Water Decoy, 159

Chesil Beach, 73

Chillesford Decoy, I6z

Chillington Decoy, 160

Clare, Earl of, 145

Claydon House Decoy, 64

Cloncurry, Lord, 193
Clonfert Decoy, I92

Clumber, 143

Coatham Decoy, i7s

Cobb's Farm, 84

Cockett Wick Farm, 88

Colebrooke, Sir Thomas, I70

Cockswere, I 57

Colman, Mr. J. J.- " Life of a Fenman," I Io

Coloured Cloth round Dog, 49

Colquhoun, Mr. J., I 88

Combe Abbey Decoy, I74

- Decoy, Warwickshire, facing 174

Compton Dundon Decoy, I 57

Concealed Path, 32

Construction of a Decoy-pipe, 35

—— the Hoops, 36

Cooper, Colonel E. H., 195

- Mr. 63

Cordeaux, Mr. J., II 7

Cork, County of, Decoys in, 190

Cornwall, Decoys in, 70

Coventry, the late Mr., 74

Cowbit Decoy, 120

- Fen, 103

"Coy," The word, 3

Cracknell, Mr., 77

Cranmore Fen, 65

Craven, Earl of, 174

Crossley, Sir Savile, I65

Crouch, River, 75

Crowland, Abbot's Decoy at, 4

Cunningham's "Handbook of London," I26

Curiosity of Wild Ducks, 23

D.

Dacre, Lord, 97

Daniel's "Rural Sports," 4, 78, 120

Dawson, Mr. G. P., I8o

Decoy, Derivation of the Word, 2

- Pond, The, 40 Old Engraving of, 9

Decoying, 2 I

Decoying with a Dog, 23

- with Food, 27

Decoyman's Assistant, 33

Decoymen, I

Decoys are protected by Common Law, I 4

- have no special Act, I4

- - in France, 204

Decoys in Holland, 197

East Frisian Islands, 198

Flushing, 198 
Decoys in Holland (continued).

Friesland, 197

Groningen, 198

North Brabant, I98

River Mlaas, I98

River Scheldt, 198

Rotterdam, I98

Schleswig, 197

Utrecht, I98

Zuyder Zee, igs

Decoys, Rights of, I5

Deeping Fen, 5, 103

- Fen Decoys, II9

Deerhyde, 6I

Derby, Countess of, I 7 I

Derbyshire, Decoys in, 70

Dersingham Decoy, 135

Desart, Earl of, 193

House Decoy, I93

Description of a Decoy-pipe, 57

Didlington Decoy, I 33, I 34

Ditch of a Decoy-pipe, 35

Dog, The, 48

"Dog and Duck" Inn, I87

Dog-jumps, 44

Donelly's "Tour in Ireland," 194

Doneraile Court Decoy, 191

- Park, $19 \mathrm{r}$

- Viscount, I9I

Dorsetshire, Decoys in, $7 \mathrm{I}$

Dorton House, 6 I

Dovercourt Decoy, 91

Down, County of, Decoys in, I9I

Downham Fen, 65

- Market, 140

Dowsby Decoy, I20

Dowse, 1 homas, 123

Drayton's "Polyolbion," I09

Driving the Birds up the Pipe both when Dogging and Feeding, 3 I

Wildfowl, 5

Wildfowl in the Sixteenth Century, 6

- Wildfowl up the Pipe, facing 34

Drop of the Hoops, 38

Duck Cage, The, 3

- and Teal taken with the Dog, 29

Duff, Colonel, 132

Dugdale, 105, 106, 108

Durham, MIr., I 87

Dutch Decoymen, I99

Decoy Pipe, Trap at end of, 198

Decoys known to the Author, 20I

Amrum, 202

Fan $\phi, 202$
Dutch Decoys known to the Author (continued).

Föhr, 20r

Nierhuisen, 20I

Schiermonnikoog, 201

Sylt, 202

'Terschelling, 201

Tibnia, 201

Zoutkamp, 20 I

Dutch Nesting Basket, 200

Dynham Family, 6r

- Sir John, 147

E.

Eardley, Lord, 143

Earith, 96

East Fen, 103, 105

— Hall Decoy, 79

Eau-brink Canal, I12

Edward VI., Act of, against taking Eggs of Wildfow 1,6

Effect of the Dog on the Ducks, 29

Ellenborough, Lord, 8s

Ely, Isle of, 67, 108

"Endekooy," Word, 3

Enticing Wildfowl up Decoy-pipe by Dog, facing, 26

Entrance to Decoy-pipe, with Dog at Work, facing 30

-.._ a Decoy-pipe, 37

Escrick Decoy, Yorkshirc, 179

- Park Decoys, 179

Essex, Decoys in, 75

Evelyn's "Diary," 3, 127

Evelyn on St. James's Park Decoy, 126

Everdell, Joseph, 155

Eyre Court Decoy, I92

F.

Farcett Fen, 96

Farlsthorpe Decoy, 124

Fellowes, Mr., I 39

Fen Slodgers, II 3

Fenman, Outdoor Occupations of, i i 5

Fenmen, The, 104

Fen-Parson, The, I Io

Fifteen Hundred Ducks taken in a Day, 202

Fifteen Thousand Fowl taken in one Season, 167

Findhorn Bay, 188 
Firle Decoy, 17 I

$$
\text { Park, } 17 \text { I }
$$

Fiske, John, 90, 164

Fitzhardinge, Earl, 93

Fitzgerald, James, 194

Fleet Decoy, 120

- Estuary, 71, 73

Flixton Decoy, 168

Fodder, 105

Food, The, used in a Decoy, 50

Acorns, 50

Barley, 50

Bruised Oats, 50

Buckwheat, 50

Canary Seed, 50

Hemp Seed, 50

Hemp Seed Oil sprinkled on Oats, 50

Malt-grains, or Coombs, flavoured with Aniseed, 50

Maize, 50

Wheat, 50

"Willow-weed" (Polygonum persicaria), 50

Footfalls, Safeguard against Sound of, 45

Forest of Bernwode, 61, 62

Foster, Barcn, 193

- Rev. Thomas, 120

Fountaine, Mr. A., I32

- Rev. John, I32, I33, I 39

- Mr. E., I67

"Fowler in Ireland," I9o

Fox's Skin on Dog, 49

Foxes in Decoys, 24

Framework of a Screen, 46

Frequent Error made in Decoys, A, 33

Friskney Decoy, Lincolnshire, facing $\mathbb{2} 22$

- New Decoy, 122

- . Marshes, 122

Friston Decoy, 168

Fritton Decoy, 164

Front of a Scrèen, 46

Fullager's Decoy, 98

Fuller's "Worthies of England," I07

G.

Gadwall, The, 132

Gage, Viscount, I7 I

Galway, County of, Decoys in, 192

Gardener's Farm House, 84

Gascoyne, Mr. W.-Account of Grovehurst Decoy, 98

Gedney Marsh, I03
General Directions for managing Decoy and catching Ducks, 5 I

Best time to try, 53

Boat, 54

Casting Shadows, 53

Ice, Clearing Decoy of, 54

Killing Birds, 54

On approaching a Decoy, 52

"Rising" a Decoy, 54

Securing Live Birds, 55

Smouldering Turf, $5 \mathrm{I}$

Weathercock, A, 5 I

Wind, 5 I

General Drainage Act, 68

Giffard, Mr. W., 160

Gilby, Colonel Anthony, 184

Glamorganshire, Decoys in, 93

Glaston, John de, 156

Glastonbury, Abbey of-Survey of Temporalities, 157

Glastonbury, Abbot of, 153

Glebeland Decoy, 78

Gloucestershire, Decoys in, 93

Glynde Decoy, 173, 193

Godney Decoy, 158

Goldhanger Decoy (I), 84 , , (2), \&4

Gooch, Sir Francis, 167

- Sir Alfred, 168

Goodwyns, The, 63

Goole Moors, is6

- New Decoy, I87

Old Decoy, 187

Gore Decoy, 85

Gough, 5, 6

Great Bedford Level, The, 68, 69

- Cotes Decoy, I25

_ Oakley Hall Decoy, 88

Greene, Thomas, 126

Grovehurst Decoy, 98

Gunton Park Decoy, 136

H.

Habitues of the Decoy, 49

Hachemere, I 57

Hagnaby Decoy, 123

Hale Decoy, roo

Hall, William (alias "Antiquarian Hall," \&c, \&c.), 113

Halnaker House, I7 I

Halton, Lake at, 60

Hamford Water, 75 
Hampden, Viscount, 173

Hampshire, 94

Hampworth Decoy, 175

Hanbury, Mrs. F. S., I 43

Handlo, Sir John de, 6r

Hardwick Hall Decoy, 70

Hare, Sir Thomas, I 40

Harland, Sir Robert, 163

Harting, Mr. J. E., 79

Hartington, Lord, 70

Hatfield Chase, 68, 107

Haughton Decoy, I 44

Hawkshaw, 68

Head Hoop, Height of, 36

Healy, Captain, II7

Heathcote, Mr. J. M., 97

Hemsby Decoy, 138

Hempstead Decoy, 137

Henry VII. (tcmpo), 157

—VIII. (tempo), 157

VIII., Act of, against taking IVildfowl with Nets, \&c., 6

Herefordshire, Decoys in, 95

Heron pursued by a Peregrine, 149

- Court, 74

Herringfleet Decoy, I6+

"Hertford and Derwent Drainage Act," 176

Hertfordshire, Decoys in, 97

Hervey, Lord A., I78

Heywood, Mr., 162

Hickley, Admiral, I55

Higford Burr, Mr., 60

Hilcus, Sydrach, 3, 127

Hilgay Decoy, I40

"History of Somersetshire," I 56, I 59

"History of Whittington Castle," Lines from, I 51

Hockwold Decoy, I4I

Holbeach Marsh, 103

Holderness Fens, I76

Holkham Decoy, I 36

— Lake, 136

Holland Fen, 103

Holme Decoy, 184

- Fen, 96

Holt, Lord, 14

Hood, Sir Alexander, 158

Hoop-ends, Sinking of, 37

Hoplins, Captain, 123

Hornby Castle, 177

-Decoy, Yorkshire, facing 93

- Decoy, 177

Horsey Island Decoy, 91

Hotham, Sir Charles, I8I
How to Cut the Ditch of a Decoy-pipe, facing 36

How Decoyman gets behind Birds in the Pipe, 32

Hudson, Mr., 77

Hull, River, I76

Hume, Mr. Joseph, M.P., I37, 172

Huntingdon, Mr., II, I37

Huntingdonshire, 96

Hussey-Vivian, Sir H., 93

Hutchins' "History of Dorset," 71

I.

Ice, Formation of, at Pipe's Mouth, 41

Iken Decoy, 162

Ilchester, Earl of, 7 1, 157

Ireland, Decoys in, 189

J.

Jackson, Rev. F. (of Wisbeach), 66

Jacques Hall Decoy, 92

Johnson, Sir J. H., 88

K.

Keadby Decoy, 125

Kebbell, Mr., 78

Kedgers, II I

Keeble $v$. Hickeringall, 16

Kemsley Decoy, I0o

Kent, 98

Kenn Moor Decoy, I 59, 160

Kerrison, Mr. John, I3s

Kilcooley Abbey Decoy, 195

Kilcoursie, Lord, 153

Kildare, County of, Decoys in, 192

Kilkenny, County of, Decoys in, 193

King John, 4

King's Sedgemoor, I 52

$\longrightarrow$ Decoys, 154

Kirkleatham Hall, i 78

"Kooy," word, 3

Kyme Fen, IO3

L.

Lancashire, Decoys in, 100

Laddus Fen, 65

Lakenheath Decoy, 167 
Lakenheath Decoy, Suffolk, facing 167

- Fen, I6I

Landings and Banks of Decoy Pond, 4I

Langham Decoy, I 36

Lacthington Decoy, 84

Laver, Dr., 84

Leake Decoy, I 24

Leathes, Colonel, 89,164

Leeds, Duke of, 14, 134, I77

Leicester, Earl of, 136

Leland's "I tinerary," I 56, I 84

Le Serre on St. James's Park in 1633, 127

Leverington Decoy, 65

Lichelake, 157

Lilford, Lord, 142

Limerick, County of, Decoys in, 194

Lincoln, 103

- Earl of, I 43

Lincolnshire, Decoys in, 103

Lion Point Decoy, 88

Lipscombe, 62

Lismullen Decoy, 194

Lisrenny Decoy, 193

List of Decoys in the British Islands-Past and Present, 59

Liver-coloured Fox-terriers, 90

Lloyd, Colonel R., I 50

Richard Savage, I 8 I

London Carriers, III

Longfield, Richard, 190

Longueville Decoys, 190

Lonsdale, Earl of, 175

Lough Beg Decoy, I9I

- Derg, 192

Neagh, I92

Louth, County of, Decoys in, 193

Lovelace, Lord, I70

Lowther Castle Decoy, 175

Lubbock's "Fauna of Norfolk," 137

Lubbock, Rev. Richard, I 38

Lymore Hall Decoy, I29

Lynn Market Place under Water, I04

Lyons Decoy, 193

M.

Maclean, Dr., on Malaria, II2

Maidens, Daniel, 123

Malmesbury, Lord, 95

Man who kills the Ducks outside the Decoys, 16

Mandarin Ducks, 204
Markree Castle Decoy, 195

Marlborough, Duke of, 62,63

Marryat, Captain, R.N., the late, 136

Marsh House Decoy, 76

Martineau's (H.), "Settlers at Home," 107

Mascail, Mr., 78

Maunder's "Treasury of Natural History," 204

Mautby Decoy, I39

Maybanke, Edward, I 26

Meare Decoy, I 56

- Pool, 156

Meath, County of, Decoys in, 194

Meaux Abbey, 182

- Decoy, I80

Menzies, Mr., I69

Merry, Mrs., 90

Mersea Island, or West Mersea Decoy, 87

Mersey, The, Ioz

Merton Decoy, I 35

- Hall, 135

Methods used to Decoy Ducks into Pipe, 22

Methwold Decoy, I 40

"Mickle Mere," 132

Middle Fen, 65

- Level, 70

— Moor, 96

Middlesex, Decoys in, 126

Middleton, Lord, I 46, 187

Mildenhall, 167

Milford Haven, 149

Millyard Farm Decoy, 12 I

Monaghan, County of, Decoys in, 194

Monastery of St. Frideswide, 63

- of St. Peter, 7 I

Monkey in a Decoy, 49

Monmouthshire, Decoys in, 129

Monson, Lord, I24

Montefiore, Mr., I73

Montgomeryshire, Decoys in, I 29

Mordon Decoy, 73

Morris Fen, 65

- Mr., I 33

Morrison, Mr. G., 175

Morse Family, The, I68

Morton, Bishop of Ely, 67

Mosslands, 102

Moulton Marsh, 103

Mount Louise Decoy, 194

Mountainstown Decoy, 194

Muswell Hill, 62

Mytton, Jack, I 5 I 
N.

Nacton Decoys, 164

Narford Hall Decoy, I39

Nash Decoy, I29

Nene, River, 142

Netting of a Decoy Pipe, The, 35

Newcastle, Duke of, 144

Newcomen, Mr. A. H. T., I7S

"New Critical Review," I27

New Forest Decoy, 95

Newfoundland Dog, as Decoy, 50

Newstead, 144

New Zealand (Yorks.) Decoy, I 87

Nigel, the Forester of Bernwode, 6r

Nocton Hall Decoy, I2I

Norfolk Broads, The, Iog

Norfolk, Decoys in, I30

Norfolk, Duke of, 172

Northamptonshire, Decoys in, 342

North Fen, 65

North Kyme Decoy, I2I

North Level, 70

North Stoneham Decoy, 94

Northumberland, Earl of, Is 3

"Northumberland Household Book," 18:

Nottinghamshire, Decoys in, I43

Nyland Decoy, 159

- Hill, I59

O.

Oakley Park Decoy, 150

Object of Decoyman, 21

Oldfield's " History of Wainfleet," 123

" old George Skelton," I2

- Hall Decoy (2), 86, 87 Mill Creek, 86 Mose Hall Decoy, 88

"Old Tom Williams's Decoy," 124

One Night s Decoying, Result of, 166

One-pipe Decoy, 56

Openings betwcen the Sicreens, 45

Orford Hall Decoy, 102

Orielton Decoy, 147

Oriel Decoy, I 93

Origin and Age of Decoys, 3

Orford Haven, 163

Orwell Park Decoy, I63

- River, 163

Osgodby Hall Decoy, 1 So

Ossington Hall Decoy, 145
Otmoor, 60, 62

Ottershaw Park Decoy, 170

Oundle, I42

Ouse, River, II 2

Oxfordshire, Decoys in, 146

P

Packington Hall Decoy, 174

Page, Mr. Charles (Grange Farm), 7 S

- Mr. R. (Marsh House), 77

Paling, necessary to Decoy, 43

Park Hall Decoy, I 45

- - Wern Decoy, 93

l'arteene Decoy, 194

Pearce, Rev. F., 74

Peasmarsh Decoy, 173

Pedley's "Fens and Floods of Mid-Lincolnshire," 104

Peep-holes in Decoy screens, 44

Pembroke, Earl of, 146

Pembrokeshire, Decoys in $1+7$

Pennant, $12 S$

—_ records great Catch of Ducks, II

Pepys' "Diary," 127

Perry, River, I 50

Petre, Mr. J. Berney, I 3 I

- Mrs., I 32

Pevensey Marsh, I7 I

Pewit Island, 88

Phelps" "History of Somerset," 160

Phraseology of a Decoy, 17

Breast-wall, I7

Decoy Ducks, is

Dog-jumps, is

Draught of a Pipe, 17

Food, I8

Head Shew, 17

Hoops, I7

Landing-places, 18

Pipes, I7

Reed Edges, 17

Screens, I7

Tunnel-net, is

Turf, Is

Yackoop, The, I 8,26

Picardy sends large Numbers of Ducks to Paris Market, 204

Pinchbeck Fens, 103

Plan of a Pipe, 57

Plan of Three-pipe Decoy, facing 55

— of Decoy-pipe, fucing 57 of Five-pipe Decoy, facing 58 
Plan of Cage Decoy, facing 71

- - - 72

Plans of Decoys, Criticism of, 55

Plumb, James, 132

Pochards, 77

Pochard Ponds, 84

Pond Hall Decoy, 92

Ponsonby, Mr. C. B., 195

Poole Harbour Estuary, 74

Position of Decoys of the British Islands, ro

Posts of the Screens, 45

Powis, Earl of, 129

Prescott, Sir G., 86

Price paid for Wildfowl in 1716,82

Price, Sir Rose, 70

Privet, on Bank Tops, 42, 43

Protection of Wildfowl, 6

Pug, as Decoy, 49

Purdis Hall Decoy, 164

Pyrford Decoy, I70

R.

Rabbits a great Nuisance, 43

Ramsey Abbey, 108

— Island Decoy, 79

Mere, 69, 96

Kanworth Broad, 138

- Decoy, I3s

Rathescar Decoy, 193

Ratton Decoy, 173

Ray, 4

Rear of a Screen, 46

"Redfurns," The, I07

Redmore Fen, I4I

Reed Edge around the Water of a Decoy, 42

Reeds, The, 46

Rennie, 68

Ricketts, C. Aubrey, 6i

Ridge-trees, 37

Ridsdale, Rev. Mr., I70

Rimes, James, I 26

Ripon, Marquis of, I 2 I

River Nen, 65

Rother, River, 174

Rothschild, Baron Ferdinand de, 62

Roydon Hall Decoy, 92

Russell, Colonel, 84
S.

Salmon, Mr. Joseph, 88

Salter, Dr. J. H., 86

Saurin, Colonel, I47

Sawdust strewn along Path, 45

Scorborough Decoy, I 84

Scotland, I88

Scott, Lord Henry, 95

- John, 127

Screens, The, 44

- Construction of, 46

Screen-posts, 44

Sedge Fen, 65, 167

Sempringham Fen, 103

Setting up the Hoops, 37

Severn, River, 93

Shannon, River, 194

Shapwick Decoy, 154

Shardeloes, Lake at, 60

Sharpe (Gamekeeper), I49

Sharpham Park Decoy, 153

- and Sedgemoor Decoys, Somerset, facing 93

Sheep depastured in Wildmore Fen, 105

Shobdon Court Decoy, 95

Shooting round a Decoy, 133

Shores of Decoy, 4 I

Shropshire, Decoys in, I 50

Simpson, Mr. George, 88

Sittingbourne Decoy, 98

"Six Hundred Decoy," The, I 14

Skellingthorpe Decoy, I 24

Skelton, George, II, I35

- Death of, 13

- Henry, I 3

John, 122

- Old George, Portrait of-Frontispiece

$-\frac{}{-}, 179$

- Richard, 12

-_- T. Gilbert, 12, I 49, 195

William, i2, 174, 195

Skeltons, The family of, 12

Skinner's Wick, or Whitehouse Decoy, 85

Sligo, County of, 195

Smith, Mr. James, 89

Snipe, Large numbers of, I7 I

Solley's Decoy, 85

Somersetshire, Decoys in, 152

Souley Pond, 95

South Acre Decoy, I 4, I32

- Carlton Decoy, 124

Hall Decoy, 79 
South Kelsey Decoy, 124

\section{- Kyme Decoy, 121} Level, 70

Southwell, Mr. Thomas, F.Z.S., 105,130

Spalding, 3,000 Mallards at one Drive, 4 Moor, 184

Spalford, Dykes near, Io4

Spelman, Sir Henry, 2

Spiller, Sir Robert, I47

Staffordshire, Decoys in, 160

Stale Birds, 49

Stansgate Wick, 79

Steeple Decoy, 79

St. Catherine's Chapel, 7 I

Steeple Creek, 79

St. Giles' Fen, 65

St. James's Park Decoy, I26

Stilton Fen, 96

Stoke Decoy, I 59

Stoneham Park, 94

Stonehurst's "Hist, and Topog. of the Isle of Axholme," 117

Storey, Edward, I 26

Storey's Gate, 128

Stour, Estuary of the, 75

Stow Bardolph Decoy, I 40

Stowe, Lake at, 60

St. Paul's, Dean and Chapter of, 76

Strangways Family, 73

Sudbourne Hall, I6z

Suffield, Lord, I37

Suffolk, Decoys in, I6I

Sundorne Castle Decoy, $15 \mathrm{c}$

Sunk Island Decoy, I 8.4

- State of (17I1), 184

Surrey, Decoys in, 169

Sussex, Decoys in, I7 I

Sutton Fen, 65

Swannery (Abbotsbury), 71

Swans on the Fleet, 73

T.

Tacey, Mr. George, in

Taking Birds out of Tunnel-net, 22

Tame Decoys, 27

-. Decoy Ducks, 47

Tame-reared Wild Ducks, 48

Tangmere Decoy, I7I

Tees Bay, 179

Tetford, 68

Thame, Neighbourhood of, 60

Thames, The, 127
The Great Fen, 96

The Grange Decoy, Tillingham Marsh, 78

The Hoo Decoy, 97

The Old Decoy, or Jacques Hall Old Decoy, 9?

"The Severals," I 40

Thirkleby Park Decoy, 178

Thomas, Mr. F., 173

Thompson's "Natural History of Ireland" (1851), 190, 191, 192, 193, 194, 196

Thoresby, 144

Thorne Waste, 186

- Decoy, 185

Thorney Fen, 65

Tillingham Marsh, 76, 78

Timberland Decoy, I2 I

Tipperary, County of, Decoys in, 195

Tolleshunt D'Arcy, 85

Tomline, Col. George, I63

Ton of Ducks, A, despatched twice a week, 167

Tor, The, 152

Tortington Decoy, 173

Trengwainton Decoy, 70

Trundle Mere, 96

Tunnel-net, 39

Two-pipe Decoy, 56

Tyrone, County of, Decoys in, 195

Tyssen-Amherst, Mr., M.P., I 33, 135

Tythrop Decoy, I 46

House, 146

V.

Van Heckn, Mr., 202, 203

Vermin, To protect Decoy from, 43

Vermuyden, Sir Cornelius, 68, 106, 186

Verney, Sir Harry, 64

Villa Farm Decoy, 92

Virginia IVater Decoy, 169

View of a Decoy-pipe from Head Show Place, facing 17

W.

Wainfleet St. Mary's Decoys, 123

Wales, Few Decoys in, II

Wallace, Sir Richard, 162

Walling Fen, 176, 184

Walsingham, Lord, 135

Ward Family of Decoymen, The, I 45

IVarry, Mr. G., I 54

Warwickshire, Decoys in, 174 
Warton, Col. Valentine, 66

Wash, The, 67

Water Supply of a Decoy, 40

Waterman, S*. George, 126

Watson, "History of Wisbeach," 66

Watton Decoy, Yorkshire, I 83

Waxham Decoy, I37

Webb, Mr. G., 100

Webber, Capt. Frank, 196

Welbeck, I44

Wells, Captain, 97

Wells' "History of the Fens," 66

Wenlock, Lord, 179

West Fen, I03

Westbury Decoy, 158

Westmorland, Decoys in, 175

West Wick Decoy, 79, I3I

Westwick House, Norwich, I iI

Wey, River, I7o

Whaplode Fen, 103

Whartons, The, 63

What a Decoy consists of, 18

White Fen, 65

Whittlesey Decoy, 66

-_. Mere, 69, 97, 112

Wicklow, County of, I)ecoys in, 196

Wigeon mainly taken by Feeding, $2 \&$

Wilcrick Decoy, 129

Wild Geese, 64

Wilderness, The (Winchendon) 63

Wildmore Fen, 103, 105

- Tits, I05

Willes, Mr. John, 77

- Mr. R., 78

Willesden, Lake at, 60

William the Conqueror, 108

Williams, Andrew, Lines on, v, I51

- Mr. B., 143

- T., I 40 T. and J., I 24

Willughby (The historian), 4, 6

Wiltshire, Decoys in, 175

Wimblington $\mathrm{Fen}, 65$

Wimborne Decoy, 74

Winchend,n Decoy, 63

- House, 63, 64

Windsor, Lord, I 50

Winslow, 64

Winterton Decoy, I 37

Wire-netting, 38

Wisbeach, 65
Wiseman, Mr., 79

Witham, River, I04

Wodehouse, Sir W., 2

Wolterton Decoy, 136

- Park, 136

Woodbastwick Decoy, 138

Woodhall Decoy, 140

Woolaton Hall Decoy, I46

Wooley, Sir John, 170

Works relating to Decoys, 6

Bewick, 6

Blome, 7

Bradley on Gardening, \&

"British Encyclopædia," Nicholson in, 7

Davics, C., in "Norfolk Rivers and Broads," \&

__ _ "Peter Penniless," 8

"Dictionary of Science and Art," 9

"England Illustrated," \&

Folkard, in the "Wildfowler," 8

Goldsmith, Oliver, 7

"I tinerarium Curiosum," 8

Loudon's "Encyclopædia of Agriculture," 8,9

Lubbock's "Fauna of Norfolk," 8

Maxwell, 8

"Natural History, A," S

Ogilby, John's "Fables of Esop paraphrased," Sketch from, 9

Pennant, 7

Southwell, Thomas, in "Transactions of Norfolk and Norwich Naturalists' Society," \&

"Treasury of Natural History" (Maunder's), 204

Universal Magazine, 7

Yarrell's "British Birds," 8

Wormegay Decoy, 140

Worlingham Decoy, 168

Wormingford Decoy, 92

Worthing, I72

Wotton, Lake at, 60

- Park Decoy, 64

Wrangle Decoys, 123

Wretham Decoy, 132

Wykenham, Mr. P. J. D., 146

Y.

Yew Tree Heath, 95

Yorkshire, 176

Woodfall \& Kinder, Printers, Milford Lane, Strand, London, W.C. 
In One Volume, Sio, 504 pages, with many Illustrations of Foriling Expericuces, Burds, Buats, Guns, and Implements, dran'm by the Aution and Mr. C. WhYMPer, £ I Is.

\section{THE FOWLER

\section{SIR RALPH PAYNE-GALLWEY, Bart.}

\section{OPINIONS OF THE PRESS.}

"He describes wild scenery and exciting scenes with a light and lively pen, nor does he confine himself to the chase of the wildfowl in the bays and estuaries, but treats of many branches of rough inland sport, from shooting woodcock and snipe to catching wild ducks in decoys. The illustrations of episodes of sport are admirably spirited and suggestive."-TIMES, Oct. IO, 1883.

"Mlore particular than 'Folkard's Wildfowler,' and free from the antiquated details of C lonel Hawker's book, this treatise cannot fail to be of service to the sportsman. The first half of this book is so valuable we have not lingered long over the technical details of the other half. Every lover of birds will enjoy the first half of this book." - ATHEN EUM.

"The title of this really beautiful volume is not sufficiently comprehensive, it might justly be styled 'The Complete Wildfowler'; for although the scenes of the Author's fowling exploits lie chiefly in Ireland, the very full instructions which he gives on every point connected with the sport will make it THE book of reference for all who wish to be successful takers of wildfowl." - BAILY'S SPORTING MAGAZINE.

"In this delightful volume the arts of shooting and netting fowl are fully described with the help of plans and drawings. The illustrations are, of their kind, as near perfection as they can well be, those of the various species being equally good with the larger pictures of shooting and trapping exploits."-MORNING POST.

"Since the days of Colonel Hawker we have had no such practical contribution to sporting literature."-GLOBE.

"To Sir Rilph Gallwey fowling is a fascinating pursuit, in which he discovers the birds" secrets hy close, unwearied, patient, yet enthusiastic investigation. The dogged perseverance of years has been rewarded by a success which places him in the front rank of sportsmen-naturalists. It would have been a loss to natural history secords if he had not placed before the public the results of his almost unique experiences of successful fowling."-LAND AND WATER.

"It is a perfect fowler's encyclopredia, practical in treatment and inexhaustible in material, and everything is so admirably finished, text, illustrations, woodcuts, and typography." - IRISH TIMES.

"No more suitable book for a country house can be imagined during the long winter evenings." -ACADEMY.

"This portion of the volume is enriched with portraits of many of the birds named, and we may permit ourselves to say that while there is not a bad one amongst them, those of the Pintail, the Pochard, the Golden-eye, and the Red-Breasted Merganser are decidedly good. Those of the Brent and Bernicle Goose, and especially a beautifully artistic plate of a pair of Great Northern Divers, are of exceptional accuracy and merit."-NORTHERN WHIG.

\section{JOHN VAN VOORST, 1, PATERNOSTER ROW.}




\section{A SELECTION OF \\ BOOKS ON BIRDS AND SPORT, PUBLISHED BY MR. VAN VOORST.}

A History of British Birds. By Wrlliam YARRELI, V.P.L.S., F.Z.S. Fouth Edition, Revised and Enlarged, to the end of Volume 2, by Alfred Newton, M.A., F.R:S., Prufessor of Zoology and Comparative Anatomy in the University of Cambridge, \&c. Continued by Howard SaUnders, F.L.S., F.Z.S., \&c. 4 vols., Svo, cloth, with 564 Wood Engravings, f4$_{4}$. Supplements to the First and Second Editions are still on sale.

A Handbook of British Birds. Showing the Distribution of the Resident and Migratory Birds in the British Islands, with an Index to the Records of the Rarer Species. By J. E. HARTING, F.L.S., \&c. 8vo, 7s. 6d.

Coloured Illustrations of the Eggs of British Birds, with Descriptions of their Nests and Nidification. By Wilziam C. Hewitson. Third Edition, 2 vols., 8vo, 24 I 4 s. 6d.

British Birds, systematically arranged in Five Tables, showing the Comparative Distribution and Periodical Migrations, and giving an Outline of the Geographical Range of 376 Species. By G. PETER Mloore, F.L.S., Captain R.S.L.M., late 3rd Hussars. Folio, sewed, 5s. ; cloth, 7s. 6d.

A List of British Birds, compiled l'y a Committee of the British Onithologists' Union. Sro, sewed, 229 pages, with Index of Synonyms, 10s. 6d.

The Birds of Norfolls. By Henry Stevenson, F.L.S. Vols. I and 2, 8vo, each IOs. 6d.; Vol. 3 in preparation.

The Birds of Middlesex. A Cintrilution to the Natural History of the County. Ty. J. E. HARTINo, F.L.S., F.Z.S. Post 8vo, 7s. 6d.

The Birds of Somersetshire. By Cecil Smitir, of Lydeard House, near Taunton. P'ost 8vo, 7s. 6d.

The Birds of the Fumber District. Iy Jurn Cokntilx, of Great Cotes, Ulecby. Pust Svo, G4.

The Birds of Egypt. By G. Ernest Sireliey, F.Z.S., F.R.G.S., \&c., late Captain Grenadier Gunrds. Royal Svo, with fourteen Coloured Plates, £I IIs. 6d.

A List of the Diurnal Birds of Prey, with keferences and Anmotations; also a Recurl of Specimens preserved in the Norfolk and Norwich Museum. By John Henry Gurney, 8vo, paper covers, 45. 6d. ; cloth, 5s.

A Descriptive Catalogue of the Raptorial Birds in the Norfolk and INorwich Museum. By Join IIENRY GURNeY, Part I., royal Sro, 5 s.

Falconry in the British Isles. By Messrs. Salvin and Brodrick. Second Edition, with New Plates and Additions. Imperial 8vo, $£ 225$.

Falconer's Favourites. By W. Broprick. A series of Life-sized Coloured Portraits of all the British Species of Falcons at present used in Falconry. Large folio, cloth, $£ 22 \mathrm{~s}$.

Falconry in the Valley of the Indus. By R. F. Luktox. Put Sro, with Four Illustrations, 6;.

Hints on Shore-Shooting, incluling a Chapter on Skinning and Preserving lirds. Iy J. E. IIARTiNa, F.L.S., F.Z.S. Post Svo, 3s. 6d.

Autumns on the Spey. By A. E. Krox, M.A. Post Svo, with Four Illustrations by Worf of Fishing and Shooting Adventures. 6s.

The Game Laws of England for Gamekeepers. By IHGI NEvilie, M.A, of the Inner Temple, Esq., Barrister-at-law. A New and Improved Edition. Foolscap 8vo, cloth, 2s. 6d.

Gilbert White's Natural History and Antiquities of Selborne. Edited by Tiroms BeLL, F. R.S., F.L.S., F.G.S., \&c., Professor of Zoology in King's College, London, 2 vols, 8vo, with Steel Plate and other Illustrations, fi I Is. 6d.

The Ornithology of Shalsespeare, Critically Examined, Explained, and Illustrated, liy J. F. IIARTiNG, F.L.S., F.Z.S. 8vo, I2s. 6d.

\section{JOHN VAN VOORST, 1, PATERNOSTER ROW.}




